Universidade de Brasília

Instituto de Ciências Humanas

Departamento de Geografia

Programa de Pós-Graduação em Geografia

UNIVERSIDADE DE BRASÍLIA

PÓS-GRADUAÇÃO EM GEOGRAFIA

O USO CORPORATIVO DO TERRITÓRIO PELO AGRONEGÓCIO E A QUESTÃO

DA LOGÍSTICA DE TRANSPORTES EM MATO GROSSO

Ronei Coelho de Lima

Tese de Doutorado

Brasília-DF: Outubro/2015 
Universidade de Brasília

Instituto de Ciências Humanas

Departamento de Geografia

Programa de Pós-Graduação em Geografia

UNIVERSIDADE DE BRASÍLIA

PÓS-GRADUAÇÃO EM GEOGRAFIA

O USO CORPORATIVO DO TERRITÓRIO PELO AGRONEGÓCIO E A QUESTÃO DA LOGÍSTICA DE TRANSPORTES EM MATO GROSSO

Ronei Coelho de Lima

Orientadora: Prof. ${ }^{a}$ Dr. ${ }^{a}$ Nelba Azevedo Penna

Tese de Doutorado

Brasília-DF: Outubro/2015 
Ficha catalográfica elaborada automaticamente,

com os dados fornecidos pelo(a) autor(a)

LL732u

Lima, Ronei Coelho de

o uso corporativo do território pelo agronegócio e a questão da logística de transportes em Mato Grosso / Ronei Coelho de Lima; orientador Nelba Azevedo Penna. -- Brasilia, 2015. $278 \mathrm{p}$.

Tese (Doutorado - Doutorado em Geografia) -Universidade de Brasilia, 2015.

1. Território. 2. Reestruturação. 3. Agronegócio. 4 Logistica de transportes. I. Penna, Nelba Azevedo, orient. II. Título. 


\title{
O USO CORPORATIVO DO TERRITÓRIO PELO AGRONEGÓCIO E A QUESTÃO DA LOGÍSTICA DE TRANSPORTES EM MATO GROSSO
}

\author{
Ronei Coelho de Lima
}

Tese de Doutorado submetida ao Departamento de Geografia da Universidade de Brasília, como parte dos requisitos necessários para a obtenção do Grau de Doutor em Geografia, área de concentração Gestão Ambiental e Territorial.

Aprovado por:

Prof. a Dr. ${ }^{a}$ Nelba Azevedo Penna, (UnB)

Orientador

Prof. Dr. Fernando Luiz Araújo Sobrinho, (UnB)

Examinador Interno

Prof. Dr. Juscelino Eudâmidas Bezerra, (UnB)

Examinador Interno

Prof. Dr. Jorge Luiz Gomes Monteiro, (UFMT)

Examinador Externo

Prof. Dr. Marcelo Cervo Chelotti (UFU)

Examinador Externo

Prof. ${ }^{a}$ Dr. ${ }^{\text {a }}$ Gloria Maria Vargas Lopes de Mesa, (UnB)

Suplente 
Dedico essa tese:

À minha amada esposa, Ana Lúcia, companheira em todos os momentos...

Aos meus pais, Adelmar e Maria, pela vida, pelo amor e pelos estudos a mim proporcionados...

Aos meus irmãos, Beto e Delma, pela força e carinho... 


\section{AGRADECIMENTOS}

Muitos foram os envolvidos na realização dessa etapa da minha vida, agradeço a todos que de alguma forma contribuíram para que o Doutorado em Geografia se tornasse uma realidade. Agradeço, principalmente:

A Deus pela força nos momentos difíceis;

A minha orientadora, Prof. ${ }^{a}$ Dr. ${ }^{a}$ Nelba Azevedo Penna, por acreditar na minha capacidade e me aceitar como orientando, pelas aulas, críticas, sugestões, enfim, pela orientação precisa, sem a qual essa tese não se realizaria;

A UFMT por me conceder a licença para capacitação, em especial aos servidores da PROPG que sempre foram atenciosos comigo;

Aos professores e amigos da UFMT, Jorge, Antônia Marília e Mirian que estiveram mais próximos e me fortaleceram para a realização da tese;

Aos colegas do Departamento de Geografia do Campus de Rondonópolis por cobrirem meus encargos e por apoiarem minha saída para capacitação;

Aos professores Fernando Luiz, Lúcia Cony, Marília Peluso, Júlio Suzuki e Gloria Maria que ministraram as disciplinas do programa, cujos ensinamentos muito contribuíram para a realização da tese;

Ao amigo Roberto Pizarro, pelo companheirismo e pelas discussões intelectuais nos anos vividos em Brasília;

Aos colegas do doutorado, com destaque para: Rafael, Gessilda, Michel, Márcio, Demerson, Lara, Marizângela e Violeta, pelos debates nas aulas que muito contribuíram para a minha caminhada intelectual e para o Francisco, do IBGE, pelos recursos cartográficos disponibilizados;

Ao amigo José Beda, companheiro na pesquisa de campo em Mato Grosso;

Aos servidores da UnB, Jorge, Jorginho, Simoni e Agnelo, que sempre colaboraram comigo na realização dos trâmites burocráticos;

Aos funcionários da ATC e ALL que forneceram informações importantes para a pesquisa; Aos anônimos que de uma forma ou de outra contribuíram na construção da tese. 


\section{RESUMO}

A reestruturação territorial decorrente dos ajustes espaciais do capitalismo favoreceu a consolidação do agronegócio em Mato Grosso, criando um quadro de uso corporativo do território. A modernização do setor agropecuário implicou na ampliação da produção e na necessidade de uma maior fluidez corporativa, exigindo investimentos no setor de transportes. Porém, como o Estado teve pouca capacidade de dotar o território da logística de transportes adequada aos interesses corporativos, criou-se um quadro que prejudica a competitividade do agronegócio mato-grossense, levando-o a buscar novas alternativas para superar os obstáculos existentes. Nesse contexto, objetivamos compreender os processos advindos dos ajustes espaciais do capitalismo sobre o território para o seu uso corporativo pelo agronegócio, cuja dinâmica produz uma diferenciação territorial quanto às infraestruturas instaladas, gerando um quadro de desenvolvimento pontual em lugares escolhidos pelos agentes hegemônicos.

Palavras-Chave: Território, reestruturação, agronegócio, logística de transportes 


\begin{abstract}
The territorial restructuring resulting from capitalist spatial adjustments favored the agribusiness consolidation in Mato Grosso, creating a corporate use of the territory. The modernization of the agricultural sector resulted in the expansion of production and the need for greater corporate fluidity, requiring investments in the transportation sector. However, as the state had limited capacity to provide the territory with the appropriate transport logistics to corporate interests, a framework that undermines the competitiveness of Mato Grosso agribusiness was created, leading it to seek new alternatives to overcome the hurdles. In this context, we aim to understand the processes arising from spatial adjustments of capitalism over the territory for its corporate use by the agribusiness sector, whose dynamics produces a territorial differentiation regarding the infrastructure installed, generating a timely development framework in places chosen by hegemonic agents.
\end{abstract}

Keywords: Territory, restructuring, agribusiness, transportation logistics 


\section{LISTA DE FIGURAS}

Figura 1 - Áreas de abrangência de programas federais selecionados.................................76

Figura 2 - Vetores logísticos da organização espacial brasileira...........................................95

Figura 3 - Circuito espacial da produção de carne bovina em Mato Grosso..........................119

Figura 4 - Instalações do Porto Seco em Cuiabá-MT............................................................130

Figura 5 - Instalações da Redex (Brado Logística) em Rondonópolis..................................131

Figura 6 - Rodovia BR-163/BR-364 no município de Diamantino-MT...............................135

Figura 7 - Protesto de sitiantes em Rondonópolis contra a cobrança na

praça de pedágio de Rondonópolis-MT..............................................................143

Figura 8 - Fluxos materiais e imateriais entre as tradings $e$ a ALLMN..............................172

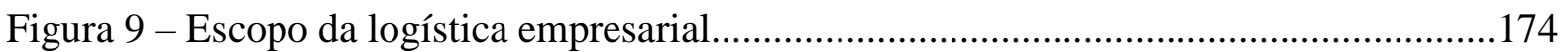

Figura 10 - Localização de áreas industriais em Rondonópolis em 2014.............................186

Figura 11 - Instalações no terminal da ALLMN em Rondonópolis

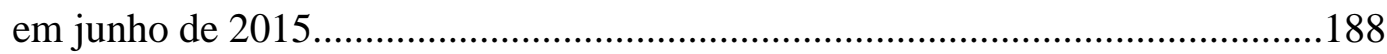

Figura 12 - Sistema de funcionamento da agroindústria nos eixos....................................195

Figura 13 - Terminais de grãos de Cáceres........................................................................213

Figura 14 - Cartograma da evolução da produção de soja em

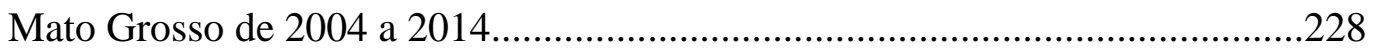

Figura 15 - Vista aérea de cidades voltadas ao agronegócio..............................................243

Figura 16 - Cartograma da evolução do IDHM dos municípios de Mato Grosso...................253

\section{LISTA DE GRÁFICOS}

Gráfico 1 - Mato Grosso: Evolução da Exportação de Produtos

Selecionados de 2009 a 2014

Gráfico 2 - Evolução das exportações de municípios selecionados

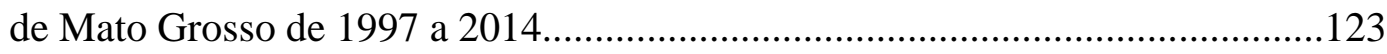

Gráfico 3 - Saldo comercial de Mato Grosso no período de 1998-2014...............................126

Gráfico 4 - Evolução do PIB de Alto Taquari de 1999 a 2012 ...............................................175

Gráfico 5 - Evolução do PIB de Alto Araguaia de 1999 a 2012 ..........................................176

Gráfico 6 - Evolução dos principais segmentos do PRODEIC de 2007 a 2013 .....................182 
Gráfico 7 - Evolução do PIB industrial do Eixo da Área Concentrada da Indústria de 1999 a 2012

Gráfico 8 - Evolução do PIB industrial do Eixo da BR-163

Médio-Norte de 1999 a 2012

Gráfico 9 - Evolução do PIB industrial dos Eixos da BR-070 Leste, da BR-364 Oeste e BR-364/ALLMN de 1999 a 2012

\section{LISTA DE MAPAS}

Mapa 1 - Rodovias de penetração e de apoio que atravessam a região Centro-Oeste.

Mapa 2 - Hidrovias prioritárias para a região Centro-Oeste. .99

Mapa 3 - Mato Grosso: rebanho bovino em 2013 e frigoríficos em 2014.

Mapa 4 - Capacidade de Armazenagem Estática de Mato Grosso em 2014.

Mapa 5 - Estrutura do modal rodoviário em Mato Grosso em 2015

Mapa 6 - MT-322/BR-080

Mapa 7 - BR-242 e Ferrovia de Integração do Centro-Oeste (FICO): novas rotas da produção.

Mapa 8 - Trecho da BR-163 concedido à iniciativa privada

Mapa 9 - Concentração espacial da produção industrial de 2012 em municípios selecionados de Mato Grosso e a produção de soja no estado em 2014.

Mapa 10 - Gargalos do setor rodoviário em Mato Grosso em 2011 203

Mapa 11 - Ferrovia ALLMN/ALLMP e o gargalo ferroviário .206

Mapa 12 - Hidrovia do Paraguai em Mato Grosso e as rotas projetadas pelo agronegócio

Mapa 13 - Novas dinâmicas territoriais do agronegócio em Mato Grosso...........................217

Mapa 14 - A logística de transportes do agronegócio mato-grossense................................219

Mapa 15 - Evolução do processo de municipalização de Mato Grosso.................................227

Mapa 16 - Taxa de domicílios alugados em Mato Grosso em 2010..................................246

Mapa 17 - Os vinte maiores produtores de soja de Mato Grosso em 2014.........................251 


\section{LISTA DE QUADROS}

Quadro 1 - Sistemas do transporte rodoviário do Centro-Oeste em 1970.............................68

Quadro 2 - PLADESCO compatibilizado com as metas nacionais........................................71

Quadro 3 - Projetos do modal rodoviário para a região Centro-Oeste....................................97

Quadro 4 - Projetos do modal hidroviário para a região Centro-Oeste....................................98

Quadro 5 - Projetos do modal ferroviário para a região Centro-Oeste....................................98

Quadro 6 - Frigoríficos de carne bovina em Mato Grosso com registro

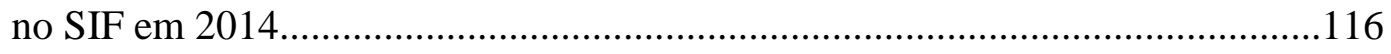

Quadro 7 - Capacidade Instalada de Processamento de Oleaginosas

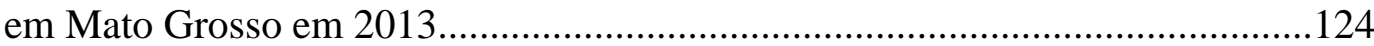

Quadro 8 - Concessões do Sistema Ferroviário Nacional em 2013 .....................................160

Quadro 9 - Aditivos do contrato de concessão da Ferrovia ALLMN...................................167

Quadro 10 - Características dos terminais da ALLMN em Mato Grosso.............................170

Quadro 11 - Usinas Hidrelétricas selecionadas nas bacias dos rios Teles

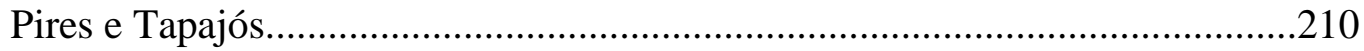

Quadro 12 - Intervenções e custos da hidrovia do rio Paraguai em Mato

Grosso e Mato Grosso do Sul.............................................................................212

Quadro 13 - Dados gerais dos 20 maiores produtores de soja de Mato

Grosso em 2014

Quadro 14 - IDHM de municípios selecionados de Mato Grosso. .254

\section{LISTA DE TABELAS}

Tabela 1 - Área dos estabelecimentos agropecuários recenseados na região Centro-Oeste de 1970 a 2006

Tabela 2 - Produção e vendas dos maiores produtos e serviços industriais com participação de Mato Grosso em 2011

Tabela 3 - Exportações do estado de Mato Grosso de 1998 a 2014

Tabela 4 - Importações do estado de Mato Grosso de 1998 a 2014

Tabela 5 - Capacidade estática de armazenagem de municípios selecionados de Mato Grosso em 2014 
Tabela 6 - Renúncia fiscal no Estado de Mato Grosso de 2007 a 2013.

Tabela 7 - Condição do domicílio de municípios selecionados de Mato Grosso em 2010

Tabela 8 - Evolução da população de municípios selecionados de

Mato Grosso de 1991 a 2010.

\section{LISTA DE ABREVIATURAS E SIGLAS}

ABIOVE - Associação Brasileira das Indústrias de Óleos Vegetais

ANTT - Agência Nacional de Transportes Terrestres

ALL - América Latina Logística

ALLMN - América Latina Logística Malha Norte

ALLMO - América Latina logística Malha Oeste S.A.

ALLMP - América Latina Logística Malha Paulista S.A.

ALLMS - América Latina Logística Malha Sul S.A.

ADM - Archer Daniels Midland

ABIEC - Associação Brasileira das Indústrias Exportadoras de Carne

ANTF - Associação Nacional dos Transportadores Ferroviários

ANUT - Associação Nacional dos Usuários do Transporte de Carga

AEP - Aumento da Eficiência Produtiva em Áreas Consolidadas

ATC - Associação dos Transportadores de Cargas

BNDES - Banco Nacional de Desenvolvimento Econômico e Social

BR - Rodovia federal

CPAC - Centro de Pesquisa Agropecuária do Cerrado 
CONAB - Companhia Nacional de Abastecimento

CNA - Confederação Nacional da Agropecuária

CNI - Confederação Nacional da Indústria

CLT - Consolidação das Leis Trabalhistas

DNIT - Departamento Nacional de Infraestrutura de Transporte

EADI - Estações Aduaneiras do Interior

ENID - Eixos Nacionais de Integração e Desenvolvimento

EMBRAPA - Empresa Brasileira de Pesquisa Agropecuária

EFC - Estrada de Ferro Carajás

EFVM - Estrada de Ferro Vitória a Minas

ETC - Estação de Transbordo de Cargas

EUA - Estados Unidos da América

FAO - Food and Agriculture Organization of the United Nations

FAMATO - Federação da Agricultura e Pecuária do Estado de Mato Grosso

FEMA - Fundação Estadual do Meio Ambiente de Mato Grosso

FERROPASA - Ferronorte Participações S.A.

FERROESTE - Estrada de Ferro Paraná - Oeste S.A.

FCA - Ferrovia Centro-Atlântica S.A.

FICO - Ferrovia de Integração Centro-Oeste

FNSTN - Ferrovia Norte Sul Tramo Norte

FEPASA - Ferrovia Paulista S.A.

FTC - Ferrovia Tereza Cristina S.A.

FERROBAN - Ferrovias Bandeirantes S.A. 
FERRONORTE - Ferrovias Norte Brasil S.A.

FUNAI - Fundação Nacional do Índio

FCO - Fundo Constitucional de Financiamento do Centro-Oeste

FINAM - Fundo de Investimento da Amazônia

GEIPOT - Grupo Executivo de Integração da Política de Transportes

HPP - Hidrovia do Paraguai-Paraná

IBAMA - Instituto Brasileiro do Meio Ambiente e dos Recursos Naturais Renováveis

IBGE - Instituto Brasileiro de Geografia e Estatística

ICMS - Imposto sobre Operações relativas à Circulação de Mercadorias e sobre Prestações de Serviços de Transporte Interestadual e Intermunicipal e de Comunicação

IDHM - Índice de Desenvolvimento Humano Municipal

IPM - Índice de Participação dos Municípios

IDF - Indução ao Desenvolvimento de Áreas de Expansão de Fronteira Agrícola e Mineral

IMEA - Instituto Mato-Grossense de Economia Agropecuária

INPE - Instituto Nacional de Pesquisas Espaciais

IRS - Integração Regional Sul-Americana

JK - Juscelino Kubitschek

LDC - Louis Dreyfus Commodities

MDIC - Ministério do Desenvolvimento, Indústria e Comércio Exterior

MAPA - Ministério da Agricultura, Pecuária e Abastecimento

NPK - Nitrogênio, Fósforo e Potássio

PPP - Parceria Público-Privada

PLADESCO - Plano de Desenvolvimento Econômico-Social do Centro-Oeste 
PIN - Plano de Integração Nacional

PHE - Plano Hidroviário Estratégico

PNLT - Plano Nacional de Logística de Transportes

PPA - Plano Plurianual

PND - Plano Nacional de Desenvolvimento

POF - Pesquisa de Orçamentos Familiares

PIB - Produto Interno Bruto

PAC - Programa de Aceleração do Crescimento

PADAP - Programa de Assentamento Dirigido do Alto Paranaíba

PRODECER - Programa de Cooperação Nipo-Brasileira para o Desenvolvimento dos Cerrados

PCI - Programa de Crédito Integrado

PRODEGRAN - Programa de Desenvolvimento da Região da Grande Dourados

PRODOESTE - Programa de Desenvolvimento do Centro-Oeste

PRODEPAN - Programa de Desenvolvimento do Pantanal

POLOCENTRO - Programa de Desenvolvimento dos Cerrados

PRODEIC - Programa de Desenvolvimento Industrial e Comercial de Mato Grosso

PIL - Programa de Investimentos em Logística

POLAMAZÔNIA - Programa de Polos Agropecuários e Agrominerais da Amazônia

PROTERRA - Programa de Redistribuição de Terras e de Estímulo à Agroindústria do Norte e do Nordeste

PPI - Projeto-Piloto de Investimentos

REDEX - Recinto Especial para Despacho Aduaneiro de Exportação

RFFSA - Rede Ferroviária Federal S.A. 
RDR - Redução de Desigualdades Regionais em Áreas Deprimidas

Secex - Secretaria de Comércio Exterior

SEPLAN-MT - Secretaria de Estado de Planejamento e Coordenação Geral

SESCOOP-MT - Serviço Nacional de Aprendizagem em Cooperativismo no Estado de Mato Grosso

SENAR-MT - Serviço Nacional de Aprendizagem Rural no Estado de Mato Grosso

SIF - Sistema de Inspeção Federal

SIG - Sistema de Informações Geográficas

SUDAM - Superintendência de Desenvolvimento da Amazônia

SUDECO - Superintendência de Desenvolvimento do Centro-Oeste

TIRE - Taxa Interna de Retorno Econômico

TKU -Toneladas por quilômetro útil

TLSA - Transnordestina Logística S.A.

TCE - Tribunal de Contas do Estado

TGG - Terminal de Granéis do Guarujá

TEG - Terminal Exportador do Guarujá

TU - Taxa de Urbanização

UHE - Usina Hidrelétrica

UHT - Ultra High Temperature 


\section{A REORGANIZAÇÃO DO SISTEMA CAPITALISTA E SEUS}

IMPACTOS ESPACIAIS....................................................................................................26

1.1 A REESTRUTURAÇÃO E O USO CORPORATIVO DO TERRITÓRIO.........................36

1.2 UM QUADRO NACIONAL DA REORGANIZAÇÃO DO

SISTEMA CAPITALISTA

2 O ESTADO BRASILEIRO E A REESTRUTURAÇÃO DO TERRITÓRIO.................50

2.1 A DINÂMICA DOS PROCESSOS DE INTEGRAÇÃO E OCUPAÇÃO..........................52

2.2 AS POLÍTICAS TERRITORIAIS COM IMPACTOS NO CENTRO-OESTE

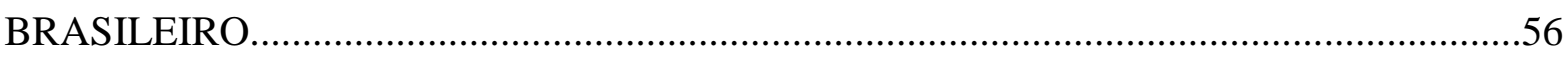

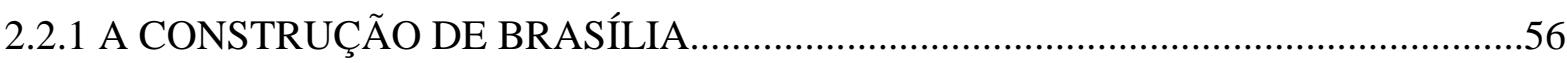

2.2.2 OS PLANOS NACIONAIS DE DESENVOLVIMENTO E OS IMPACTOS TERRITORIAIS.

2.2.3 OS PROGRAMAS ESPECIAIS COM REPERCUSSÕES DIRETAS

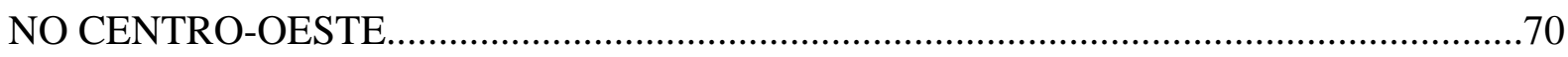

2.2.4 OS EIXOS NACIONAIS DE INTEGRAÇÃO E DESENVOLVIMENTO

(ENID).

2.2.5 O PAC E O PLANO NACIONAL DE LOGÍSTICA DE TRANSPORTES

(PNLT)

\section{LOGÍSTICA E INDÚSTRIA: O USO CORPORATIVO DO}

TERRITÓRIO EM MATO GROSSO.

3.1 OS CIRCUITOS ESPACIAIS DA PRODUÇÃO E OS CÍRCULOS DE

COOPERAÇÃO.

3.2 A LOGÍSTICA DE TRANSPORTES INSTALADA: O MODAL

RODOVIÁRIO.

3.2.1 PROJETOS PRIORITÁRIOS DO MODAL RODOVIÁRIO E

AS CONCESSÕES EM MATO GROSSO

3.3 O NOVO ELEMENTO DA LOGÍSTICA DE TRANSPORTE EM 
MATO GROSSO: A FERROVIA.

3.3.1 A FERROVIA AMÉRICA LATINA LOGÍSTICA MALHA

NORTE (ALLMN) .165

3.4 A RELAÇÃO DA LOGÍSTICA COM A AGROINDÚSTRIA EM MATO

GROSSO E A LÓGICA DA CONCENTRAÇÃO AGROINDUSTRIAL

3.4.1 A QUESTÃO FISCAL COMO ESTRATÉGIA DE ATRAÇÃO.

3.4.2 A INFRESTRUTURA DE TRANSPORTES COMO ESTRATÉGIA

DE ATRAÇÃO.

3.5 A LOGÍSTICA DE TRANSPORTES INCOMPLETA: OS

GARGALOS LOGÍSTICOS .197

3.5.1 MODAL RODOVIÁRIO... .200

3.5.2 MODAL FERROVIÁRIO. .204

3.5.3 MODAL HIDROVIÁRIO. .207

\section{A BASE URBANA DA PRODUÇÃO DO AGRONEGÓCIO}

MATO-GROSSENSE

4.1 A RELAÇÃO ENTRE O URBANO E A PRODUÇÃO DO

AGRONEGÓCIO..

4.2 LUGARES ESCOLHIDOS: CIDADES REFUNCIONALIZADAS E

CIDADES CRIADAS.

4.3 IMPACTOS NO URBANO MATO-GROSSENSE

CONSIDERAÇÕES FINAIS .257

REFERÊNCIAS .263

APÊNDICE. 


\section{INTRODUÇÃO}

Como o capitalismo na busca por uma reprodução ampliada procura novos lugares para realizá-la e nesse processo provoca ajustes espaciais em diversas escalas, o estado de Mato Grosso passa a ser integrado de forma mais incisiva a partir do conjunto de eventos que culminam após 1970, com uma reestruturação do seu território.

Essa reestruturação efetivada pelo Estado busca dois objetivos principais, uma ocupação territorial em consonância com uma integração dos mercados. Os dois objetivos foram alcançados, pois o estabelecimento de um novo modelo produtivo, associado a uma infraestrutura mínima com a qual o território foi equipado, resultou na integração da produção às escalas nacional e internacional, com ênfase para essa última.

Também dinamizou a ocupação do território sob os imperativos capitalistas, gerando conflitos com as populações pré-existentes que se organizavam de maneira diferente (indígenas, posseiros, meeiros), cuja lógica não era compatível com a nova racionalidade baseada na modernização. O arcaico deveria ser superado pelo novo, pelo moderno, pelo racional, em um processo de transição que se dava de acordo com a movimentação da fronteira agrícola, agora tecnificada.

Quanto à infraestrutura disponibilizada ao processo de modernização, necessária para dotar o território das condições favoráveis aos interesses corporativos e sociais, observa-se uma interrupção brusca dos investimentos estatais em virtude da crise fiscal que passou a impor limites na continuidade dos projetos estruturais.

E essa é a gênese da incompletude do processo de reestruturação territorial, cujos rebatimentos serão ampliados posteriormente com o aumento da demanda pelos equipamentos infraestruturais, favorecendo o surgimento dos gargalos que dificultam a fluidez corporativa.

Assim, temos como objetivo geral compreender os processos advindos dos ajustes espaciais do capitalismo sobre o território para o seu uso corporativo pelo agronegócio, por entender que a realidade do estado de Mato Grosso está diretamente relacionada com esses ajustes espaciais.

O trabalho se apoia na seguinte hipótese: 
A reestruturação do território para o seu uso corporativo, efetivada pelo Estado, pode estar relacionada aos ajustes espaciais consoantes com a nova racionalidade globalizada. Por ser desigual, em virtude dos limites impostos ao Estado e em decorrência da dinâmica interna do capitalismo, essa reestruturação resultou na diferenciação interna do território e na gênese dos gargalos logísticos que impedem uma maior fluidez ao setor produtivo em Mato Grosso.

A compreensão do fenômeno, devido a sua complexidade e movimento, se deu com base em três objetivos específicos que guiaram a análise, são eles:

- Identificar o alcance das políticas públicas voltadas à reestruturação do território matogrossense para o seu uso corporativo.

- Caracterizar os impactos gerados em Mato Grosso pela implantação da agricultura tecnificada, indicando as áreas que foram reestruturadas espacialmente para responder às necessidades do agronegócio.

- Analisar a dinâmica da logística de transportes a partir da integração dos modais rodoviário e ferroviário indicando as áreas mais representativas deste processo.

Tendo estabelecido a hipótese e definidos os objetivos, se fez necessário operacionalizar a pesquisa, trazer à tona os procedimentos adotados no projeto de investigação. Como método, foi feito um esforço de análise e síntese, de acordo com as premissas de Lefebvre (1991), dos fenômenos relacionados com o objeto da pesquisa.

Optamos por adotar o território mato-grossense em seu movimento dialético como recorte espacial da pesquisa, com destaque para os municípios de Rondonópolis, Sinop, Sorriso, Lucas do Rio Verde, Nova Mutum, Primavera do Leste e Alto Araguaia. Outros municípios também foram acessados para fortalecer os elementos da análise.

O recorte temporal é representado pelos eventos ocorridos principalmente a partir do final da década de 1970, por ser este o momento em que conjunturas e intencionalidades mais amplas passam a convergir com vistas à operacionalização de novas estratégias do capitalismo e são fundamentais para a consecução do processo de reestruturação territorial. 
Os instrumentos e técnicas utilizadas para a operacionalização da pesquisa foram:

- Levantamento bibliográfico, cujos aportes teóricos e metodológicos guiaram a pesquisa na busca pela apreensão da realidade baseada na relação entre a reestruturação territorial e as repercussões logísticas. Partindo da análise como princípio metodológico, foi feita a decomposição do todo em partes interdependentes, com ênfase para as seguintes questões relacionadas ao objeto de pesquisa:

1 Integração de Mato Grosso com os mercados nacional e internacional;

2 Políticas públicas que reestruturaram o território;

3 Articulação entre a logística associada à produção e a dinâmica de industrialização;

4 Repercussões urbanas oriunda desta dinâmica, principalmente relacionada à refuncionalização e criação de cidades.

- Pesquisa de campo exploratória, efetivada em algumas áreas mais representativas para a pesquisa (redes de circulação: rodoviária e ferroviária; redes de armazenamento e instalações agroindustriais) localizadas no Sul e no Médio-Norte de Mato Grosso.

- Trabalho de campo, realizado ao longo dos principais eixos de escoamento, principalmente as rodovias federais BR-163 e BR-364, e também na BR-070 e nas rodovias estaduais concedidas. Foi feito o registro fotográfico e o levantamento dos trechos rodoviários nodais para o agronegócio com o uso de aparelho de GPS Garmin e-Trex 10, cujos dados foram transcritos para planilhas de campo, contendo coordenadas geográficas, altitude e descrição das condições da via e posteriormente lançadas em planilhas do Excel. O mesmo procedimento foi efetuado em relação à ferrovia América Latina Logística Malha Norte (ALLMN), com ênfase no conjunto de infraestruturas vinculadas ao transporte (terminais) e ao armazenamento que integram o sistema logístico mato-grossense. A produção cartográfica do sistema logístico, industrial e de armazenagem se baseou nesses dados e foram somados às bases cartográficas (a seguir descritas).

- Armazenamento e sistematização das informações (coletadas nas duas fases das atividades de campo - a exploratória e a definitiva), com análise qualitativa da documentação existente (para a elaboração de tabelas, figuras, gráficos, cartogramas, mapas). A utilização de Sistemas de Informações Geográficas (SIGs) foi efetuada com o uso dos programas Envi, GPS TrackMaker e Google Earth que serviram de ferramentas para o tratamento de informações 
referentes a imagens de satélites, bases cartográficas do IBGE e do DNIT, base de dados geomorfométricos do Brasil do Instituto Nacional de Pesquisas Espaciais (INPE) e, para a produção cartográfica referente à produção agrícola, localização de rodovias, ferrovias, armazéns e delimitação de cidades, perímetros urbanos e áreas industriais. Por fim partimos para a análise do conjunto de informações apuradas.

Foram adotados os seguintes passos metodológicos: ajuste do levantamento bibliográfico teórico, metodológico e histórico, com seleção e análise da bibliografia; realização do trabalho de campo (exploratório e definitivo) com observações de áreas selecionadas; produção e tratamento de dados primários a partir das atividades exploratórias e levantamento e crítica dos dados secundários obtidos em órgãos públicos e entidades representativas dos setores investigados; ajuste do projeto a partir dos dados preliminares produzidos, tendo em vista o amadurecimento teórico e prático da proposta de pesquisa; aplicação de entrevistas qualitativas semiestruturadas (junto ao gerente da ALLMN e ao diretor da Associação dos Transportadores de Cargas - ATC); redação dos capítulos resultantes da análise do objeto. Os passos seguiram o cronograma estabelecido perfazendo um período que vai de abril de 2013 até outubro de 2015.

A pesquisa resultou na construção de quatro capítulos que no seu conjunto procuram explicar a questão do uso corporativo do território pelo agronegócio e a questão da logística de transportes em Mato Grosso.

No capítulo 1, temos a fundamentação teórica que discute a reorganização do sistema capitalista e seus impactos espaciais. Partimos da premissa de que a reestruturação do território (SOJA, 1993) deriva de um movimento maior (SANTOS, 1993), que pode ser considerado como movimento de fundo, representado pelos ajustes espaciais do capitalismo (HARVEY, 2006). Resulta desse movimento o desenvolvimento desigual (SMITH, 1988) dos territórios e de áreas de um mesmo território. A relação entre o Estado e o Capital nesse processo é debatida em meio ao atual período de globalização (HARVEY, 1996 e 2004; MANDEL, 1982; SANTOS, 2004; SMITH, 1988; BECKER, 2007; IANNI, 1998).

O uso corporativo do território pelo agronegócio implicou na discussão do conceito de território usado (SANTOS, 2000; SANTOS e SILVEIRA, 2004; SILVEIRA, 2011b) e nas definições acerca do agronegócio (FERNANDES e WELCH, 2008; OLIVEIRA, 2007; CALLADO e CALLADO, 2011). Finalizamos o capítulo com o cenário nacional em meio ao processo de reorganização do sistema capitalista. 
Um maior detalhamento das ações do Estado sobre o território é abordado no capítulo 2, com o tema: O Estado brasileiro e a reestruturação do território. Inicialmente discutimos a dinâmica dos processos de integração e ocupação territorial (BECKER e EGLER, 1993), pois eram essas as bases ideológicas do Estado para justificar as ações impetradas, muitas de caráter pouco justificável (MARTINS, 2003).

Em seguida, a escala é reduzida novamente, pois para tratarmos do nosso objeto tivemos que dar mais ênfase à região Centro-Oeste, porque as politicas não se restringiam às unidades da federação, já que possuíam um caráter regional bastante expressivo.

Esse caráter vai ser refletido nos eventos analisados, cujos destaques são: a construção de Brasília; os Planos Nacionais de Desenvolvimento (I e II PNDs); os programas mais representativos para o Centro-Oeste; a implantação dos Eixos Nacionais de Integração e Desenvolvimento (ENIDs); e finalmente a nova realidade das políticas territoriais, representada pelo Plano Nacional de Logística de Transportes (PNLT) e o Plano de Aceleração do Crescimento (PAC).

Com o capítulo 3, apresentado com o título de: Logística e indústria: o uso corporativo do território em Mato Grosso, aprofundamos a análise e nos posicionamos mais próximos do objeto da pesquisa. Esse é o capítulo que discute a concretude de resultados importantes do processo de reestruturação do território, pois a instalação de fixos diversos relacionados ao setor produtivo e à reprodução social (indústrias, armazéns, novas cidades) está diretamente relacionada com a existência das infraestruturas (transportes, energia e comunicações) disponibilizadas pelo Estado, assim como com a expansão e consolidação da agricultura tecnificada, tornada possível com a intervenção estatal.

Nesse contexto, discutiremos a criação dos circuitos espaciais de produção e dos círculos de cooperação (SANTOS e SILVEIRA, 2004) resultante das novas dinâmicas produtivas, bem como analisaremos a logística de transportes já consolidada, nesse caso representada pelo modal rodoviário que é o sistema de engenharia de transportes hegemônico no Brasil e em Mato Grosso, cujas transformações de base técnica e operacional se efetivam por meio das concessões ao setor privado. O elemento novo que complexifica o fenômeno da logística de transportes voltada ao agronegócio é constituído pela implantação da ferrovia ALLMN no extremo Sul do estado, a partir do ano 2000, e que chega finalmente em Rondonópolis em 2013, potencializando esse município como ponto nodal do agronegócio nacional. 
Após debatermos a condição da logística de transportes existente, buscou-se relacionála com a territorialização das agroindústrias no estado, representada por empresas como a Archer Daniels Midland (ADM), Bunge, Cargill, Louis Dreyfus, Noble, Mosaic e Yara entre outras, que são importantes agentes hegemônicos do capital, pois a espacialização dessas é determinada por algumas condições especiais, como a articulação com os principais eixos de circulação (rodovias e ferrovias), a proximidade com a produção, e a obtenção de vantagens financeiras por meio da isenção de impostos em consonância com programas estaduais de incentivo à industrialização através da renúncia fiscal. Dados estatísticos e o mapeamento das áreas de concentração industrial, afirmam esse pressuposto.

Na sequência é tratada a questão dos gargalos logísticos, apresentando-os como impeditivos da fluidez corporativa pretendida pelos agentes hegemônicos. A análise desse fenômeno é primordial, pois o mesmo reflete a incompletude da reestruturação territorial de base corporativa que entendemos ter havido em Mato Grosso, cuja busca por solução depende de um esforço que se divide em duas frentes. Uma representada pelos novos investimentos nos sistemas de engenharia de transportes que se constitui como parcela técnica e, a outra, na regulamentação de concessões e de novas normatizações para o setor de transportes, como no caso dos portos e das ferrovias, que é a parcela política.

No capítulo 4, partimos para uma discussão acerca das cidades e o seu papel no processo produtivo, cuja densidade técnica passa a exigir um tipo específico de cidade (SANTOS, 2008b). Com o título de: A base urbana da produção do agronegócio matogrossense, discutimos a questão da produção do espaço com ênfase nas relações cidadecampo e a criação e refuncionalização de cidades, destacando a base urbana (DINIZ, 2013) da produção agrícola como síntese do processo.

Como o fenômeno da produção é seletivo em relação aos lugares, trabalhamos os lugares escolhidos que se divide em dois conjuntos, o primeiro é mais restrito em números absolutos e é representado pelas cidades refuncionalizadas - caso de Rondonópolis com a produção (agropecuária e industrial) e com maior densidade quanto à logística de transporte; e de Alto Araguaia com os desdobramentos do terminal da América Latina Logística (ALL), esses desdobramentos nos levou também a incluir informações sobre Alto Taquari e Itiquira. O segundo conjunto de lugares é mais amplo, e foi denominado como cidades criadas, mas aqui também há uma seleção. Pois 107 novos municípios foram criados após 1970, mas os escolhidos, ou criados com estreita relação com o agronegócio e cumprindo função relevante 
de suporte são poucos. Destacamos os mais representativos no texto, caso de Sinop, Sorriso, Lucas do Rio Verde e Primavera do Leste.

A discussão dos impactos no urbano mato-grossense se baseia em dados acerca de algumas condições de reprodução social que ocorre nas cidades, com destaque para aquelas mais representativas. A questão do maior controle do solo urbano, principalmente nas cidades onde o agronegócio é mais estruturado, é preliminarmente discutida.

Esse controle reflete diretamente no acesso à moradia, implicando em maiores entraves para a permanência das populações mais pobres que, mesmo não sendo acolhidas, são fundamentais para a reprodução capitalista como parte da mão de obra menos qualificada que ainda se impõe na divisão do trabalho.

Finalizamos discutindo os dados do Índice de Desenvolvimento Humano Municipal (IDHM), sua evolução e os municípios de maior destaque no ranking, tendo claro que o aspecto generalizador do índice promove distorções, mas como o mesmo é utilizado na ideologia do agronegócio, fizemos um exercício comparativo com outras variáveis que foram trabalhadas no decorrer da pesquisa para verificarmos possíveis convergências. $E$ as convergências de fato foram constatadas.

Nas considerações finais discutimos os resultados das análises efetuadas em sua transitoriedade, visto a continuidade do movimento de reestruturação do território que ainda se encontra em curso. A realidade revelada por meio dos processos investigativos nos aproxima do fenômeno de corporatização do território, que fora efetivado para atender, no seu conjunto, os interesses dos agentes hegemônicos do agronegócio, cuja necessidade de articulação com os diversos mercados, notadamente externos, eleva a importância da logística de transportes existente e projetada como elemento fundamental para a fluidez corporativa. 


\section{A REORGANIZAÇÃO DO SISTEMA CAPITALISTA E SEUS IMPACTOS ESPACIAIS}

A reestruturação territorial surge dos ajustes espaciais do capitalismo em seu movimento constante de reprodução, que demanda mudanças frente às novas racionalidades que se impõem. Essas mudanças são normalmente gestadas para atender os interesses de um conjunto de agentes hegemônicos que buscam dotar o território das condições ideais para a consecução dos seus projetos.

Tendo em vista a ampliação constante do movimento do capital financeiro e produtivo, possibilitado pelos avanços dos sistemas técnicos e informacionais atualmente disponíveis, os territórios são acessados para usos específicos. E, para atender a tais usos, são reestruturados para se adequarem a certas lógicas por vezes estranhas aos lugares onde se dão, pois muitas ações são extrovertidas e pouco preocupadas com o seu entorno imediato. Mas, a consecução dos projetos do capitalismo em sua dinâmica prescinde dos territórios.

Para Santos (2008a, p. 338) a realização, dos projetos, só se dá nos territórios, pois “[...] o território termina por ser a grande mediação entre o Mundo e a sociedade nacional e local, já que, em sua funcionalização, o 'Mundo' necessita da mediação dos lugares, segundo as virtualidades destes usos específicos.”. Nesse processo há uma modificação do conjunto dos lugares, logo do espaço como um todo, visto que nem todos os lugares são escolhidos.

Enquanto mediador do local com o mundo, o território em seu processo de reestruturação sofre diversas alterações em suas dinâmicas internas, que também são externas, visto comporem um todo, possibilitando a criação do novo, que parte do velho em uma ação dialética constante.

Dessa forma, a produção do espaço, enquanto produção social, é forjada pela fricção dos opostos, cuja convivência e constante superação se tornam os dínamos desse processo de produção. No entanto, algumas ações que são impostas ao território terminam por provocar modificações mais amplas e profundas, causando alterações que podem ser consideradas estruturais.

Para Soja (1993, p.193): 
A reestruturação, em seu sentido mais amplo, transmite a noção de uma "freada", senão de uma ruptura nas tendências seculares, e de uma mudança em direção a uma ordem e uma configuração significativamente diferentes da vida social, econômica e política. Evoca, pois, uma combinação sequencial de desmoronamento e reconstrução, de desconstrução e tentativa de reconstituição, proveniente de algumas deficiências ou perturbações nos sistemas de pensamento e ação aceitos.

Esse movimento gerado pelas tensões entre o que está estabelecido e o que busca estabelecer-se resulta da dinâmica interna das relações sociais, e assim, a compreensão dessas relações demanda compreender os movimentos mais amplos, cujas dinâmicas produzem o espaço ininterruptamente.

Dessa forma, devemos buscar os elementos constituintes das transições dos modos de produções, visto que esses promovem no seu processo evolutivo alterações profundas na sociedade e na sua forma de organização espacial.

Santos (1993, p. 113) ao discutir o espaço como sendo o maior conjunto de objetos, aponta que estes possuem idades diversas, mas que são movidos e vivificados por uma lei maior e única. Esta lei submete as relações sociais, pois "Trata-se de uma grande lei dos movimentos de fundo, dada pelos modos de produção e seus momentos, responsável pelas mudanças grandes [...].”.

A reestruturação territorial está diretamente relacionada com as dinâmicas do modo de produção capitalista, pois o movimento de ajuste espacial empreendido no território decorre das necessidades do capital em seu processo de expansão. Segundo Harvey (2006, p. 117) no processo de expansão pode haver a exportação de capital para produção para resolver o excesso de capital excedente, pois o emprego desse capital em condições de alto retorno permite arrefecer, temporariamente, as crises surgidas no interior do capitalismo, mas essas crises "[...] são fases de intensa racionalização na transformação e expansão geográfica. A dialética interna da sociedade civil é perpetuamente mitigada e reproduzida mediante o recurso constante ao ajuste espacial.".

Assim, esse processo de expansão resulta das contradições internas do capitalismo gerador das próprias crises do sistema - na busca por uma reprodução contínua e ampliada do capital e que gera um desenvolvimento desigual, que segundo Poulantzas (2000, p. 93) é uma “[...] característica do capitalismo desde seus inícios.”. 
Em meio à discussão sobre a lógica do desenvolvimento desigual, Smith (1988, p. 19) faz a seguinte consideração:

\begin{abstract}
A lógica do desenvolvimento desigual deriva especificamente das tendências opostas, inerentes ao capital, para diferenciação, mas com a simultânea igualização dos níveis e condições da produção. O capital é continuamente investido no ambiente construído com o fito de se produzir mais-valia e expansão da base do próprio capital. Mas, da mesma forma, o capital é continuamente retirado do ambiente construído de forma que ele possa se deslocar para outra parte e se beneficiar com taxas de lucro mais altas. A imobilização espacial do capital produtivo em sua forma material não é nem menos necessária do que a perpétua circulação do capital como valor. Assim, é possível ver o desenvolvimento desigual do capitalismo como a expressão geográfica da contradição mais fundamental entre o valor de uso e valor de troca. O padrão que resulta na paisagem é bem conhecido: desenvolvimento de um lado e subdesenvolvimento de outro.
\end{abstract}

Como processo geral, esse movimento é internalizado nas diferentes formações econômicas, friccionando com a realidade interna, mas mantendo sua essência de busca por uma reprodução ampliada. Nesse contexto, a expansão do capitalismo no Brasil reproduz a tendência do capital de expansão geográfica que produz as desigualdades espaciais. Ao discutir a expansão do capitalismo no Brasil, Rossini (1986, p. 108) argumenta que a produção do espaço brasileiro é realizada a partir do foco de acumulação situado espacialmente no Sudeste e tendo São Paulo no comando do processo. Em sua dinâmica observa-se o movimento dialético de criação e destruição que é consoante com um processo produtivo global de caráter espacial e produtivo. Temos então que,

[...] a destruição das economias regionais nada mais é do que a forma de reprodução e desenvolvimento do sistema em escala nacional. Assim, se articula um processo de produção geral do espaço que se realiza de maneira desigual, pelo movimento diferencial do processo de acumulação." (ROSSINI, op. cit., p. 108).

A reestruturação inerente aos processos de ajustes do capital pode ocorrer com intensidades diferentes, podendo ser mais profunda e estrutural, bem como ser localizada e conjuntural, mas apresenta os elementos de mudanças implícitos na sua dinâmica e, por ser uma produção social, está imersa na incerteza dos seus resultados. 
Nesse sentido, Soja (1993, p. 194) deixa claro que na reestruturação não há uma predeterminação das possibilidades e resultados potenciais, visto não ser um processo "mecânico ou automático", pois:

Em sua hierarquia de manifestações, a reestruturação deve ser considerada originária de e reativa a graves choques nas situações e práticas sociais preexistentes, e desencadeadora de uma intensificação de lutas competitivas pelo controle das forças que configuram a vida material. Assim, ela implica fluxo e transição, posturas ofensivas e defensivas, e uma mescla complexa e irresoluta de continuidade e mudança.

Pouco previsível em sua essência, a reestruturação demanda acordos entre os agentes hegemônicos que representam o local, o território envolvido nas ações, e os agentes hegemônicos detentores do capital - podendo ser esses agentes nacionais ou estrangeiros - e que buscam nos lugares satisfazer suas necessidades de acumulação. As grandes corporações adotam ações expansionistas com vistas à manutenção da competitividade, visto que o capital ao se mundializar amplia a escala da concorrência com outros capitais. Logo, resulta dessa condição as estratégias que levam a um novo quadro.

Ao tratar da mundialização do capital, Chesnais (1996, p. 17) a considera como:

[...] a capacidade estratégica de todo grande grupo oligopolista, voltado para a produção manufatureira ou para as principais atividades de serviços, de adotar, por conta própria, um enfoque e conduta "globais".

O autor entende que em virtude da intensificação da competição capitalista foi desencadeado um processo de oligopolização, em que temos uma ampliação das ações das grandes corporações industriais, comerciais e financeiras, implicando na mundialização mais efetiva do capital.

Os capitais disponíveis para investimentos deixam as tradicionais áreas que recebiam esses recursos, principalmente os países da tríade - Estados Unidos, Japão e Europa (CHESNAIS, 1996) - e se deslocam para outras áreas. São capitais de diversas naturezas, desde as grandes corporações até capitais individuais. 
Nesse sentido, Harvey (2004, p. 83) argumenta que os capitalistas individuais procuravam investimentos vantajosos, pois assim, "O capital excedente de um lugar pode encontrar emprego noutro lugar em que as oportunidades de lucro ainda não foram exauridas.".

Os capitais dos países da tríade, que buscavam aplicações vantajosas, encontraram em países como o Brasil uma demanda por crédito para consolidar o processo de criação de infraestruturas diversas (nos setores de transporte, energia e comunicações) e para expandir um modelo produtivo já existente nas regiões Sul e Sudeste. O processo de reestruturação efetuado no Brasil buscou dotar a região Centro-Oeste das condições para que essa se tornasse o celeiro do país e grande produtor mundial de commodities.

A movimentação de capitais busca novas áreas de investimentos exatamente porque suas tradicionais áreas de investimentos apresentavam limites para a reprodução do capital nos níveis esperados. As mudanças produtivas e de organização no interior do capitalismo, em meio às crises que se formaram a partir da década de 1970, (STORPER, 1991), (HARVEY, 1996), (BENKO, 2002) levaram um conjunto considerável de capitais a buscar novas áreas que pudessem receber os capitais e remunerá-los em níveis satisfatórios.

Em relação ao setor produtivo, Storper (1991) argumenta que emergia a exigência por uma reestruturação e uma reorganização espacial, que ainda está em curso, para superar os limites apresentados pelo sistema produtivo. Benko (2002) explica que em meio à crise o capitalismo passa a demandar toda uma reestruturação necessária para superar uma crise de eficácia e legitimação e uma nova racionalidade é imposta na busca por uma reprodução ampliada do capital. Para isso, novos espaços de produção são criados.

Dessa forma, partimos da premissa de que a reestruturação efetuada no território, que possibilitou a instalação de um novo modelo de produção em áreas até então pouco articuladas do interior do Brasil com os mercados interno e externo, desencadeada principalmente a partir da década de 1970, resultou da ação de dois agentes hegemônicos cujos interesses se mostraram convergentes, pois se de um lado tínhamos um conjunto de capitais ávidos por investimentos rentáveis, do outro tínhamos um governo brasileiro disposto a se endividar para prosseguir com seus projetos de integração e ocupação.

A associação entre o Estado e o Capital - sendo este personificado pelas corporações capitalistas - se deu entre outras razões porque as intencionalidades apresentavam 
convergências, redundando em ações cujos rebatimentos territoriais se propagaram em desdobramentos sociais, econômicos e ambientais de grande monta. Possibilitou-se, no decorrer desse processo, um uso corporativo do território.

O processo se estabelece porque a força do capital em seu movimento de expansão geográfica, empreendido atualmente principalmente pelas grandes corporações, exige do território as condições ideais para que: o processo produtivo se realize plenamente; que o capital financeiro não encontre barreiras; e que o mercado consumidor e o mercado de trabalho possam ser controlados minimamente.

Para isso contam com um mediador importante, representado pelo Estado, que se equilibra para atender as exigências corporativistas e "criar um bom clima de negócios" (HARVEY, 1996, p. 160) e ao mesmo tempo responder a demandas sociais mais amplas. Como os interesses corporativos são atomizados, cabe ao Estado disponibilizar as condições ideais para a manutenção do modo de produção capitalista.

Nesse sentido, partindo do pensamento de Kautsky, que propõe ser a classe capitalista aquela que reina, mas não governa, e que a seu turno se resigna a apenas dar ordens ao Governo, Mandel (1982, p. 336) conclui:

\begin{abstract}
A concorrência capitalista determina assim, inevitavelmente, uma tendência à autonomização do aparato estatal, de maneira que possa funcionar como um "capitalista total ideal", servindo aos interesses de proteção, consolidação e expansão do modo de produção capitalista como um todo, acima e ao contrário dos interesses conflitantes do "capitalista total real" constituído pelos "muitos capitais" do mundo real.
\end{abstract}

De fato, o Estado é essencial para o capitalismo, e Harvey (2004, p. 107) assim o comprova: "É importante reconhecer o papel mediador fundamental das estruturas e dos poderes financeiros e institucionais (particularmente o Estado) nos processos de acumulação do capital.".

Já Santos (2004, p. 19) desconstrói a premissa de morte do Estado, pois acredita que estejamos diante do seu fortalecimento "[...] para atender aos reclamos da finança e de outros grandes interesses internacionais, em detrimento dos cuidados com as populações cuja vida se torna mais difícil.". 
Concordando com a manutenção do Estado enquanto mediador importante e discutindo a relação entre esse e o capital global, Benko (2002, p. 47) conclui que:

\begin{abstract}
Assim as políticas do Estado nacional, da fiscalidade à gestão monetária [...] sofrem e injetam ao mesmo tempo o ponto de vista internacional nos processos domésticos de decisão. [...] é inexato falar de "enfraquecimento" do Estado no momento em que a mundialização conota implicação mais direta e caráter de classe mais decisivo do Estado Nacional.
\end{abstract}

A criação de normas, efetuadas no interior de cada Estado, é imprescindível para a manutenção dos fluxos gerados pelas ações empreendidas pelo capital global, sejam por meio de investimentos externos diretos (CHESNAIS, 1996) ou pelos capitais especulativos.

Em relação aos investimentos voltados à produção, Smith (1988, p. 205) argumenta que o capital que se imobiliza na paisagem necessita de proteção contra outros capitais, e isto implica a ação do Estado na regulação da reprodução das forças de trabalho, na criação de infraestrutura e leis comerciais, portanto, "O Estado se desenvolve para realizar essas tarefas, assim como para defender o capital militarmente, onde seja necessário.”. Já os capitais especulativos demandam maior liberdade para ações, porém, contraditoriamente, a falta de controle deflagra crises diversas no setor financeiro, como aponta Harvey (2011).

Tratando do papel do Estado no processo de globalização da produção agrícola brasileira, Elias (2003, p. 65) argumenta que "Coube ao Estado brasileiro adequar a produção e o território à reprodução ampliada do capital na agricultura do país." Enfatiza que a modernização empreendida por esse agente permitiu a ascensão de circuitos espaciais de produção e círculos de cooperação globalizados. Nesse ínterim, fixos e fluxos foram expandidos e/ou acrescentados no campo e as condições de articulação foram intensificadas.

Becker (2007, p. 267-268), chama a atenção para a logística das corporações que, inserida no contexto da globalização, impacta diretamente o território e consolida sua reestruturação, afirmando que:

A globalização e a abertura dos mercados impõem novos padrões de competitividade baseada na exportação e na privatização do capital social, numa reestruturação da economia que resulta em maior poder para as 
corporações. A logística permite às corporações gerar em tempo rápido e em ampla escala grandes territórios corporativados que tendem a incorporar, submeter ou excluir os territórios de grupos sociais menos poderosos, e a revigorar a expansão da fronteira agropecuária.

A complexificação dos processos desencadeados no território decorre do atual período em que vivemos - caracterizado entre outros aspectos pela maior articulação, principalmente dos agentes corporativos -, que se soma às benesses disponibilizadas seletivamente pelo desenvolvimento tecnológico e informacional. Esse quadro, por sua vez, favorece o surgimento e o agravamento de crises diversas (econômicas, políticas, ambientais) cujos rebatimentos promovem descontroles nos lugares, implicando negativamente na produção social.

As condições gerais apresentadas compõem um quadro complexo, resultante de um conjunto de eventos que pode ser denominado de globalização, cuja compreensão, mesmo que mais centrada nas condições econômicas, pode nos levar a um entendimento mais profundo dos fenômenos que a cercam, notadamente daqueles com rebatimentos territoriais.

Porto-Gonçalves (2011) mesmo criando uma periodização da globalização, nesse caso da globalização da natureza, argumenta que o processo de globalização pode ter o seu início marcado, apesar das divergências, a partir de 1970, tendo como uma das principais características o aumento do protagonismo do capital financeiro, após a quebra do contrato de Bretton Woods.

Haesbaert e Limonad (2007, p. 40) chamam a atenção para a ideia de a globalização remeter, equivocadamente, a um processo de homogeneização econômica, espacial e social. $\mathrm{Na}$ verdade a globalização “[...] se processa em pontos seletivamente escolhidos do globo terrestre como, em muitos casos, é obrigada a adaptar-se e/ou a reelaborar processos políticoeconômicos e culturais ao nível local.", assim, a referida homogeneização se daria por níveis, um nível referente ao capital das elites planetárias e outro relacionado à miséria e a pobreza que são acirradas no decurso da globalização.

De acordo com Santos (2004) a globalização pode ser entendida, não de forma exclusiva, como o auge da internacionalização do mundo capitalista que se pauta em dois estados, aquele das técnicas e aquele da política, cujo funcionamento em conjunto não autoriza uma separação para um entendimento unitário. Chama a atenção para o fato de que 
apesar de existir um reconhecido avanço das técnicas, cujo sistema se faz sentir no nível planetário, é necessário considerar as ações que favoreceram a ascensão de um mercado considerado como global que protagoniza os processos políticos mais plenos de realização. Propõe então uma arquitetura da globalização cujos fatores que permitem a sua explicação seriam: “[...] a unicidade da técnica, a convergência dos momentos, a cognoscibilidade do planeta e a existência de um motor único na história, representado pela mais-valia globalizada." (SANTOS, op. cit., p. 24).

Entendida enquanto internacionalização do mundo capitalista, a globalização pressiona as unidades soberanas, representadas pelo Estado-Nação, a colaborar com os projetos de expansão capitalista em todos os níveis e em todos os locais. Na tentativa de se adequarem aos projetos corporativos, o Estado passa a coordenar ações que se afastam das necessidades mais efetivas da sociedade local. O quadro se torna mais dramático com a escassez dos recursos, ou com a elevação dos custos referentes às tomadas de empréstimos. Os projetos nacionais são corrompidos, pois passam a atender interesses exógenos.

Para Ianni (1998, p. 78), “A globalização da economia capitalista, compreendendo a formação dos centros decisórios extra e supranacionais, debilita ou mesmo anula possibilidades de estratégias nacionais.”. Com isso temos uma aceleração dos vínculos externos em condições desiguais, pois os interesses do capital demandam vantagens para as corporações em detrimento das áreas exploradas, enfraquecendo, de certa forma, as relações no interior dos países tendo em vista a emergência das relações externas.

Para Giddens (2006, p. 21) a extrema facilidade de movimento dos fluxos financeiros, pautados na evolução das técnicas informacionais, possibilitou uma predominância do capital financeiro, ainda que o comércio externo - composto de bens e serviços também tenha apresentado elevado crescimento - assim, no atual período de globalização, investidores podem movimentar quantias imensas no toque de um botão e dessa forma, “[...] podem desestabilizar economias que pareciam sólidas como granito [...]”.

Se o setor financeiro encontra na globalização as condições de alavancar lucros por meio da liberdade de investimentos, apesar das crises sucessivas desencadeadas no âmbito do capitalismo, o setor produtivo tradicional, mais rígido, pois necessita imobilizar capital por meio de capital fixo, deve adotar estratégias voltadas a uma flexibilidade de ações e de planejamento. 
Buscando corrigir os problemas decorrentes das crises, houve entre outras estratégias, uma redistribuição corporativa pelo espaço, levando os lugares a disputarem os investimentos, pois a concorrência tornou-se global. Essas disputas estão na gênese do que chamamos de guerra dos lugares, como aponta Santos (2008a), que decorrem da evolução do capitalismo que produz um desenvolvimento desigual, pois como assinala Smith (1988, p. 16) “[...] o desenvolvimento desigual é a expressão geográfica sistemática das contradições inerentes à própria construção e estrutura do capital.”.

Temos então uma reestruturação do setor produtivo para superar uma crise de eficácia e legitimação e uma nova racionalidade é imposta na busca por uma reprodução ampliada do capital. Como as relações de produção se tornam mais complexas, inclusive pela expansão geográfica que toma vulto no processo de desconcentração produtiva, há a necessidade de uma maior sincronia entre as diversas etapas envolvidas.

Dessa forma, a sincronização das etapas de produção, distribuição, circulação (entendida enquanto troca) e consumo permite uma maior agilidade nas diversas etapas do processo em seu conjunto e favorece a reprodução do capital de forma mais efetiva, pois como assevera Marx (2008) essas etapas são interdependentes, e no caso da produção e consumo, são consubstanciadas como seus contrários (produção é consumo e consumo é produção) e mediadas entre si. Da mesma forma, na distribuição e produção, todas as categorias são estabelecidas de dupla maneira, caso do lucro e do juro que figuram enquanto fatores determinantes e formas determinadas da distribuição e também como produção, já que proporciona o aumento de capital. Finalmente temos a circulação (a troca na sua totalidade) mediadora da produção, distribuição e consumo.

Devemos entender, no entanto, que as considerações de Marx se deram em um contexto diferente, pois hoje a maior complexidade dos processos inerentes à produção exige uma análise mais apurada da sua dinâmica. Ao mesmo tempo, observa-se que a lógica de reprodução ampliada do capital, por meio de lucros crescentes, continua sendo a essência do capitalismo.

A expansão geográfica do capitalismo, considerando os interesses das corporações dos países mais desenvolvidos nesse modo de produção, se torna uma alternativa às crises geradas no interior do capitalismo, pois a existência de mercados potenciais nos países periféricos se tornou o fator determinante para a instalação de empresas multinacionais nesses países. Seria então o mercado, cujos arranjos internos permitiriam uma reserva para essas empresas, o 
grande trunfo das novas áreas que se industrializavam no contexto da nova ordem produtiva (LIPIETZ, 1988).

Temos nesse contexto uma fricção do movimento maior, desencadeado nos países centrais por conta das sucessivas crises do capitalismo, com a realidade interna dos países que são atingidos pelas ondas de expansão desse movimento.

Assim, cada nação passa a se estruturar em consonância com os interesses dos agentes hegemônicos, com vistas a buscar alternativas de crescimento econômico e legitimidade política dos regimes instalados, no caso do Brasil, baseado no autoritarismo. Consolida-se um processo de reestruturação territorial com vistas a atender as demandas empresariais, gerando um uso corporativo do território.

É nesse contexto que a região Centro-Oeste tem o seu modelo produtivo reestruturado para atender aos desígnios do Estado no seu projeto maior de ocupação e integração, cujas ações foram articuladas visando o acesso, pelo capitalismo monopolista, ao mercado interno. Da mesma forma, internamente buscava-se o mercado exterior, cujas exportações passaram a representar a redenção para um país que se endividava sistematicamente. Das ações empreendidas, temos a ascensão da agricultura tecnificada, tornada dependente de articulações em escalas que ultrapassam as fronteiras brasileiras. Dos insumos para a produção até a formação de preços dos produtos, o processo produtivo passava a atender um novo mando, externo, cujas ações eram geridas e pensadas pelo mercado internacional. É o ponto de partida para a consolidação do agronegócio na região e especialmente em Mato Grosso.

\subsection{A REESTRUTURAÇÃO E O USO CORPORATIVO DO TERRITÓRIO}

A racionalidade que passa a imperar sob os ajustes espaciais do capitalismo interfere diretamente nas atividades produtivas e exigem uma nova adaptação ou reestruturação do território para atender as novas necessidades impostas. $\mathrm{O}$ movimento transcende os limites territoriais, implicando em alterações significativas da base produtiva em setores diversos, como a agricultura, cuja base torna-se mais técnica e dependente da ciência e da informação, gerando, no entanto, um modelo excludente, na medida em que exige uma maior capitalização dos agentes envolvidos no processo produtivo. 
Cria-se o vínculo entre o território, - não enquanto território em si, mas como território usado (SANTOS e SILVEIRA, 2004) - que exploramos como conceito para analisar o processo de corporatização do território favorecido pelas políticas públicas empreendidas pelo Estado, cuja dinâmica favoreceu um estreitamento de relações entre as diversas regiões brasileiras com vistas ao atendimento dos interesses hegemônicos nacionais e internacionais quanto ao processo produtivo.

O uso corporativo do território passa a ser uma realidade que possui, entre outros problemas, a criação de estratégias que visam satisfazer somente o processo produtivo, sem uma preocupação mais ampla com a sociedade que ocupa este território, pois a sua organização e sua dinâmica são voltadas para fora, em detrimento de arranjos locais.

De acordo com Silveira (2011b, p. 5) o território usado, enquanto espaço concreto do homem, deve ser reconhecido pela sua densidade histórica e pela operação de forças sobre formas que são dinâmicas, produtora de densidades, sendo essas densidades de caráter normativo, informacional e técnico. Considera ainda que:

[...] se as formas são importantes, também o são as ações humanas, isto é, o comportamento no território das pessoas, das instituições, das empresas, determinando um dinamismo que varia segundo sua origem, sua força, sua intencionalidade, seus conflitos. O território usado é assim uma arena onde fatores de todas as ordens, independentemente da sua força, apesar de sua força desigual, contribuem à geração de situações.

As situações geradas decorrem da fricção dos interesses diversos, pois os diversos agentes envolvidos buscam satisfazer as suas necessidades, desejos e interesses, colidindo com os interesses de outros agentes. Cria-se um conjunto complexo de situações cuja mediação é estabelecida por um agente hegemônico, nesse caso o Estado, que como vimos é o mediador entre o local e o global. Como estamos discutindo a produção social em tempos de globalização, essa relação entre as escalas local, nacional e global torna-se mais relevante à medida que exista uma maior articulação entre as escalas.

A concepção de totalidade do conceito de território usado é bastante explícita, na medida em que comporta todos os elementos da sociedade em sua interação dialética com os objetos e com as ações. Para Milton Santos o território usado seria o espaço de todos os 
homens, instituições e empresas. Com essa visão totalizante, a análise pode ser enfrentada de forma mais coerente. $\mathrm{O}$ autor assevera ainda que:

Para os atores hegemônicos o território usado é um recurso, garantia da realização de seus interesses particulares. Desse modo, o rebatimento de suas ações conduz a uma constante adaptação de seu uso, com adição de uma materialidade funcional ao exercício das atividades exógenas ao lugar, aprofundando a divisão social e territorial do trabalho, mediante a seletividade dos investimentos econômicos que gera um uso corporativo do território. (SANTOS, 2000, p. 108).

Os desdobramentos da reestruturação efetivada no campo, com a modernização da base produtiva da agricultura, propiciaram um conjunto de processos cujas dinâmicas oportunizaram aos grandes grupos envolvidos nesse setor econômico as condições ideais para a sua consolidação. Mas como o capitalismo no seu movimento gera as suas próprias crises, os fatos que eclodiram principalmente a partir da década de 1970, no exterior, e cujos rebatimentos mais intensos se fizeram sentir internamente nos anos de 1980, inibiram os investimentos estatais no projeto de reestruturação.

Criou-se, então, no transcurso do processo de reestruturação, uma desaceleração que gerou a imobilização da dinâmica de reestruturação. Assim, as ações públicas sobre o território não puderam acompanhar a evolução do processo produtivo. Daí surge um descompasso que contrariaria o setor produtivo até os dias atuais, incorrendo em pressão constante dos agentes hegemônicos do setor corporativo e o Estado, também agente hegemônico.

As relações entre os agentes hegemônicos são refletidas nos processos produtivos empreendidos no território e se coadunam com o que Elias (2003) entende como sendo os imperativos da ordem global hegemônica cuja dinâmica é fortalecida com a ascensão dos circuitos espaciais produtivos e dos círculos de cooperação, apontados por Santos e Silveira (2004) dentro da divisão territorial do trabalho.

Assim, as verticalidades "[...] pontos no espaço que, separados uns dos outros, asseguram o funcionamento global da sociedade e da economia." se impõem às horizontalidades "[...] extensões formadas de pontos que se agregam sem descontinuidade, [...]" (SANTOS, 2008a, p. 284). Isso ocorre porque enquanto as horizontalidades promovem a 
produção propriamente dita, as verticalidades coordenam os demais momentos da produção (circulação, distribuição, consumo), incorporando uma cooperação ampliada de ações. Com isso as grandes corporações passam a dominar os processos produtivos, impondo uma dinâmica de concentração e centralização que se reflete no território.

Mas, como assevera Santos (2000), não devemos nos esquecer dos agentes hegemonizados, que tem no território o seu abrigo e que lutam pela sobrevivência em meio às ações hegemônicas. Além disso, compõem o mercado de trabalho, elemento que juntamente com os meios de produção promovem o processo produtivo.

Todavia, na dinâmica das ações hegemônicas, criam-se nos territórios pontos modernizados conectados em uma grande rede, como as redes agroindustriais (ELIAS, 2011) organizadas em escala global e que operam por meio das técnicas informacionais disponíveis, criando um arranjo em que os lugares são escolhidos de acordo com a disponibilidade das condições de produção e circulação, já que o consumo dá-se em ampla escala.

A agricultura tecnificada, que é o cerne do agronegócio, é baseada na ciência e na informação e funciona em forma de sistema, pois deixa de representar uma ação isolada, uma produção isolada, para tornar-se parte de um conjunto maior que implica diversas cadeias produtivas a montante e a jusante do processo produtivo em si. Esse conjunto passa a exigir daquele que se integra uma maior densidade de capital para investir na produção tornando o processo excludente.

Mas o que é o agronegócio? Como se estrutura? Quais as suas estratégias?

De acordo com Fernandes e Welch (2008, p. 48) atribui-se a Davis e Goldberg a primeira conceituação do agronegócio, nesse caso do agribusiness, em 1957, quando esses autores afirmavam ser o agronegócio:

[...] um complexo de sistemas que compreende a agricultura, indústria, mercado e finanças. O movimento desse complexo e suas políticas formam um modelo de desenvolvimento econômico controlado por corporações transnacionais, que trabalham com um ou mais commodities e atuam em diversos outros setores da economia. 
A ideia do agronegócio como um sistema é acompanhada por Callado e Callado (2011, p. 1) ao argumentarem que a atual complexidade e diversificação do ambiente econômico e social exige entender a inserção do agronegócio não enquanto um conjunto de atividades isoladas, mas como um "amplo espectro de inter-relações e interdependências produtivas, tecnológicas e mercadológicas.”.

As relações mais amplas se dão tanto a montante quanto a jusante do processo produtivo, levando a um aumento da densidade das técnicas empregadas, da necessidade de inovações, oriundas das ciências voltadas para o desenvolvimento de novos produtos e dependentes da informação, que faz a intermediação do processo. A forma de produzir muda, partimos para as especializações produtivas de culturas específicas denominadas de commodities.

Oliveira (2007, p. 147) argumenta que:

O monocultivo de exportação até então chamado de agribusiness, ganhou sua expressão na língua portuguesa: o agronegócio. [...] tratava-se de distinguir entre a atividade econômica milenar de produção dos alimentos necessários e fundamentais à existência da humanidade, e, a atividade econômica da produção de commodities (mercadorias) para o mercado mundial. Definia-se assim, na prática da produção econômica, uma distinção importante entre a agricultura tipicamente capitalista e a agricultura camponesa.

Ao adotar a monocultura como a base da agricultura moderna, passa-se de uma agricultura orgânica para uma agricultura mecânica e química, o que implica em uma dependência direta da indústria e do financiamento bancário, pois se constitui como subsistema desses setores (PORTO-GONÇALVES, 2011).

Amplamente difundido no Brasil, o termo agronegócio faz parte dos discursos oficiais e da mídia que o apontam como alternativa para o crescimento e a integração com os mercados mundiais. Nesse sentido, está em consonância com os preceitos da globalização, pois estabelece uma conexão direta do local, onde se dá a produção, com o global, constituído pelo mercado que se vincula com os agentes hegemônicos.

Alinha-se ao que Santos (2004, p. 88-89) denomina de agricultura de base científica e globalizada, cujas características principais são a simetria direta com os mecanismos da 
produção econômica e suas leis gerais, cujas referências são planetárias, e ser “[...] exigente de ciência, técnica e informação, levando ao aumento exponencial das quantidades produzidas em relação às superfícies plantadas. Por sua natureza global, conduz a uma demanda extrema de comércio.”. Sendo que essa necessidade mercantil transforma o dinheiro em uma informação fundamental.

Ao vincular-se ao capital de forma umbilical, a produção de commodities agrícolas passa a sofrer a interferência direta dos humores do mercado de capitais, pois a formação dos preços é definida por um conjunto de fatores, como a escala da própria produção em si, mas também pela pressão dos mercados compradores, cujas relações com a produção agrícola é a de um investimento de capitais.

Nesse sentido confirma-se a assertiva de Chesnais (1996, p. 308) quando declara que "A mundialização do capital contribuiu consideravelmente para restabelecer a rentabilidade dos investimentos, exercendo forte pressão para o rebaixamento, tanto dos salários, como dos preços de muitas matérias-primas.”.

A questão deixa de ser puramente de produção e de comércio, e passa a ser especulativa, pois o fim maior do processo é a busca pela reprodução do capital. Como as empresas do agronegócio, chamadas de tradings, operam no nível mundial, a competitividade passa a ser o objetivo maior, pois existe uma concorrência extrema. Ao mesmo tempo, há uma formação de oligopólios, que concentra as maiores empresas cuja origem encontra-se nos países da chamada tríade (Estados Unidos, Europa e Japão) como aponta Chesnais (op. cit.).

Ao discutir o agronegócio brasileiro não é possível dissocia-lo de empresas como Archer Daniels Midland (ADM), Bunge, Cargill, Louis Dreyfus, Noble, Basf, Monsanto, Mosaic, Yara, New Holland, Massey Ferguson, Case entre outras que dominam setores estratégicos como a produção de sementes, agrotóxicos, adubos, maquinário, processamento e, também, o financiamento, pois as tradings operam junto aos produtores de forma a tornálos obedientes às suas demandas, visto que os créditos concedidos por essas empresas obrigam uma relação de dependência, tornando cativos os produtores que não dispõem de capital próprio para produzir nos níveis exigidos pelo agronegócio.

O poder de ação das tradings também alcança o setor de transporte rodoviário de cargas que sustenta a maior parte da circulação do agronegócio, pois como aponta Huertas (2014, p. 48) são denominadas de "frotistas" as maiores empresas transportadoras, cujas 
características principais são: possuir mais de uma centena de caminhões e "[...] cujo crescimento foi estimulado pelas tradings ao longo de anos com o financiamento da frota.". Logo, o crescimento em escala dessas transportadoras está em consonância com as demandas ascendentes apresentadas, tendo em vista a matriz rodoviária ainda ser hegemônica no movimento de cargas na região.

Portanto, o conjunto representado pelo agronegócio e o adensamento das relações que sustentam esse conjunto, demandam condições específicas que passam a exigir dos territórios certas características. Como há uma elevação da formação de fluxos, materiais e imateriais, a crescente articulação com as escalas que vão do local ao global terminam por pressionar o Estado, principal agente da reestruturação territorial, a lançar mão de ações voltadas à dotação do território de fixos diversos, bem como de uma regulação específica. Constitui-se, assim, um uso específico do território, o uso corporativo.

Podemos associar essa dinâmica ao estabelecimento do macro-circuito, apontado por Castillo (2004) como o momento em que as grandes empresas acionam os pontos de modernização do território na escala nacional e mundial, na busca por competitividade no mundo globalizado.

O acionamento pode se dar de duas formas, uma remota, por meio dos sistemas informacionais que permitem o controle por parte das corporações das atividades produtivas; e o acionamento direto no território, por meio da produção, originação e processamento, no caso das agroindústrias. Nesse último caso, o sistema de engenharia de transportes é chamado a contribuir com a movimentação de mercadorias, visto que os principais mercados da produção são externos.

Com isso temos a intensificação das demandas pela logística de transportes e de armazenamento, que podemos chamar de logística da produção, que se torna cada vez mais um elemento nodal tendo em vista a intensificação das relações de produção, principalmente dos circuitos espaciais de produção associados aos círculos de cooperação do capital.

Mas, a consolidação do agronegócio em meio ao processo de reestruturação efetivado no território demandou a convergência de interesses das elites nacionais, do Estado brasileiro e das corporações nacionais e internacionais. O processo se efetiva em meio ao período em que uma crise importante é deflagrada no interior do capitalismo, após 1970, exatamente no período em que diversas ações estavam sendo realizadas no interior do território nacional com 
vistas à integração e ocupação. Assim, um quadro nacional é desenhado no curso do processo de ajustes espaciais do capitalismo.

\subsection{UM QUADRO NACIONAL DA REORGANIZAÇÃO DO SISTEMA CAPITALISTA}

É importante frisar que os processos de ajustes espaciais não se dão de forma homogênea e simultânea, ou seja, a transição ocorre de forma diferenciada, pois sua assimilação e disseminação variam de acordo com a realidade social sobre a qual incide. No entanto, se considerarmos o capitalismo enquanto motor movente (SANTOS, 1993) da produção social e como sistema hegemônico, sua evolução termina por afetar o mundo inteiro.

Assim, a estruturação do regime de acumulação capitalista é realizada mediante as interações que se dão em escalas diversas, resultando na correspondência com as transformações "[...] das condições da reprodução do trabalho assalariado.", conforme aponta Lipietz (1988, p. 30). Para o autor, o regime de acumulação é fruto da articulação entre o interior e o exterior de uma formação econômica e social nacional, no bojo da interação entre o capitalismo e outros modos de produção. Sua existência material está vinculada a um modo de regulação, constituído pelos elementos necessários (leis, normas, costumes, mecanismos de regulação) para que haja uma unidade no processo.

A complexidade desse processo explica porque sua disseminação demora a ser efetivada e consolidada, mesmo em áreas em que o capitalismo já possui um estágio avançado. Isso ocorre porque seu avanço pelo mundo implicou em adaptações geradoras de nuances oriundas das sociedades locais onde se instalava.

Para Storper (1991) a crise do sistema capitalista, que se inicia em 1970, e é acentuada na década de 1980, demandou uma reestruturação e uma reorganização espacial, que ainda está em curso, para superar os limites apresentados por este sistema produtivo. Nesse processo, argumenta o autor, ao alcançar a maturidade tecnológica, o setor produtivo passa a criar filiais nas áreas periféricas dos próprios países centrais e depois nos países periféricos. 
Observa-se que na busca por uma manutenção da reprodução do capital, o setor produtivo alarga sua atuação geográfica para além dos países mais ricos e industrializados em um movimento de desconcentração espacial das atividades produtivas, mas mantendo a centralidade no comando das ações produtivas, principalmente no que concerne a concepção e nas estratégias das empresas.

Neste caso, as transformações que ocorrem no interior do modo de produção capitalista, com vistas à superação da crise estabelecida, levam ao estabelecimento de um período de transição, em que temos a ascensão de novos parâmetros internos exigidos ao regime de acumulação capitalista.

Assim, para entendermos os rebatimentos ocorridos no Brasil é necessário analisar as ações e os desdobramentos territoriais, vinculados aos processos mais gerais e sintonizados com os movimentos de reorganização do capitalismo. Observando a singularidade de alguns aspectos, fruto da fricção com a realidade nacional.

Nesse sentido, é importante destacar que a crise mundial estabelecida nos anos de 1970, tem repercussão no Brasil e gera a necessidade de alterações na consecução de projetos, tendo em vista a crise fiscal do Estado e sua incapacidade de gerir e fomentar as propostas implantadas ou em fase de implantação.

Essa crise aprofunda-se na década de 1980, e seus desdobramentos apresentam-se em todas as esferas do país e, segundo Becker e Egler (1993, p. 227):

Os efeitos da crise dos anos 80 atingem diretamente o aparelho do Estado centralizador que levara ao extremo o processo de construção do Estado à frente da construção da nação. O regime autoritário militar impôs sua imagem de nação à sociedade, eliminando os mecanismos de representação e participação que permitiriam uma solução negociada para a superação da crise. Por sua vez, a cristalização das estruturas políticas constitui um entrave às novas formas de gestão descentralizadas e flexíveis, exigidas pela reestruturação do sistema capitalista mundial.

Na dinâmica interna brasileira, o Estado centralizador passa a tomar medidas para a manutenção da produção cujo modelo era corroído pela crise internacional. Um dos mecanismos acionados pelo governo foi o arrocho no mercado de trabalho quanto à questão salarial como aponta Ferreira (1993). 
Para tentar minimizar os efeitos dessas estratégias, foi necessário adotar ações face à crise estabelecida, no sentido de aliviar as pressões sociais surgidas em decorrência das dificuldades enfrentadas pela maior parte da população. Nesse sentido os diversos planos e projetos vão se conformando de acordo com as estratégias previamente pensadas pelo poder público, porém com atualizações para resolver as questões urgentes que se delineiam.

Como exemplo, o II PND que fora pensado para o período de 1975 a 1979, enfrenta as condições adversas da crise existente, como confirma Calaça e Inocêncio (2010, p. 286) ao apontarem que "O II PND foi elaborado em virtude das profundas alterações ocorridas no cenário mundial, tendo como referência a crise do petróleo e a estrutura produtiva nacional, com o esgotamento do "milagre".".

Esse plano tem importância estratégica para nossa análise, pois favoreceu as áreas de Cerrado que passaram a ser consideradas fundamentais para a produção de alimentos, bem como importante para a integração nacional por contemplar um objetivo notório dos governos militares no conjunto de estratégias para a Amazônia.

Estendendo o quadro crítico para a América Latina na década de 1980, Becker e Egler (1993, p. 236-237) argumentam que "Na verdade, a crise da América Latina é a crise do capitalismo tardio, que assume expressão máxima no Brasil.”. Os autores explicam que o Estado buscava como estratégia avançar sobre a economia para além do caráter de empresário, agindo ainda como agente financiador.

Mas diante do novo cenário da economia-mundo, a crise fiscal que assolava o Estado, refletida nas dívidas interna e externa, não permitiu que ele mantivesse o ritmo de investimentos, principalmente para a indústria de bens de capital e de bens intermediários. Para reforçar a ideia de como a crise que se acentuava na década de 1980, teve reflexos diretos nas ações governamentais, Calaça e Inocêncio (2010, p. 287) apontam que:

O III PND, previsto para ser implantado em fins de 1979, não se desenvolveu, pois o Brasil passou a enfrentar sérias dificuldades de financiamento, comprometendo a sua capacidade de colocar em prática os programas de desenvolvimento econômico. A década de 1980 é considerada, por muitos autores, como a "década perdida", em virtude do baixo desempenho econômico. 
Como o Estado não tinha mais condições de financiar a produção diretamente, a abertura permitiria a entrada de divisas via investimentos diretos, principalmente no incremento do parque fabril brasileiro. E, como o Brasil já possuía um mercado interno, notadamente de uma classe média que tinha condições de consumir, a produção tinha a lógica do mercado nacional e a possibilidade de exportação, apesar da crise de mercado nos países centrais que seriam os potenciais importadores.

Os setores industriais já estabelecidos eram fundamentais para a manutenção do crescimento econômico do país e neste caso a redução dos investimentos públicos poderia desestabilizar o sistema produtivo como um todo, o que passou a exigir um novo modelo. A desaceleração da indústria nacional implicaria em um grande ônus, pois este setor já se configurava como um grande empregador, desencadeando problemas nas cidades operárias e nas grandes metrópoles.

O Estado necessitava de divisas para fazer frente ao serviço da dívida e as ações que se seguiram nos planos buscava priorizar setores que pudessem favorecer as contas correntes do país, implicando em mudanças estruturais que permitissem uma recuperação econômica no contexto da crise.

Assim, a modernização da agricultura, elemento dinamizador dos processos que se intensificariam no interior do Brasil, continuava como elemento nodal das políticas públicas, assumindo caráter de urgência na sua difusão, onde as áreas de Cerrado são definitivamente incorporadas ao novo processo produtivo.

A modernização da agricultura aqui tratada reflete o resultado de acontecimentos mais amplos e que envolve transformações em períodos históricos diferentes. Mas, os acontecimentos do pós-guerra, que representa a fase mais acentuada dos processos de mudança da base técnica e relações de trabalho, como nos informa Suzuki (2007) nos interessam diretamente porque representam:

[...] a fase última, com forte presença da indústria na agricultura, constituindo os complexos agroindustriais, cujos vínculos são para além de algumas linhas de relações, já que sua estrutura se estabelece em rede, em que cada cidade é ponto nodal para a realização da atividade de produção, bem como da circulação dos seus produtos, particularmente no que concerne às commodities agrícolas. (SUZUKI, op. cit., p. 93). 
Mas a integração junto ao novo cenário econômico cobra um alto custo social, na medida em que se coaduna com um modelo produtivo no campo que é excludente e concentrador.

As ações públicas apresentaram resultados contraditórios na medida em que buscava uma maior integração com os mercados internacionais, mas a condição fiscal do Estado impedia a implantação da infraestrutura básica necessária para um crescimento econômico, cujas condições de arrocho incidiam sobre a parcela mais carente da população.

A pressão popular em meio ao cenário de crise exigia investimentos, porém o pagamento da dívida externa era a prioridade e corroía as divisas nacionais. Nesse contexto, o peso das exportações aumentava na medida em que sustentava o serviço da dívida, mesmo não conseguindo reduzi-la em virtude das taxas de juros praticadas.

Em meio a estas condições adversas, foram engessados os investimentos na infraestrutura, redução na concessão de créditos - como no caso do Sistema Nacional de Crédito Agrícola, que era fundamental para a intensificação do modelo agroexportador - e uma luta constante contra a inflação. Somada à crise econômica da década de 1980 veio a crise política, cujo modelo se esgotava frente à pressão por abertura política e redemocratização.

Os planos de integração do território brasileiro - principalmente aqueles iniciados com a Marcha para o Oeste, seguido posteriormente pelo Plano de Metas e aprofundado pelos governos militares -, encontra seu limite em virtude da conjuntura internacional. Nesse processo de reestruturação, as economias periféricas, como a brasileira, enfrenta a crise com um modelo de base keynesiana, ou seja, de intervenção direta e determinante do Estado na economia e na gestão do território.

Como já fora colocado, o Estado brasileiro agiu como financiador e empresário, demonstrando seu caráter centralizador, buscando dispor o território para atender as demandas do mercado nacional e internacional. Esse viés corporativista em relação ao território resultou num processo de incompletude, em decorrência dos limites já apontados, criando um quadro de irracionalidade de acordo com a lógica capitalista.

O resultado dessa incompletude emerge com intensidade pelas deficiências apresentadas em diversas áreas, como no caso da engenharia de transportes que não 
acompanha as demandas e impõe limitações de fluidez, aumentando o que se convencionou chamar de custo Brasil.

Mesmo com as tentativas de desconcentração espacial, as melhores condições de fluidez mantiveram-se no eixo Sudeste-Sul, enquanto para o interior do país a realidade era de um sistema incompleto, principalmente para as áreas mais distantes deste eixo.

Para Mato Grosso, a fluidez continuava a depender das poucas rodovias federais existentes, cujos investimentos em ampliação e manutenção cessaram em meio às condições de adversidades do período de crise, e das rodovias estaduais precárias que formavam a sua malha rodoviária.

Partindo do sistema de transportes como um todo, observa-se atualmente que a integração do modal rodoviário com outros modais também apresenta limites, pois o modal ferroviário só é conectado com a malha rodoviária no final da década de 2000, restringindo-se ao sul de Mato Grosso.

Essa realidade passa a exigir da classe produtora a criação de estratégias individuais para a manutenção da competitividade diante do mercado internacional.

Em suma temos ações centralizadoras do Estado na busca por uma integração e uma desconcentração, mas as condições favoráveis das regiões Sudeste e Sul continuavam atraindo os maiores investimentos. A criação das infraestruturas no interior do país favoreceria um movimento de desconcentração, pois o sistema produtivo de base modernizada exigia insumos de setores diversos.

No entanto, a realidade que se apresentava era da continuidade da concentração no mesmo eixo dinâmico, mas alguns setores da agroindústria começaram a se instalar no Centro-Oeste, atraídos por incentivos fiscais (inicialmente oferecidos pelo governo federal e posteriormente disponibilizados nas esferas estadual e municipal) e ainda pela proximidade da produção (soja, algodão, milho, carnes) que se consolidava e mantinha um ritmo de crescimento elevado.

Esse novo cenário é fruto das ações políticas que criam os objetos ou que incidem sobre os já existentes, refuncionalizando-os, provocando uma reestruturação do território mato-grossense a partir dos diversos planos e programas, notadamente do governo federal, cujos rebatimentos oportunizaram às grandes corporações capitalistas as condições 
primordiais para a sua consolidação no conjunto do agronegócio. As políticas territoriais implantadas, sob a égide dos processos de integração e ocupação do território nacional, serão mais detalhadas no capítulo a seguir. 


\section{O ESTADO BRASILEIRO E A REESTRUTURAÇÃO DO TERRITÓRIO}

Os ajustes espaciais demandados pelo processo produtivo exigem do território sua reestruturação para possibilitar a operacionalização da produção e a reprodução do capital. Como os custos para a efetivação dos investimentos são elevados, inibem a iniciativa privada, pois não interessa ao capitalista imobilizar recursos cujo retorno na forma de lucro se mostre imprevisível ou demorado.

Damiani (2004, p. 42) ao argumentar sobre a lentidão de rotação de capitais fixos pontua, “A criação de infra-estruturas físicas é problemática já que envolve uma porção de capital fixo de lenta realização da valorização implicada, com dificuldades nas formas de amortização do capital investido", como é o caso dos sistemas de engenharias voltados para os fluxos materiais e imateriais, caso dos transportes, energia e comunicações que eram necessidades urgentes para a efetivação de uma integração completa. Nesse sentido, Carlos (1994, p. 130) ao discutir a questão do capital e a sua necessidade premente de movimento pois a realização do seu processo de valorização se dá com a repetição ininterrupta do ciclo do próprio capital -, informa que os investimentos em setores estratégicos favorecem a aceleração desse processo e assim, “[...] o desenvolvimento dos transportes e da rede de comunicação, diminuindo o tempo gasto no processo de circulação, aumentando a frequência dos deslocamentos, tenderá a diminuir o tempo de cada rotação do ciclo do capital". Assim, segundo a autora, é na articulação entre a produção e a circulação, que formam uma unidade, que temos a materialização do capital e a sua consequente produção do espaço.

A produção do espaço decorrente desse processo se metamorfoseia na medida em que os processos de articulação entre produção e circulação são aprofundados, mas a demanda inicial para o processo de produção e reprodução do capital prescinde das condições ideais de realização. Para resolver o problema, o Estado passa a investir em setores nodais, criando as infraestruturas essenciais para a viabilidade do processo produtivo, principalmente nos níveis exigidos a partir da integração aos mercados internacionais. Posteriormente o agente privado se associa ao projeto integrador com a produção em si, nesse caso já em condições mais favoráveis. 
Nesse contexto, fica evidenciada a argumentação de Becker (2007, p. 294) sobre o papel relevante do Estado em relação ao planejamento do território, mesmo com o avanço inconteste do poder do setor corporativo em tempos de globalização, quando a autora coloca que:

É o Estado que realiza investimentos vultosos e de longa maturação, tais como grandes projetos estruturantes, que a sociedade não pode pagar de forma direta e o setor privado não tem interesse em assumir. Realiza também investimentos de interesse social, ambiental e regional, igualmente desinteressantes ao setor privado.

Temos claro que as ações do Estado não estão vinculadas apenas aos interesses dos grupos privados, pois as políticas territoriais implicam em estratégias do poder público em controlar o próprio território e, no caso brasileiro, a proposta de ocupação e integração era bem clara e premente. Porém, entendemos que existe uma associação entre estes dois agentes, Estado e o Mercado, cujos resultados implicam em mudanças importantes na produção do espaço.

Para Mészáros (2011, p. 122), o Estado, de forma totalizadora, apresenta a mesma divisão do trabalho de base hierárquica e estrutural presente nas unidades de reprodução econômica. Logo, ele se torna imprescindível para o capitalismo, pois procura manter o controle - mesmo que não o faça completamente - das oposições surgidas " [...] da dualidade disruptiva dos processos socioeconômicos e políticos de tomada de decisão sem os quais o sistema do capital não poderia funcionar adequadamente.”.

Assim, o Estado é chamado a intervir nas estruturas para que a dinâmica de reprodução ampliada do capital possa efetivar-se. Por isso é importante salientar essa condição de organizador do processo produtivo, de indutor das condições de reprodução e da difusão dos preceitos de produção e consumo. Dessa forma, para as áreas até então pouco integradas à lógica capitalista, o estreitamento de relações com a nova realidade mediada pelo capital é desestabilizador das condições anteriormente estabelecidas. O ideário de "áreas vazias" denotava a necessidade de um novo paradigma. A integração era tanto territorial quanto de mercado. 
Nesse contexto, trataremos das ações efetivadas pelo Estado brasileiro, principalmente a partir da década de 1970, que resultaram em transformações profundas no Brasil. Este trabalho destaca essas transformações no Brasil Central, que se relacionam com o estado de Mato Grosso em sua dinâmica de reestruturação territorial.

\subsection{A DINÂMICA DOS PROCESSOS DE INTEGRAÇÃO E OCUPAÇÃO}

Considerando as dimensões continentais do Brasil e a necessidade de uma ocupação efetiva e de uma integração que se fazia urgente - visto o processo de concentração estabelecida na costa do país notadamente no Centro-Sul -, o Estado brasileiro adotava ações com vistas ao controle maior do seu território.

Esse controle era necessário, entre outros motivos, pela abundância de recursos existentes e pelas demandas surgidas da maior integração do país com a economia-mundo. Mas, é importante lembrar que a ocupação pretendida estava direcionada a uma área já ocupada por nações indígenas e comunidades tradicionais como atesta Martins (1997, p. 8586). No entanto esses ocupantes não estavam inseridos na lógica estabelecida.

Assim, a maior integração com a lógica capitalista exigia cada vez mais mudanças na gestão do território, implicando na criação de dispositivos que permitissem um crescimento econômico sustentado com vistas à manutenção do regime político, principalmente no caso do período de regime autoritário pelo qual passou o país.

Para Taylor e Flint (2002, p. 206) o Estado enquanto instituição garante a manutenção de duas situações fundamentais: disponibilizar as condições de acumulação de capital e manter a legitimação do sistema, sendo esta legitimação entendida como um equilíbrio variável entre as forças de consenso e coação. Quando há uma estabilidade, o consenso é suficiente para manter as condições de governabilidade.

Quanto às condições propícias para a acumulação de capital, entendemos que o Estado se adapta às transformações capitalistas e é elemento fundamental do funcionamento do próprio capitalismo, pois a riqueza produzida não é virtual, ela é real e se territorializa em forma de bens e propriedades. Esses por sua vez são regidos por leis criadas e reguladas pelo Estado. 
Nesse contexto, cabe ao Estado coordenar as ações dirigidas ao território, pois ele deve atender aos interesses de um coletivo maior. No entanto, prioriza-se o atendimento dos interesses coletivos dos agentes hegemônicos vinculados ao mercado, pois como esses agentes comandam os setores produtivos dentro da divisão territorial do trabalho, sua posição no jogo das forças políticas é potencializada no âmbito da racionalidade capitalista.

Como os interesses são diversos e contraditórios há, de acordo com Becker (2006, p. 398), uma coordenação por parte do Estado da nova divisão inter-regional do trabalho, cabendo-lhe a reorganização do caos das relações sociais a partir da imposição da sua racionalidade enquanto agente. Para tal, utiliza o espaço enquanto instrumento privilegiado. Como o econômico se reconsidera espacialmente, por meio dos fluxos e dos estoques, cabe ao Estado impor certo controle e coordenação, rompendo com o espaço anterior e produzindo o seu próprio espaço, impondo uma ordem “[...] espacial, vinculada a uma prática e concepção de espaço logística, global, de interesses gerais, estratégicos, que é contraditória à prática e concepção de espaço local, dos interesses privados e objetivos particulares.”.

Essas considerações enfatizam que os interesses estratégicos defendidos pelo Estado, por mais que busquem uma lógica totalizadora, podem sofrer influência dos interesses de grupos privados no âmago das relações sociais, principalmente quando os agentes hegemônicos pactuam ações integradas. Logo, o que é estratégico para o Estado pode ser consubstanciado aos interesses de coletivos privados, nacionais e/ou internacionais, cujos interesses são alinhados.

A questão torna-se mais complexa à medida que a integração é acentuada, pois se trata nesse caso de conciliar estratégias diversas com rebatimentos cada vez mais profundos no território, tendo em vista o nível e a qualidade das relações estabelecidas, incidindo sobre o setor produtivo que se torna obediente a comandos externos, dentro da lógica contida na divisão territorial do trabalho.

Com o estreitamento do vínculo do território usado pelos grupos hegemônicos com os processos políticos do Estado brasileiro, houve uma maior articulação entre as diversas regiões brasileiras chamadas a integrar as novas relações mediadas pelo Estado e consoantes com as demandas dos grupos corporativos nacionais e internacionais que se associaram ao projeto nacional. 
Fica evidente o protagonismo do Estado nas ações executadas dentro das políticas territoriais, pois coube a ele criar, por meio de planos e programas, uns mais específicos, outros mais gerais, as bases para uma nova configuração do território.

Calaça e Inocêncio (2010, p. 272-273) ilustram bem essa condição quando informam que "A análise da vinculação entre Estado e território no Brasil parte do princípio de que o Estado foi, ao longo de diversos períodos da história desse País, o mais importante ator das políticas territoriais.".

O protagonismo do Estado consolida-se nos períodos em que as condições mais amplas, de ordem global, se encontram em transição, como nos períodos das crises predecessoras da emergência de novos paradigmas no setor produtivo. A grande crise da década de 1930 e os desdobramentos da Segunda Guerra Mundial exigiram dos Estados intervenções fundamentais para o funcionamento do sistema, nesse caso do capitalismo.

Nesse ínterim, a nova realidade baseada na ordem global hegemônica intensifica no território as mudanças já em curso, principalmente no setor econômico, em que o Brasil buscava uma ampliação e consolidação do seu parque fabril dentro de um processo chamado de substituição de importações.

O viés economicista do Estado e a sua importância como agente estruturador do território fica evidente na afirmação de Costa (2000, p. 51) sobre o segundo governo de Vargas na primeira metade da década de 1950:

Para alcançar os objetivos de um desenvolvimento industrial acelerado e o mais auto-sustentado possível (essa era a tônica da política do governo Vargas), o Estado priorizou suas políticas públicas e seus investimentos em programas maciços de infra-estrutura, energia e transportes.

$\mathrm{O}$ autor destaca como essas ações permitiram ao governo de Juscelino Kubitschek implantar o seu Plano de Metas (1957-1960) que alteraria profundamente a organização produtiva do país bem como a sua estrutura territorial como um todo.

A região Centro-Oeste foi um dos alvos das políticas de ocupação e integração, por apresentar um quadro de inclusão no conjunto do mercado interno nos anos de 1950, bastante restrito, já que se desenvolviam apenas as áreas próximas da região mais dinâmica, 
configurando-as inclusive como uma "[...] extensão da agricultura do Sudeste nas áreas que lhe são contíguas.” como argumentam Goldenstein e Seabra (1982, p. 32).

No período compreendido pelos governos do regime militar temos uma complexidade histórica em virtude de um contexto de crises (década de 1960), milagres (1968 a 1972) e a recessão dos anos de 1980, conforme apontam Becker e Egler (1993, p. 136) que enfatizam como o Estado manteve elevados níveis de investimentos e uma intervenção efetiva no aparato produtivo, ao custo do endividamento, com uma proposta de modernização baseada também “[...] num projeto territorial fundado no ideário da integração nacional e do Brasil potência.”.

Algumas ações tiveram impactos mais profundos na reestruturação territorial brasileira com vistas ao propósito de integração que se almejava. As razões para o sucesso ou fracasso de algumas iniciativas estão relacionadas a uma série de fatores, com ênfase para os desdobramentos das crises internacionais surgidas a partir da década de 1970, e pelas condições internas do sistema produtivo.

Este período, em virtude da condição política estabelecida, implicou em uma massiva campanha nacionalista por parte do governo para solucionar problemas regionais com a disponibilidade de recursos e terras, principalmente da Amazônia e das áreas da fronteira agrícola do Centro-Oeste.

O acesso, até então dificultado pela inexistência de infraestruturas, como a de transportes e energia, demandava investimentos, como ocorreu com a implantação de rodovias de penetração. Torres (2005, p. 274) ilustra bem esse contexto:

A década de 1970, notadamente a sua primeira metade, foi marcada por uma onda de doentio ufanismo. O "país que vai pra frente" integrava e "levava civilização e progresso" à Amazônia a partir de megalômanos projetos de rodovias.

A rodovia Cuiabá-Santarém (BR-163) fazia parte deste projeto nacional de integração dos denominados espaços vazios. Espaços esses assim adjetivados em virtude de serem vazios da nova dinâmica consoante com um processo de racionalidade em curso, cujo discurso e ideologia pregavam um caráter progressista no cerne de uma modernização conservadora. 
Após essa breve introdução da condição do Estado enquanto agente estruturador do território, detalharemos as ações programadas e efetivadas no conjunto das políticas territoriais. Para tal partiremos da análise dos planos e programas que mais impactaram as áreas de Cerrado do Brasil Central.

Dividiremos a discussão em duas etapas, a primeira compreendendo a construção de Brasília, as ações do Plano de Integração Nacional (PIN), o I e o II Plano Nacional de Desenvolvimento (PND) juntamente com os seus programas e ações mais representativas para a reestruturação territorial da região Centro-Oeste que redundou na criação e consolidação do agronegócio na região.

A segunda etapa enfatizará os desdobramentos resultantes das ações voltadas ao setor de transportes, pois como a proposta de integração possui estreito vínculo com a necessidade de fluidez, discutiremos as propostas e ações dos Eixos Nacionais de Integração e Desenvolvimento (ENIDs) e os desdobramentos do Plano Nacional de Logística de Transportes (PNLT), que foram direcionadas para Mato Grosso.

\subsection{AS POLÍticas TERRITORIAIS COM IMPACTOS NO CENTRO-OESTE BRASILEIRO}

\subsubsection{A construção de Brasília}

Construída durante o governo de Juscelino Kubitschek (1956-1960), Brasília representou muito mais que a nova capital do Brasil, pois se tornou o símbolo de uma nova etapa, de um novo surto de crescimento, principalmente o industrial, fortalecendo o discurso do governo JK de cinquenta anos em cinco, dentro do Plano de Metas.

A nova realidade firmada neste período é fruto de um conjunto de fatores internos e externos, pois o período do pós-guerra foi marcado pela reorganização da produção, pela reconstrução de países e pela difusão das tecnologias criadas para atender o esforço de guerra. No caso brasileiro esse esforço revelou a precariedade de regiões quanto ao acesso, pois o isolamento absoluto ou relativo de algumas áreas ficou mais evidente, como apontam Santos e 
Silveira (2004, p. 252-253) ao discutirem a questão, complementando-a com a seguinte constatação:

[...] a construção de Brasília com suas interligações com o resto do território, juntamente com o Plano de Metas e as legislações destinadas a suprimir entraves ao intercâmbio entre Estados, tiveram um papel importante na criação de uma certa unidade nacional, devida à superposição entre unificação do território e unificação do mercado.

Assim, interesses territoriais se fundem aos interesses de cunho econômico na tentativa de consolidar uma transição já em curso que demandava um esforço da nação em vários aspectos, como a tentativa de industrializar-se.

O Plano de Metas do governo JK é considerado como um grande avanço para a consolidação do setor industrial do Brasil, inclusive com a abertura para multinacionais que passaram a compor este setor antes restrito a um conjunto bastante incompleto para as necessidades do país.

Mesmo baseado no espírito de nação e na ideia de integração, fica evidente, como afirma Fausto (2000, p. 236) a existência de uma transição ideológica, destacada na seguinte argumentação:

O governo JK promoveu uma ampla atividade do Estado tanto no setor de infra-estrutura como no incentivo direto à industrialização. Mas assumiu também abertamente a necessidade de atrair capitais estrangeiros, concedendo-lhes inclusive grandes facilidades. Desse modo a ideologia nacionalista perdia terreno para o desenvolvimentismo.

Além do setor industrial foco de grande atenção, principalmente para a produção de bens de capital que permitiriam uma reestruturação mais completa do setor, os investimentos em infraestrutura de transportes também foram priorizados. Dentro das trinta metas estabelecidas, o setor de transportes foi considerado fundamental para o processo de integração territorial (VESENTINI, 1986).

Mas, somada à dinâmica de integração econômica em curso, aflorava também as desigualdades regionais, exigindo ações voltadas à redução das assimetrias entre as regiões. 
Tendo a região Sudeste como parâmetro, muito havia a ser feito para reduzir os desequilíbrios existentes. Como a realidade dessa região era fruto de um longo processo de construção histórica, cabia ao Estado reduzir o abismo que separava os vários brasis.

Como houve uma intensificação da centralização por parte do governo federal, em detrimento de uma menor participação das instâncias estaduais e municipais (VESENTINI, op. cit.) gerando um Estado planificador, as estratégias de integração e ocupação respondiam a um imperativo maior, ou seja, atender aos interesses da nova organização produtiva em consonância com o capitalismo na sua fase industrial monopolista (COSTA, 2000).

A proposta de integração não respondia naquele momento apenas ao seu caráter territorial, mas sim engendrava estratégias políticas que se voltavam para sincronizar o país com a nova conjuntura internacional do capitalismo, pois segundo Smith (1988, p. 202):

O capitalismo define a escala geográfica global precisamente à sua própria imagem. Apesar das forças e dos processos econômicos que ajudam a constituí-lo, a definição da escala global é quinta-essencialmente política; é o produto das relações de classe do capitalismo.

Como efeitos territoriais dessa dinâmica, tivemos escolhas internas que cobrariam seu preço nos períodos subsequentes, como a ênfase dada ao sistema de transportes de base rodoviária, cuja malha irrigaria o território brasileiro a partir da nova capital implantada no Planalto Central.

Vesentini (1986, p. 104) indica as seguintes rodovias criadas dentro do Plano de Metas: "Belém-Brasília (2 000 km), Belo Horizonte-Brasília, (700km), Goiânia-Brasília (200 km), Fortaleza-Brasília (1 $500 \mathrm{~km}$ ) e Acre-Brasília (2 $500 \mathrm{~km}$ )”. Fica evidente a magnitude e a importância da criação desses eixos os quais facilitavam a circulação de pessoas e mercadorias, criando um processo de interação que fortalecia as relações entre as diversas áreas com suas especificidades.

Era a aurora de um Brasil cujas bases produtivas migravam de um padrão competitivo para um padrão monopolista como alerta Vesentini (op. cit., p. 105) a partir dos estudos de Francisco de Oliveira (1976). O grande empreendimento era priorizado, como no caso da indústria automobilística de capital estrangeiro implantada no $\mathrm{ABC}$ paulista, que chegou a 
concentrar cerca de $78 \%$ da produção de automóveis do país de um total de 133 mil unidades (FAUSTO, 2000, p. 236).

Moreira (2012, p. 255) entende que o período de 1950 a 1970, apresentou em seu conjunto uma fase da concentração, polarização e diferenciação do Sudeste. Para o autor, ocorre uma maior diversificação da produção industrial associada à concentração dessa produção no Sudeste em detrimento das demais regiões. Para ele o quadro que se estabeleceu foi:

Portanto ao tempo que nacional e regionalmente o Nordeste e o Sul se tornam menos industriais e mais agrários, o Sudeste se torna mais industrial e menos agrário, e o Centro-Oeste e o Norte incorporam-se a esta divisão inter-regional do trabalho como típicas fronteiras de expansão agropastoril do Sul e de São Paulo.

A questão da integração de mercados inter-regionais exigiu uma reestruturação da produção, com uma dinâmica de industrialização e da produção agropecuária reestabelecidas sobre novas bases. Como a intensificação e diversificação da industrialização converge para o Sudeste, principalmente para São Paulo, cria-se uma nova funcionalização das demais regiões, que passam a depender do centro hegemônico em relação aos bens manufaturados de setores diversos.

Da mesma forma, a necessidade de matérias-primas por parte do Sudeste é ampliada, determinando para as regiões Norte e Centro-Oeste a condição de fronteira agropecuária, cujas bases de uma modernização conservadora estavam sendo sedimentadas.

A intensificação das relações entre as regiões brasileiras nesse novo cenário exigiu a expansão e consolidação do sistema de transportes, caracterizando esse setor como estratégico e fundamental aos interesses estabelecidos.

Mas, como no Plano de Metas a ênfase ao modal rodoviário foi consolidada, com o império dos veículos automotores, os demais setores de transportes fundamentais como as ferrovias e hidrovias não acompanharam o boom de investimentos e foram sucessivamente relegados a um papel secundário. Nesse ponto a criação e a manutenção da malha rodoviária tornavam-se cada vez mais prioritárias. 
O país, ao contrário das nações centrais que buscaram a intermodalidade no setor de transportes, prioriza um único modal e se torna refém das suas escolhas, cujas diretrizes têm continuidade nos períodos seguintes.

\subsubsection{Os Planos Nacionais de Desenvolvimento e os impactos territoriais}

Em consonância com o projeto de internacionalização que se propunha para o Brasil, exigente de uma modernização do território já em curso, observou-se na segunda metade da década de 1960, o surgimento de grandes planos nacionais para alcançar esses objetivos. Esses planos apresentavam duas características importantes: perspectiva geopolítica explícita em relação à questão territorial, partindo de um discurso ufanista na tentativa de legitimar o regime autoritário instalado; e viés economicista, pois buscava o crescimento econômico a todo custo.

A expansão e consolidação do processo de industrialização almejada pelo Estado brasileiro apresentavam limites quando o processo de concentração do parque industrial brasileiro chegava ao seu extremo já na virada para a década de 1970.

Segundo Moreira (2012, p. 256) a insustentabilidade da diferenciação-concentração industrial gera efeitos como a deseconomia de escala a qual afeta negativamente a produtividade e aumenta os custos operacionais, impedindo um crescimento mais estável da economia e reduzindo a continuidade do desenvolvimento brasileiro.

Em virtude dessa conjuntura, os governos militares que ascendem ao poder a partir de 1964, criam planos voltados para sanar as incorreções do processo de industrialização e da adequação territorial já em desenvolvimento.

Becker e Egler (1993, p. 144) indicam a intenção de adequação da estrutura territorial a um projeto de industrialização, quando no I PND (1972-1974) e no II PND (1975-1979) houve a consolidação dessa ordenação territorial com o projeto geopolítico; enquanto Moreira (2012, p. 256) assinala que os governos militares buscavam estratégias de redistribuição da indústria para reduzir a concentração existente, sendo o I PND voltado para a modernização da agricultura, o II PND voltado para a distribuição da indústria e o III PND (1980-1985) para corrigir os rumos. 
Ao buscar firmar-se no cenário internacional, observa-se a tentativa de consolidação da condição industrial como elemento fundamental para o projeto territorial brasileiro. Nesse sentido, Araújo (1993, p. 87) destaca que entre os anos de 1960 e 1980, o Brasil “[...] tinha como projeto básico construir um parque industrial importante e com isso entrar para o restrito elenco das principais potências mundiais.", indicando que os desdobramentos desse projeto industrializante repercutiram em todas as regiões brasileiras, cada uma contribuindo com etapas específicas do processo produtivo, com vistas a atender os planejamentos regionais pensados para o país.

Evidencia-se uma funcionalização do território, havendo uma divisão inter-regional do trabalho na medida em que cada área participa com suas potencialidades no conjunto da economia e sob os auspícios dos projetos implantados e pensados de forma centralizada.

Para a região Centro-Oeste cabe destacar o argumento de Duarte (1988b, p. 251), quando esse considera dois tipos para a região: áreas com estruturação capitalista consolidada e áreas que são fronteiras do capital. No âmbito das suas singularidades esses tipos respondem pela divisão social do trabalho na região, mas no seu conjunto, são articuladas com a totalidade espacial e referidas ao desenvolvimento capitalista nacional em sua dimensão espacial.

É importante assinalar que não existem áreas nesse contexto soltas ou independentes, mas sim níveis diferenciados de integração. Para aquelas menos integradas, passa a haver uma maior exigência rumo ao estreitamento das relações sob a égide da urbanização que se aprofunda.

O novo perfil da sociedade brasileira, nesse ponto já de base urbana, demandava aumento no consumo em dois níveis: consumo relativo, pela qualidade das exigências e consumo absoluto, pelo aumento populacional. Assim, o país necessitava se estruturar para atender a demanda sem depender em demasia da importação dos bens necessários à reprodução da vida urbana que se intensificava. Esse cenário apresenta a condição em que a urbanização permanente sustentaria o crescimento industrial, como apontam Becker e Egler (1993 p. 146) ao assinalar que a “[...] urbanização do território tornou-se, então, uma estratégia para o desenvolvimento do país.”.

Além das demandas urbanas, principalmente das grandes cidades, havia uma emergência de integração que foi consolidada com os planos nacionais que vislumbravam 
impulsionar as fronteiras econômicas. Costa (2000, p. 63-64) ao discutir as políticas territoriais efetivadas no percurso dos governos militares apresenta o seguinte quadro:

O principal plano global de desenvolvimento desse período, já na década de 70, é o I PND - I Plano Nacional de Desenvolvimento Econômico e Social, válido para os anos de 1972 a 1974. [...] De modo geral, o I PND acentua a tendência do Estado de procurar enfocar suas políticas territoriais através de estratégias de "integração nacional", ou seja, procurar expandir a "fronteira econômica" do país, a partir do Centro-Sul, na direção do Centro-Oeste, Amazônia e Nordeste.

$\mathrm{O}$ autor frisa que o entendimento de fronteira econômica é estendido às instâncias agrícola, agroindustrial, industrial, urbana, de povoamento e de infraestrutura regional.

Já Calaça e Inocêncio (2010, p. 284) apontam para a execução de obras de infraestruturas, como a de transportes, corredores de exportação e telecomunicações ocorridas durante a vigência do I PND, caracterizando este plano como sendo uma continuidade das ações do Plano de Metas, pois consolidava a reestruturação territorial voltada para a expansão capitalista em curso.

Como as regiões Centro-Oeste e Norte não estavam plenamente integradas ao restante do território, inclusive em relação à nova dinâmica da economia capitalista, configuravam-se como áreas de fronteira a serem incorporadas e, devido ao perfil produtivo e de potencialidades, caracterizavam-se como fronteira agrícola.

Segundo Silva (2007, p. 291) “A fronteira agrícola capitalista se refere a um processo de integração de um espaço geográfico à economia nacional e global, por meio da expansão territorial da agricultura.".

$\mathrm{O}$ autor informa ainda que o avanço da fronteira, no bojo das transformações pelas quais passou o campo brasileiro a partir da década de 1970, provocou uma maior interação espacial com espaços urbano-industriais em diversas escalas.

Já Becker e Egler (1993, p. 202) tratando da fronteira em um conjunto mais amplo, entendem-na como sendo a constituição de um espaço econômico, social e político não totalmente estruturado, sendo potencialmente um gerador de realidades novas. Consideram que a geopolítica do Estado brasileiro foi responsável pela construção não apenas de uma 
fronteira, mas de "[...] muitas fronteiras, que deveriam oferecer perspectivas de crescimento econômico, de solução de tensões sociais e do pleno exercício do poder sobre o tempo e o espaço.”.

A dinâmica da criação de fronteiras decorreu dos pressupostos dos processos de urbanização e industrialização do Brasil e dos desdobramentos da Revolução Verde. Esses processos se deram no contexto da crise energética mundial e das ações do Estado com vistas a constituir os corredores de exportação dos produtos agrícolas e os complexos agroindustriais por meio dos polos de desenvolvimento (SILVA, 2007, p. 293).

Como já salientamos, enquanto os países centrais apresentavam uma crise de mercado, alguns países periféricos como o Brasil apresentavam um crescimento desse setor, logo havia a possibilidade de novas oportunidades para as empresas estrangeiras que buscavam manter elevados padrões de competitividade no novo ambiente de acumulação e regulação.

Para o setor produtivo de insumos e maquinários agrícolas dos países industrializados, o campo brasileiro apresentava um cenário promissor, tendo em vista a grandiosidade das áreas disponíveis, que eram potencialmente adaptáveis aos novos padrões de produção de alimentos existentes que já estavam disseminados pelos países mais desenvolvidos. Inclusive o abrupto aumento do valor das commodities, tanto as minerais quanto as agrícolas, criou um verdadeiro "boom" dessas mercadorias a partir de 1972, como atesta Hone (1973, p. 83) e Campos (2012, p. 5) o que favorece e legitima ideologicamente as políticas públicas voltadas para esses setores produtivos. No Brasil é sintomática a evolução da produção de commodities que se tornam fundamentais para as finanças internas frente ao mercado externo.

Porém, para que o circuito produtivo fosse completado havia a necessidade de uma nova formatação do processo produtivo, via modernização da base de produção, ação que foi prontamente liderada pelo Estado brasileiro.

Uma das metas almejadas era o crescimento da produção do setor primário que exigiria um grande esforço dos setores público e privado segundo consta no programa de ação do governo para a região Centro-Oeste, dentro do II PND:

As expectativas quanto à sua viabilização repousam nas possibilidades de incorporação de imensas áreas territoriais ainda não ocupadas (Território Federal de Rondônia, norte do Mato Grosso e de Goiás), [...]. A introdução de melhores insumos e de inovações tecnológicas nessas áreas permite a 
obtenção de ganhos líquidos de produtividade diferentes dos atuais." (BRASIL, 1975a, p. 75).

O programa é explícito nas suas diretrizes e fazia parte de um processo maior dentro do II PND de ampliação da base exportadora tendo em vista a nova conjuntura. Costa (2000, p. 64) inclusive aponta a mudança de rumos ocorrida em virtude do novo patamar da política econômica em consonância com a realidade global de crise, principalmente da dificuldade de investimentos e com vistas a atender os setores voltados à exportação. Nesse sentido o autor assevera:

Essa mudança repercutirá nas diretrizes do plano no que concerne às políticas territoriais, consubstanciadas em medidas agressivas relacionadas à expansão da fronteira econômica e ao tipo de ocupação econômica das chamadas "áreas vazias" do território. (COSTA, op. cit. p. 64).

Por áreas vazias eram consideradas pelos agentes hegemônicos aquelas habitadas por tribos indígenas e por uma população rural já residente. Com os governos militares sucederam dois processos: uma aceleração de um processo espontâneo de ocupação que já ocorria no Centro-Oeste e Norte do país a partir dos anos de 1950; e a definição das características da ocupação bem como do seu controle, pois além de um interesse econômico, havia um interesse geopolítico (MARTINS, 1997, p. 85-86).

No II PND surgiram programas importantes como o Programa de Desenvolvimento dos Cerrados (POLOCENTRO) e a parceria internacional efetuada entre o Brasil e o Japão, que dá origem ao Programa de Cooperação Nipo-Brasileira para o Desenvolvimento dos Cerrados (PRODECER), ao qual se tornou o programa com melhores resultados dentro do Cerrado na proposta de produção com novas bases técnicas e de base exportadora. Quanto aos programas, Calaça e Inocêncio (2010, p. 285) são categóricos em afirmar que:

[...] o POLOCENTRO e o PRODECER são os que assumem maior importância como elemento capaz de sustentar a tese de que o Estado é o principal ordenador territorial e foi o mais importante elemento da incorporação do Cerrado ao circuito produtivo capitalista nacional e internacional. 
As áreas de Cerrado, principalmente aquelas do Centro-Oeste, eram tidas como adaptáveis ao novo modelo produtivo de base técnica moderna. Possuíam uma população rarefeita e disponibilidade de terras propícias para a instalação de grandes empresas agropecuárias, principalmente na sua porção norte, já em áreas da Amazônia.

Inclusive o movimento de integração dessas áreas aprofundavam os desencontros entre os migrantes descapitalizados e os grandes empreendimentos favorecidos pelo governo, criando discussões acerca da questão agrária no bojo das disputas por terras na fronteira agrícola.

Martins (2003, p. 172) ilustra bem essa condição quando argumenta que a disputa pelas terras novas se converte como disputa entre dois modelos de ocupação econômica: a grande fazenda e a agricultura familiar, sendo que o "[...] primeiro modelo era viabilizado pelos subsídios, pela força e pela repressão.”.

Nesse contexto, a composição da estrutura fundiária da região Centro-Oeste caracterizava-se pela concentração de grandes propriedades rurais que atendiam plenamente aos interesses do Estado contidos nos planos já elencados, assim no intervalo entre as décadas de 1970 e 1980, período dos PNDs I e II (1972 a 1979) a condição fundiária estruturou-se conforme as estratégias governamentais, criando uma configuração territorial propícia para os interesses dos agentes hegemônicos. A configuração territorial aqui abordada deve ser compreendida como sendo o conjunto de "[...] sistemas naturais, herdados por uma determinada sociedade, e dos sistemas de engenharia, isto é, objetos técnicos e culturais historicamente estabelecidos." (SANTOS; SILVEIRA, 2004, p. 248).

A consolidação de uma estrutura agrária concentrada estava fundamentada na inexistência de uma política agrária explícita, e teve a sua essência mantida no bojo da política agrícola que influenciou decisivamente a manutenção do status quo no campo brasileiro. Para Delgado (2001, p. 25), “Um exemplo desse fenômeno é o que ocorreu no Brasil na década de 70, quando a política agrícola da modernização conservadora levou a um aumento da concentração da posse e da propriedade da terra no meio rural.”.

O autor ainda indica a existência de duas posições dicotômicas, de um lado existiriam os progressistas, ávidos de uma política agrária que entre outras reivindicações pudesse concretizar a reforma agrária, de outro os conservadores, defensores de políticas agrícolas 
relacionadas à modernização produtiva. Esse último grupo reage contra qualquer proposta pública de desconcentração da estrutura fundiária hegemônica no país.

Se considerarmos as atuais condições de concentração como resultado histórico e espacial das lutas de forças opostas, fica evidente o sucesso do segundo grupo, o conservador, ao conseguir impor seus objetivos, visto que a concentração da estrutura fundiária é uma realidade concreta.

Como o processo de ocupação e integração tinha como proposta a solidariedade com a expansão capitalista no Brasil, a condição de concentração fundiária cumpre a sua função e confirma os pressupostos de Oliveira (2007, p. 99) de que "a propriedade e a concentração da terra no capitalismo constituem-se em mecanismos de produção do capital." e também de Elias (2013, p. 211) ao assinalar que "As características da estrutura fundiária e dos regimes de propriedade da terra são fundamentais para a forma de difusão do capitalismo no campo.”.

Para a região Centro-Oeste essa era uma condição imprescindível para a consecução dos projetos de integração, com base na produção do tipo exportadora, cuja demanda por extensas áreas mostrou-se clara.

Na Tabela 1, é possível observar o nível de concentração fundiária existente na região Centro-Oeste, que é fruto das condições anteriormente expostas, ou seja, do projeto pensado e financiado pelo Estado e empreendido por uma parcela pequena de produtores a partir de uma racionalidade empresarial fomentada pelas novas relações postas.

Mas Oliveira (2007, p. 131-132) pondera que o que se convencionou chamar de modernização da agricultura não agiu para a transformação dos latifundiários em empresários capitalistas, porém do contrário "transformou os capitalistas industriais e urbanos, sobretudo do Centro-Sul do país, em proprietários de terra, em latifundiários.”. 
Tabela 1 - Área dos estabelecimentos agropecuários recenseados na região Centro-Oeste de 1970 a 2006

\begin{tabular}{|c|c|c|c|c|c|c|c|c|c|c|c|c|}
\hline & \multicolumn{2}{|l|}{1970} & \multicolumn{2}{|l|}{1975} & \multicolumn{2}{|l|}{1980} & \multicolumn{2}{|l|}{1985} & \multicolumn{2}{|l|}{1996} & \multicolumn{2}{|l|}{2006} \\
\hline & ha & $\%$ & ha & $\%$ & ha & $\%$ & ha & $\%$ & ha & $\%$ & ha & $\%$ \\
\hline Menos de 10 ha & 181.150 & 0,4 & 337.479 & 0,4 & 258.024 & 0,3 & 328.107 & 0,3 & 159.350 & 0,1 & 243.140 & 0,2 \\
\hline 10 a menos de 100 ha & 2.910 .133 & 7,0 & 3.616 .835 & 4,6 & 3.770 .693 & 4,0 & 4.416 .564 & 4,5 & 4.689 .518 & 4,3 & 6.344 .278 & 6,1 \\
\hline 100 a menos de 1000 ha & 12.487 .087 & 29,9 & 17.247.905 & 22,0 & 20.632 .538 & 21,8 & 23.209 .428 & 23,4 & 25.357.941 & 23,4 & 24.926 .659 & 24,0 \\
\hline 1000 ha e mais & 26.199 .063 & 62,7 & 57.314 .585 & 73,0 & 70.107 .454 & 74,0 & 71.168 .273 & 71,8 & 78.293 .170 & 72,2 & 72.283.251 & 69,6 \\
\hline Total dos recenseados & 41.777 .433 & 100 & 78.516 .804 & 100 & 94.768 .709 & 100 & 99.122 .372 & 100 & 108.499 .979 & 100 & 103.797 .328 & 100 \\
\hline
\end{tabular}

Fonte: IBGE, Séries históricas e estatísticas, 2014

No seu conjunto, a região Centro-Oeste apresentava condições naturais propícias para as atividades agropastoris pensadas nos projetos governamentais, contudo era extremamente carente das condições técnicas necessárias para dinamizá-la e que redundassem em uma evolução significativa da produção conforme fora projetada para essa região, ou seja, apresentava uma distinção da configuração territorial, com abundância dos sistemas naturais e precariedade dos sistemas de engenharia existentes.

Assim, as infraestruturas necessárias foram sendo sistematicamente instaladas pelo Estado dentro dos limites financeiros e das intenções políticas dos planos existentes, já que o Brasil aprofundara suas relações com os circuitos mais amplos do mercado mundial. Esses limites financeiros, principalmente após 1974, foram sendo contornados pelo uso reiterado de mecanismos de empréstimos, criando no período o crescimento com endividamento como aponta Xavier (2004, p. 336) com base em Castro (1985). O autor complementa o cenário dentro das políticas públicas afirmando que:

\footnotetext{
Esse crescimento seria gestado por intermédio do II Plano Nacional de Desenvolvimento (1974), priorizando a implantação de novos setores, a criação e a adaptação de tecnologias para modernizar a economia, o ajustamento às novas realidades da economia mundial e uma nova etapa de esforço para a integração nacional. (XAVIER, op. cit., 336).
}

O discurso da integração não podia se ausentar porque representava a ideologia do regime autoritário que se encontrava na situação de resolver os problemas internos. Nesse 
caso havia a exigência de modernização da base técnica produtiva em diversos setores, aliadas às novas demandas externas advindas da conjuntura internacional mediada pelas sucessivas crises que surgiam.

Dentro das ações direcionadas dentro do II PND para o Centro-Oeste, evidencia-se a preocupação em utilizar as áreas disponíveis a partir de duas estratégias: a primeira dentro da própria região e a segunda como estratégia para a ocupação da Amazônia. Caminho obrigatório para a ocupação da vastidão amazônica a partir da Região Concentrada, a malha rodoviária do Centro-Oeste estruturou-se a partir de um sistema de rodovias federais, rodovias estaduais e estradas vicinais, inicialmente de reduzido alcance e de precárias condições na sua maior parte. Caracterizava-se o Centro-Oeste em relação ao setor de transportes na década de 1970, pela sua pouca expressividade no conjunto nacional. Quanto às poucas vias rodoviárias, observa-se a ocorrência de três sistemas que podem ser observados no Quadro 1. Já no Mapa 1, destacamos o sistema de penetração e o sistema de apoio.

\section{Quadro 1 - Sistemas do transporte rodoviário do Centro-Oeste em 1970}

\begin{tabular}{|l|l|l|}
\hline Sistema de penetração & Rodovias federais & $\begin{array}{l}\text { BR-153 (Belém-Brasília) } \\
\text { BR-163 (Cuiabá-Santarém) } \\
\text { BR-158 }\end{array}$ \\
\hline Sistema de apoio & Rodovias federais & $\begin{array}{l}\text { BR-070 (Brasília-Cuiabá-Cáceres) } \\
\text { BR-364 }\end{array}$ \\
\hline Sistema alimentador & $\begin{array}{c}\text { Rodovias estaduais e } \\
\text { estradas vicinais }\end{array}$ & $\begin{array}{l}\text { São diversas vias que fazem a ligação } \\
\text { interna entre os municípios de cada } \\
\text { estado com os demais sistemas } \\
\text { rodoviários }\end{array}$ \\
\hline
\end{tabular}

Fonte: II Plano Nacional de Desenvolvimento, Programa de Ação do Governo para a Região Centro-Oeste (1975-1979), (1975) 


\section{Mapa 1 - Rodovias de penetração e de apoio que atravessam a região Centro-Oeste}



Fonte: Departamento Nacional de Infraestrutura de Transporte - DNIT, (2014)

De acordo com o Programa de Ação do Governo para a Região Centro-Oeste para o período de 1975-1979, essa região foi estrategicamente pensada como área produtora de alimentos, com ênfase para investimentos na agropecuária e, ainda, a partir da criação de Brasília passou a ser tida como a principal via de ocupação "racional" da Amazônia. (BRASIL, 1975a). 
Era no sentido Sul-Norte que a Amazônia seria ocupada, a partir das vias de penetração, com as grandes levas de migrantes que passavam pelo Centro-Oeste que poderiam ser absorvidas permanentemente ou temporariamente. Assim, a criação de várias cidades que ocorreram ao longo das rodovias federais a partir da década de 1970 evidencia a realização dessa perspectiva. Uma análise pormenorizada desse processo será feita no capítulo 4, que trata da produção do espaço urbano mato-grossense.

Na discussão acerca das ações voltadas para a integração das áreas periféricas ao conjunto da economia nacional, alguns programas tiveram um efetivo impacto na reestruturação territorial do Centro-Oeste, tendo o estado de Mato Grosso recebido investimentos diretos que proporcionaram essa reestruturação frente aos objetivos propostos, criando uma especialização produtiva que se consolida nas décadas seguintes aos anos de 1970-1980.

Os programas especiais buscavam concretizar as propostas de criar uma nova configuração territorial a partir das condições naturais e sociais consubstanciada pelas inversões técnicas. As ações foram efetivadas principalmente durante os períodos em que as condições financeiras do Estado puderam sustentar a sua execução, posteriormente observa-se movimentos em busca de parcerias, com o capital privado nacional e internacional, para prosseguir com o projeto de integração econômica face às novas condições que surgiam.

\subsubsection{Os programas especiais com repercussões diretas no Centro-Oeste}

Partindo dos planos nacionais de desenvolvimento, que determinaram ações gerais para criar as condições de integração territorial e econômica, foram criados diversos programas, com abrangência em diversas escalas, que repercutiram diretamente nas regiões brasileiras. Para a região Centro-Oeste alguns programas foram fundamentais para determinar uma nova condição de integração e crescimento.

De acordo com Abreu (2001, p. 86) o Plano de Desenvolvimento Econômico-Social do Centro-Oeste (PLADESCO) foi elaborado pela Superintendência de Desenvolvimento do Centro-Oeste (SUDECO) após a realização de estudos prévios e era voltado para ações de médio e de longo prazo, de acordo com as metas nacionais. Essas metas previam a ampliação 
do mercado e o crescimento sistemático da produção de produtos como minérios e soja, voltados à exportação.

Com isso foram selecionadas treze áreas-programa, que receberam recursos específicos. Os estudos efetuados dentro do PLADESCO estimularam os programas especiais que foram implantados pela SUDECO a partir do II PND em 1974. Buscava-se eleger áreas:

[...] tanto de potenciais como de estrangulamento, que pudessem exercer o papel de pólos de desenvolvimento, onde seriam implementados os investimentos, tendo em vista a função que caberia a cada uma delas, dentro dos objetivos nacionais e dos interesses do tripé (capital privado nacional, multinacionais e Estado). (ABREU, 2001, p. 87)

O Quadro 2, a seguir, proposto por Silvana Abreu a partir de dados do Ministério do Interior e da SUDECO no ano de 1973, é revelador da convergência dos interesses nacionais, caracterizados como sendo as prioridades nacionais, com as ações a serem efetuadas no interior dos programas específicos de caráter regional.

Assim, a localização das áreas-programas, onde as ações seriam efetuadas, era escolhida de acordo com os critérios de potencial ou de estrangulamento.

Quadro 2 - PLADESCO compatibilizado com as metas nacionais

\begin{tabular}{|l|l|l|l|}
\hline $\begin{array}{l}\text { Prioridades } \\
\text { Nacionais }\end{array}$ & $\begin{array}{l}\text { Programação } \\
\text { Regional }\end{array}$ & Tipo de área & \multicolumn{1}{|c|}{ Localização } \\
\hline $\begin{array}{l}\text { Integração } \\
\text { nacional }\end{array}$ & $\begin{array}{l}\text { Incorporação de } \\
\text { novas áreas de } \\
\text { produção }\end{array}$ & $\begin{array}{l}\text { Área de } \\
\text { incentivo }\end{array}$ & $\begin{array}{l}\text { Aripuanã, Peixoto, Xingu e } \\
\text { Cáceres (em Mato Grosso); } \\
\text { Ji-Paraná (em Rondônia); } \\
\text { Gurupi e Araguaína (em Goiás) }\end{array}$ \\
\hline $\begin{array}{l}\text { Migrações } \\
\text { internas }\end{array}$ & $\begin{array}{l}\text { Fixação de } \\
\text { populações e } \\
\text { desenvolvimento } \\
\text { urbano }\end{array}$ & $\begin{array}{l}\text { Area de } \\
\text { fixação }\end{array}$ & $\begin{array}{l}\text { Regiâa Centro-Oeste } \\
\text { (principalmente Paranã, em } \\
\text { Goiás) }\end{array}$ \\
\hline $\begin{array}{l}\text { Corredor de } \\
\text { exportação }\end{array}$ & $\begin{array}{l}\text { Tecnificação da } \\
\text { agropecuária, } \\
\text { industrialização } \\
\text { da produção }\end{array}$ & $\begin{array}{l}\text { Área de } \\
\text { exportação }\end{array}$ & $\begin{array}{l}\text { Cuiabá-Rondonópolis, } \\
\text { Corumbá e Campo Grande- } \\
\text { Dourados (em Mato Grosso); } \\
\text { Ceres-Anápolis e Rio Verde- } \\
\text { Itumbiara (em Goiás) }\end{array}$ \\
\hline
\end{tabular}

Fonte: ABREU, Silvana de. (2001)

Abreu (2001, p. 89) esclarece que nas áreas de incentivos havia o propósito de incorporação de novas áreas, com políticas de colonização atreladas à produção agrícola, principalmente no norte da região Centro-Oeste com recursos da Superintendência de 
Desenvolvimento da Amazônia (SUDAM), excetuando-se Cáceres. Para os corredores de exportação foram escolhidas as áreas que já tinham produção relevante e necessitavam dos eixos de transportes. Quanto às áreas de fixação, apesar de serem direcionadas à região como um todo, priorizou o Paranã face ao entorno de Brasília.

De acordo com Peixinho (2006, p. 151-152) o PLADESCO foi gerado na concepção de desenvolvimento regional, e além de investir na estrutura viária, efetuou intervenções no ordenamento urbano e desenvolveu ações mais amplas que o POLOCENTRO, cuja prioridade era a indução técnica a setores de atividades econômicas específicas, ou seja, selecionados previamente pelo programa. Por favorecer a implantação de infraestruturas nas áreasprograma, criou as bases de apoio para a implantação posterior do POLOCENTRO que se efetivou a partir de 1975.

Segundo Brasil (1975b) o Decreto $\mathrm{n}^{\circ} 75.320$ de 29 de janeiro de 1975 criou o Programa de Desenvolvimento dos Cerrados (POLOCENTRO), durante o governo do presidente Ernesto Geisel, com o objetivo de promover o desenvolvimento e a modernização da base produtiva da agropecuária em duas áreas bem delimitadas, no Centro-Oeste e no Oeste de Minas Gerais. Esse processo se daria a partir de uma ocupação racional das áreas previamente selecionadas que eram cobertas por Cerrado.

No Centro-Oeste, as áreas que seriam abrangidas pelo programa foram assim distribuídas:

- Em Mato Grosso no eixo entre Campo Grande-Três Lagoas (ao longo da Estrada de Ferro Noroeste, entre as duas cidades); Bodoquena (ao longo da rodovia de ligação entre Aquidauana e Bonito); Xavantina (delimitada pelo rio Cristalino e ribeirão Água Preta) e Parecis (localizada ao longo da BR-364, entre os ribeirões Sumidouro e Sacré); posteriormente, em 1979, foi incluído o eixo Cuiabá-Rondonópolis.

- No estado de Goiás: Gurupi (ao longo da BR-153, entre as localidades de Gurupi e Porangatu); Paranã (ao longo da BR-020, entre o rio Paraim e a cidade de Posse); Pirineus (ao longo da BR-080, entre a divisa do Distrito Federal com Goiás e do rio das Almas); Piranhas (ao longo da BR-158, entre Piranhas e Aragarças) e Rio Verde (localizada entre os rios Verde Grande e Claro e o eixo da BR-060).

Definidas as áreas, a busca pela modernização da base produtiva da agropecuária dependia da implantação e disseminação de um pacote tecnológico que permitisse o aumento 
na produtividade sob o signo da nova racionalidade. Segundo Silva (2000, p. 25-26) o desenvolvimento de novas tecnologias para o Cerrado foi gestado a partir de um conjunto de programas, cujos destaques são: Programa de Assentamento Dirigido do Alto Paranaíba (PADAP), restrito ao território mineiro por ser um programa estadual; o POLOCENTRO e o PRODECER, esses dois últimos vinculados ao governo federal.

Para Pires (2000, p. 120) o POLOCENTRO materializou outra forma de intervenção estatal efetivada para viabilizar o desenvolvimento agrícola no Cerrado, aproveitando-se das experiências do Programa de Crédito Integrado (PCI - 1972) e do PADAP, que foram criados pelo governo de Minas Gerais. O programa foi criado em 1975 pelo governo federal, sob a égide do II PND, e tinha o objetivo de incorporar racionalmente, ou seja, em bases empresariais, mais de três milhões de hectares, sendo 1,2 milhão com a pecuária, 1,8 milhão em lavouras e 0,7 milhão em reflorestamento.

Foram aplicados cerca de 860 milhões de dólares, distribuídos nos seguintes setores: transporte, pesquisa e agropecuária, armazenamento, energia, assistência e crédito rural. Não apresentou repercussão positiva na estrutura ocupacional, já que não houve incremento de mão de obra, apesar das grandes áreas ocupadas pelas ações do programa.

$\mathrm{O}$ autor finaliza apontando que o POLOCENTRO se transformou em reforço " [...] às condições estruturais de desigual distribuição de terras e de renda nas regiões onde atuou, não oferecendo alternativas para atingir, na origem, o problema da ocupação e da migração rural.” (PIRES, 2000, p. 121).

Não resta dúvida que o conjunto de programas governamentais, desde o Plano de Metas aos governos militares da ditadura, intencionava uma integração econômica e implantação de uma estrutura produtiva que permitisse ao país consolidar-se como potência regional.

Para efetivar esse anseio, a imensa porção de terras da área de Cerrado, nas franjas da região mais dinâmica e no caminho à ocupação da Amazônia, apresentava-se como possibilidade bem concreta de estabelecer um novo padrão racional, afastando-se do modelo produtivo do meio rural tradicional. O campo seria gerido como uma empresa.

Como já apontamos anteriormente, a ocupação dos denominados espaços vazios pressupunha a inexistência de uma população residente. Mas não era esse o caso, pois a existência de nações indígenas e comunidades tradicionais nas regiões do Cerrado implicavam 
não na sua inexistência, mas no fato de não estarem em consonância com os projetos propostos. Assim, a produção e reprodução social desses grupos, apesar da maior adequação ao meio natural eram consideradas como contra-racionalidades.

De acordo com Santos (2008, p. 309):

Essas contra-racionalidades se localizam, de um ponto de vista social, entre os pobres, os migrantes, os excluídos, as minorias; de um ponto de vista econômico, entre as atividades marginais, tradicional ou recentemente marginalizadas; e, de um ponto de vista geográfico, nas áreas menos modernas e mais "opacas", tornadas irracionais para usos hegemônicos.

Àqueles não sincronizados com a nova condição imposta, de base empresarial, restava a resistência isolada, com pouco efeito, não se constituindo como entrave para a o processo em si. Para as resistências o conjunto Estado-Mercado adotava estratégias diversas, inclusive com o extermínio, caso de diversas nações indígenas ocupantes das áreas de Cerrado e de floresta da região Centro-Oeste, ou a cooptação dos posseiros, meeiros e trabalhadores rurais como estoque de mão de obra para atender o novo regime de trabalho, além da integração compulsória como mercado consumidor.

Monteiro (2004, p. 94-95) assinala que as estratégias do POLOCENTRO se voltavam, sobretudo, para atrair empresários para o campo, principalmente produtores do eixo SulSudeste para as áreas de Cerrado. Criou-se uma linha própria de financiamento destinada a adquirir equipamentos para as patrulhas mecanizadas para o preparo inicial do solo, evitando maiores dispêndios para os produtores com investimentos em máquinas.

Mas, ao priorizar os aspectos econômicos por conta dos interesses de aumentar a competitividade dos produtos primários no Cerrado, em meio ao cenário de crise, o programa desconsiderava os aspectos sociais.

A lógica do programa era fortalecer uma commodity que criasse um novo ciclo, como já houvera no passado, e não fomentar a agricultura tradicional praticada no interior do país.

A agricultura tradicional, principalmente aquela voltada à subsistência das unidades familiares residentes no meio rural, não interessava porque se buscava a especialização das unidades produtivas. 
Assim, como ocorrera com a produção industrial, promovia-se no campo uma reorganização rumo a uma especialização funcional. Um exemplo notável foi a implantação da cultura da soja que foi sendo disseminada sistematicamente pelas áreas de Cerrado, pois se adequava aos novos parâmetros pela necessidade de insumos a montante e a jusante do processo produtivo.

Esses insumos compunha o pacote tecnológico da Revolução Verde e implicava a presença maciça de capital para a sua aquisição, logo era seletivo quanto ao nível de capitalização do produtor.

Para Duarte (1988a, p. 18) a intervenção do poder federal, por meio de estratégicas econômicas, intensificou-se no período de 1975 a 1979 com os programas especiais inseridos no II PND, como o POLOCENTRO, resultando na modernização da “[...] agricultura de Mato Grosso do Sul e de Goiás, transformando-a numa agricultura capitalista. Permitiu, igualmente, a ampliação da área cultivada e expansão da cultura de grãos de Mato Grosso”.

O autor destaca também os programas mais localizados, como o Programa de Desenvolvimento da Região da Grande Dourados (PRODEGRAN), o Programa de Desenvolvimento do Pantanal (PROPEPAN) que foram direcionados para as áreas de Mato Grosso do Sul, sendo que o segundo também abrangeu as áreas pantaneiras de Mato Grosso, e o Programa de Polos Agropecuários e Agrominerais da Amazônia (POLAMAZÔNIA) com expressiva repercussão no Norte de Mato Grosso.

A abrangência dos programas pode ser constatada por meio da Figura 1, que apresenta a representação espacial de acordo com a obra de Duarte (1988b) sobre a estrutura do espaço regional da região Centro-Oeste. 
Figura 1 - Áreas de abrangência de programas federais selecionados

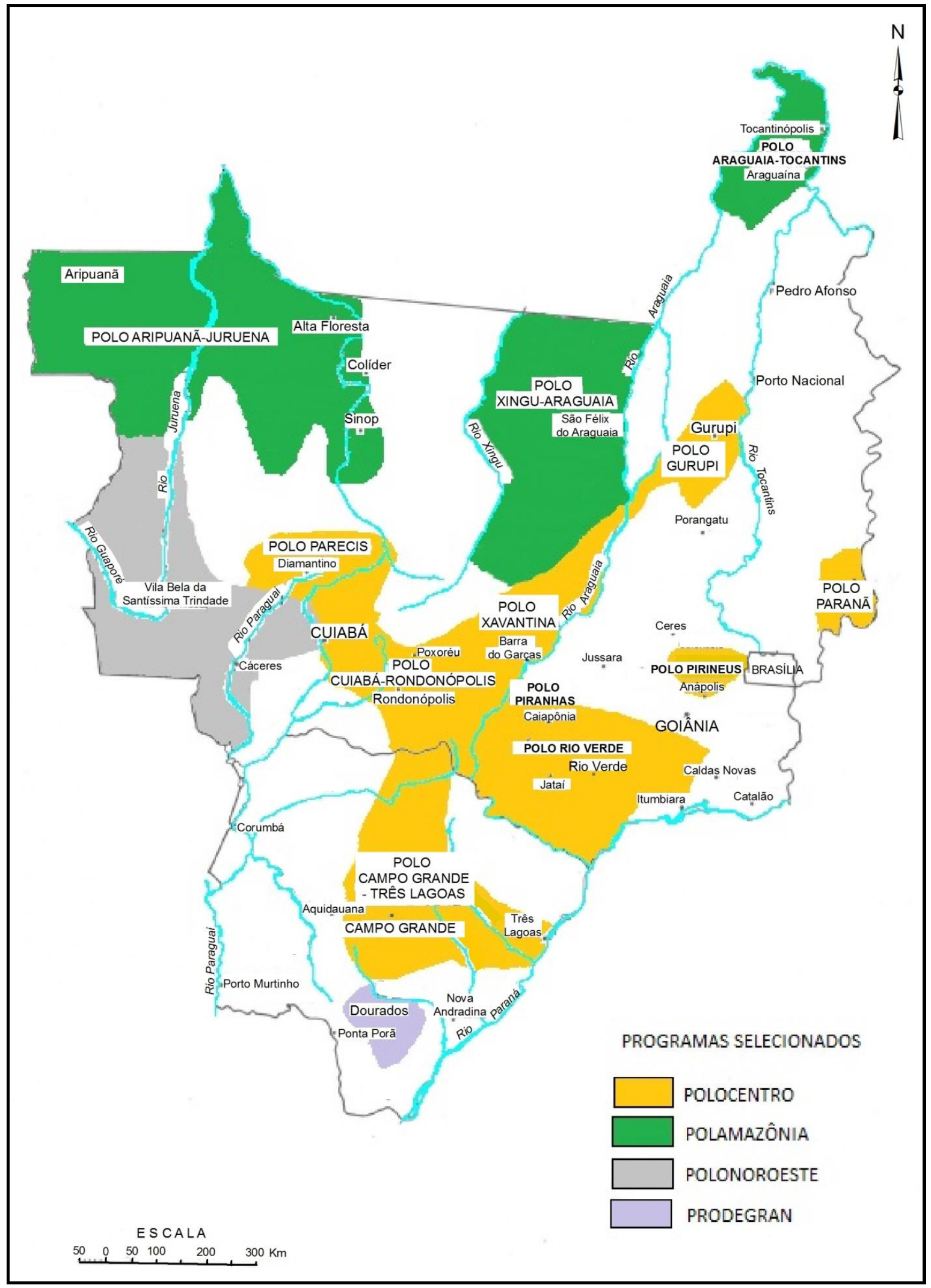

Fonte: DUARTE, A. Capdeville (1988b)

Organização: LIMA, Ronei C. de (2014) 
Discutindo a participação do Estado no projeto modernizador da região Centro-Oeste, Negri (2001) apoia-se em Redwood III e Barreto (1984) para informar que através do I PND, e seus programas especiais PIN, Programa de Redistribuição de Terras e de Estímulo à Agroindústria do Norte e do Nordeste (PROTERRA) e Programa de Desenvolvimento do Centro-Oeste (PRODOESTE), a intervenção estatal fica explícita. E enquanto os primeiros, (PIN e PROTERRA) têm suas ações restritas à parte dessa região compreendida à Amazônia Legal, o PRODOESTE volta-se para a consolidação da infraestrutura e para o apoio às atividades produtivas não atendidas pelos demais programas. Vias importantes, como as rodovias que ligam Cuiabá à Campo Grande e Dourados e Cuiabá a Jataí, passando por Rondonópolis, são exemplos de importantes ligações consolidadas nesse programa.

No mesmo sentido, Abreu (2001) ratifica que enquanto o PIN oferecia subsídios para os investimentos privados efetuados na Amazônia Legal, que abrangia o Norte de Mato Grosso e Goiás e objetivava estabelecer os eixos de integração - representados pelas rodovias Transamazônica e Cuiabá-Santarém -, o PRODOESTE voltava-se para a ampliação da rede rodoviária regional. A proposta, segundo a autora, fazia parte do conjunto de realizações nacionais, proposto para o período de 1972/1974, explicitando o papel agropecuário dessa parte da Amazônia e da região Centro-Oeste.

É importante termos claro que entre os estados do Centro-Oeste, Mato Grosso - após a divisão territorial -, apresentava a maior precariedade em relação às vias de ligação com a área dinâmica localizada no eixo Sul-Sudeste, pois Goiás e o Sul de Mato Grosso, atual estado de Mato Grosso do Sul, já possuíam um sistema de transportes mais articulado, assim como o Distrito Federal. Essa condição, apesar das intervenções estatais, ainda prevalece, caracterizando a incompletude da estruturação do sistema de transportes para essa área do país.

As estratégias para consolidar a modernização do campo e a intensificação da fluidez eram repetidas nos sucessivos planos e programas na década de 1970. Assim, enquanto o POLOCENTRO estava em curso, o governo militar já gestava um novo acordo, com o Japão, que redundou na criação do Programa de Cooperação Nipo-Brasileira para o Desenvolvimento dos Cerrados (PRODECER), visando dar continuidade à integração das áreas de Cerrado à base modernizada da agricultura. 
Além do interesse público em parcerias com o setor privado, algumas dificuldades do POLOCENTRO também favoreceram a sua substituição por um programa de maior controle no melhoramento da técnica produtiva.

Para Peixinho (2006, p. 155), o POLOCENTRO, cuja diretriz era induzir os produtores que se enquadravam nas garantias exigidas ao novo modelo técnico-produtivo, não inferiu a transição esperada. Isso decorreu pelo fato de serem os grandes pecuaristas tradicionais os mais aptos a aderir ao plano, porém a migração da pecuária para a produção de grãos não se efetivou como o esperado, havendo um predomínio da pecuária nas novas áreas incorporadas pelo programa. Somente em Mato Grosso as áreas de agricultura superou a de pecuária, portanto, “[...] é preciso reconhecer que o POLOCENTRO, ao contrário do que se acredita, beneficiou em primeiro lugar e diretamente os pecuaristas tradicionais.".

Segundo Pessôa (1988), no bojo da modernização dos meios e instrumentos de produção, necessários ao aumento da produtividade agrícola, o Estado brasileiro buscava ampliar as bases de investimentos com participação do capital estrangeiro na implantação de empresas agropecuárias. Nesse ínterim, surge o acordo que origina o PRODECER, conhecido também como Projeto Cerrado, com impacto direto no Cerrado de Minas Gerais.

A criação do Centro de Pesquisa Agropecuária do Cerrado (CPAC) vinculado a Empresa Brasileira de Pesquisa Agropecuária (EMBRAPA) - criada em 1973 no âmbito do I PND (CALAÇA; INOCÊNCIO, p. 285, 2010) -, com participação efetiva do POLOCENTRO e em consonância com as metas do II PND indica o caminho escolhido.

As pesquisas foram direcionadas para uma cultura que permitisse um retorno econômico maior e uma integração com o setor industrial. A cultura escolhida foi a soja que causou “a revolução agrícola no cerrado, na década de 1970.” (PESSÔA, 1988, p. 99).

Monteiro (2004) ressalta que a década de 1970 foi pródiga na concessão de crédito voltado para o desenvolvimento técnico da base produtiva, cabendo à EMBRAPA, por meio de recursos humanos e pesquisas, produzir o conhecimento para estabelecer a produção mais favorável dentro das metas do POLOCENTRO. Assim, temos o estabelecimento de quatro centros de pesquisas para a área do POLOCENTRO, sendo feita a articulação com empresas estaduais de pesquisas sob a coordenação da EMBRAPA.

A atuação da EMBRAPA era de suporte para a difusão de melhorias técnicas das produções tradicionais bem como inferir novas culturas de acordo com os projetos 
agropecuários. Esses projetos estavam inseridos nos diversos programas especiais que tiveram atuação na Região Centro-Oeste e principalmente em Mato Grosso antes da divisão políticaadministrativa. Destaca-se o apoio dessa empresa de pesquisa para os seguintes programas: POLOCENTRO, PRODEPAN, PRODEGRAN e POLAMAZÔNIA conforme atesta Abreu (2001). A autora informa que esses programas estavam sob os auspícios da SUDECO no contexto do "Brasil-Potência".

Considerando a abrangência das ações, nos aproximamos de uma organização das políticas territoriais do Estado brasileiro que são interdependentes e que objetivam processos mais amplos. Assim, teríamos:

a) Políticas de amplitude nacional, representada pelos planos nacionais - (PIN) de integração, e (PND) de desenvolvimento - indicavam as metas que deveriam ser cumpridas dentro dos prazos de vigência;

b) Políticas de amplitude regional, que constavam nos planos nacionais e possuíam órgãos gestores, como a Superintendência de Desenvolvimento da Amazônia (SUDAM) que investiu em áreas de Mato Grosso e Goiás, e a Superintendência de Desenvolvimento do Centro-Oeste (SUDECO) com ações direcionadas a toda região Centro-Oeste;

c) Política de pesquisa e desenvolvimento, que no caso do setor agrícola teve a base de pesquisas a cargo da EMBRAPA e das congêneres estaduais, que podem ser consideradas como "subvenções diretas" do Estado em favor do desenvolvimento capitalista, como atesta Mandel (1982, p. 388);

d) Políticas de amplitude regional e/ou local, com ações mais específicas por setores em que constam programas como: POLOCENTRO, PRODOESTE, PRODEGRAN, PRODEPAN, PRODECER, que efetivavam as ações, dentro dos limites técnicos e financeiros.

No conjunto, eram os instrumentos com os quais o Estado preparava o território para a continuidade da expansão capitalista no Brasil em conjunto com a perspectiva de integração que segundo Arrais (2013, p. 23) pode ser também entendida como um eufemismo de subordinação -, ao sistema de mercado nacional e global; e de ocupação, em detrimento dos ocupantes já existentes.

A proposta no discurso de integração nacional, premente nos anos de 1970, também revela a condição da territorialidade na construção do autoritarismo brasileiro. Para a ascensão 
como potência regional, era necessário ocupar os espaços vazios que seriam incorporados ao domínio da nação, revelando o caráter geopolítico da modernização almejada. Assim, temos o território como elemento primordial para a mediação entre Estado e sociedade, pois se tratava de "[...] um recurso simbólico de formação do indivíduo coletivo, em detrimento de uma comunidade nacional de cidadãos.” (BECKER; EGLER, 1993, p. 34).

Junto às bases voltadas para os projetos de Brasil-potência, Brasil-grande, de viés progressista - tendo em vista a aversão ao arcaico e focado no novo, na modernidade -, verifica-se uma sincronia com as elites, sejam elas progressistas ou conservadoras. Nesse contexto, a região Centro-Oeste serviu de campo de experimentação, de investimentos e da criação de uma nova configuração territorial.

A dinâmica das alterações sofreu forte impacto com os desdobramentos de um movimento maior, de fundo, que implicava em uma reorganização capitalista sobre novas bases de acumulação e de regulação. Destarte, em sincronia com as sucessivas crises, apesar do esforço de endividamento levado a cabo pelo Estado brasileiro, o financiamento dos processos de estruturação do território passava a apresentar sucessivas reduções, culminando nos anos de 1980 em um quadro distinto do período compreendido pelos anos de 1960-1970.

Calaça e Inocêncio (2010, p. 287) apontam as dificuldades do Estado de manter os planos de desenvolvimento em virtude das condições econômicas adversas, assim:

O III PND, previsto para ser implantado em fins de 1979, não se desenvolveu, pois o Brasil passou a enfrentar sérias dificuldades de financiamento, comprometendo a sua capacidade de colocar em prática os programas de desenvolvimento econômico.

Apesar de considerada por muitos como a década perdida, em virtude das dificuldades financeiras inerentes ao endividamento, ao baixo crescimento econômico, aos ajustes efetivados para atender ao disciplinamento fiscal e de combate à inflação; e perversa, pelo arrocho às camadas menos favorecidas, tanto das cidades como do campo, não devemos nos esquecer dos ganhos políticos com a redemocratização que também se deram neste período.

O Estado apresentava limites fiscais que engessavam suas ações de reestruturação do território frente às demandas existentes. Ao mesmo tempo, as ações já efetivadas na década de 
1970, com a criação de infraestruturas em setores importantes, como o de transportes, energia, telecomunicações e de um ideário de modernidade vinculado às novas técnicas, como a que foi disseminada no setor agrícola nas áreas de Cerrado, provocaram uma simetria com a dinâmica da globalização que se aprofundara.

Santos e Silveira (2004, p. 253-254) constatam dois processos simultâneos a contar principalmente a partir dos anos 1980 uma “[...] difusão da nova modernidade, com uma dispersão no território de indústrias dinâmicas, de uma agricultura moderna e do respectivo setor de serviços.” Assim constituiu-se, a partir dessa divisão do trabalho mais dispersa no território, um centrifuguismo. Ao mesmo tempo, a necessidade de uma cooperação da base dispersa exige informação especializada, cujo lócus é a Região Concentrada, nessa região destaca-se o Sudeste e, com maior centralidade, a metrópole paulistana. Temos aí o centripetismo.

A agricultura moderna, de que fala Milton Santos e María Laura Silveira, foi bastante favorecida na década de 1970, pois o Estado adotou uma série de mecanismos importantes, como:

a) a criação de infraestruturas de transporte e armazenagem;

b) a pesquisa de novas variedades e de adequação das existentes à produção, como no caso do bioma Cerrado;

c) a política de crédito agrícola, que se volta para os setores produtivos de exportação.

Segundo Delgado (2001, p. 46-47), nos anos de 1970 o cenário internacional favorável estimulou a produção para exportação e, ao mesmo tempo, houve um aumento da renda interna refletida no PIB total per capita. Mas, a produção para o abastecimento interno não acompanhou esse crescimento da renda. Cria-se, assim, um paradoxo, cuja explicação é que o crédito agrícola era altamente representativo para o setor agrícola e como se voltava à produção para exportação, tornava-o mais rentável. Ao mesmo tempo, a produção para o consumo interno não era incentivada.

Para os anos de 1980, o autor é enfático em demonstrar a condição de crise que se consolida: 
[...] o desempenho do comércio internacional, especialmente na sua primeira metade, foi bastante desfavorável - devido à crise do mercado mundial: queda de preços, queda de volume de comércio, deterioração dos termos de troca - e o PIB total per capita teve um desempenho medíocre: cresceu à taxa média anual de $0,8 \%$ entre $1980 / 89$, o que levou a que essa década fosse considerada por muitos como uma "década perdida". (DELGADO, op. cit., 46-47).

Porém, a produção voltada à exportação mantém o crescimento, apesar de apresentar um ritmo menor, por conta da intervenção do Estado na política cambial e dos subsídios para as exportações. Nesse período, a produção voltada para o abastecimento interno se recupera, pela intervenção pública - política de preços mínimos e compras do governo federal - e pela "desova de inovações tecnológicas realizadas por organismos governamentais (e alguns privados)" que permitiram um acréscimo nos rendimentos físicos das culturas de abastecimento interno. (DELGADO, op. cit., p. 47).

O termo desova, usado pelo autor é sintomático da condição da produção de gêneros alimentícios voltados para o consumo interno no Brasil, pois o seu fomento se dá em condições bem diferentes do que ocorre com a produção das commodities agrícolas, cuja atenção do poder público se mantém até os dias hodiernos. Quanto à produção voltada à exportação, o apoio do Estado, fundamental para a estruturação necessária à sua manutenção e expansão, passa a enfrentar as condições adversas do mesmo mercado que o governo tanto insistiu em integrar. O controle das condições de mercado, em bases internacionais, exigia um aumento de competitividade, seja na produção em si, ou como vimos, a partir de políticas específicas, como a de câmbio.

Em relação às infraestruturas demandadas pela integração econômica observa-se um quadro de estagnação dos investimentos, tanto na criação como na manutenção. Barat (2011, p. 229) entende que passa a ocorrer, a partir dos anos de 1980, um "desmoronamento do Estado desenvolvimentista", pois houve o impacto direto da crise fiscal e uma "redução drástica da capacidade do setor público em financiar investimentos.”, tendo como resultado o fim de uma expansão contínua da oferta de infraestruturas disponibilizada por mais de trinta anos. Esse quadro se estende, pelos anos de 1990, como desdobramentos da crise interna, cujos desafios inflacionários e da dívida implicavam em esforços imediatos, reduzindo o planejamento de longo prazo. 
Nessa nova conjuntura de realinhamento do Estado ao cenário que emergia e no curso da disseminação do neoliberalismo, uma nova realidade se consolida.

Dentro dessa nova dinâmica, discutiremos a retomada das ações públicas voltadas à reestruturação do território brasileiro, com ênfase para a região Centro-Oeste e principalmente para os rebatimentos ocorridos no estado de Mato Grosso. O novo contexto se estrutura no seio das políticas que estabeleceram os Eixos Nacionais de Integração e Desenvolvimento (ENIDs) e o Plano Nacional de Logística de Transportes (PNLT).

\subsubsection{Os Eixos Nacionais de Integração e Desenvolvimento (ENID)}

O Estado brasileiro, principal agente de estruturação do território, passou a enfrentar uma condição interna de deterioração da capacidade de investir na consecução da infraestrutura necessária à continuidade do projeto de integração nacional junto aos mercados nacional e internacional. A conjuntura interna de crise fiscal, somada ao cenário externo de reorganização do sistema de mercado em meio às sucessivas crises, levaram os anos de 1980, e parte dos anos de 1990, a uma condição de paralisia quanto à efetividade dos projetos de planejamento territorial.

As ações pretéritas de cunho desenvolvimentista não tiveram continuidade e a precarização do que havia sido construído aumentava o que se convencionou chamar de custo Brasil. A retomada dos planos dependia do sucesso dos sucessivos ajustes econômicos, derivados dos diversos planos executados (Plano Cruzado, Plano Bresser, Plano Verão, Plano Collor I e II, Plano Real) cujos objetivos maiores eram a estabilização da economia e a retomada do crescimento.

A estabilização da economia ocorre a partir do Plano Real, de 1994, no governo de Itamar Franco que havia substituído o então presidente Fernando Collor após a sua queda. $\mathrm{O}$ governo de Fernando Henrique Cardoso, que sucede Itamar Franco, lança no Plano Plurianual (PPA - de 1996-1999) o "Programa Brasil em Ação" em que o conceito de eixos nacionais de integração e desenvolvimento surge como norteador principal. Segundo Souza (2011, p. 404405), o programa tinha como proposta traçar uma estratégia de desenvolvimento para o país 
que favorecesse a redução dos desequilíbrios regionais e sociais sob um novo prisma, ou seja, "sem considerar para efeito do planejamento, os limites dos Estados e regiões.".

Calaça e Inocêncio (2010, p. 287-288) complementam informando que o "Programa Brasil em Ação" apresentou como principais características a formação de parcerias entre o governo federal, os estados, os municípios e o setor privado; e tendo os eixos de desenvolvimento como referência espacial e geográfica. Esse período "representou o auge do processo de modernização agrícola e desenvolvimento da agroindústria. Foi o período de maior privatização das empresas públicas.”.

A região Centro-Oeste, preparada por diversos planos governamentais para constituirse em grande área produtora de commodities, continuou fazendo parte das estratégias do "Programa Brasil em Ação" na condição de área receptiva às agroindústrias, tendo em vista a grande produção agropecuária propiciada pelas ações de cunho modernizador em curso desde meados da década de 1970 .

Como pode ser observado em Brasil (1996a) a Lei no 9.276, de 9 de maio de 1996, que cria o PPA (1996-1999) deixa claro, no conjunto da estratégia de modernização produtiva, as seguintes diretrizes de ação do governo que ilustram essa parte importante do programa:

- $\quad$ modernização e ampliação da infraestrutura;

- $\quad$ aumento da participação do setor privado em investimentos para o desenvolvimento;

- fortalecimento de setores com potencial de inserção internacional e estímulo à inovação tecnológica e à restruturação produtiva;

- $\quad$ melhoria educacional, com ênfase na educação básica; e

- $\quad$ modernização das relações trabalhistas.

Excetuando-se o item que trata da melhoria educacional, que é a condição social do programa nessa estratégia, fica evidente o direcionamento neoliberal, com maior participação do setor privado no conjunto de ações a serem desenvolvidas dentro do programa e a proposta de uma modernização das relações trabalhistas. Inclusive nos objetivos destacados para a área do trabalho consta a "modernização da legislação trabalhista". Entendemos essa questão como estratégia para contornar os direitos contidos na Consolidação das Leis Trabalhistas (CLT), cujo conteúdo não se enquadra aos novos parâmetros pretendidos, inclusive de maior flexibilidade. Da mesma forma, fica explícito a ênfase à extroversão do modelo produtivo, cuja diretriz busca a inserção internacional. 
Araújo (1999, p. 14-15) ao discutir as escolhas estratégicas para os anos de 1990, chama a atenção para a prioridade dada à "integração competitiva" como política de médio prazo, resultando no "aprofundamento da internacionalização da economia do País" tendo como eixo principal a internacionalização financeira. Já na esfera produtiva ocorre uma alteração importante, pois se reduz a ênfase até então dada à integração do mercado nacional, e "[...] passa-se a priorizar a inserção no mercado mundial das empresas, segmentos e espaços econômicos mais competitivos.".

No mesmo sentido, Cano (2011, p. 37-38) argumenta que o Estado brasileiro abandona a opção por “[...] uma verdadeira Política de Desenvolvimento Regional” criando em 1995 a política baseada nos "Grandes Eixos”, os quais se tornariam os vetores de ligação entre as zonas produtivas e os portos, recebendo aportes financeiros com vistas a melhorar o desempenho exportador. Contudo, lembra que esses vetores serviriam apenas para a ligação entre "[...] pontos de origem-destino, e pouco ou nada fariam em prol dos maiores espaços regionais em que estivessem inseridos, e nem tratavam dos problemas urbanos e sociais das cidades maiores por eles envolvidas.".

As intenções por parte dessa política estava bem nítida e se esforçava para criar as condições de eficiência e competitividade exigidas no mercado internacional. As condições de assimetrias entre as regiões permaneciam e o Estado, com a postura neoliberal que lhe era própria nesse período, buscava ampliar a participação do setor privado, mas como a efetivação dos projetos esbarrava em problemas, acabava assumindo a responsabilidade por parte das ações.

Como exemplo, podemos citar uma ação estruturante de impacto direto no CentroOeste dentro do "Programa Brasil em Ação" que foi a inclusão da ferrovia Ferrovias Norte Brasil S.A. (Ferronorte) como investimento desse programa. A construção da ponte rodoferroviária sobre o Rio Paraná na divisa dos estados de Mato Grosso do Sul e São Paulo (SOUZA, 2011), representou uma importante realização para a estruturação do modal ferroviário, principalmente para os estados de Mato Grosso do Sul e Mato Grosso. Esses estados, por se posicionarem longe dos portos, demandam condições de movimentação de cargas a custos mais razoáveis, e o transporte ferroviário representa uma nova opção nesse sentido. 
Para o segundo mandato do governo de Fernando Henrique Cardoso foi gerado um novo programa que substituiu o Programa Brasil em Ação. As diretrizes estavam contidas no PPA (2000-2003).

Esse PPA deu origem ao programa denominado de "Avança Brasil” e foi criado pela Lei 9.989, de 21 de julho de 2000. A cobrança por avanços sociais, exigência contundente no decorrer do programa anterior, não desestrutura a continuidade dos eixos de desenvolvimento, pois segundo Castillo (2011, p. 350):

Herdeiros dos corredores de exportação dos anos 1970, os doze eixos do PPA 1996-1999 foram substituídos pelos nove eixos do PPA 2000-2003 sem que, com isso, fosse superada a ambiguidade entre redes e regiões, mas reforçando a mesma.

O autor ainda argumenta que ao priorizar a redução do "Custo Brasil" e buscar uma maior competitividade do país nos mercados internacionais de commodities, a proposta baseada nos ENIDs passa a substituir um planejamento estratégico, de base totalizadora, pela solução do problema de desenvolvimento por meio dos corredores de transportes.

Piva (1999, p. 2), crítico do governo Fernando Henrique Cardoso, ao discutir o PPA 2000-2003 em seus principais aspectos acredita que os eixos se voltam para ampliar e acelerar o transporte da produção nacional rumo aos portos para a exportação e que essa dinâmica agravaria as diferenças internas, porém estariam em consonância com “[...] o pensamento das nossas elites: elas não pensam o Brasil e sim algumas de suas camadas e regiões. O resto do país e da sociedade vira objeto de mera "política social".”. Mesmo considerando essa abordagem de cunho político-partidária, a questão enfatizada evidencia a proposta de extroversão já discutida por Castillo (2011).

A formulação das bases do programa Avança Brasil foi efetuada pelo Consórcio Brasiliana, que segundo Souza (2011) foi contratado pelo Banco Nacional de Desenvolvimento Econômico e Social (BNDES) e o Ministério do Orçamento e Gestão para elaborar os estudos com base nos Eixos Nacionais de Integração e Desenvolvimento. Nesses estudos seriam identificadas as possíveis oportunidades de investimentos públicos e privados os quais poderiam favorecer uma maior integração. A integração seria tanto de caráter nacional como internacional, além de um desenvolvimento econômico e social. Com isso 
seria possível reduzir as desigualdades regionais do Brasil. Ao final foram formulados nove eixos: Arco Norte, Madeira-Amazonas, Araguaia-Tocantins, Oeste, Transnordestino, Rótula, São Francisco, Sudoeste e Mercosul.

$\mathrm{Na}$ proposta a região Centro-Oeste era atravessada pelo eixo Araguaia-Tocantins, com influência em Goiás e no Leste de Mato Grosso; pelo eixo Oeste, impactando Mato Grosso e Mato Grosso do Sul; e Sudoeste, com rebatimentos em Mato Grosso do Sul. Os eixos de desenvolvimento vinculam-se diretamente aos corredores de exportação, tendo como lógica a busca por competitividade. Assim, as áreas mais afastadas dos portos deveriam ter uma condição de fluidez para permitir a circulação das mercadorias, leia-se commodities, de forma que a racionalidade exigida pela inserção internacional dos mercados fosse efetivada.

Como a proposta era a de parcerias entre o Estado e a iniciativa privada, inclusive com o controle operacional que esta última passava a obter a partir do processo de privatização que foi aprofundado no governo de Fernando Henrique Cardoso, as empresas passaram a ter um maior peso no planejamento territorial. Nesse contexto, a concepção de logística empresarial ganha importância frente às demandas exigidas no cenário de flexibilidade e competitividade do mercado internacional.

Para Becker (1993, p. 60), o setor privado encontra-se em melhores condições de operar a logística, pois a nova racionalidade - de feições globais e com base na tecnologia se difunde pela sociedade e pelo espaço, mas na sua operacionalidade, ou seja, na sua concretude, é seletiva, avançando mais rapidamente no setor produtivo privado. De outro lado, o setor público, em virtude da "[...] sua estrutura pesada e rígida, e os setores sociais desprovidos de meios econômicos e de informação, tem muito mais dificuldade em operar a logística.".

A maior agilidade do setor privado amplia suas ações no território na medida em que as condições de infraestrutura sejam adequadas ao processo de circulação necessária à reprodução do capital. A concepção dos ENIDs fortalece esse processo porque as ações territoriais, executadas pelo Estado, são direcionadas para proporcionar uma melhor operacionalidade do setor corporativo, favorecendo a sua fluidez. Com isso confirma-se a argumentação de Santos (2008a, p. 276) “A produção de fluidez é um empreendimento conjunto do poder público e do setor privado.". 
O fato dos eixos se encontrarem nas áreas de maior potencial produtivo e de serem extremamente extrovertidos implica numa manutenção das disparidades regionais, visto a falta de fomento nas áreas mais deprimidas.

Nesse sentido Souza (2011, p. 409) faz a seguinte consideração:

Grandes áreas do país, vistas como espaços não competitivos, momentaneamente, vão ficando marginalizadas nesse processo, tendo em vista que os governos - federal e locais - assim como o setor privado, concentram sua atuação nas áreas dinâmicas.

A lógica capitalista é coerente nesse sentido, já que para a reprodução ampliada do capital os espaços dinâmicos dispõem das melhores condições para a realização do ciclo produtivo, logo exercem atração dos investimentos privados por apresentarem uma produtividade espacial, pois:

Assim como se fala de produtividade de uma máquina, de uma plantação, de uma empresa, podemos, também, falar de produtividade espacial ou produtividade geográfica, noção que se aplica a um lugar, mas em função de uma determinada atividade ou conjunto de atividades. Essa categoria se refere mais ao espaço produtivo, isto é, a "trabalho" do espaço. (SANTOS, 2008a, p. 248).

A formulação de políticas públicas necessita ir além do atendimento das demandas corporativas, pois se por um lado a nova racionalidade corporativa exige as condições adequadas à sua efetivação - e o Estado prontamente esforça-se para atendê-las -, a demanda social por melhores condições se amplia. Assim, o Estado coloca-se como um gestor de crises, pois se os problemas de infraestruturas precárias atrasam o crescimento econômico do país, observa-se também uma melhora apenas tímida das demandas sociais, assim alguns problemas sociais já são considerados crônicos.

Esse cenário de comprometimento do Estado com a fluidez corporativa é intensificado no conjunto de novos programas, agora sob um novo governo, no âmbito dos PPAs seguintes. Daremos ênfase na sequência para o Programa de Aceleração do Crescimento (PAC) e para o Plano Nacional de Logística de Transportes (PNLT) cujos objetivos coadunam-se com a 
lógica anterior, agora com um novo rótulo em substituição aos corredores de exportação e aos eixos de desenvolvimento.

\subsubsection{O PAC e o Plano Nacional de Logística de Transportes (PNLT)}

A exigência legal da adoção dos planos plurianuais determinou um maior controle das ações impetradas pelo Estado, bem como passou a indicar as diretrizes das políticas públicas de cada governo. Findado o governo de Fernando Henrique Cardoso, o seu sucessor, Luiz Inácio Lula da Silva apresenta o seu PPA 2004-2007 com as indicações de prioridades e metas a serem alcançadas.

Segundo o Brasil (2008, p. 165-167), o PPA 2004-2007 organizou-se por megaobjetivos, tendo o Megaobjetivo II se concentrado na questão do "Crescimento com geração de emprego e renda, ambientalmente sustentável e redutor das desigualdades regionais", congregando três dimensões estratégicas e de longo prazo: dimensão econômica, dimensão regional e dimensão ambiental. Buscava-se superar os gargalos na infraestrutura, com ênfase para as áreas de energia elétrica, tanto na produção como na distribuição; expansão na produção de petróleo; expansão da infraestrutura de transportes com a manutenção das rodovias da malha federal, e investimentos no setor ferroviário, e nos acessos aos portos. Contudo, reconhece a necessidade de avanços nos investimentos específicos na área de infraestrutura, "[...] o que levou o Governo Federal a lançar o Programa de Aceleração do Crescimento (PAC) em janeiro de 2007, com o objetivo, dentre outros, de aumentar o investimento público em infra-estrutura.”.

Quando trata especificamente do setor de transportes, o relatório indica que pelo declínio observado dos investimentos em infraestrutura de transportes foi necessário criar o Projeto-Piloto de Investimentos (PPI) em 2005, cuja ênfase era a melhoria da trafegabilidade da malha federal para reduzir os gargalos no escoamento da produção agrícola.

O PPI serviu de base para a criação do PAC, lançado em janeiro de 2007. A criação de outro instrumento, o PNLT, desenvolvido em 2006 e concluído em 2007, serviu de base para os investimentos do PAC no setor de transportes. De acordo com o relatório de avaliação do Plano Plurianual 2004-2007: 
No setor rodoviário, por exemplo, a estratégia adotada foi a de conferir adequada trafegabilidade às principais rodovias federais, priorizando aquelas que são os principais corredores de exportação, bem como as principais ligações inter-regionais, descongestionando o tráfego de veículos pesados e leves de longa distância, que provocam retenção no trânsito e danificam o pavimento. (BRASIL, 2008, p. 211).

A menção aos corredores de exportação, conceito que será considerado superado a partir do PNLT, caracteriza a identificação dos investimentos de infraestrutura com os setores produtivos hegemônicos, apesar de uma tentativa de inclusão de outros extratos produtivos na pauta de exportações.

Como as exportações de commodities apresentam crescimento constante, a pressão sobre a infraestrutura de transportes nas áreas produtoras se eleva. $\mathrm{O}$ agravante é que a região Centro-Oeste, notadamente o estado de Mato Grosso, atinge uma escala produtiva que passa a pressionar todo o sistema logístico, ou seja, além do modal rodoviário, o mais utilizado, as conexões com o modal ferroviário e a destinação aos portos começam a gerar impactos diretos na fluidez, como no caso dos congestionamentos, implicando no aumento dos custos operacionais.

A urgência das intervenções e a necessidade de fomentar o crescimento da economia com substancial incremento do Produto Interno Bruto (PIB) levou à criação do PAC e do PNLT cujas ações implicaram em impactos territoriais sob um novo rótulo, mas com a sua essência herdada dos planos anteriores.

Discutindo a questão da regulação e do planejamento, Castillo (2011, p. 344-345) faz a seguinte consideração:

$\mathrm{Na}$ esfera federal, o "Plano Plurianual" (2008-2011), o "Programa de Aceleração do Crescimento" (2007-2010) e o "Plano Nacional de Logística e Transportes" (2008-2023) podem revelar, em suas intenções e na lista de investimentos em infraestruturas, o comprometimento do Estado com a fluidez do território para algumas categorias de produtos e de agentes. 
As discussões que se seguem partem da análise dos elementos constituintes dos planos e programas elencados com ênfase para as repercussões territoriais em Mato Grosso. Como as ações possuem um caráter de integração, já que a infraestrutura de transporte compreende na sua conformação a concepção de redes (rodoviária, ferroviária, hidroviária e portuária), procuraremos vislumbrar as conexões mais diretas no estado, apesar do entendimento de totalidade do conjunto.

O PPA 2008-2011 propõe a organização das ações do governo com base em três eixos: crescimento econômico, agenda social e educação de qualidade. Na mensagem presidencial ao Congresso Nacional fica explícita a confiança nas ações programadas no PAC para manter o ritmo de crescimento, Para tal, propõe a remoção dos obstáculos normativos e administrativos, o estímulo aos investimentos privados e o aumento dos investimentos públicos em infraestrutura.

De acordo com Brasil (2007a, p. 19):

A elevação do nível de investimento pelo setor público na resolução dos gargalos existentes na infra-estrutura logística e energética, aliada à continuidade das políticas inclusivas - essenciais à expansão do mercado interno -, é fundamental para a expansão da capacidade produtiva nacional e da elevação da produtividade sistêmica da economia.

A menção à infraestrutura logística é fruto da nova orientação que considera o sistema como um todo, presente inclusive ao citar a condição sistêmica da economia, somada com o signo da produtividade, cuja busca é objetivo presente no cenário competitivo do mercado globalizado. A proposta visa à diversificação de modais, pois a interiorização do desenvolvimento no país exige nova postura na medida em que as demandas sobre a infraestrutura se desloca para áreas pouco diversificadas quanto à composição dos modais de transportes.

Para Castillo (2011, p. 346-347), a superação dos gargalos logísticos, o aumento da competitividade e a redução das desigualdades regionais são as principais metas do PAC em relação à logística. $\mathrm{O}$ alcance das metas depende das ações especificas em rodovias e ferrovias (construção, manutenção e duplicação), investimentos nos portos e aeroportos e na construção 
de gasodutos, em suma, grande parte dos investimentos em logística do programa "[...] se relacionam ao escoamento de produtos agrícolas provenientes do Cerrado.”.

Para compreendermos mais detalhadamente as ações do PAC voltados para a logística é necessário analisar o PNLT, visto que esse plano objetiva retomar o planejamento para o setor tanto no médio prazo como no longo prazo.

Conforme aponta Rocha Neto (2013, p. 292-293), o surgimento do PNLT ocorre num momento em que o setor de transportes é concebido como interinstitucional, portanto exigente de uma integração maior no seu tratamento. Contudo, o Ministério dos Transportes e o Ministério da Defesa foram os responsáveis pela formulação final do Plano que irá subsidiar os PPAs até o ano de 2023, sendo que "[...] essa visão de planejamento para os transportes confere ao PNLT status de Plano de Estado, conforme defende o Ministério dos Transportes $[\ldots] "$.

No conjunto das "ideias-força" que orientam o PNLT, é importante destacar alguns elementos nodais do plano: a) o Plano é nacional e federativo e não apenas federal; b) por ser multimodal envolve toda a cadeia logística associada aos transportes; c) demanda um planejamento permanente com ampla participação da sociedade, já que é integrado e de caráter interinstitucional; d) compromete-se com a questão ambiental (Zoneamento Ecológico-Econômico); e) demanda reorganização administrativa para uma gestão eficiente e eficaz; f) "Está fortemente fundamentado nos conceitos de territorialidade, de segurança e ocupação do território nacional, e de desenvolvimento sustentável do País, com equidade e justiça social.” (BRASIL, 2007b, p. 5-6). (Grifo nosso).

Ao lado das ideias de desenvolvimento sustentável - imperativo do mundo moderno e sua relação conflituosa com a natureza -, e das questões sociais prementes em qualquer proposta política, ascende a questão territorial como nos discursos geopolíticos que embasavam os planos nacionais de desenvolvimento do período militar.

Sobre a questão territorial, cabe aqui a discussão da relação territorial e logística. De acordo com Silveira (2011a, p. 60-61), existem duas logísticas, a logística organizacional e a logística territorial, que se relacionam, pois são interdependentes. A primeira está voltada para o aumento da circulação de capital das empresas, já a segunda direciona-se ao planejamento referente às demandas de infraestrutura e na criação das normas, convergindo para a eficiência da fluidez territorial levando por consequência à alteração do território representado 
pelos espaços urbanos e rurais. O autor finaliza com o seguinte argumento: "Na "logística territorial" estão contidos os sistemas de normas e de técnicas e seu principal agente configurador é o Estado.”.

Pensar o território em longo prazo torna-se essencial, pois a demanda reprimida em vários setores, como o de transportes, demonstra como custa caro à sociedade as políticas imediatistas como as que ocorreram nos períodos anteriores, principalmente durante as crises.

A infraestrutura é um desses setores primordiais e exigentes de investimentos constantes. Assim, considerando que as obras de infraestrutura demandam normalmente prazos mais longos para a sua execução e necessita de manutenção sistemática, é importante o posicionamento do PNLT ao apontar para um plano de Estado e não de Governo, pois assegura continuidade das ações estratégicas desde que coerentes com as necessidades sociais e sob a vigilância dos órgãos de controle.

Como assinala Castillo (2011, p. 347), o planejamento setorial é retomado pelo PNLT, o qual passa a oferecer “[...] subsídios à formulação dos PPAs 2008-2011, 2012-2015, 20162019 e 2020-2023, no que compete à racionalidade e à qualificação dos gastos públicos em logística.".

O Brasil (2007b) traz no Relatório Executivo do PNLT para o ano de 2007, o conjunto do plano que procura atender aos seguintes objetivos:

- Primeiro: considerado fundamental, é a retomada do planejamento voltado ao setor de transportes com a implantação de uma estrutura permanente e com base em dados técnicos (informações georreferenciadas) disponibilizados para esse fim;

- Segundo: considerar os custos da cadeia logística como um todo, desde a origem até o destino do fluxo;

- Terceiro: trata do equilíbrio da matriz de transportes do país, hoje fundamentada principalmente no modal rodoviário;

- Quarto: relacionado à questão ambiental, como na questão de áreas com restrições; 
- Quinto: voltado à gestão, busca o enquadramento dos projetos estruturantes por categorias, quais sejam: Aumento da eficiência produtiva em áreas consolidadas (AEP), Indução ao desenvolvimento de áreas de expansão de fronteira agrícola e mineral (IDF), Redução de desigualdades regionais em áreas deprimidas (RDR) e integração regional sul-americana (IRS).

Quanto à questão da integração regional sul-americana, Rocha Neto (2013, p. 299) chama a atenção para a lógica territorial inerente ao PNLT, ao considerar para esse plano a função de "amalgamar o espaço sul-americano, sobretudo em relação aos países meridionais, revelando uma abordagem territorial em escala continental.”. Mas o autor pontua, com base na obra de Vera (2011), que a integração parece se restringir às conexões entre as malhas viárias de cada país, o que torna possível o acesso aos mercados e aos pontos de apoio logístico. Em suma, a integração resume-se em investimentos em infraestrutura e em propostas de marcos normativos que atendam aos fluxos gerados.

A proposta de investimentos indicados no PNLT subsidia-se por uma nova metodologia de agrupamento que deu origem a uma nova representação da organização espacial. Essa representação tem a logística como base dos fatores de agregação e geraram os vetores logísticos. No PNLT constam sete vetores: Amazônico, Centro-Norte, Nordeste Setentrional, Nordeste Meridional, Leste, Centro-Sudeste e Sul (BRASIL, 2007b, p. 12).

A Figura 2, extraída do relatório executivo do PNLT, expressa espacialmente os sete vetores elencados anteriormente. 
Figura 2 - Vetores logísticos da organização espacial brasileira

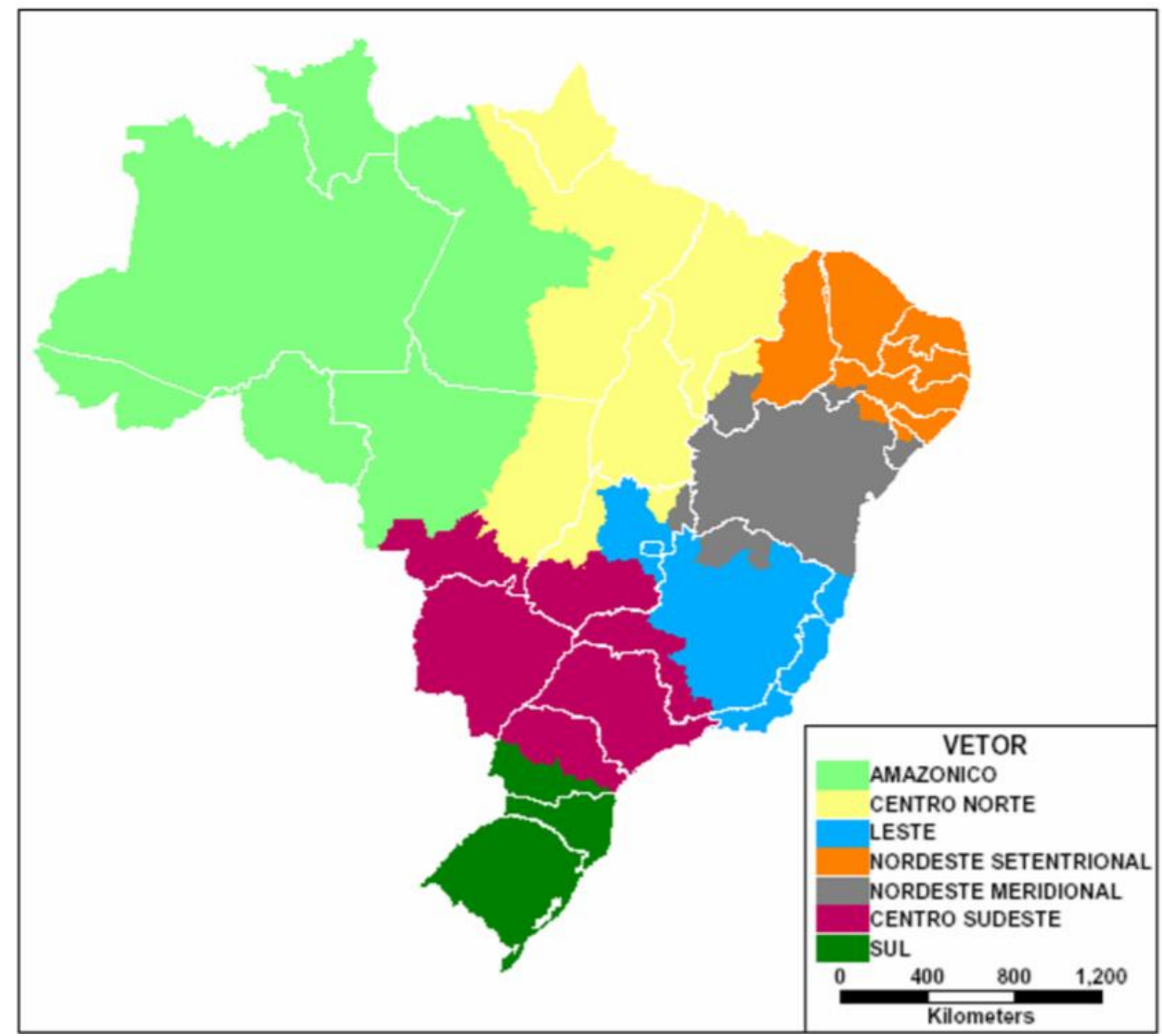

Fonte: PNLT, Relatório Executivo, 2007

A região Centro-Oeste divide-se em cinco vetores, não tendo contiguidade direta apenas com os vetores Nordeste Setentrional e Sul, portanto possui posição estratégica ao fazer contato com grande parte do país.

A proposta de corredores de exportação considerada superada no discurso do PNLT, conforme aponta Castillo (2011), é revelada na composição da metodologia de agrupamento das microrregiões desse plano. Assim, fica explícito ao observar no texto de Brasil (2007b, p. 12) quando esse trata da espacialização territorial por vetores logísticos e coloca como um dos fatores representativos para o agrupamento das microrregiões homogêneas as "Perspectivas de integração e inter-relacionamento (a antiga noção de "corredores de transporte")". 
A concepção nova, proposta por meio dos vetores, se aproxima dos corredores de exportação na medida em que as ações pretéritas do Estado surtiram efeitos na reestruturação do território ao produzir áreas homogêneas de produção, como é o caso das vastas áreas do Centro-Oeste com as commodities. Assim, mesmo com o discurso de redução dos desequilíbrios regionais, fica claro que o relatório aponta as áreas com melhores perspectivas para os investimentos, tanto públicos como privados, fornecendo informações importantes para a ação sobre o território dos diversos agentes. Essas ações convergem para as áreas mais dinâmicas ou para aquelas cujo potencial é considerado promissor.

Para Silveira (2013, p. 44), são os fluxos de exportações e importações que se dão nos corredores de exportação os promotores do aumento da movimentação de cargas nas rodovias e nos portos. Esses corredores, porém, ao serem selecionados pelas corporações pelo potencial apresentado nos diversos estudos, não conseguem atender a função demandada, como é o caso das áreas de expansão da frente pioneira do Centro-Oeste, do interior do Nordeste e da Região Norte. Para o autor, esse cenário demonstra que: "O Brasil, em grande parte, ficou dependente dos "corredores de exportação", onde a maioria dos recursos estatais em infraestruturas de transportes e investimentos privados é empregada." (SILVEIRA, op. cit., p. 44).

O discurso de equidade fica esvaziado, pois para atender os interesses corporativos o Estado termina por investir em áreas que já possuem certo dinamismo, ou perspectivas para tal. Segundo Blanco e Rodrigues (2011, p. 6) é condição recorrente na estruturação de redes de circulação confiar em nós existentes e ainda estimular a constituição de novos nós, principalmente em pontos em que haja conexões com outros corredores ou ao longo de um mesmo corredor. Dessa forma, as parcerias entre o poder público e a iniciativa privada, expresso na modalidade de Parceria Público-Privada (PPP) sofre pressão para inverter recursos para o conjunto das melhores oportunidades, que normalmente convergem para as áreas mais articuladas.

Os investimentos voltados para o Centro-Oeste, por exemplo, estão concentrados nas áreas vinculadas ao agronegócio, ficando grandes porções da região com as condições de infraestruturas aquém das necessidades, tornando-as pouco atrativas para receber certos investimentos.

Nos Quadros 3, 4 e 5 podemos observar os projetos do portfolio prioritário para a região Centro-Oeste que foram distribuídos por tipo de modal. Esses projetos são 
recomendados como prioridade de investimentos por possuírem uma taxa interna de retorno econômico (TIRE) de no mínimo de 8 a $12 \%$.

Quadro 3 - Projetos do modal rodoviário para a região Centro-Oeste

\begin{tabular}{|c|c|c|c|c|c|c|c|}
\hline Vetor & Modo & Nome & $\begin{array}{c}\text { Tipo de } \\
\text { Intervenção }\end{array}$ & $\begin{array}{l}\text { Investimento } \\
\text { Total (R\$ mil) }\end{array}$ & Extensão & TIRE & Implantação \\
\hline $\begin{array}{l}\text { Amazônico/ } \\
\text { Centro Norte }\end{array}$ & Rodoviário & $\begin{array}{l}\text { MT-322 (BR- } \\
\text { 080): Bom } \\
\text { Jesus do } \\
\text { Araguaia-MT a } \\
\text { Peixoto de } \\
\text { Azevedo-MT }\end{array}$ & Pavimentação & 736.393 & 408 & $\begin{array}{c}12 \\
a \\
16 \%\end{array}$ & Até 2015 \\
\hline $\begin{array}{l}\text { Centro } \\
\text { Sudeste / } \\
\text { Leste }\end{array}$ & Rodoviário & $\begin{array}{l}\text { BR-050: } \\
\text { Cristalina-GO a } \\
\text { Cumari-GO }\end{array}$ & Terceira faixa & 350.474 & 219 & $\begin{array}{l}12 \mathrm{a} \\
16 \%\end{array}$ & Até 2015 \\
\hline $\begin{array}{l}\text { Nordeste } \\
\text { Meridional / } \\
\text { Leste }\end{array}$ & Rodoviário & $\begin{array}{l}\text { BR-020: } \\
\text { Formosa-GO a } \\
\text { Guarani de } \\
\text { Goiás-GO }\end{array}$ & Terceira faixa & 399.075 & 249 & $\begin{array}{l}\text { Acima } \\
\text { de } \\
24 \%\end{array}$ & Até 2015 \\
\hline Centro Norte & Rodoviário & $\begin{array}{l}\text { BR-070 } \\
\text { Aragarças-GO }\end{array}$ & Pavimentação & 85.870 & 48 & $\begin{array}{c}8 \mathrm{a} \\
12 \%\end{array}$ & Até 2015 \\
\hline $\begin{array}{l}\text { Centro } \\
\text { Sudeste }\end{array}$ & Rodoviário & $\begin{array}{l}\text { BR-364: Jataí- } \\
\text { GO a São } \\
\text { Simão-GO }\end{array}$ & Terceira faixa & 244.610 & 153 & $\begin{array}{l}16 a \\
24 \%\end{array}$ & Até 2015 \\
\hline $\begin{array}{l}\text { Centro } \\
\text { Sudeste }\end{array}$ & Rodoviário & $\begin{array}{l}\text { GO-020: } \\
\text { Goiânia-GO a } \\
\text { Bela Vista de } \\
\text { Goiás-GO }\end{array}$ & Terceira faixa & 72.661 & 45 & $\begin{array}{l}8 \mathrm{a} \\
12 \%\end{array}$ & Até 2015 \\
\hline $\begin{array}{l}\text { Centro } \\
\text { Sudeste }\end{array}$ & Rodoviário & $\begin{array}{l}\text { BR-364: Santa } \\
\text { Rita do } \\
\text { Araguaia-GO a } \\
\text { Jataí-GO }\end{array}$ & Terceira faixa & 308.289 & 192 & $\begin{array}{l}\text { Acima } \\
\text { de } \\
24 \%\end{array}$ & Até 2015 \\
\hline $\begin{array}{l}\text { Centro } \\
\text { Sudeste }\end{array}$ & Rodoviário & $\begin{array}{l}\text { BR-452: Rio } \\
\text { Verde-GO a } \\
\text { Itumbiara-GO }\end{array}$ & Terceira faixa & 301.392 & 188 & $\begin{array}{l}\text { Acima } \\
\text { de } \\
24 \%\end{array}$ & Até 2015 \\
\hline $\begin{array}{l}\text { Centro } \\
\text { Sudeste }\end{array}$ & Rodoviário & $\begin{array}{l}\text { BR-163: Anel } \\
\text { rodoviário de } \\
\text { Campo Grande- } \\
\text { MS }\end{array}$ & Duplicação & 142.525 & 29 & $\begin{array}{c}8 \mathrm{a} \\
12 \%\end{array}$ & Até 2015 \\
\hline $\begin{array}{l}\text { Centro } \\
\text { Sudeste }\end{array}$ & Rodoviário & $\begin{array}{l}\text { MS-040: } \\
\text { Brasilândia a } \\
\text { Campo Grande- } \\
\text { MS }\end{array}$ & $\begin{array}{l}\text { Construção e } \\
\text { pavimentação }\end{array}$ & 920.920 & 322 & $\begin{array}{c}8 \mathrm{a} \\
12 \%\end{array}$ & $\begin{array}{l}2016 \\
a \\
2019\end{array}$ \\
\hline $\begin{array}{l}\text { Centro } \\
\text { Sudeste }\end{array}$ & Rodoviário & $\begin{array}{l}\text { BR-163: Campo } \\
\text { Grande-MS a } \\
\text { Nova Alvorada } \\
\text { do Sul-MS }\end{array}$ & Duplicação & 498.838 & 102 & $\begin{array}{l}\text { Acima } \\
\text { de } \\
24 \%\end{array}$ & Até 2015 \\
\hline $\begin{array}{l}\text { Centro } \\
\text { Sudeste }\end{array}$ & Rodoviário & $\begin{array}{l}\text { BR-163: Campo } \\
\text { Grande-MS a } \\
\text { Sonora-MS }\end{array}$ & Duplicação & 1.709 .814 & 350 & $\begin{array}{c}8 \mathrm{a} \\
12 \%\end{array}$ & $\begin{array}{c}2020 \\
a \\
2023 \\
\end{array}$ \\
\hline Leste & Rodoviário & $\begin{array}{l}\text { BR-070: } \\
\text { Cocalzinho de } \\
\text { Goiás-GO }\end{array}$ & Terceira faixa & 78.596 & 49 & $\begin{array}{c}8 \mathrm{a} \\
12 \%\end{array}$ & Até 2015 \\
\hline Leste & Rodoviário & $\begin{array}{l}\text { BR-040: } \\
\text { Lusiânia-GO a } \\
\text { Cristalina-GO }\end{array}$ & Terceira faixa & 114.846 & 72 & $\begin{array}{l}16 a \\
24 \%\end{array}$ & Até 2015 \\
\hline
\end{tabular}

Fonte: PNLT, Relatório final (2012) 
Quadro 4 - Projetos do modal hidroviário para a região Centro-Oeste

\begin{tabular}{|c|c|l|c|c|c|c|c|}
\hline Vetor & Modo & Nome & $\begin{array}{c}\text { Tipo de } \\
\text { Intervenção }\end{array}$ & $\begin{array}{c}\text { Investimento } \\
\text { Total (R\$ mil) }\end{array}$ & Extensão & TIRE & Implantação \\
\hline Amazônico & Hidroviário & $\begin{array}{l}\text { Hidrovia Teles } \\
\text { Pires - Juruena - } \\
\text { Tapajós }\end{array}$ & $\begin{array}{c}\text { Implantação } \\
\text { de } \\
\text { Hidrovias }\end{array}$ & 1.428 .750 & 1.600 & $\begin{array}{c}\text { Acima } \\
\text { de } \\
24 \%\end{array}$ & Até 2015 \\
\hline Centro Norte & Hidroviário & $\begin{array}{l}\text { Hidrovia do } \\
\text { Araguaia- } \\
\text { Tocantins: } \\
\text { Pontal do } \\
\text { Araguaia-MT a } \\
\text { Aragarças-GO }\end{array}$ & $\begin{array}{l}\text { Implantação } \\
\text { de } \\
\text { Hidrovias }\end{array}$ & 1.490 .467 & 1.500 & $\begin{array}{c}16 \\
\text { a } \\
24 \%\end{array}$ & Até 2015 \\
\hline
\end{tabular}

Fonte: PNLT, Relatório final (2012)

\section{Quadro 5 - Projetos do modal ferroviário para a região Centro-Oeste}

\begin{tabular}{|c|c|c|c|c|c|c|c|}
\hline Vetor & Modo & Nome & $\begin{array}{c}\text { Tipo de } \\
\text { Intervenção }\end{array}$ & $\begin{array}{l}\text { Investimento } \\
\text { Total (R\$ mil) }\end{array}$ & Extensão & TIRE & Implantação \\
\hline $\begin{array}{l}\text { Centro } \\
\text { Sudeste }\end{array}$ & Ferroviário & $\begin{array}{l}\text { Ferronorte: } \\
\text { Uberlândia-MG } \\
\text { a Alto Araguaia- } \\
\text { MT }\end{array}$ & $\begin{array}{l}\text { Recuperação e } \\
\text { remodelagem }\end{array}$ & 1.890 .000 & 700 & $\begin{array}{c}8 \\
a \\
12 \%\end{array}$ & Até 2015 \\
\hline $\begin{array}{l}\text { Centro } \\
\text { Sudeste }\end{array}$ & Ferroviário & $\begin{array}{l}\text { Ligação } \\
\text { ferroviária: } \\
\text { Corumbá-MS a } \\
\text { Santos-SP }\end{array}$ & $\begin{array}{l}\text { Recuperação e } \\
\text { remodelagem }\end{array}$ & 3.442 .500 & 1.275 & $\begin{array}{c}8 \\
a \\
12 \%\end{array}$ & Até 2015 \\
\hline Leste & Ferroviário & $\begin{array}{l}\text { Ligação EF-354: } \\
\text { Campinorte/GO } \\
\text { - Macaé/RJ }\end{array}$ & $\begin{array}{l}\text { Construção de } \\
\text { ferrovias }\end{array}$ & 7.348 .500 & 1.633 & $\begin{array}{c}8 \\
a \\
12 \% \\
\end{array}$ & $\begin{array}{c}2016 \\
a \\
2019 \\
\end{array}$ \\
\hline
\end{tabular}

Fonte: PNLT, Relatório final (2012)

É importante frisar que um dos aspectos norteadores da seleção dos projetos prioritários é o seu potencial econômico. Assim, as Taxas Internas de Retorno Econômico (TIRE) devem oferecer uma margem que justifique os investimentos. O mínimo esperado para uma área prioritária é de $8 \%$, mas é possível notar que o índice aumenta na medida em que convergem para as áreas mais dinâmicas, notadamente grandes áreas produtoras e corredores de exportação.

Dessa forma, é possível relacionar os investimentos previstos com as rotas de escoamento da produção agrícola, como no caso das hidrovias projetadas, pois essas estão diretamente vinculadas às áreas consolidadas e de expansão do agronegócio, como pode ser observado no Mapa 2.

Essas áreas prescindem de agilidade e de redução de custos da movimentação de commodities para as áreas portuárias, para isso invertem o sentido do fluxo, pois objetivam os portos da região Norte do país que já estão sendo estruturados para receber parte significativa da produção de grãos. 
Mapa 2 - Hidrovias prioritárias para a região Centro-Oeste

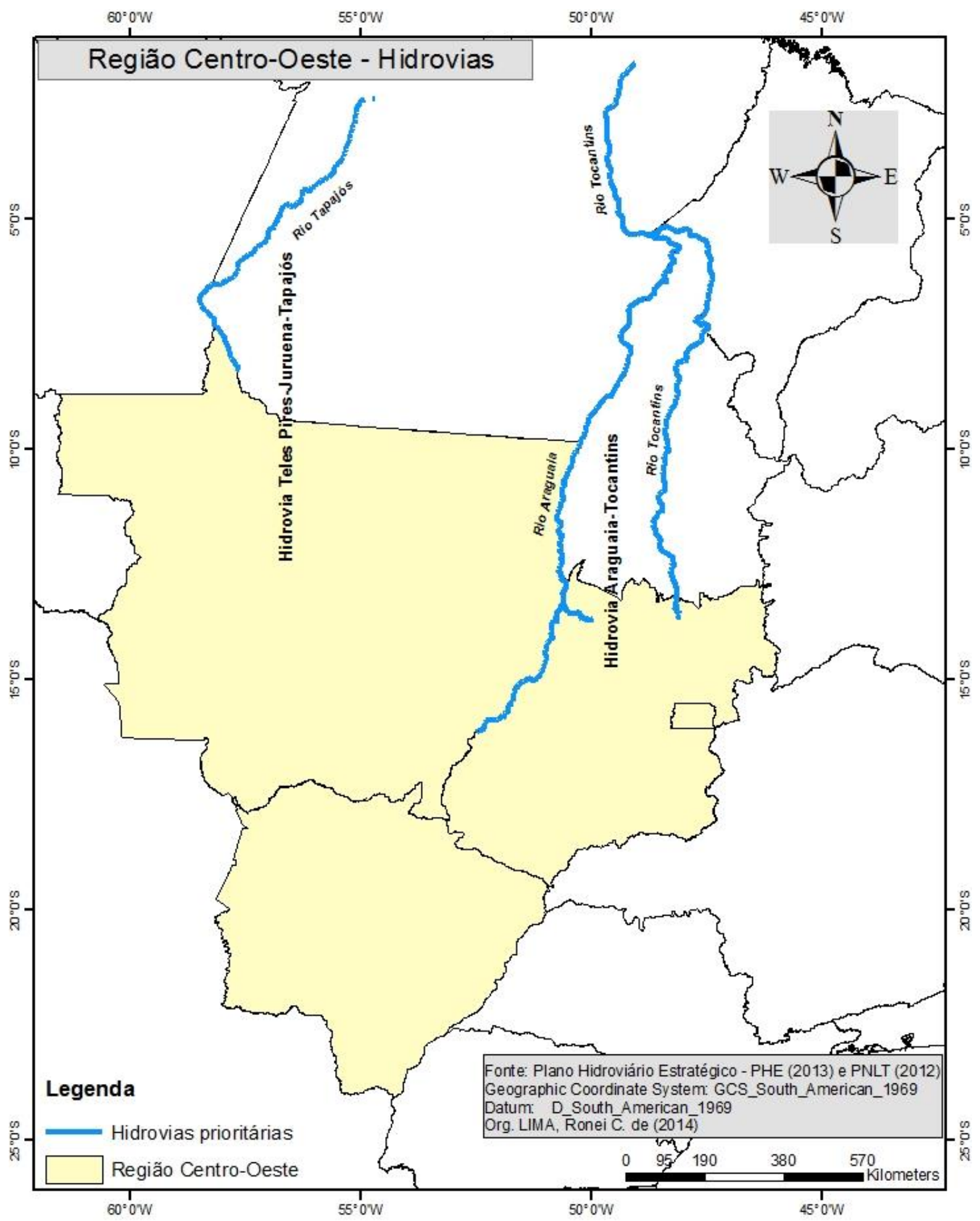

Fonte: PNLT, (2012) e Plano Hidroviário Estratégico - PHE (2013)

Já as ferrovias identificadas nos projetos prioritários mantém a relação com as áreas economicamente consolidadas, representadas pelos vetores Leste e Centro Sudeste. A de maior custo, a ligação do trecho entre Campinorte (GO) a Macaé (RJ), faz parte de um projeto 
maior e ambicioso, denominado de Ferrovia Transcontinental (EF-354), cuja pretensão é chegar até a divisa com o Peru. Ao contrário dos demais investimentos no setor ferroviário os quais objetivam recuperação e remodelagem de ferrovias já existentes, a EF-354 ainda será construída, tendo um horizonte aproximado de término das obras para 2019.

Quanto ao modal rodoviário, a quase totalidade dos investimentos se volta para a readequação das rodovias à intensidade dos fluxos, pois a demanda é reprimida pelas condições das rodovias. Esse quadro deriva dos investimentos efetivados com base na realidade pretérita e que não foram atualizados, ou seja, deixaram de acompanhar a elevação massiva da movimentação de cargas.

Como as previsões dos estudos do PNLT é para a elevação de uso das vias, as taxas de TIRE em alguns trechos estão acima de $24 \%$, como é o caso das ligações entre: Formosa-GO a Guarani de Goiás-GO, na BR-020; Santa Rita do Araguaia-GO a Jataí-GO, na BR-364; Rio Verde-GO a Itumbiara-GO, na BR-452; Campo Grande-MS a Nova Alvorada do Sul-MS, na BR-163. É importante salientar que essas áreas possuem relação direta com o agronegócio, pois drenam a produção de importantes regiões produtoras de grãos e carnes.

Fica revelado com as prioridades elencadas que o planejamento estatal está em consonância com os interesses do agronegócio, assim caracterizando ações para um uso corporativo desse setor econômico, pois as bases de investimentos previstos têm como elemento nodal o retorno dos investimentos auferidos. Esses investimentos derivam de três frentes: da iniciativa privada, do poder público e das parcerias público-privadas que são cada vez mais frequentes.

Considerando um cenário amplo, é possível afirmar que a efetivação dos projetos públicos exige a sincronia de uma série de fatores:

1) condições macroeconômicas equilibradas, já que a estabilidade das contas públicas é fator preponderante para o financiamento dos projetos;

2) conjunturas internacionais favoráveis, dado o grau de integração nacional com o mercado internacional;

3) sistemas de normas em consonância com as metas estipuladas (como aquelas que tornam mais ágeis as ações burocráticas e de controle); 
4) apoio da sociedade, necessário para legitimar o encaminhamento político das ações planejadas;

5) ganho social por parte do maior conjunto possível da sociedade, daí a necessidade de investimentos nas áreas sociais para contrabalançar as inversões voltadas ao setor produtivo.

Nesse contexto, as projeções do PNLT indicam um aumento considerável por consumo, por investimentos e pela necessidade premente de fluidez, haja vista a complexificação das relações estabelecidas, cada vez mais desejosas de movimento.

A tão propalada integração, seja interna ou externa, prescinde de um processo de reestruturação territorial para atender as novas exigências. Exigências essas que dependem diretamente das condições dos sistemas de transportes e armazenamento bem como da logística inerente a esses sistemas.

Iniciamos esse capítulo afirmando que o Estado assume o papel central para criar as condições territoriais adequadas para a entrada do agente privado no novo processo produtivo pautado na racionalidade capitalista. E, por mais que as ações do Estado se destinem ao controle do território pela proposta de integração e ocupação - evidenciada pelas políticas de ocupação efetivadas principalmente a partir de 1970 -, fica evidente a estreita relação entre os agentes hegemônicos, quais sejam o Estado e os grupos capitalistas, cuja parceria resulta no condicionamento do território às demandas corporativas.

O discurso atual, assim como os seus antecessores, busca a sua legitimação com o apelo social das obras que geram empregos e riqueza durante a suas execuções e depois de serem concluídas. De fato, as infraestruturas criadas servem à sociedade como um todo. No entanto, com a reduzida capacidade de financiamento de tais investimentos, principalmente do Estado, são criadas as estratégias de direcionamento de recursos, como os projetos prioritários, os corredores de exportação, os eixos de desenvolvimento e os vetores logísticos. Esses, porém, não conseguem abarcar a totalidade territorial.

O estado de Mato Grosso, pelas suas dimensões e características construídas historicamente, tem no seu território as marcas das políticas públicas cujos rebatimentos criaram um quadro de profundas desigualdades internas que necessitam ser superadas. No entanto, as perspectivas apontadas no horizonte próximo são de investimentos pontuais, principalmente em infraestruturas voltadas aos transportes em áreas dinâmicas ou com 
potencial de crescimento promissor. Para as demais restam os rebatimentos secundários e a permanência no estado de precariedade que já se encontram.

Portanto, no capítulo seguinte nos aproximamos mais do nosso objeto de estudo, quando trataremos da condição atual da fluidez territorial do estado de Mato Grosso, da sua dinâmica de integração interna e externa, da condição do agronegócio como elemento de convergência das ações públicas e privadas e finalmente das áreas que se encontram preteridas por não estarem em consonância com os projetos de reestruturação destinados a essa porção do território brasileiro. 


\section{LOGÍSTICA E INDÚSTRIA: O USO CORPORATIVO DO TERRITÓRIO EM MATO GROSSO}

Considerando a questão das escalas de análise da logística do agronegócio em Mato Grosso, discutimos inicialmente a dinâmica dos movimentos de fundo, ou seja, daqueles que incidem de forma direta ou indireta na produção do espaço. Nesse caso, argumentamos que as alterações ocorridas no regime de acumulação e de regulação dentro do sistema capitalista de produção implicaram em desdobramentos espaciais diferenciados em uma escala macro, ou seja, no nível mundial.

Assim, a territorialização dos fenômenos advindos dessa dinâmica concorre para a criação de uma nova divisão territorial do trabalho. Internamente, no nível nacional, a elevação da inserção brasileira na economia capitalista favorece a constituição de uma nova divisão inter-regional do trabalho, pois se buscava uma integração maior junto aos mercados nacional e internacional, com a criação de especializações produtivas nas diversas áreas do país.

A integração proposta sob a égide de uma racionalidade capitalista conduziu a um quadro em que parte das regiões menos integradas passa a responder por uma nova função. A modernização conservadora da agricultura foi um desdobramento das novas intencionalidades dos agentes hegemônicos.

O Estado é chamado para alavancar o funcionamento do novo modelo produtivo modernizado que viria a reorganizar as áreas em consonância com a nova lógica. $\mathrm{O}$ estado de Mato Grosso foi incluído nesse processo por possuir condições favoráveis para a implantação do modelo por conta das condições naturais satisfatórias e principalmente pelas condições sociais, devido ao estoque de terras com facilidade de ocupação. Desse quadro, surge a possibilidade desse agente agir de acordo com seus projetos geopolíticos de maior controle territorial e principalmente, de fornecer as condições de avanço do capitalismo no interior do país.

O Estado, como vimos, cria as condições de infraestrutura e de financiamento que resulta na criação e consolidação do projeto capitalista sob a forma da agropecuária empresarial que origina o conjunto do agronegócio. Com isso temos a base para a 
corporatização do território mato-grossense, assim como ocorreu no restante da região Centro-Oeste e da região Norte. No caso de Mato Grosso, a constituição de um novo modelo produtivo implicou na formação de novos fenômenos.

Diante do exposto, discutiremos nesse capítulo os circuitos espaciais produtivos e os círculos de cooperação que no seu conjunto respondem pela racionalidade capitalista global, e por isso implica em fluxos de diversas naturezas. Aqui se encontra o nó entre a produção e a circulação, elemento importante desse trabalho; a logística de transportes já existente, representada pelo modal rodoviário, que é a base para a movimentação de cargas; o novo elemento logístico de Mato Grosso, a ferrovia ALLMN, cuja territorialização no Sul do estado confere a essa área uma posição privilegiada na atual estrutura logística; a relação entre a logística existente com a concentração agroindustrial no estado, tendo em vista a confluência de interesses do setor privado em ter acesso a melhores condições infraestruturais e do Estado em dinamizar economicamente regiões específicas (dotação de infraestruturas, isenções e renúncias fiscais); e finalmente a questão dos gargalos logísticos, principal entrave para uma maior hegemonia do setor corporativo ligado ao agronegócio.

\subsection{OS CIRCUITOS ESPACIAIS DA PRODUÇÃo E OS CÍRCULOS DE COOPERAÇÃO}

A busca por uma compreensão mais profunda do funcionamento do território, como aponta Santos e Silveira (2004, p. 143), exige a captação do seu movimento. Nesse sentido é imprescindível discutir a questão territorial considerando a formação dos circuitos espaciais da produção, que são definidos “[...] pela circulação de bens e produtos e, por isso, oferecem uma visão dinâmica, apontando a maneira como os fluxos perpassam o território.”.

A articulação dos diversos subespaços, como atesta Santos (2012, p. 55-56), se dá sob uma lógica global, logo não é mais possível falar de circuitos regionais de produção, pois com a elevação da especialização regional e a diversidade de fluxos de diversos níveis de intensidade, tipo e direção, necessitamos “" [...] falar de circuitos espaciais da produção. Esses seriam as diversas etapas pelas quais passaria um produto, desde o começo do processo de produção até chegar ao consumo final.”. 
Com a tecnificação da base produtiva, como é o caso da agricultura moderna, a alta dependência de insumos - tanto a montante como a jusante do processo produtivo - eleva o grau de articulação existente entre o lugar da produção e todos os setores que são necessários para a sua efetivação, bem como nas demais fases de circulação e de consumo. Assim, comungamos com a assertiva de Bernardes (2015, p. 17) quando propõe que:

A criação das redes de produção agropecuárias globalizadas, associadas à fluidez promovida pela implantação dos novos sistemas de engenharia dos transportes e comunicações, permite que os circuitos espaciais de produção e os círculos de cooperação alcancem áreas mais distantes, proporcionando movimentos de reorganização do campo e da cidade, de sistemas urbanos mais complexos e de inter-relações cada vez mais intensas entre as cidades.

Se a lógica é global, a produção de um local não necessariamente deverá ser consumida nesse mesmo local, pois a constituição da produção implica em que essa seja produzida numa escala que possibilite movimentar-se do ponto de produção ao ponto de consumo independente das distâncias percorridas. Sobre a condição das distâncias espaciais na relação produção-consumo, Carlos (1994, p. 110) faz a seguinte consideração:

Como produção e consumo estão cada vez mais distanciados espacialmente (condição histórica do desenvolvimento do capitalismo), o processo de produção deve criar as condições de ligação entre essas esferas da produção geral, de modo a minimizar o tempo de duração no qual o produto se transfere de um momento a outro. Uma série de atividades particulares, encadeadas, são criadas com esse objetivo.

Essa lógica está presente no território mato-grossense com a produção de commodities, visto a constituição dessas enquanto mercadoria internacional, implicando na sua padronização em diversos níveis, como preço e padrão de qualidade, bem como com a demanda por fluxos constantes e regulares para o mercado externo, que prescinde de agilidade nos transportes para a redução do tempo total de circulação. Por conseguinte, a complexificação do processo produtivo, cujo conjunto encontra-se disperso por diversos subespaços, exige um sistema de controle igualmente eficaz e eficiente para realizar as ações de acordo com os objetivos pensados para o processo como um todo (produção geral). 
Para Santos e Silveira (2004), com o passar do tempo, os diversos lugares em sua individualidade se tornam alvos de sucessivas divisões do trabalho com vinculo direto com os fluxos, logo implicando na superposição dos circuitos da produção nesses lugares. Surgem, nesse processo, as solidariedades entre os elementos novos e os elementos já existentes.

No conjunto, temos a conformação de diferentes combinações técnicas e sociais do trabalho num dado momento histórico. Assim,

No período atual, esse movimento é comandado sobretudo por fluxos não obrigatoriamente materiais, isto é, capitais, informações, mensagens, ordens. Essa é a inteligência do capital, reunindo o que o processo direto da produção havia separado em diversas empresas e lugares, mediante o aparecimento de verdadeiros círculos de cooperação. Circuitos espaciais de produção e círculos de cooperação mostram o uso diferenciado de cada território por parte das empresas, das instituições, dos indivíduos e permitem compreender a hierarquia dos lugares desde a escala regional até a escala mundial. (SANTOS; SILVEIRA, op. cit., p. 144).

Essa é a ponte entre o local e o regional com o nacional e o global, pois se do ponto de vista da produção há a necessidade das especializações produtivas, e essas buscam os lugares luminosos para a inversão de investimentos, a reprodução do capital depende da completude do processo de produção, circulação e consumo. Com isso, torna-se necessário a existência de um conjunto sincronizado entre a produção - nos diversos circuitos produtivos que se sobrepõem aos lugares -, a inteligência e o controle, condição intrínseca aos círculos de cooperação. Passa a ser diretamente proporcional a relação entre a diversidade de produção nos circuitos e a densidade das informações, capitais e ordens emanadas, normalmente para fora do país.

A busca pela competitividade em um cenário de escala global exige a criação de estratégias diversas, e assim, a densidade de circuitos produtivos pode determinar as condições de manutenção nesse ambiente de competição extremada.

Para os produtores do interior de Mato Grosso, afastados dos mercados consumidores, a composição da produção, ou seja, aquilo que pode ser agregado em termos de valores ao produto, pode ser uma saída para uma crise de acumulação gerada pelos custos de produção e de transporte. 
Bernardes (2008) trata da crise no agronegócio argumentando que o setor produtivo aponta a falta de poupança do produtor como elemento nodal desse problema. $\mathrm{O}$ fenômeno estrutura-se da seguinte forma: por não especular no mercado há a necessidade de reinvestimento total do capital, gerando crise de liquidez. Com a expansão contínua da produção, face à densidade técnica destinada à mesma, ocorre a queda de preços. Além deste cenário de insegurança, outros fatores, cujo controle não depende do produtor, também interfere no processo, caso das precárias condições de infraestrutura, como dos transportes e da questão cambial. A competitividade vê-se ameaçada nesse contexto.

O processamento via industrialização da produção, caso das agroindústrias, pode ser uma alternativa para alcançar os acréscimos reais que permitam diversificar a gama de produtos oferecidos para além das exportações de grãos, carro-chefe das exportações de Mato Grosso. A criação de cadeias produtivas, como a de carne e grãos, representa alternativas para o setor produtivo, porém exige alta capitalização dos produtores ou, ainda, a entrada de capitais interessados no potencial produtivo e de retorno dos investimentos. Trata-se, pois, de um processo seletivo, devido às condições técnicas e de capitais envolvidos, atraindo normalmente agentes privados capitalizados ou com acesso aos recursos financeiros disponíveis para o setor produtivo.

Nesse sentido Bernardes (2008, p. 256) responde qual é o perfil dos agentes mais qualificados para adotar essa estratégia:

Sem dúvida aqueles empresários que têm condições de participar da instituição e da distribuição de novos objetos, que exigem novas ações, em relação a um plano racionalmente traçado, com vistas à reprodução de um mesmo processo, que é a produção de grãos, mas agora em um novo espectro de ação econômica, que é a cadeia carne/grãos.

Como resultado, temos uma nova organização do capital, em que ocorrem a concentração e a centralização do capital, em um menor número de empresas, convergindo para a criação de monopólios. A autora chama atenção para a mudança inclusive do desenho espacial da produção, deixando de organizar-se em linha junto aos eixos de escoamento, para criar as ilhas de produção que demandam novas relações entre as empresas e interações entre os lugares originando novas hierarquias entre esses elementos. 
Fica evidente a complexificação do novo cenário na medida em que se exige, para agregar valor, a concepção de novas relações e interações de diversas naturezas. Isso implica que os círculos de cooperação sejam adensados para proporcionar a racionalidade capitalista que o sistema impõe, porque a quantidade de agentes envolvidos cresce pela natureza da atividade, como é o caso dos integrados da cadeia carne e grãos. A condição de concentração e centralização de capitais que vem à tona ocorre em escalas diversas, mas considerando a composição da produção, voltada para os mercados internacionais, a influência do capital global é bastante incisiva nas ações com repercussões territoriais diretas.

Entre as repercussões temos aquelas relativas às condições da apropriação da força de trabalho, pois à medida que o processo se globaliza, as especificidades surgem e necessitam ser entendidas nas suas singularidades, mas também demanda a busca por uma padronização mínima de produtividade e controle das ações.

Sobre o processo de concentração e centralização do capital global e a apropriação da força de trabalho nessas condições, Benko (2002, p. 45) indica a existência de um duplo movimento, representado pela "descentralização-disseminação" das cadeias produtivas, a intensificação da especialização geográfica, a deslocalização das empresas na busca por melhores oportunidades tanto de mercado como de lucros nas escalas locais e nacionais. Esse conjunto exige coordenação, por isso temos o desenvolvimento:

[...] de vastas e eficazes estruturas de coordenação e controle dos mesmos sítios e unidades de produção que são objeto de fragmentação e de reorganização, evolução que permite circulação bem mais flexível do capital e das mercadorias no interior de seus "impérios" (BENKO, op. cit. p. 45).

Estamos diante de uma condição que transcende as diversas escalas, portanto as estratégias pensadas pelo agente capitalista da escala global também é reproduzida na escala nacional e local tendo em vista a articulação entre as diversas escalas.

No caso das cadeias produtivas estabelecidas no Cerrado mato-grossense, os agentes nacionais, representados por empresas como BRF (Sadia e Perdigão), Alibem, Vanguarda e JBS Friboi, para citar a cadeia carne e grãos e os players ADM, Bunge, Louis Dreyfus e Cargill, necessitam articular seus interesses globais e nacionais com a produção territorializada na forma das agroindústrias instaladas. Em todos os níveis as relações campo 
(área de produção) e cidade (área da gestão, planejamento - inteligência) são complexificadas, como aponta Bernardes (2010, p. 15):

\begin{abstract}
A cada novo impulso de modernização as forças produtivas agroindustriais vêm se reorganizando, apresentando maior complexidade, o que pode ser detectado através dos novos circuitos espaciais de produção e dos círculos de cooperação que se estabelecem entre campo e cidade.
\end{abstract}

Estamos discutindo aqui a questão da cadeia carne e grãos por envolver a produção de grãos que hegemoniza o setor do agronegócio em Mato Grosso e porque, conforme argumenta Bernardes (2015, p. 20) com essa cadeia produtiva temos a ascensão de "[...] uma estrutura produtiva mais articulada no cerrado do Centro-Oeste, atingindo-se um patamar mais intenso da cooperação capitalista". Logo, se faz necessário discutir os circuitos espaciais da produção e os círculos de cooperação, pois a sua compreensão possibilita entender a nova realidade produtiva que se impõe com a criação e consolidação dessas novas estruturas.

Conforme nos ensina Santos (2012, p. 56), teríamos obrigatoriamente que seguir a trilha do processo, indo da produção em si, enquanto matéria-prima, com toda a sua cadeia de produção (insumos diversos), a condição de transporte da primeira etapa, composição da mão de obra, armazenamento, transportes (no segundo estágio), comercialização, taxações, tipo de consumo (produtivo ou consumitivo). Espacialmente poderemos ter inclusive a convergência desse processo, pois "Uma mesma área, hoje, pode ser o ponto de confluência de diversos circuitos produtivos. Numa mesma região realizam-se diferentes fases de distintos circuitos de produção", assim, somando os circuitos espaciais da produção e os círculos de cooperação numa mesma análise, teremos a organização local (tornada periférica por não ter plenitude no poder de mando) e a sua condição na hierarquia global.

Castillo (2008, p. 404) aborda a condição das formações socioespaciais periféricas frente ao novo cenário global, entendendo que nessas "os fundamentos da globalização se estabelecem de forma mais pura, portanto mais perversa", entre outros motivos pela fragilidade das condições de autodeterminação do desenvolvimento. Nesse contexto exemplifica essa situação com as condições brasileiras: 
Talvez nada expresse melhor essa situação do que a articulação no território brasileiro de três variáveis: o agronegócio, a região competitiva e a logística moderna. Sinteticamente, a expansão do agronegócio (com o aporte da ciência, da informação e de generosos incentivos do Estado) sobre áreas com precárias infra-estruturas de transporte e armazenamento, sob forte concentração fundiária, urbanização dispersa, distante dos principais centros consumidores do país e dos portos exportadores - como vem ocorrendo em vastas porções do cerrado -, cria as condições ideais para a emergência de regiões agrícolas competitivas e a ampliação dos circuitos espaciais de commodities. (CASTILLO, op. cit. p. 404-405).

O autor ainda aponta que os circuitos espaciais da produção decorrentes deste processo são dominados pelas tradings agrícolas em praticamente todas as suas etapas. Logo os círculos de cooperação estabelecidos possuem fluxos extrovertidos que organizam remotamente as condições da produção pela abrangência apresentada.

A qualidade dos fluxos - entendida enquanto composição de capitais, informações e comandos e suas respectivas organicidades -, exige condições técnicas equivalentes. $\mathrm{O}$ mesmo ocorre com a produção, base essencial da existência dos circuitos espaciais da produção, pois o seu direcionamento para mercados externos demanda da mesma forma as condições de circulação adequadas. Nesse contexto, as infraestruturas de transportes e de armazenagem necessitam de condições satisfatórias para garantir a operacionalidade do processo.

Mas nesse ponto chegamos à contradição do processo, pois a precariedade e insuficiência dessas infraestruturas corrompe a fluidez necessária e cria os gargalos logísticos. Esses se tornam ruídos na dinâmica produtiva, encarecendo os custos e prejudicando a reprodução satisfatória do capital empregado na produção. Daí surge parte da crise do agronegócio (BERNARDES, 2008) já abordada anteriormente.

Assim, a complexificação dos fluxos aumenta com o processamento da produção primária via industrialização, que faz parte de alguns circuitos espaciais da produção. Na Tabela 2, é possível observar a participação de Mato Grosso na produção industrial nacional dos itens mais representativos.

Apesar dos dados se referirem ao ano de 2011, data da pesquisa do IBGE, entendemos ser salutar a sua análise, visto que a dinâmica da produção industrial em Mato Grosso não apresentou alterações estruturais significativas, principalmente dos seus fluxos, e também porque ainda complementaremos a análise do setor industrial ao discutirmos a questão do PIB 
industrial (com dados até 2012) e as exportações da agroindústria nos eixos mais dinâmicos do estado (com dados até 2014).

\section{Tabela 2 - Produção e vendas dos maiores produtos e serviços industriais com participação de Mato Grosso em 2011}

\begin{tabular}{|c|c|c|c|c|c|c|c|c|c|c|}
\hline \multirow{2}{*}{$\begin{array}{l}\text { Descrição do produto e total geral do Brasil por setor } \\
\text { Unidade da Federação e posição quanto à produção }\end{array}$} & \multirow{2}{*}{$\begin{array}{c}\text { Unidade } \\
\text { de } \\
\text { medida }\end{array}$} & \multirow{2}{*}{\begin{tabular}{c|} 
№ \\
de \\
informações
\end{tabular}} & \multicolumn{4}{|c|}{ Produção } & \multicolumn{4}{|c|}{ Vendas } \\
\hline & & & Qtde & $\%$ & Valor mil R\$ & $\%$ & Qtde & $\%$ & Valor mil R\$ & $\%$ \\
\hline Álcool etílico, anidro ou hidratado para fins carburantes & mill & 307 & 20595110 & 100 & 25322839 & 100 & 21537796 & 100 & 25960268 & 8100 \\
\hline Mato Grosso (6a posição, qtde produzida) & & 7 & 631318 & 3,1 & 848413 & 3,4 & 585656 & 2,7 & 785182 & 23 \\
\hline Carnes de bovinos frescas ou refrigeradas & $\mathrm{t}$ & 282 & 4675383 & 100 & 27930458 & 3100 & 4046142 & 100 & 24131151 & 1100 \\
\hline Mato Grosso (2a posição, qtde produzida) & & 20 & 760617 & 16 & 4389481 & 16 & 564506 & 14 & 3268485 & $5 \quad 14$ \\
\hline Cervejas ou chope & mill & 73 & 13743457 & 100 & 21898158 & 100 & 12504104 & 100 & 19456640 & 0100 \\
\hline Mato Grosso (6a posição, qtde produzida) & & 3 & 538635 & 3,9 & 1356627 & 6,2 & 541072 & 4,3 & 1364494 & 7 \\
\hline Adubos ou fertilizantes com (NPK) & $\mathrm{t}$ & 133 & 18944452 & 100 & 17181806 & 100 & 20088351 & 100 & 18208536 & 6100 \\
\hline Mato Grosso (5a posição, qtde produzida) & & 10 & 1158667 & 6,1 & 1327712 & 7,7 & 1261587 & 6,3 & 1491274 & 48,2 \\
\hline Açúcar cristal & $\mathrm{t}$ & 174 & 17536177 & 100 & 18014942 & 100 & 16652203 & 100 & 17054921 & 1100 \\
\hline Mato Grosso (7a posição, qtde produzida) & & 5 & 443687 & 2,5 & 490250 & 2,7 & 475361 & 2,9 & 528683 & 33,1 \\
\hline Refrigerantes & mill & 194 & 16725173 & 100 & 18547626 & 5100 & 15025734 & 100 & 16382716 & 6100 \\
\hline Mato Grosso (13a posição, qtde produzida) & & 3 & 313558 & 1,9 & 325716 & 1,8 & 322253 & 2,1 & 336043 & 32,1 \\
\hline Tortas, bagaços, farelos da extração do óleo de soja & $\mathrm{t}$ & 78 & 21993261 & 100 & 15336362 & 100 & 19104287 & 100 & 13113372 & 2100 \\
\hline Mato Grosso (3a posição, qtde produzida) & & 8 & 4230282 & 19 & 2993073 & 20 & 3754199 & 20 & 2705216 & 621 \\
\hline Carnes ou miudezas de aves congeladas & $\mathrm{t}$ & 164 & 7868773 & 100 & 24839495 & 100 & 4427054 & 100 & 13098892 & 2100 \\
\hline Mato Grosso (7a posição, qtde produzida) & & 9 & 373515 & 4,7 & 904285 & 3,6 & 132185 & 3 & 308785 & $5 \quad 2,4$ \\
\hline Carnes de bovinos congelada & $\mathrm{t}$ & 111 & 1964970 & 100 & 11053325 & 100 & 1596794 & 100 & 9387168 & 8100 \\
\hline Mato Grosso (2a posição, qtde produzida) & & 14 & 463248 & 24 & 2952297 & 27 & 211424 & 13 & 1301033 & 314 \\
\hline Rações e preparações usadas na alimentação de animais & $\mathrm{t}$ & 401 & 30033944 & 100 & 28033475 & 100 & 8698675 & 100 & 9252742 & 2100 \\
\hline Mato Grosso (7a posição, qtde produzida) & & 19 & 1261282 & 4,2 & 689605 & 2,5 & 390335 & 4,5 & 322682 & 23,5 \\
\hline Massa de concreto para construção; concreto usinado & $\mathrm{m}^{3}$ & 518 & 27863425 & 100 & 7187958 & 3100 & 27822620 & 100 & 7180593 & 3100 \\
\hline Mato Grosso (13a posição, qtde produzida) & & 10 & 220614 & 0,8 & 57934 & 0,8 & 220614 & 0,8 & 57934 & 40,8 \\
\hline Leite esterilizado / UHT/ Longa Vida & mill & 118 & 5310985 & 100 & 7519454 & 100 & 4172170 & 100 & 5926440 & 0100 \\
\hline Mato Grosso (7a posição, qtde produzida) & & 4 & 146340 & 2,8 & 152116 & 2 & 145704 & 3,5 & 151153 & 32,6 \\
\hline Biodiesel & $\mathrm{kg}$ & 39 & 2979114363 & 100 & 6045669 & 100 & 2892898705 & 100 & 5871612 & 2100 \\
\hline Mato Grosso (2a posição, qtde produzida) & & 9 & 612582740 & 21 & 1069506 & 518 & 560876634 & 19 & 977249 & $9 \quad 17$ \\
\hline Óleo de soja refinado & $\mathrm{t}$ & 43 & 2734160 & 100 & 6611123 & 100 & 2130829 & 100 & 5438060 & 0100 \\
\hline Mato Grosso (1a posição, qtde produzida) & & 6 & 867480 & 32 & 1998741 & 30 & 604461 & 28 & 1532332 & 228 \\
\hline Óleo de soja em bruto, mesmo degomado & $\mathrm{t}$ & 73 & 5135504 & 100 & 10681923 & 100 & 2410756 & 100 & 4810150 & 0100 \\
\hline Mato Grosso (1ạ posição, qtde produzida) & & 7 & 1089906 & 21 & 2835220 & 27 & 243345 & 10 & 732010 & 015 \\
\hline Arroz semibranqueado ou branqueado, polido, parboilizado ou não & $\mathrm{t}$ & 143 & 4609648 & 100 & 5574900 & 100 & 4035559 & 100 & 4718443 & 3100 \\
\hline Mato Grosso (6a posição, qtde produzida) & & 9 & 129735 & 2,8 & 159264 & 2,9 & 128567 & 3,2 & 158658 & 83,4 \\
\hline Pedras britadas & $\mathrm{m}^{3}$ & 356 & 138536535 & 100 & 4484910 & 100 & 122103659 & 100 & 3912044 & 4100 \\
\hline Mato Grosso (14ª posição, qtde produzida) & & 7 & 1335947 & 1 & 23390 & 0,5 & 1304618 & 1,1 & 22813 & 30,6 \\
\hline Chapas, bobinas, fitas e tiras de aço, relaminadas & $\mathrm{t}$ & 170 & 1513292 & 100 & 3550196 & 100 & 1386096 & 100 & 3268859 & 9100 \\
\hline Mato Grosso (7ạ posição, qtde produzida) & & 4 & 31205 & 2,1 & 37855 & 1,1 & 31201 & 2,3 & 37834 & $4 \quad 1,2$ \\
\hline
\end{tabular}

Fonte: IBGE, Diretoria de Pesquisas, Coordenação de Indústria, Pesquisa Industrial Anual - Produto 2011, 2011 
Em estudo específico da produção industrial para o ano de 2011, o IBGE (2011) listou os 100 maiores produtos e/ou serviços industriais. Do total elencado, os 18 itens em que o estado de Mato Grosso teve participação em destaque compunham, no seu conjunto, $22 \%$ da produção industrial brasileira e das vendas do setor. Analisando o conjunto dos itens da Tabela 2, é possível observar que dos itens apontados temos a seguinte composição:

- Combustíveis (Álcool etílico, anidro ou hidratado para fins carburantes; Biodiesel) 2 itens;

- Alimentos (Carnes de bovinos frescas ou refrigeradas; Cervejas ou chope; Açúcar cristal; Refrigerantes; Carnes ou miudezas de aves congeladas; Carnes de bovinos congelada; Leite esterilizado / Ultra High Temperature (UHT)/ Longa Vida; Óleo de soja refinado; Arroz semibranqueado ou branqueado, polido, parboilizado ou não) - 9 itens;

- Materiais de construção (Massa de concreto para construção e concreto usinado; Pedras britadas) - 2 itens;

- Insumos (Adubos ou fertilizantes com Nitrogênio, Fósforo e Potássio (NPK); Tortas, bagaços, farelos da extração do óleo de soja; Rações e preparações usadas na alimentação de animais; Óleo de soja em bruto, mesmo degomado) - 4 itens;

- Usos diversos (Chapas, bobinas, fitas e tiras de aço, relaminadas) - 1 item;

Observamos que no grupo composto pelos materiais de construção, Mato Grosso tem pequena participação no total nacional, ou seja, essa produção atende primordialmente o mercado local e suas necessidades, pois os custos de transporte inviabilizam sua movimentação para áreas mais distantes. Outro item de pequeno vulto é a produção de materiais a partir do aço, pois mesmo Mato Grosso sendo o $7^{\circ}$ produtor nacional desse setor, não produz mais que $2,1 \%$ do total nacional. Nesse caso a matéria-prima do setor não é produzida no estado e a produção também é voltada para atender a demanda doméstica. 
Em virtude da escala de produção agrícola existente em Mato Grosso, a qual o torna o maior consumidor de fertilizantes do Brasil, o estado posiciona-se como o $5^{\circ}$ maior produtor de fertilizantes do grupo composto por nitrogênio, fósforo e potássio (NPK) com 6,1\% da produção nacional.

A produção de álcool e de açúcar cristal leva o estado de Mato Grosso a ocupar a $6^{\mathrm{a}} \mathrm{e}$ $7^{\mathrm{a}}$ colocações na produção, porém a participação no total nacional é pequena com $3,1 \%$ e 2,5\% respectivamente. Este setor apresenta uma elevada concentração, pois ao contrário da produção de grãos, se restringe a uma área menor devido entre outros fatores às restrições do zoneamento agroecológico. De acordo com Monteiro (2012, p. 25) quando as benesses dos programas governamentais deixaram de existir, muitos empreendimentos fecharam. Assim, surge a reestruturação produtiva e um novo ciclo emerge.

O autor destaca dois padrões de usinas: as mais antigas, que concentram a maior parte da produção, como a Usina Itamarati e a Usina Barrálcool (que respondiam juntas por 52,6\% e 66,3\% das produções de etanol e de açúcar em 2010), principalmente pela capacidade de esmagamento da primeira, de sete milhões de toneladas por ano; e de usinas oriundas da reestruturação produtiva, como a usina flex em Campos de Júlio, capaz de utilizar várias matérias-primas, e a Usina ETH Bioenergia em Alto Taquari, caracterizada como uma corporação em rede, já que faz parte de um projeto maior envolvendo unidades em outros locais.

Outro item elencado, a produção de cervejas ou chope e refrigerantes, também apresenta expressividade pequena, atendendo o mercado local e a região de entorno. A concentração espacial das plantas industriais é outra característica, pois as mesmas estão estabelecidas em Cuiabá, Várzea Grande e Rondonópolis.

No grupo dos alimentos, o beneficiamento do arroz apresenta uma produção de 129.735 toneladas, equivalente a 2,8\% da produção nacional. Segundo estudos de Beckmann (2011, p. 71) sobre a cadeia produtiva do arroz, o beneficiamento se dá principalmente em um grupo de 23 municípios, havendo uma concentração nas áreas do Médio-Norte e no centro do estado (Sinop. Sorriso, Nova Mutum, Diamantino, Rosário Oeste e Várzea Grande), do Norte (Alta Floresta, Carlinda, Colíder, Guarantã do Norte, Matupá e Peixoto de Azevedo) e do Leste (Canarana, Água Boa, Nova Xavantina e Barra do Garças). Isoladamente no Sul temos Rondonópolis. O beneficiamento de arroz segue a lógica das áreas da produção agrícola e, 
também, a lógica do mercado consumidor, daí a presença de Várzea Grande e Rondonópolis que processam o arroz para a distribuição em suas regiões de influência.

Na cadeia produtiva do leite, com uma produção superior a 145 milhões de litros de leite Longa Vida, UHT e esterilizado, Mato Grosso ocupa a $7^{\text {a }}$ posição no ranking nacional participando com apenas 2,8\% da produção brasileira. Esse setor é importante porque drena a produção das bacias leiteiras do estado, onde grande parte da produção provém de pequenos produtores. A industrialização do leite se dá em dois segmentos, o das indústrias particulares e o de cooperativas.

Quanto à produção do leite esterilizado UHT longa vida, segundo estudos da Famato; Senar-MT; Sescoop-MT (2011), as indústrias particulares comercializam cerca de $10 \%$ da produção em Mato Grosso e 90\% em outros estados. Já as cooperativas destinam 65\% da produção ao mercado interno, vendendo para outros estados 35\%. Espacialmente a indústria laticinista encontra-se dispersa por uma extensa área do estado, acompanhando a produção de leite também dispersa.

A lógica é evidente, pois quanto maior a distância da área de produção para a indústria, maior é o custo, assim cria-se uma dispersão espacial e uma capilaridade bem densa dos fluxos desse circuito que convergem para as instalações processadoras. $\mathrm{O}$ uso das estradas vicinais, normalmente conformadas em leito natural, é prejudicado no período das chuvas, exatamente na época de maior intensidade do tráfego por conta do aumento da produção.

Os demais itens elencados na Tabela 2, merecem uma análise mais pormenorizada, pois se trata dos dois principais setores produtivos da indústria mato-grossense, representados pelos complexos da soja e da carne.

A produção de rações e preparações usadas na alimentação de animais tem uma estreita relação com esses complexos, pois os grãos são os principais insumos das rações e essas alimentam os rebanhos de aves, suínos, peixes e bovinos confinados, proporcionando a conversão da proteína vegetal em proteína animal e expandindo a gama de produtos disponibilizados aos mercados consumidores.

No conjunto temos a cadeia carne e grãos que representa um importante movimento de reestruturação produtiva, pelo qual passa as áreas mais dinâmicas do território matogrossense. 
Essa reestruturação resulta da busca por maior competitividade nos mercados internacionais, já que a produção decorrente dessa cadeia é voltada à exportação, prescindindo assim de conexões mais amplas. Assim, temos a materialização dos circuitos espaciais da produção e dos círculos de cooperação no contexto da atividade produtiva dessas áreas.

A produção da carne bovina é bastante representativa em Mato Grosso, pois o estado é o segundo maior produtor em dois itens relacionados:

- Carnes de bovinos frescas ou refrigeradas, com uma produção de 760.617 toneladas, equivalendo a $16 \%$ da produção nacional;

- Carnes de bovinos congeladas, representando $24 \%$ do total nacional com 463.248 toneladas produzidas.

Pelo volume da produção existente, tanto o mercado interno como o mercado externo são atendidos, sendo que para este há toda uma estruturação das condições de produção e um maior controle, pois atende ao controle de qualidade internacional.

De acordo com a Associação Brasileira das Indústrias Exportadoras de Carne (ABIEC, 2014) em 2014, Mato Grosso contava com 26 unidades aptas à exportação da produção por atenderem os critérios do Sistema de Inspeção Federal (SIF) do Ministério da Agricultura, Pecuária e Abastecimento (MAPA) que regulamenta o setor quanto à condição sanitária.

O Quadro 6, apresenta o conjunto dos frigoríficos, exportadores e não-exportadores, que se encontra distribuído em 27 municípios do estado, devidamente instalados próximos às áreas de maior concentração do rebanho bovino e das principais vias de escoamento, nesse caso as rodovias federais.

Quanto aos rebanhos, encontram-se localizados principalmente no Norte e Noroeste do estado e na área do Pantanal, como pode ser observado no Mapa 3. 
Quadro 6 - Frigoríficos de carne bovina em Mato Grosso com registro no SIF em 2014

\begin{tabular}{|c|c|c|c|c|c|}
\hline MUNICÍPIO & ESTABELECIMENTO & SIF & $\begin{array}{c}\text { EXPORTOU } \\
\text { em } 2014\end{array}$ & $\begin{array}{c}\text { EXPORTOU } \\
\text { em } 2013\end{array}$ & $\begin{array}{c}\text { EXPORTOU } \\
\text { em } 2012\end{array}$ \\
\hline Água Boa & JBS S/A & 4121 & Sim & Sim & Sim \\
\hline Alta Floresta & JBS S/A & 4302 & Sim & Sim & Sim \\
\hline Araputanga & JBS S/A & 2979 & Sim & Sim & Sim \\
\hline Barra do Garças & JBS S/A & 42 & Sim & Sim & Sim \\
\hline Barra do Garças & Frigorífico Margen Ltda & 3964 & Não & Não & Não \\
\hline Cáceres & JBS S/A & 2837 & Não & Não & Não \\
\hline Canarana & Frigorífico Margen Ltda & 3743 & Não & Não & Não \\
\hline Colider & JBS S/A & 2601 & Não & Não & Não \\
\hline Colider & JBS S/A & 4268 & Sim & Sim & Sim \\
\hline Confresa & JBS S/A & 3470 & Sim & Sim & Sim \\
\hline Cuiabá & JBS S/A & 826 & Sim & Sim & Sim \\
\hline Diamantino & JBS S/A & 3000 & Sim & Sim & Sim \\
\hline Guarantã do Norte & Frigorífico Redentor S/A & 411 & Sim & Sim & Não \\
\hline Juara & JBS S/A & 200 & Sim & Sim & Sim \\
\hline Juara & Pantanal Ind. Com. Carnes Ltda & 2727 & Não & Não & Não \\
\hline Juína & JBS S/A & 2942 & Sim & Sim & Sim \\
\hline Juruena & JBS S/A & 2011 & Não & Sim & Sim \\
\hline Matupá & JBS S/A & 4323 & Sim & Sim & Sim \\
\hline Matupá & Vale Grande Ind. Com. Alimentos S/A - Frialto & 4490 & Sim & Sim & Sim \\
\hline Mirassol D’Oeste & Minerva S/A & 2911 & Sim & Sim & Sim \\
\hline Nova Canaã do Norte & Vale Grande Ind. Com. Alimentos S/A - Frialto & 2937 & Não & Não & Não \\
\hline Nova Xavantina & Marfrig Global Foods S/A & 2345 & Não & Não & Não \\
\hline Paranatinga & Marfrig Global Foods S/A & 2500 & Sim & Não & Sim \\
\hline Pedra Preta & JBS S/A & 2019 & Sim & Sim & Sim \\
\hline Pontes e Lacerda & JBS S/A & 51 & Sim & Sim & Não \\
\hline Rondonópolis & Agra Agroindustrial de Alimentos S/A & 3941 & Sim & Sim & Sim \\
\hline Rondonópolis & Frigorífico Mataboi S/A & 1886 & Sim & Sim & Não \\
\hline Rondonópolis & Superfrigo Ind. Com. S/A & 4466 & Sim & Sim & Sim \\
\hline S. J. Quatro Marcos & JBS S/A & 3031 & Sim & Sim & Sim \\
\hline Sinop & Rodopa Exp. Alim. Logística Ltda - Tatuibi & 2819 & Não & Não & Não \\
\hline Sinop & Nortão Ind. - Vale Grande Ind. Com. Alim. - Frialto & 3348 & Sim & Sim & Sim \\
\hline Tangará da Serra & Marfrig Global Foods S/A & 1751 & Sim & Sim & Não \\
\hline Várzea Grande & Frical Frigoríficos Ltda & 4656 & Não & Não & Não \\
\hline Várzea Grande & Carnes Boi Branco Ltda & 2862 & Não & Não & Não \\
\hline Várzea Grande & Minerva S/A & 2015 & Sim & Sim & Não \\
\hline Várzea Grande & Frigosul - Frigorífico Sul Ltda & 1869 & Sim & Sim & Não \\
\hline Vila Rica & JBS S/A & 4393 & Sim & Sim & Não \\
\hline
\end{tabular}

Fontes: Ministério do Desenvolvimento, Indústria e Comércio Exterior - Empresas brasileiras exportadoras e importadoras (2012, 2013 e 2014); Associação Brasileira das Indústrias Exportadoras de Carne - ABIEC (2014) e Ministério da Agricultura, Pecuária e Abastecimento - Consulta de estabelecimento nacional (2015). 
Mapa 3 - Mato Grosso: rebanho bovino em 2013 e frigoríficos em 2014

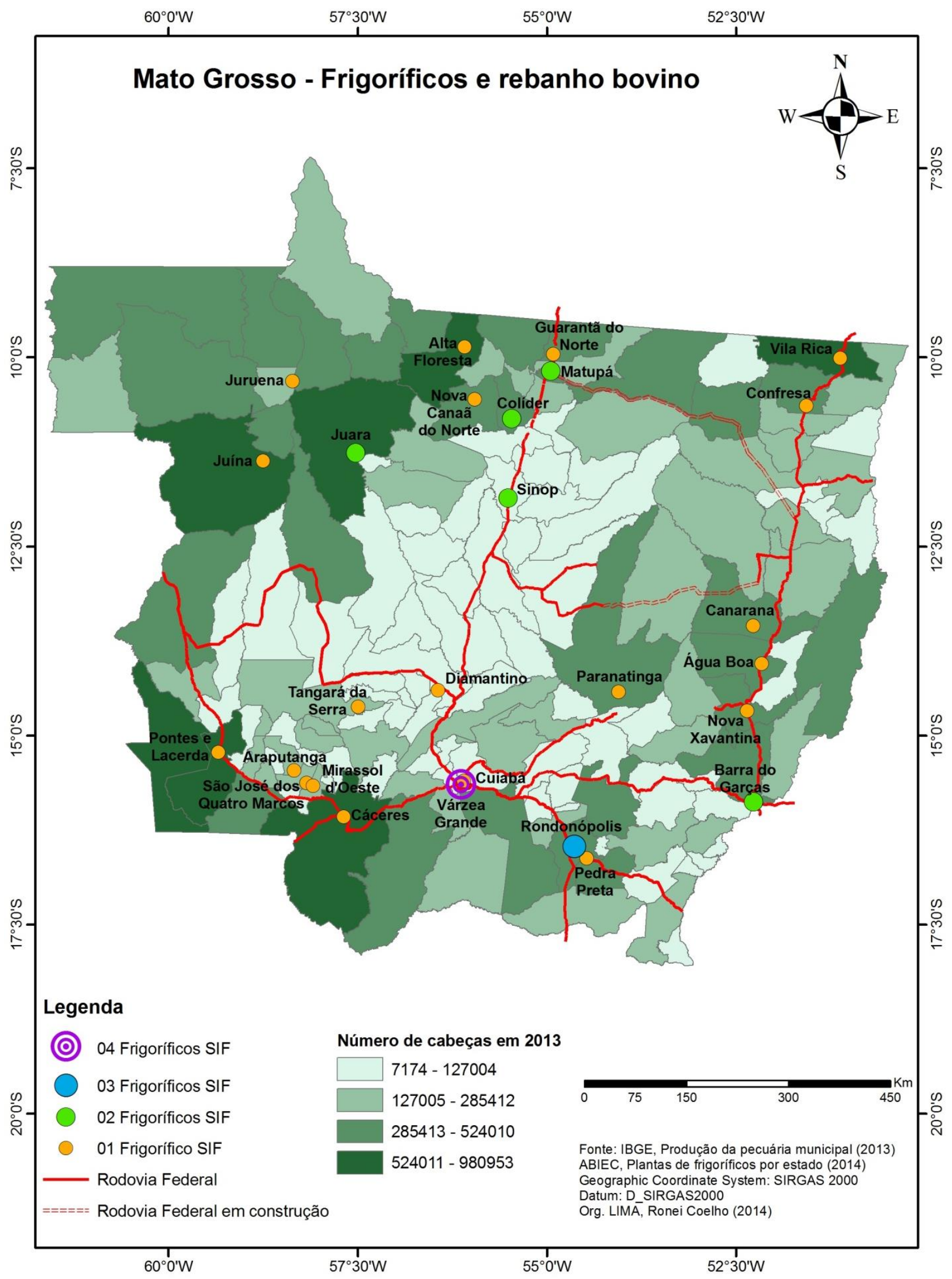

Fonte: IBGE, Pecuária (2013); ABIEC (2014) 
Quanto à destinação da carne para o mercado externo, de acordo com dados do Instituto Mato-Grossense de Economia Agropecuária - IMEA (2015a), em 2014, Mato Grosso exportou $18,2 \%$ do total nacional, sendo a Venezuela, a China e a Rússia, os principais compradores da carne produzida no estado. Mato Grosso se consolidou como o segundo maior exportador de carne bovina em 2014, ficando atrás apenas de São Paulo que respondeu por $28 \%$ do total nacional. Esse fluxo segue no sentido Sul, tendo os portos de São Francisco do Sul (SC) com 46\% e Santos (SP) com 31\% do total das exportações como as principais rotas da produção. É importante destacar a baixa utilização da capacidade instalada de abate dos frigoríficos com habilitação da inspeção federal em Mato Grosso, que não ultrapassa os 46,3\% de média no ano de 2014. No entanto, essa utilização possui uma variação bem acentuada, pois enquanto a região Nordeste de Mato Grosso apresentou uma média de $34 \%$ de utilização das instalações frigoríficas, o Noroeste do estado chegou a atingir uma média de $88 \%$ em 2014.

Em suma, para o setor da produção de carnes bovinas no estado de Mato Grosso observa-se duas características principais: a concentração da produção com a JBS Friboi (18 frigoríficos) - já considerada a maior empresa do setor nas escalas nacional e internacional seguida pela Marfrig Global Foods S/A (03 frigoríficos) que cria uma insatisfação por parte dos produtores já que a pouca concorrência de um mercado oligopsônico pode levar a uma pressão de baixa de preços; outro fator é a ociosidade de parte das plantas existentes, o que denota um descompasso entre a produção no campo (cria, recria e engorda - nos sistemas extensivo e intensivo) e a produção industrial, notadamente aquela mais estruturada e controlada de acordo com os padrões internacionais de abate e exportação que possuem o certificado de inspeção SIF.

Como resultado de fatores conjunturais, as plantas frigoríficas da Superfrigo e Mataboi, em Rondonópolis, da Minerva, em Mirassol D’Oeste, da Frialto em Sinop, e da JBS Friboi em Vila Rica, São José dos Quatro Marcos, Cuiabá e Matupá se encontravam fechadas no fim do primeiro semestre de 2015 pela falta de gado para abate e por reestruturações internas, como no caso do grupo JBS Friboi. O setor de frigoríficos apresenta uma dinâmica de fechamentos e reaberturas que estão em consonância com as condições financeiras dos diversos grupos do setor e das vantagens comerciais que emergem, como a abertura de novos mercados para exportação da carne ou o aquecimento do mercado interno, quando grupos mais estruturados alugam ou compram as plantas dos grupos endividados. 
Outra condição está relacionada à associação entre grandes grupos, em Mato Grosso as unidades de bovinos da BRF de Várzea Grande e de Mirassol D’Oeste foram vendidas para o grupo Minerva S/A, umas das empresas líderes na produção de carne da América do Sul, em troca da participação da primeira no capital da segunda, com isso as empresas podem se estruturar no mercado mato-grossense hoje dominado pela JBS.

A dinâmica das empresas segue o que Santos e Silveira (2004, p. 292) apontam como sendo a "lógica territorial das empresas", que é “[...] visível por meio do que se pode considerar uma topologia, isto é, a distribuição no território dos pontos de interesse para a operação dessa empresa". Assim, a racionalização do uso dos fixos existentes está diretamente relacionada à otimização da produção, da mesma forma o encerramento das atividades de uma planta industrial, por mais impactos que possam trazer aos lugares, está em consonância com as estratégias corporativas mais amplas, e assim não há uma preocupação em relação aos rebatimentos negativos nas sociedades locais decorrentes das ações corporativas.

Outro ponto importante é o alcance da produção industrial, espacializada de acordo com as diversas áreas de produção do campo, havendo uma justaposição dos setores que se complementam e reforçam a característica de circuito espacial da produção, conforme pode ser observado na Figura 3.

\section{Figura 3 - Circuito espacial da produção de carne bovina em Mato Grosso}

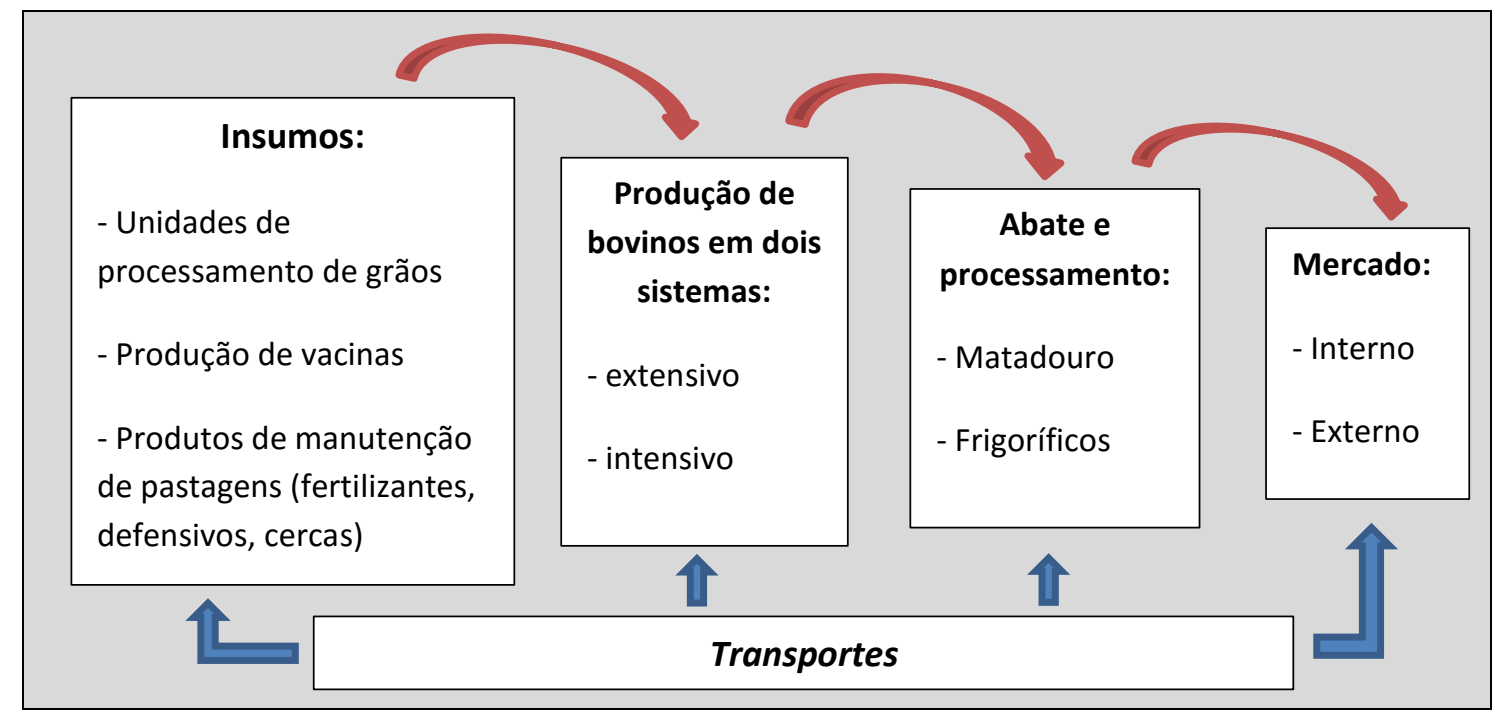

Fonte: ARACRI, Luís A. dos Santos; MOREIRA, Fernando de S., 2010 Dados organizados por LIMA, Ronei Coelho de. (2014) 
Elemento nodal do processo produtivo, os transportes atendem às diversas demandas, pois permite a circulação de insumos e de mercadorias acabadas nos diversos estratos da produção, ou seja, tanto no nível interno como entre os setores, criando assim os fluxos necessários à completude dos circuitos produtivos.

Os últimos itens que serão analisados constituem-se no complexo da soja, pois derivam do seu processamento gerando combustíveis (biodiesel), alimentos (óleo de soja refinado) e insumos (tortas, bagaços, farelo de soja e óleo de soja bruto mesmo degomado). Esses itens são os mais representativos, pois contribuem significativamente na pauta de exportações do estado, além de constituírem-se nos mais elevados índices de participação do estado a nível nacional.

O melhor índice é o do óleo de soja refinado com uma participação de $32 \%$ da produção nacional o que confere a $1^{a}$ posição do ranking nacional. É a mesma posição da produção de óleo de soja em bruto, porém esse possui uma representação de $21 \%$ do total geral. Na $2^{a}$ posição da produção de biodiesel, Mato Grosso participa também com $21 \%$ da produção nacional. Finalmente a torta, bagaço e farelo de soja respondem por $19 \%$ da produção brasileira conferindo ao estado a $3^{\mathrm{a}}$ posição no cômputo nacional.

O complexo da soja pode ser considerado como o motor do atual estágio da economia mato-grossense, pois o estado é o maior produtor nacional dessa commodity e inicia lentamente um processo de reorganização produtiva com vistas a gerar maior valor agregado à produção e reduzir as fragilidades do mercado reduzido a um só produto.

Algumas áreas oferecem melhores condições para esse processo de reorganização produtiva, como é o caso: de Rondonópolis com o perfil mais industrial, do eixo Primavera do Leste-Campo Verde, e principalmente do eixo Nova Mutum-Lucas do Rio Verde-SorrisoSinop que emerge como a área mais dinâmica desse processo.

De acordo com Bernardes (2010, 16-17), isso ocorre por se tratar da área concentrada da soja, onde questões como o surgimento de novos agentes interessados na escala de produção e na proximidade das matérias-primas, na técnica já territorializada nas principais áreas produtoras, e nas vantagens oferecidas pelos governos locais como terrenos e incentivos fiscais (estado e municípios) têm atraído novas empresas interessadas nessa convergência de fatores. 
Apesar da reorganização produtiva em curso, a condição da produção industrial voltada para o mercado externo, mesmo da agroindústria, é discreta em Mato Grosso, já que a produção industrial destinada à exportação apresenta um decréscimo progressivo se comparado com a exportação de produtos básicos, como fica evidenciado na Tabela 3.

Tabela 3 - Exportações do estado de Mato Grosso de 1998 a 2014

\begin{tabular}{|c|c|c|c|c|c|c|c|c|}
\hline \multicolumn{9}{|c|}{ EXPORTAÇÃO BRASILEIRA - MATO GROSSO - Totais por Fator agregado - US\$ 1.000 FOB } \\
\hline Ano & Básicos & $\begin{array}{l}\% \text { do } \\
\text { total }\end{array}$ & Industrializados $(A+B)$ & $\begin{array}{l}\% \text { do } \\
\text { total }\end{array}$ & Semimanufaturados (A) & Manufaturados (B) & Op. especiais & TOTAL \\
\hline 1998 & 522.848 & 80 & 129.694 & 20 & 67.884 & 61.810 & 119 & 652.661 \\
\hline 1999 & 559.608 & 76 & 181.439 & 24 & 104.722 & 76.717 & 48 & 741.095 \\
\hline 2000 & 871.037 & 84 & 160.879 & 16 & 93.518 & 67.361 & 1.437 & 1.033 .354 \\
\hline 2001 & 1.222 .933 & 88 & 172.637 & 12 & 95.202 & 77.434 & 203 & 1.395 .772 \\
\hline 2002 & 1.535 .710 & 86 & 259.655 & 14 & 171.223 & 88.432 & 488 & 1.795 .853 \\
\hline 2003 & 1.817.346 & 83 & 368.816 & 17 & 264.925 & 103.892 & 1 & 2.186 .163 \\
\hline 2004 & 2.561 .596 & 83 & 540.293 & 17 & 381.800 & 158.493 & --- & 3.101 .889 \\
\hline 2005 & 3.477 .763 & 84 & 673.865 & 16 & 495.164 & 178.701 & --- & 4.151 .628 \\
\hline 2006 & 3.710 .325 & 86 & 623.141 & 14 & 367.362 & 255.779 & 2 & 4.333.468 \\
\hline 2007 & 4.382.154 & 85 & 748.708 & 15 & 426.708 & 321.999 & 5 & 5.130 .866 \\
\hline 2008 & 6.892 .697 & 88 & 919.649 & 12 & 643.951 & 275.698 & -- & 7.812 .346 \\
\hline 2009 & 7.711 .834 & 92 & 715.035 & 8 & 572.895 & 142.140 & --- & 8.426 .869 \\
\hline 2010 & 7.715.784 & 91 & 746.422 & 9 & 607.920 & 138.502 & 2 & 8.462 .207 \\
\hline 2011 & 10.240 .069 & 92 & 859.454 & 8 & 693.806 & 165.648 & --- & 11.099 .523 \\
\hline 2012 & 12.872 .156 & 93 & 992.803 & 7 & 791.186 & 201.617 & -- & 13.864 .959 \\
\hline 2013 & 14.903 .775 & 94 & 912.176 & 6 & 755.370 & 156.806 & -- & 15.815 .951 \\
\hline 2014 & 14.084.385 & 95 & 712.293 & 5 & 586.244 & 126.049 & 145 & 14.796 .823 \\
\hline
\end{tabular}

Fonte: Ministério do Desenvolvimento, Indústria e Comércio Exterior (MDIC)/SECEX, 2014

Organização: LIMA, Ronei Coelho de, 2015

Um exemplo da desaceleração do valor das exportações dos produtos industrializados em Mato Grosso, em decorrência da redução da demanda internacional, é que no comparativo dos anos de 2012 e 2013, o grupo de produtos composto por soja e milho passou de $57,47 \%$ para 64,30\% de participação no total exportado (de US\$ 7.967.219.189,00 para US\$ 10.185.346.114,00), apresentando um crescimento de 27,84\%. No mesmo período, porém, as exportações de bagaços e outros resíduos da soja tiveram uma redução de 6,22\%, variando de US\$2.190.320.814,00 em 2012 para US\$ 2.054.132.884,00 em 2013. O ano de 2014 apresenta uma pequena queda nos valores exportados do conjunto soja e milho para US\$ 9.262.668.241,00 (variação negativa de 9,1\%), enquanto a exportação de bagaço de soja foi reduzida para US\$1.897.203.558,00 (variação negativa de 7,6\%).

Esse cenário se dá mesmo havendo um ganho de preço da tonelada exportada de bagaço de soja que passou de US\$ 483,77 em 2012 para US\$ 530,17 em 2013 e para US\$ 
538,00 em 2014. A tendência de redução dos volumes exportados desse produto pode ser observada no Gráfico 1, em que temos uma comparação com as exportações de soja e milho do período de 2009 a 2014.

Gráfico 1 - Mato Grosso: Evolução da Exportação de Produtos Selecionados de 2009 a 2014

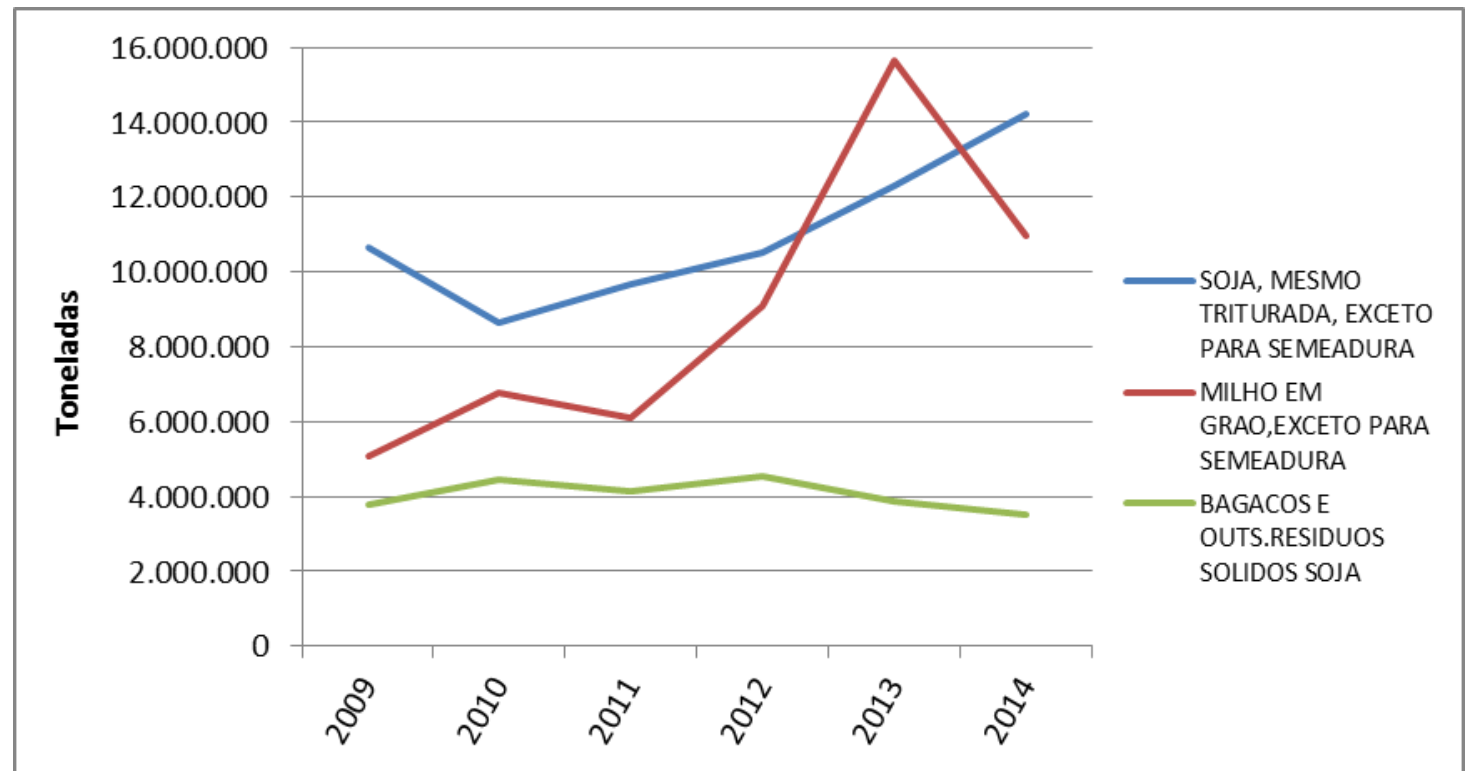

Fonte: MDIC, SECEX, Exportação brasileira: principais produtos exportados, 2009, 2010, 2011, 2012, 2013 e 2014 Organização: LIMA, Ronei Coelho de (2014)

A agroindústria, nesse cenário, reduz suas operações à espera de melhores preços e maior demanda, mas, como grande parte das tradings proprietárias das plantas de processamento são também as maiores exportadoras de grãos, não sofrem tanto o impacto, pois seguem as tendências do mercado e exportam os produtos mais vantajosos.

O reflexo dessa condição favorece os municípios cuja economia se baseia na produção de grãos, como é o caso de Sorriso, Nova Mutum, Lucas do Rio Verde; interfere menos em municípios como Cuiabá, que é sede de grandes exportadores como os grupos Amaggi e Bom Futuro, e impacta profundamente Rondonópolis. Esse município possui o segundo maior PIB do setor industrial de Mato Grosso e é a segunda economia do estado, porém sofre uma desaceleração devido a atual conjuntura já explicitada. Esse quadro está alinhado com uma tendência nacional de reprimarização das exportações brasileiras que as tornam mais frágeis. Sobre a dinâmica desse processo em curso que aumenta a vulnerabilidade das exportações brasileiras, com a crescente participação dos bens primários e de baixo valor agregado, Frederico (2013, p. 104), coloca que "Além da reprimarização houve também a concentração 
das exportações em poucos produtos, tornando a economia brasileira ainda mais dependente e vulnerável.".

É possível constatar esse fenômeno no Gráfico 2, composto pelos cinco maiores exportadores, que mostra a tendência de crescimento das exportações dos municípios produtores de soja e milho, como Sorriso, Nova Mutum e Lucas do Rio Verde, notadamente a partir de 2009, e de outro lado, um pico de Rondonópolis em 2005, com períodos subsequentes de oscilações recorrentes, até recuperar o maior patamar em 2014. A recuperação está atrelada, entre outros motivos, ao funcionamento do terminal ferroviário que conta com a planta processadora da Noble e porque o município continua estruturado como grande processador de grãos e de insumos nos últimos dez anos.

\section{Gráfico 2 - Evolução das exportações de municípios selecionados de Mato Grosso de 1997 a 2014}

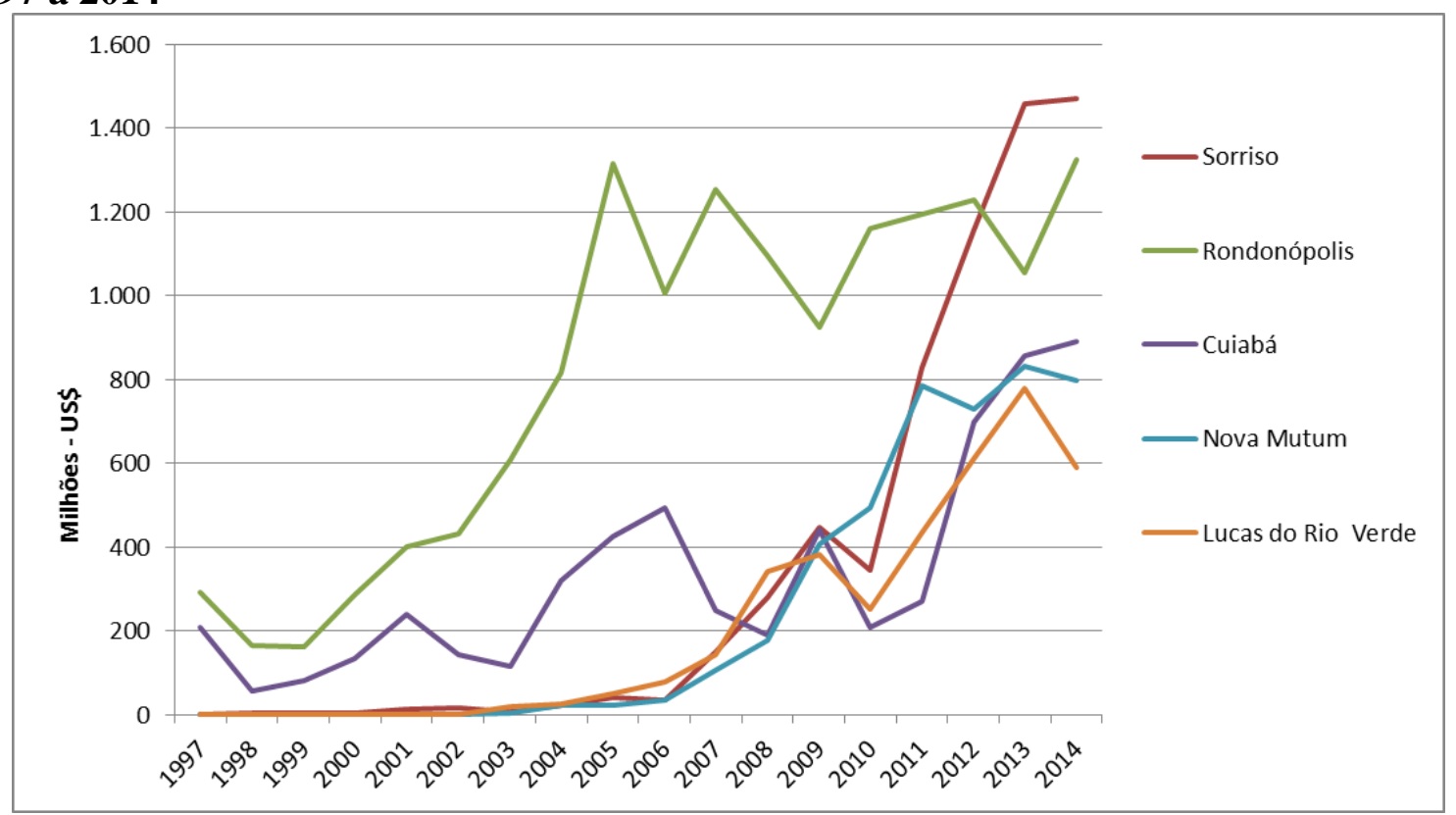

Fonte: MDIC, SECEX, Balança comercial brasileira por municípios (1997 a 2014)

Organização: LIMA, Ronei Coelho de (2014)

Os dois maiores exportadores de 2013 e 2014, Sorriso e Rondonópolis respectivamente, apresentam variações na pauta de exportações que revelam as suas diferenças quanto à estruturação do setor produtivo.

Em 2013, houve uma mudança na liderança das exportações em Mato Grosso, pois Sorriso passou a ser o maior exportador ao ultrapassar o município de Rondonópolis que liderava as exportações do estado. Na pauta das exportações de Sorriso naquele ano, 50\% foram de Soja, mesmo triturada, exceto para semeadura, que totalizaram US\$ 730.306.692,00, 
que se somaram aos $44 \%$ representado pelo Milho em grão, exceto para semeadura, com US\$ 638.830.007,00; já em 2014, a soja mesmo triturada representou 64\% das exportações com um total de US\$ 933.046.404,00, seguida do milho com 24\% totalizando US\$ $361.714 .383,00$.

Os dois produtos primários totalizam 94\% em 2013 e 84\% em 2014, das exportações do município e demonstram a relevância dos mesmos para a sua economia, visto não possuir plantas industriais para o processamento nos mesmos níveis de Rondonópolis e Cuiabá. Enquanto Rondonópolis concentra três grandes plantas processadoras (ADM, Bunge e Noble) e Cuiabá possui 5 plantas industriais ativas, conforme pode ser observado no Quadro 7, Sorriso tem instalada apenas as unidades da Caramuru e Bunge.

\section{Quadro 7 - Capacidade Instalada de Processamento de Oleaginosas em Mato Grosso em} 2013

\begin{tabular}{|l|l|l|l|c|c|}
\hline \multicolumn{1}{|c|}{ Empresa } & Localização da unidade & UF & $\begin{array}{c}\text { Processo } \\
\text { de Extração }\end{array}$ & $\begin{array}{c}\text { Oleaginosas } \\
\text { processadas }\end{array}$ & $\begin{array}{c}\text { Situação } \\
\text { da Unidade }\end{array}$ \\
\hline Agrenco & Alto Araguaia & MT & Solvente & Soja & Parada \\
Louis Dreyfus Commodities & Alto Araguaia & MT & Solvente & Soja & Ativa \\
Amaggi & Cuiabá & MT & Solvente & Soja & Ativa \\
Atlas & Cuiabá & MT & Solvente & Soja & Ativa \\
Clarion & Cuiabá & MT & Solvente & Soja & Parada \\
Grupal & Cuiabá & MT & Solvente & Soja & Parada \\
Ovelpar & Cuiabá & MT & Solvente & Soja & Ativa \\
Producampo & Cuiabá & MT & Solvente & Soja & Ativa \\
Sperafico & Cuiabá & MT & Solvente & Soja & Ativa \\
Amaggi & Lucas do Rio Verde & MT & Solvente & Soja & Ativa \\
Bunge & Nova Mutum & MT & Solvente & Soja & Ativa \\
Araguassú & Porto Alegre do Norte & MT & Solvente & Soja & Ativa \\
Cargill & Primavera do Leste & MT & Solvente & Soja & Ativa \\
ADM & Rondonópolis & MT & Solvente & Soja & Ativa \\
Bunge & Rondonópolis & MT & Solvente & Soja & Ativa \\
Bunge & Rondonópolis & MT & Prensa & Algodão & Ativa \\
Bunge & Sondonópolis & MT & Solvente & Soja & Ativa \\
Caramuru & Sorriso & Solvente & Soja & Ativa \\
\hline
\end{tabular}

Fontes: ABIOVE, 2014, BUNGE, 2014.

Os valores que levaram Sorriso à liderança das exportações estão relacionados aos preços mais elevados da soja e milho em grãos, diminuindo a diferença histórica para o farelo de soja, que em 2013 não teve um bom desempenho, mas que obteve leve recuperação em 2014. 
De outro lado, 63\% das exportações de Rondonópolis no ano de 2013, que totalizaram US\$ 662.111.664,00, foram de bagaços e outros resíduos sólidos da extração do óleo de soja; em 2014, esse produto representou 57\% das exportações do município, com um total de US\$ 748.080.114,00. Esse tipo de produto demanda o processamento da soja e, mesmo possuindo um maior valor agregado, passou a ter o seu preço em relação ao grão exportado nos seus níveis mais baixos, impactando negativamente as exportações dessa commodity pelo município.

Quanto às importações, o cenário mato-grossense se inverte, pois somente $12 \%$ dos produtos importados em 2014 eram básicos, ante a $88 \%$ de produtos industrializados.

No que tange às importações, Rondonópolis não encontra paralelo em Mato Grosso, pois o município concentra grande parte das plantas industriais de fertilizantes e, como os insumos são importados, apresenta uma maior densidade nesse quesito. Do total das importações de Mato Grosso em 2014, Rondonópolis concentra 47\%, seguido por Cuiabá com $26 \%$ e Alto Araguaia com $12 \%$. Em conjunto esses três municípios respondem por $85 \%$ do total de importações de Mato Grosso, caracterizando uma concentração acentuada desse setor.

A situação de Alto Araguaia assemelha-se à de Rondonópolis, pois em virtude da instalação do terminal ferroviário da ALL, empresas do ramo de fertilizantes se instalaram no município, fazendo-o figurar entre os maiores importadores. Já a capital Cuiabá tem nas importações de gás de petróleo e outros hidrocarbonetos gasosos seu principal item na pauta de importações com um total de $43 \%$.

Na Tabela 4, podemos observar a evolução das importações mato-grossense nos últimos dezessete anos, enquanto o Gráfico 3, evidencia que o estado de Mato Grosso é superavitário na balança comercial, pois a diferença dos valores das exportações e das importações é bem acentuada e não apresenta, atualmente, uma aproximação. Este cenário colabora diretamente com o saldo comercial brasileiro que passa cada vez mais a depender do agronegócio para equilibrar sua conta corrente. 
Tabela 4 - Importações do estado de Mato Grosso de 1998 a 2014

\begin{tabular}{|c|c|c|c|c|c|c|c|c|}
\hline \multicolumn{9}{|c|}{ IMPORTAÇÃO BRASILEIRA - MATO GROSSO - Totais por Fator agregado - US\$1.000 FOB } \\
\hline Ano & Básicos & $\begin{array}{l}\% \text { do } \\
\text { total }\end{array}$ & Industrializados $(\mathrm{A}+\mathrm{B})$ & $\begin{array}{l}\% \text { do } \\
\text { total }\end{array}$ & Semimanufaturados (A) & Manufaturados (B) & Op. especiais & TOTAL \\
\hline 1998 & 3.798 & 5 & 80.199 & 95 & 3.165 & 77.034 & --- & 83.997 \\
\hline 1999 & 9.711 & 6 & 139.970 & 94 & 4.822 & 135.148 & --- & 149.681 \\
\hline 2000 & 2.052 & 2 & 88.593 & 98 & 20.868 & 67.725 & --- & 90.644 \\
\hline 2001 & 3.828 & 3 & 132.704 & 97 & 33.966 & 98.737 & --- & 136.532 \\
\hline 2002 & 53.684 & 26 & 155.365 & 74 & 68.215 & 87.150 & -- & 209.049 \\
\hline 2003 & 62.064 & 22 & 214.625 & 78 & 72.070 & 142.554 & --- & 276.688 \\
\hline 2004 & 24.440 & 6 & 393.240 & 94 & 154.303 & 238.936 & --- & 417.680 \\
\hline 2005 & 22.207 & 5 & 387.992 & 95 & 182.277 & 205.715 & --- & 410.199 \\
\hline 2006 & 19.398 & 5 & 387.120 & 95 & 165.758 & 221.363 & --- & 406.518 \\
\hline 2007 & 23.959 & 3 & 729.326 & 97 & 265.449 & 463.878 & --- & 753.285 \\
\hline 2008 & 30.086 & 2 & 1.247 .090 & 98 & 531.815 & 715.275 & --- & 1.277 .176 \\
\hline 2009 & 8.451 & 1 & 783.945 & 99 & 463.323 & 320.621 & -- & 792.396 \\
\hline 2010 & 6.014 & 1 & 982.966 & 99 & 497.189 & 485.777 & --- & 988.980 \\
\hline 2011 & 10.701 & 1 & 1.567 .782 & 99 & 641.538 & 926.243 & --- & 1.578 .483 \\
\hline 2012 & 108.241 & 7 & 1.470 .248 & 93 & 673.625 & 796.623 & --- & 1.578 .488 \\
\hline 2013 & 184.960 & 11 & 1.520 .171 & 89 & 595.964 & 924.207 & --- & 1.705 .131 \\
\hline 2014 & 213.337 & 12 & 1.554 .868 & 88 & 560.353 & 994.515 & --- & 1.768 .205 \\
\hline
\end{tabular}

Fonte: Ministério do Desenvolvimento, Indústria e Comércio Exterior (MDIC)/SECEX, 2014

\section{Gráfico 3 - Saldo comercial de Mato Grosso no período de 1998-2014}

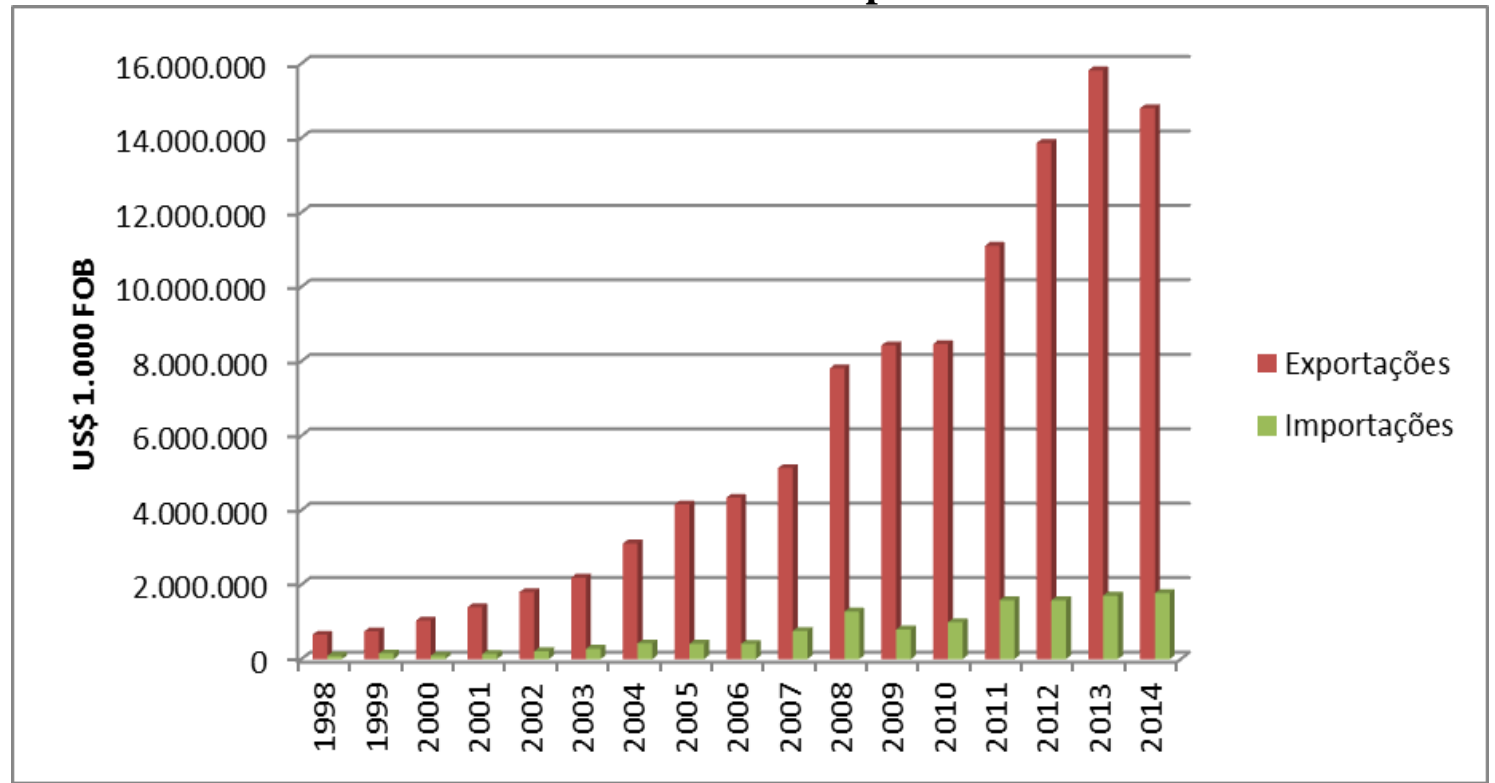

Fonte: Ministério do Desenvolvimento, Indústria e Comércio Exterior (MDIC)/Secex, 2014 Organização: LIMA, Ronei Coelho de (2014)

O discurso de que o agronegócio brasileiro é um setor altamente produtivo, eficiente e importante para a economia nacional cria um imaginário de crescimento econômico pleno e de desenvolvimento social. A mídia apresenta as principais cidades como oásis de progresso e terras de oportunidades, com isso temos um traço de positividade em consonância com o 
moderno e o racional. A realidade, todavia, revela-se de forma mais complexa, com elementos de desigualdade social e de concentração de renda, logo os conflitos sociais também estão presentes.

Mas, assim como os processos mais complexos de produção podem alienar as pessoas, também as regiões podem ser alienadas quanto à sua participação em uma engrenagem cujo conteúdo não é de todo sabido, mas que objetiva a produção de valor, pois como assinala Seabra (2009, p. 433) “A generalização do valor alcançou os mais recônditos lugares, provocou expropriações, produziu alienações dando em troca o mundo da mercadoria."

Nesse sentido, Santos (2008a, p. 227) enfatiza que como todos os dias o mundo está criando uma novidade,

[...] cada dia somos ignorantes do que são e do que valem as coisas novas. Essa criação cotidiana do homem ignorante também leva regiões inteiras a ignorar o que elas são, sempre que não conhecem os segredos do funcionamento dos respectivos objetos e ações. Quanto menos dominam esses segredos, têm menos condições de comandar a sua própria evolução e mais dirigidas de fora tendem a ser. [...] Nunca, como agora, houve tanta necessidade de um saber competente, para reinterpretar a lição dos objetos que nos cercam e das ações de que não podemos escapar.

É nesse contexto que o espaço mato-grossense é produzido, em sintonia com o movimento capitaneado pelos agentes econômicos hegemônicos e com o apoio do Estado que busca oferecer as condições exigidas pelos setores ligados ao agronegócio.

Não é de estranhar as disputas efetuadas pelos municípios, cada um tentado oferecer mais vantagens, inclusive abrindo mão da arrecadação por meio dos incentivos fiscais que são oferecidos em vários níveis, notadamente pelos estados e municípios. Mas as vantagens disponibilizadas pelas empresas, como as vagas de empregos, podem apresentar resultados pouco satisfatórios, pois o número de empregos oferecidos tende a cair em virtude do aumento da densidade técnica das unidades produtivas. Com isso, é necessário que mais empresas se instalem, criando um círculo que está longe de criar um desenvolvimento social sustentado.

Mas, na dinâmica dos processos que permeiam a produção mato-grossense, a intensificação dos fluxos (de capitais, de mercadorias, pessoas e informações) demanda um 
novo arranjo na fluidez territorial no bojo da formação dos circuitos espaciais da produção. Esse fenômeno não é exclusivo dessa porção do território, mas conforma-se como uma realidade nacional.

Em estudo sobre o território brasileiro e a sua relação recente com o mercado externo, Arroyo (2003) discute a internacionalização do capital argumentando que os fluxos de mercadorias e os fluxos de capitais de investimentos diretos e de aplicações financeiras encontram certa porosidade e fluidez territorial. Para a autora, principalmente os fluxos de mercadorias se beneficiam da modernização dos fixos, efetuadas nas rodovias, ferrovias, hidrovias e nos portos e aeroportos. Com essa complexificação da dinâmica de circulação, a logística surge como importante ramo de serviços.

Inclusive as transformações contidas na formação dos fluxos, que ocorrem em diversas escalas, se mostram estruturais na medida em que influenciam o setor econômico de forma mais profunda. Nesse sentido, Hesse e Rodrigue (2004) argumentam que os crescentes fluxos de mercadorias se tornam fundamentais nas mudanças atuais que ocorrem nos sistemas econômicos e perpassam as escalas global, regional e local. Entendem que essas mudanças devem ser observadas sob uma perspectiva de caráter estrutural e operacional, muito além de um conteúdo meramente quantitativo.

Da mesma forma, a complexificação dos fluxos demanda a criação de um conjunto de normas institucionais, como os recintos aduaneiros e alfandegários que são favorecedores da fluidez corporativa. No conjunto dessas condições temos a abertura do território e assim:

[...] os circuitos espaciais de produção vinculados ao mercado externo usufruem diretamente dessa situação, já que os círculos de cooperação a eles associados são a expressão das novas qualidades e quantidades que assumem a fluidez e a porosidade territorial. [...] Ao mesmo tempo, a tendência crescente à concentração econômica experimentada por esses circuitos são, desse modo, portadores de uma hierarquia territorial. (ARROYO, 2003, p. 429).

A realidade mato-grossense reflete essa condição, pois como em qualquer hierarquia, os estratos mais baixos sofrem com a falta dos fixos modernos favorecedores de uma maior fluidez, como é o caso da maior parte do território que não possui as condições adequadas e nem os meios dinamizadores do movimento corporativo. Essa condição, inclusive, se estende 
às áreas pujantes da produção agropecuária, o que caracteriza a incompletude do projeto nacional e corporativo de integração do território.

As áreas com as condições mais favoráveis no momento estão localizadas nas proximidades da capital Cuiabá, e principalmente na parte Sul do estado na área de influência de Rondonópolis, onde temos dois modais em funcionamento. A fluidez territorial nessa última área é efetuada pela intermodalidade entre as vias rodoviária (BR-163, BR-364, MT130, MT-270) e ferroviária (ALLMN).

Aqui o termo intermodalidade é concebido como um processo de transporte de cargas efetuado a partir de um sistema de redes que são interconectadas e que envolvem diversas combinações de modais de transportes, com as partes componentes possuindo vínculos perfeitos e coordenação eficiente, conforme apontam Rondinelli e Berry (2000) com base nos preceitos de Boske (1998). Para os autores, esse processo sistematizado oferece um conjunto importante de modos de transportes e opções de roteamento aos clientes, permitindo-lhes coordenar diversas etapas, como a oferta, a produção, o armazenamento, as finanças e as demais funções de distribuição que resultam no alcance de relações mais eficientes.

Por isso os diversos setores do agronegócio demandam investimentos no sistema de transportes, pois visam adequá-lo às suas necessidades de fluidez para garantir os prazos de entrega. Outro ponto importante é a manutenção dos fluxos com a possibilidade de crescimento dos mesmos, já que a escala de produção é elemento nodal na produção de commodities, principalmente em Mato Grosso, em decorrência das grandes distâncias dos terminais portuários, o que implica na necessidade de otimização dos custos com transportes.

No entanto, a realidade quanto às rodovias disponíveis, mesmo na região de Rondonópolis que é mais articulada, é que essas apresentam condições apenas razoáveis de trafegabilidade e não comportam atualmente os fluxos existentes (excetuando-se a rodovia estadual MT-270, cuja intensidade de fluxo é menor). Já o modal ferroviário não apresenta vantagens financeiras aos consumidores do serviço de transportes, pois por não enfrentar concorrência não dispõe de preços competitivos do frete até os terminais de desembarque. A relutância por parte da ALL em revelar o valor cobrado por tonelada transportada das tradings, que repassam os custos para os produtores, é um exemplo de como as relações entre empresas torna-se pertencente a um circuito particular do meio corporativo, com certas informações não disponibilizadas para a sociedade, por tratar-se, como argumenta Márcio Martines (gerente do terminal da ALL em Rondonópolis) de informação estritamente 
comercial, sendo tratada diretamente pelas empresas envolvidas. Além disso, o modal ferroviário que atende a produção mato-grossense enfrenta problemas de tráfego no estado de São Paulo por conta dos congestionamentos na ferrovia no trecho paulista e no porto de Santos.

Outros elementos que caracterizam a superioridade da fluidez territorial é a presença do porto seco de Mato Grosso em Cuiabá e do Recinto Especial para Despacho Aduaneiro de Exportação (REDEX) em Rondonópolis - sendo esse recinto operado pela empresa Brado Logística S.A -, que podem ser visualizados nas Figuras 4 e 5.

\section{Figura 4 - Instalações do Porto Seco em Cuiabá-MT}

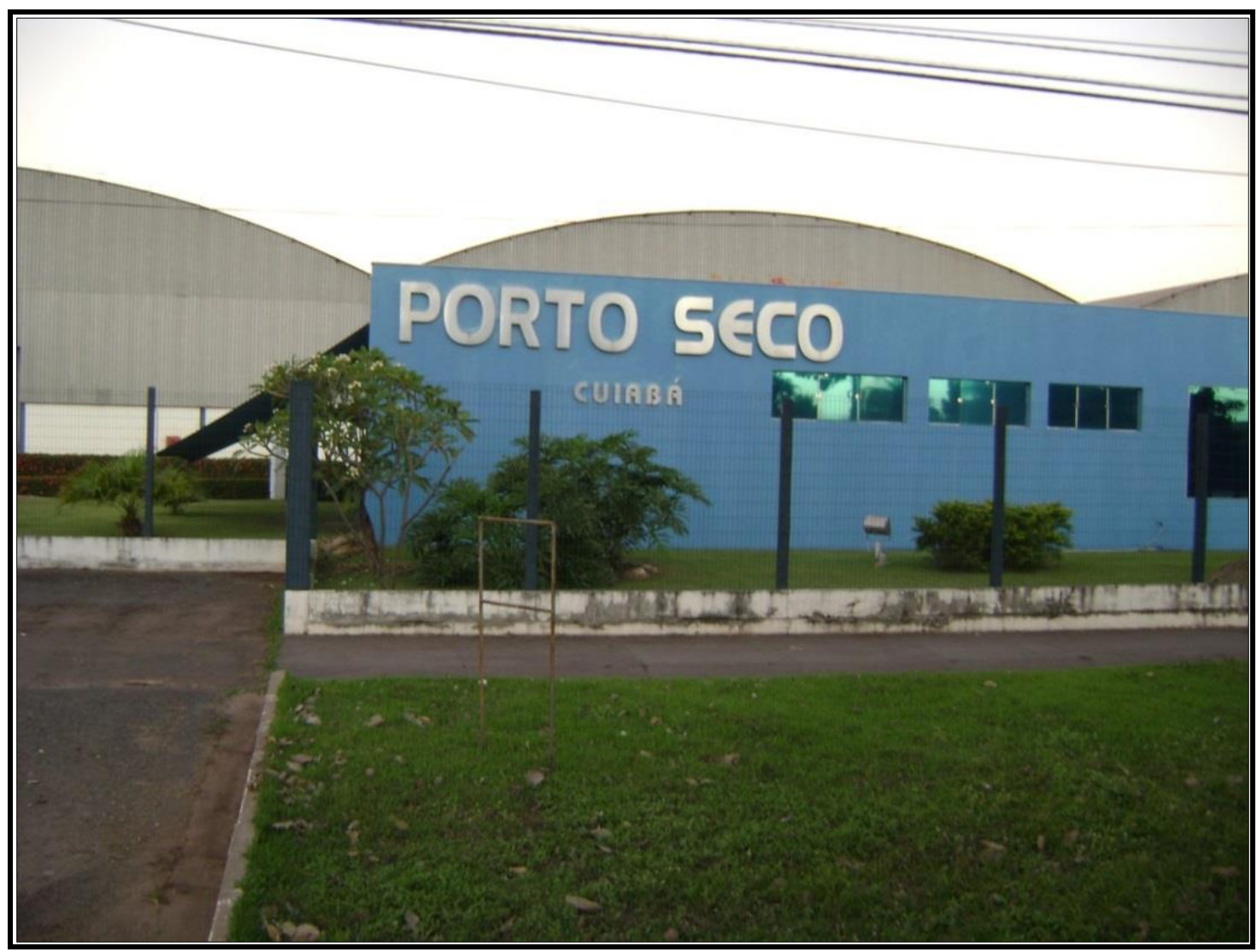

Fonte: LIMA, Ronei Coelho de (2014) - Trabalho de campo realizado em 04 de maio de 2014. 


\section{Figura 5 - Instalações da Redex (Brado Logística) em Rondonópolis}

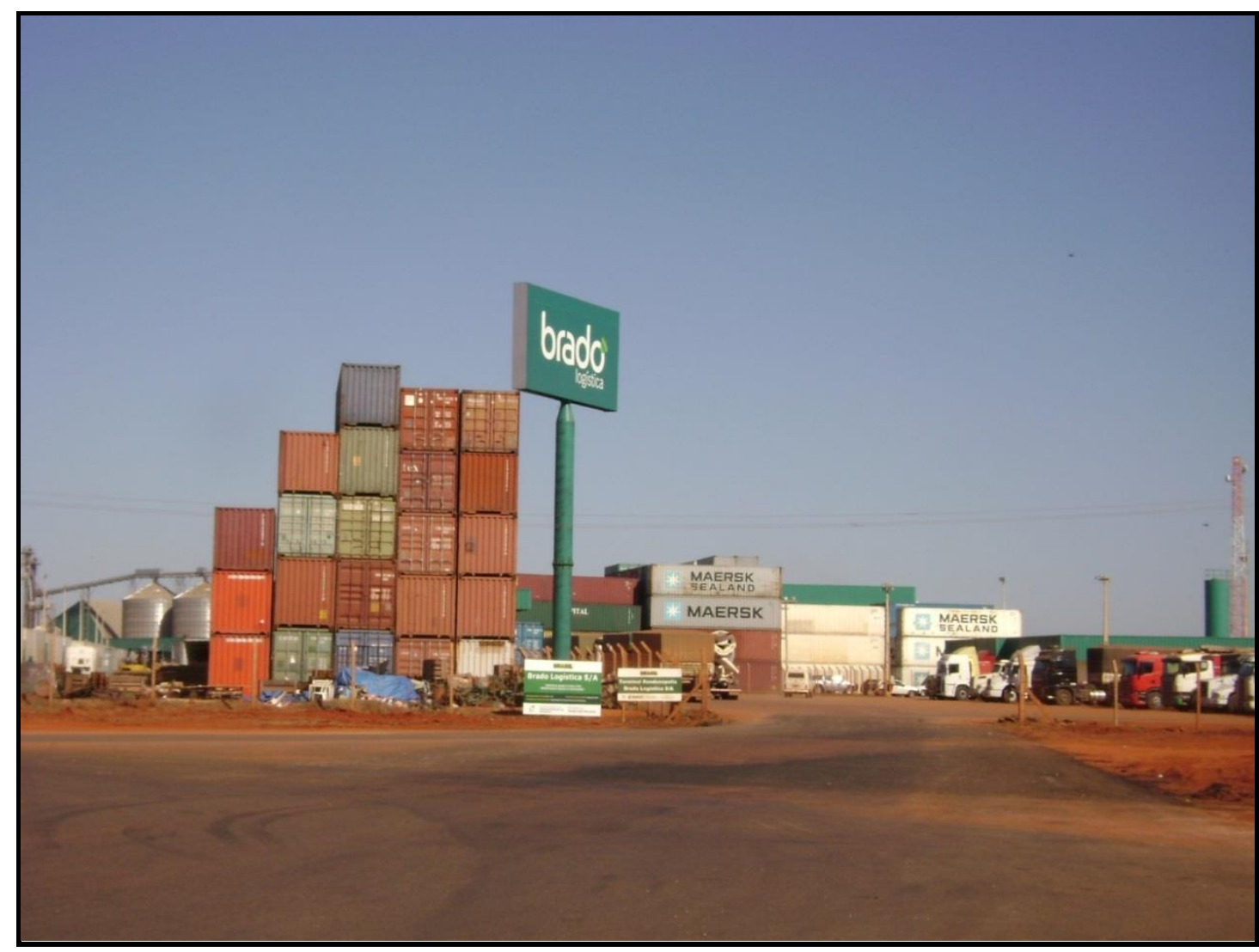

Fonte: LIMA, Ronei Coelho de (2014) - Trabalho de campo realizado em 02 de julho de 2014

Diante da existência de uma hierarquia territorial, a condição dos fluxos também apresenta certa hierarquia, pois como temos defendido, o uso corporativo do território privilegia a produção extrovertida e dessa forma induz o Estado à criação das infraestruturas voltadas a essa produção, pois a ampliação do mercado demanda melhores condições de articulação.

Assim, a ideia de corredores de exportação resiste ao tempo e se materializa nas principais rodovias, ferrovias e hidrovias existentes ou projetadas. Esses sistemas de engenharia de transportes florescem no âmbito dos discursos de positividade inerentes ao desenvolvimento via gestão territorial.

Nesse contexto, cabe analisarmos as condições da logística dirigida para a produção existente, com ênfase para a realidade das rodovias, ferrovias e sistemas de armazenagem frente às demandas extrovertidas do mercado - no contexto do espaço nacional da economia internacional (SANTOS, 2008, p. 243) -, pois se evidencia a concentração econômica dos 
circuitos espaciais da produção e círculos de cooperação vinculados às grandes corporações, principalmente internacionais, cujos rebatimentos reestruturam a dinâmica territorial. Nesse sentido concordamos com Becker (2007, p. 268) quando argumenta que “[...] a logística, hoje inerente à geopolítica e visando à inserção competitiva na globalização - é um vetor fundamental na reestruturação, constituindo a ossatura do território [...]”. Cabe ao Estado, ao exercer seu poder sobre o território, definir as prioridades, quanto à sua circulação, tomando a precaução de não focar apenas em um conjunto de interesses corporativos em detrimento de atender a interesses sociais mais amplos.

\subsection{A LOGÍSTICA DE TRANSPORTES INSTALADA: O MODAL RODOVIÁRIO}

A logística parece ser onipresente quando se trata da competitividade almejada pelos setores produtivos e, principalmente, pelos grupos vinculados ao agronegócio, pois como a escala de produção cresce continuamente, exige-se uma perfeita sincronia de diversos setores que permitam a circulação das mercadorias até o consumidor final.

Das áreas mais estruturadas, como a Região Concentrada (SANTOS; SILVEIRA, 2004), àquelas com precárias condições, como o Centro-Oeste, principalmente o estado de Mato Grosso, as estratégias adotadas demandam a utilização da logística, sendo essa entendida como um conjunto complexo de ações que exigem objetos técnicos específicos que permitam o controle das condições dos diversos fluxos, notadamente os de mercadorias. Daí a necessidade da existência de sistemas de transportes, de armazenagem e de informação integrados que favoreçam a otimização dos processos efetivados.

A estruturação da circulação da produção nas áreas de Cerrado não apresenta uma adequação aos fluxos materiais produzidos, como no caso das rodovias de Mato Grosso (CNI; CNA; MACROLOGÍSTICA, 2013) que apresentam sobrecargas elevadas.

Com isso são necessários investimentos de diversas origens, principalmente os públicos, privados e híbridos, para a criação da logística necessária para a movimentação da produção.

Adjetivando de moderna a logística, Castillo (2008, p. 405) aponta que: 
A logística moderna pode ser designada como o conjunto de competências infra-estruturais (transportes, comunicações, armazéns terminais etc.), normativas (regulações, impostos, aduanas, acordos comerciais, agências setoriais etc.) e operacionais que, reunidas num subespaço, conferem competitividade aos circuitos produtivos e aos agentes que dele fazem parte.

O autor ainda argumenta que sendo entendida como elemento da circulação corporativa hoje em curso, a logística moderna favorece a racionalização e otimização, nos diversos territórios, da sincronização de diversas técnicas (desde as mais avançadas àquelas em estágio menos desenvolvido) o que permite a interligação dos espaços produtivos mais competitivos com os principais centros de consumo.

Nesse sentido, Silveira (2011a, p. 22), ao discutir a questão da logística, sustenta que foi "[...] na década de 1980 que a logística assume papel fundamental e se consolida como serviço superior que objetiva majoritariamente o atendimento das demandas corporativas ("logística corporativa")". O autor aponta que a estruturação da logística corporativa se dá com a necessidade de redução de custos das corporações, as quais elevam a um novo patamar as estratégias de planejamento e gestão de transportes e de armazenamento.

Esse cenário está bem adequado à sua temporalidade, pois a década de 1980 conhecida como a década perdida, devido às consequências das crises iniciadas na década de 1970 e prolongada pela seguinte -, passou a exigir novas dinâmicas dos setores produtivos na busca por maior racionalidade dos custos e sua consequente redução, pois são configuradas alterações no regime de acumulação que se estrutura de forma mais flexível.

Como a logística - entendida enquanto estratégia, planejamento e gestão -, possui estreito vínculo com o processo de circulação (transportes, armazenamento e comunicação), esta se torna imprescindível para a realização da totalidade do processo e por isso emerge no mundo corporativo e no Estado com demasiada importância.

No caso brasileiro, como o Estado priorizou o modal rodoviário, esse passa a ser alvo das ações logísticas em busca de uma maior integração entre modais, carecendo assim de maior flexibilidade das operações de movimento de cargas. Dessa forma, considerando como mais racional os atributos intermodais, pela otimização dos recursos disponíveis e pela redução dos custos, busca-se integrar as rodovias aos demais modais para facilitar o movimento de mercadorias. 
Os sistemas de engenharia que são criados permitem uma aceleração da dinâmica dos transportes a partir da evolução contínua desses sistemas, porém a realização plena do processo de aceleração depende das condições de infraestruturas adequadas, bem como do sistema regulador. Quanto à primeira condição temos em Santos (2012, p. 90), a seguinte consideração:

Quanto mais evoluem os sistemas de engenharia, mais coisas se produzem ao mesmo tempo. Também se transportam mais objetos em menos tempo, o consumo se faz mais imediatamente, tornando tudo isso mais e mais fácil, graças aos equipamentos criados pelo Estado para facilitar a circulação.

Essa velocidade quando aplicada ao setor de transportes pode ser ampliada, mas é importante que possamos relativizá-la, na medida em que a questão dos custos nesse setor é elemento nodal, portanto não é possível trabalharmos com foco somente na velocidade do movimento de mercadorias. Pois, de uma forma geral, essa velocidade maior cabe mais a produtos cujo valor agregado permite um maior custo de transportes.

Nesse caso o transporte aéreo, cujo custo é o mais elevado, direciona-se para certo grupo de produtos; já para o transporte das commodities agrícolas, que é nosso objeto de análise, uma menor velocidade associada a um menor custo é extremamente racional. Assim, o conjunto menor velocidade/menor custo dos modais hidroviário, ferroviário e rodoviário (nessa ordem) se adequam às necessidades do setor produtivo do agronegócio.

A importância da circulação na viabilização do processo produtivo pode ser vislumbrada na consideração de Santos e Silveira (2004, p. 64) quando discutem a questão das rodovias, ferrovias e hidrovias no Brasil e, sobre as primeiras, fazem a seguinte consideração:

A trama dos sistemas de engenharia perfaz-se com a construção de rodovias modernas. Se outrora havia a necessidade de implantar sistema de objetos que assegurassem a produção e, por conseguinte, seu escoamento para o estrangeiro, hoje os sistemas de engenharia devem garantir primeiro a circulação fluida dos produtos, para possibilitar a produção em escala comercial. É a circulação, em sentido amplo, que viabiliza a criação e a continuidade das áreas de produção. 
Esse fenômeno ocorre no território mato-grossense, pois a produção agropecuária, principalmente a produção de grãos, ampliou-se horizontalmente, pela incorporação sistemática de áreas agricultáveis, e verticalmente, pelo aumento da produtividade em virtude da incorporação de técnicas modernas ao processo produtivo.

A confluência desses dois elementos passa a demandar um acréscimo constante de novos sistemas de engenharia, notadamente de armazéns e vias de transporte, para permitir a manutenção viável do processo produtivo. Porém, tanto um como o outro são insuficientes para atender a escala de produção atual, ocasionando grande pressão sobre os sistemas de engenharia existentes.

A região do Médio-Norte mato-grossense, área que concentra grande parte da produção de grãos do estado, não possui as condições ideais para fazer fluir sua produção, pois depende exclusivamente do modal rodoviário, cuja principal via é a BR-163, mostrada na Figura 6, no trecho em que coincide com a BR-364, que só agora está recebendo melhorias (duplicação entre Sinop até a divisa com Mato Grosso do Sul - mas com a cobrança de pedágio), para se adequar às necessidades logísticas do setor produtivo.

\section{Figura 6 - Rodovia BR-163/BR-364 no município de Diamantino-MT}

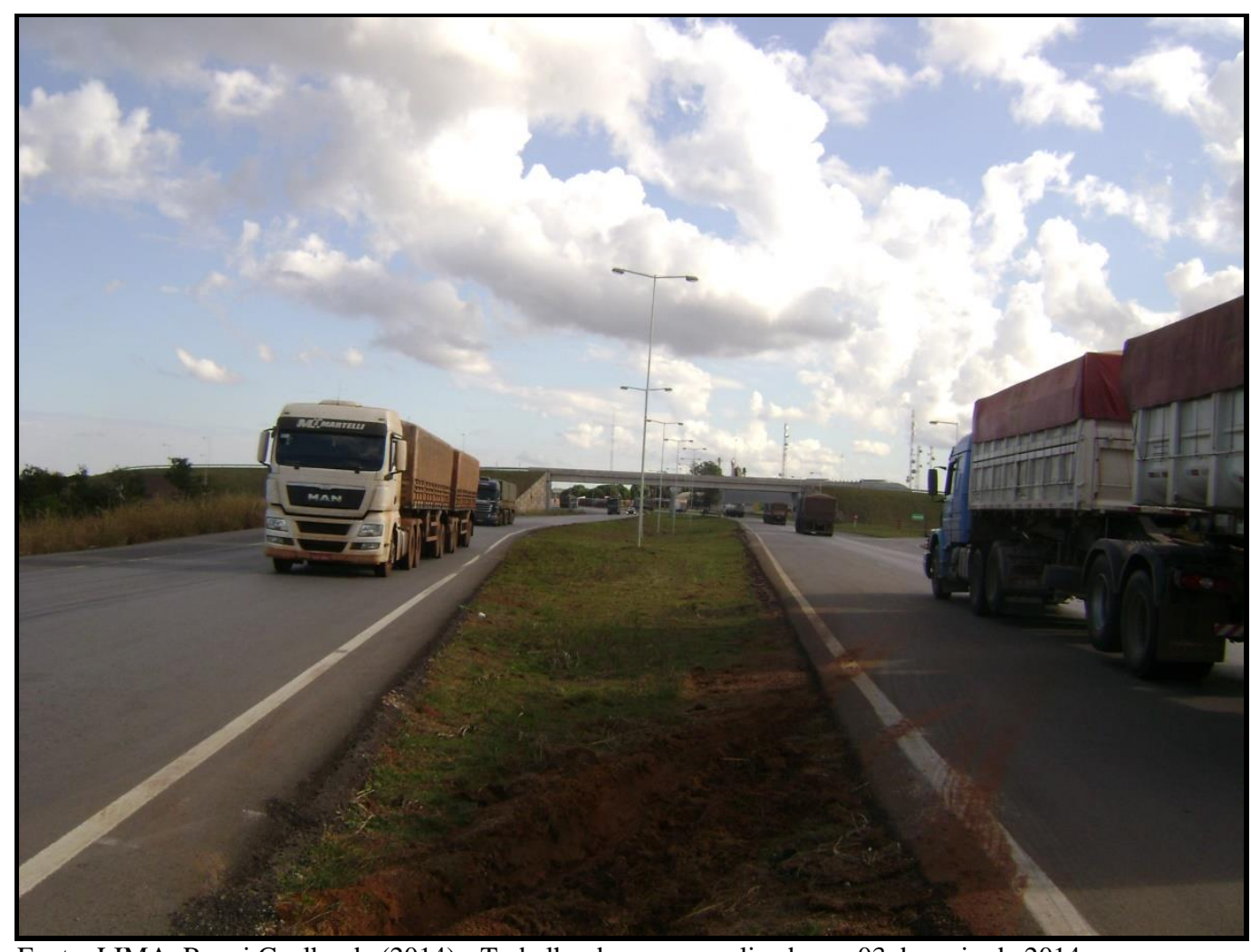

Fonte: LIMA, Ronei Coelho de (2014) - Trabalho de campo realizado em 03 de maio de 2014 
Por ser uma rodovia antiga, construída na década de 1970 e que recebeu poucas melhorias até então, apresenta-se em condições precárias não sendo suficientemente adequada ao fluxo que nela transita.

Iniciada pelo governo federal uma revitalização dessa rodovia, com a duplicação de vários trechos entre Rondonópolis e o Posto Gil, localizado no município de Diamantino, as ações de adequação da rodovia à realidade produtiva será gerida pela iniciativa privada, pois a mesma foi concedida pelo Estado e terá a cobrança de pedágio em seu percurso.

Essa estratégia de concessões das vias de escoamento - seja de ferrovias, rodovias ou terminais portuários, surge como alternativa para sanar a incapacidade do Estado de manter e aumentar os sistemas de engenharia de transportes, pois o aumento da demanda não foi alcançado pela iniciativa pública, logo essa se associa de formas diversas com o agente privado na busca pela melhoria das condições de fluidez necessárias ao processo produtivo de caráter extrovertido.

Quanto às condições de armazenamento da produção, essa também se mostra insuficiente para atender a demanda, notadamente da produção de grãos que exige condições técnicas de controle de qualidade bem rigorosas, pois devem atender às exigências dos padrões internacionais. Nesse sentido, evidencia-se também que parte considerável da estrutura armazenadora pertence às tradings que efetuam a originação de grãos em Mato Grosso, pois, como constata Becker (2007, p. 283) “A distribuição de silos e graneleiros serve para revelar a logística das grandes empresas dos complexos agroindustriais inseridos na economia globalizada".

A Tabela 5, apresenta as condições de armazenagem estática que atende parte do setor produtivo mato-grossense e demonstra a insuficiência desse setor fundamental.

A falta de armazéns implica na fragilização das estratégias, do planejamento e da gestão efetivados pelos produtores, pois concorre para a aceleração da movimentação de cargas, prejudicando o tempo hábil para negociações mais vantajosas para o setor. Dessa forma, a logística de transporte fica comprometida, já que a intensidade de aumento dos fluxos materiais ocorre de forma simultânea, provocando impedimentos à fluidez necessária. 
Tabela 5 - Capacidade estática de armazenagem de municípios selecionados de Mato Grosso em 2014

\begin{tabular}{lrrrrrrrr}
\hline \multicolumn{1}{c}{ Município } & \multicolumn{2}{c}{ Convencional } & \multicolumn{2}{c}{ Granel } & \multicolumn{2}{c}{ Total } & $\%$ \\
& Qtde & Capacidade (t) & Qtde & Capacidade (t) & Qtde & Capacidade (t) & MT \\
Sorriso & 20 & 111.163 & 192 & 3.622 .953 & 212 & 3.734 .116 & 12,6 \\
Primavera do Leste & 26 & 109.379 & 123 & 2.226 .475 & 149 & 2.335 .854 & 7,9 \\
Campo Novo do Parecis & 30 & 102.639 & 85 & 1.650 .231 & 115 & 1.752 .870 & 5,9 \\
Sapezal & 27 & 81.484 & 84 & 1.567 .480 & 111 & 1.648 .964 & 5,6 \\
Lucas do Rio Verde & 16 & 102.904 & 70 & 1.487 .675 & 86 & 1.590 .579 & 5,4 \\
Nova Mutum & 15 & 52.792 & 80 & 1.362 .274 & 95 & 1.415 .066 & 4,8 \\
Sinop & - & - & 49 & 1.336 .496 & 49 & 1.336 .496 & 4,5 \\
Rondonópolis & 31 & 219.682 & 54 & 975.641 & 85 & 1.195 .323 & 4,0 \\
Diamantino & 15 & 80.617 & 81 & 928.481 & 96 & 1.009 .098 & 3,4 \\
Campo Verde & 24 & 108.557 & 73 & 859.858 & 97 & 968.415 & 3,3 \\
\hline Total do grupo & 204 & 969.217 & 891 & 16.017 .564 & 1.095 & 16.986 .781 & $\mathbf{5 7 , 4}$ \\
\hline Mato Grosso & 456 & 2.201 .093 & 1.715 & 27.388 .209 & 2.171 & 29.589 .302 & 100 \\
\hline Fon & & & & & & &
\end{tabular}

Fonte: Conab, 2014

Org. LIMA, Ronei C. de (2014)

Assim, para uma produção estadual em 2013 de 46.766 .287 de toneladas das principais culturas de grãos (soja, milho, arroz, sorgo, feijão e girassol) e de algodão, de acordo com dados para 2013, do Levantamento Sistemático da Produção Agrícola do IBGE (IBGE, 2014a), Mato Grosso possui uma capacidade estática de armazenagem de 29.589.302 toneladas, ou seja, atende a $67 \%$ do que é produzido, originando um déficit de $33 \%$. Mas, se balizarmos a atual capacidade de armazenagem do estado de acordo com os padrões recomendados pela Food and Agriculture Organization of the United Nations (FAO), conforme aponta Gallardo et. al (2010) que é de 1,2 vezes (120\%) da produção, o déficit cresceria para $53 \%$.

Mesmo sabendo que todos os itens elencados não são colhidos e armazenados de forma simultânea, até porque ocorre a rotatividade de algumas culturas, como no caso da soja e do milho, a demanda reprimida de armazéns implica na necessidade de alta rotatividade dos produtos nos recintos armazenadores.

Como exemplo, é frequente nas áreas de maior produção, como em Lucas do Rio Verde e Sorriso, a retirada nos silos armazenadores do milho para dar lugar à soja, ficando aquele à mercê das intempéries até que seja negociado e transportado. 
Uma estratégia a ser tentada é a associação entre os produtores em forma de cooperativas, principalmente daqueles menos capitalizados, na construção de armazéns e silos a partir de linhas de créditos específicas para este fim que são disponibilizadas pelo governo federal por meio do Banco do Brasil.

Mas, segundo Caetano (2013), é preciso quebrar a resistência dos produtores nesse tipo de associação, pois as vantagens de ter controle sobre o armazenamento da produção é imprescindível para a competitividade do produtor. Já que, ao utilizar o armazém de uma trading para depositar os grãos, há um custo de estocagem embutido constituindo o chamado preço de balcão.

No entanto, sendo proprietário da estrutura armazenadora, pratica-se o preço do mercado disponível, com vantagem para o produtor.

A estrutura de armazenamento encontra-se espacializada nos principais municípios produtores de grãos e algodão, conforme pode ser observado no Mapa 4, que são servidos pelas principais vias de escoamento do estado.

Se excetuarmos Rondonópolis, que ocupa a $8^{\mathrm{a}}$ posição entre os dez municípios de maior capacidade de armazenagem estática e não é um grande produtor - o que pode ser explicado por esse município polarizar a primeira região produtora e concentrar as principais agroindústrias esmagadoras do estado -, os demais municípios, assim como Rondonópolis, se encontram distribuídos nas imediações das principais rodovias federais, o que otimiza a movimentação da produção.

Essa condição apenas reflete a questão da concentração econômica e centralidade de comando que esses municípios possuem, já que os custos de construção das unidades de armazenagem são elevados, selecionando, assim, os principais produtores dentre os demais. Temos então, nesse contexto, uma relação intensa entre os fluxos da produção das áreas de cultivo para os armazéns e desses para os principais troncos rodoviários. Antes, porém, a produção necessita circular por estradas vicinais que dificultam, principalmente no período chuvoso, a trafegabilidade dos veículos. 
Mapa 4 - Capacidade de Armazenagem Estática de Mato Grosso em 2014

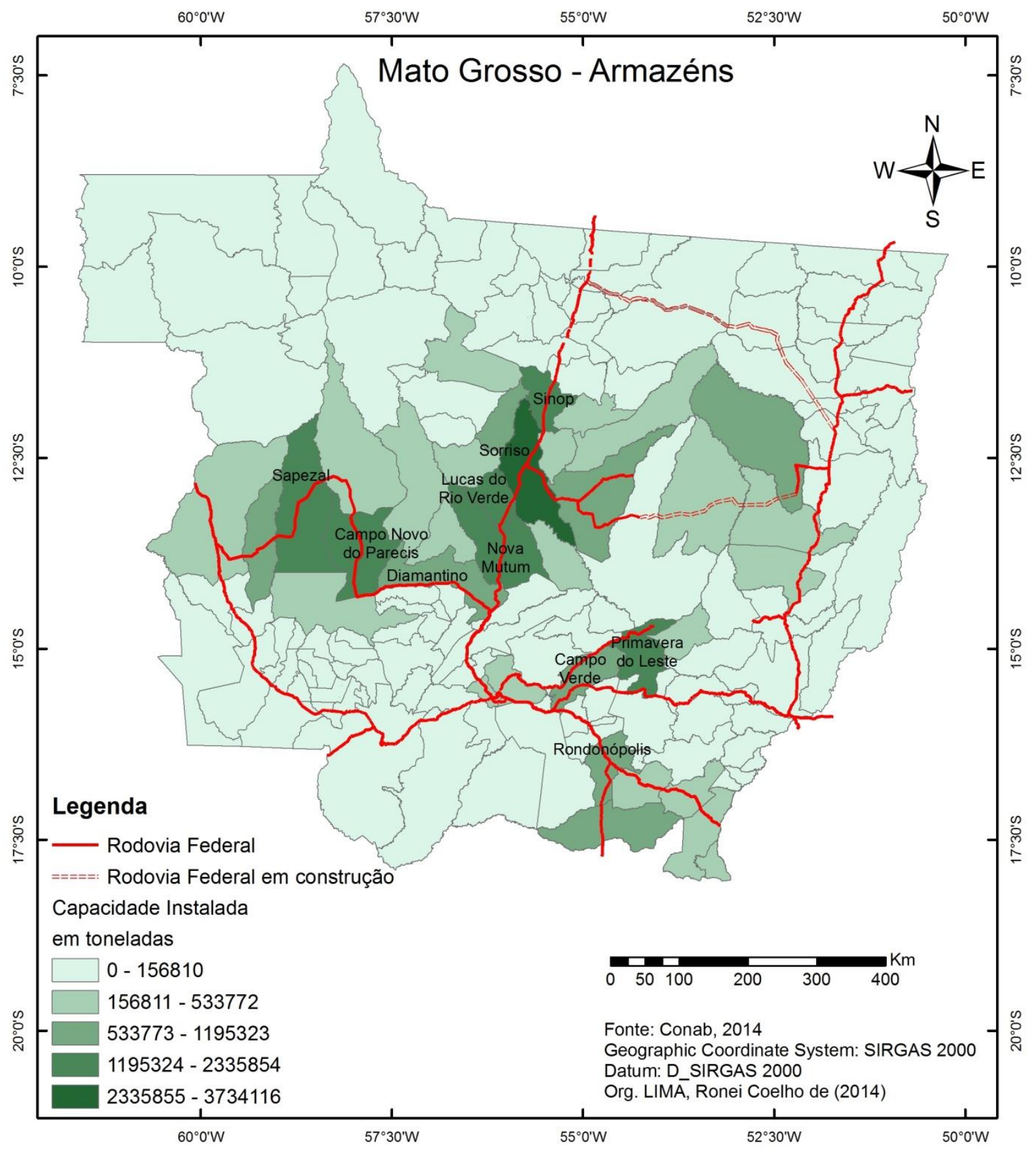

Fonte: CONAB, 2014.

Como já discutido anteriormente, se constitui em Mato Grosso um sistema de transportes rodoviário composto pelas vias principais de penetração (BR-163, e BR-158), de apoio (BR-364 e BR-070) que estão associadas às vias alimentadoras (rodovias estaduais e vicinais), sendo que nessas últimas, as dinâmicas são diversas. 
No caso das vias alimentadoras temos uma variedade de condições, pois se observa a existência de vias em leito natural (não pavimentadas), frágeis às condições climáticas e por isso não garantidora da perenidade dos fluxos; de rodovias pavimentadas de acesso liberado e de acesso condicionado ao pagamento de pedágio, como é o caso das rodovias concedidas à iniciativa privada: Rodovia da Produção (MT-235 - entre Nova Mutum e Santa Rita do Trivelato), Rodovia da Mudança (MT-449 - entre Lucas do Rio Verde e Tapurah), MT-242 (entre Sorriso e Nova Ubiratã - coincidente com BR-242; Sorriso e Ipiranga do Norte) e MT443/MT-487 (ligando o trecho da BR-163 entre Sorriso e Sinop à área conhecida como Barreiro).

Essas rodovias tiveram sua pavimentação efetuada por associações de produtores, antevendo o cenário atual o qual tem se caracterizado pelas concessões de rodovias. Outra rodovia alimentadora importante é a MT-130, que liga Rondonópolis à BR-070 e desta à Primavera do Leste, maior produtor de grãos da região.

O conjunto Primavera do Leste, Campo Verde e Santo Antônio do Leste compõe uma área concentrada de produção de soja, milho e algodão no Sudeste e Leste mato-grossense. A rodovia MT-130 passou a ter a cobrança de pedágio desde o dia 15 outubro de 2012, com a concessão ganha pela empresa Morro da Mesa Concessionária de Rodovias S/A.

Com a precarização das vias rodoviárias estaduais, e a falta de recursos para dar manutenção e ampliar a malha pavimentada, o governo do estado de Mato Grosso amplia os trechos concedidos, dessa vez com o título de Programa de Pedágios Comunitários, por meio do Decreto n ${ }^{\text {1 }}$ 185/2015 (MATO GROSSO, 2015).

Dessa forma, foram concedidos treze novos trechos de rodovias estaduais, cujas principais características são: a consolidação da articulação entre as principais áreas produtoras com os eixos de escoamentos e a manutenção da ligação por vias pavimentadas de algumas cidades das regiões Noroeste, Médio-Norte, Norte e Nordeste do estado. Assim, fica revelada a centralidade das rodovias de penetração BR-163 e BR-158, com destaque para a primeira, cuja articulação direta com as áreas mais dinâmicas de Mato Grosso, quais sejam o eixo Rondonópolis-Cuiabá e o Médio-Norte (Nova Mutum, Lucas do Rio Verde, Sorriso e Sinop) demonstra sua importância para o setor corporativo. 
Um cenário geral da estruturação do modal rodoviário no estado de Mato Grosso pode ser visualizado no Mapa 5, na qual temos identificados os principais troncos rodoviários, as rodovias de apoio e as rodovias alimentadoras.

Mapa 5 - Estrutura do modal rodoviário em Mato Grosso em 2015

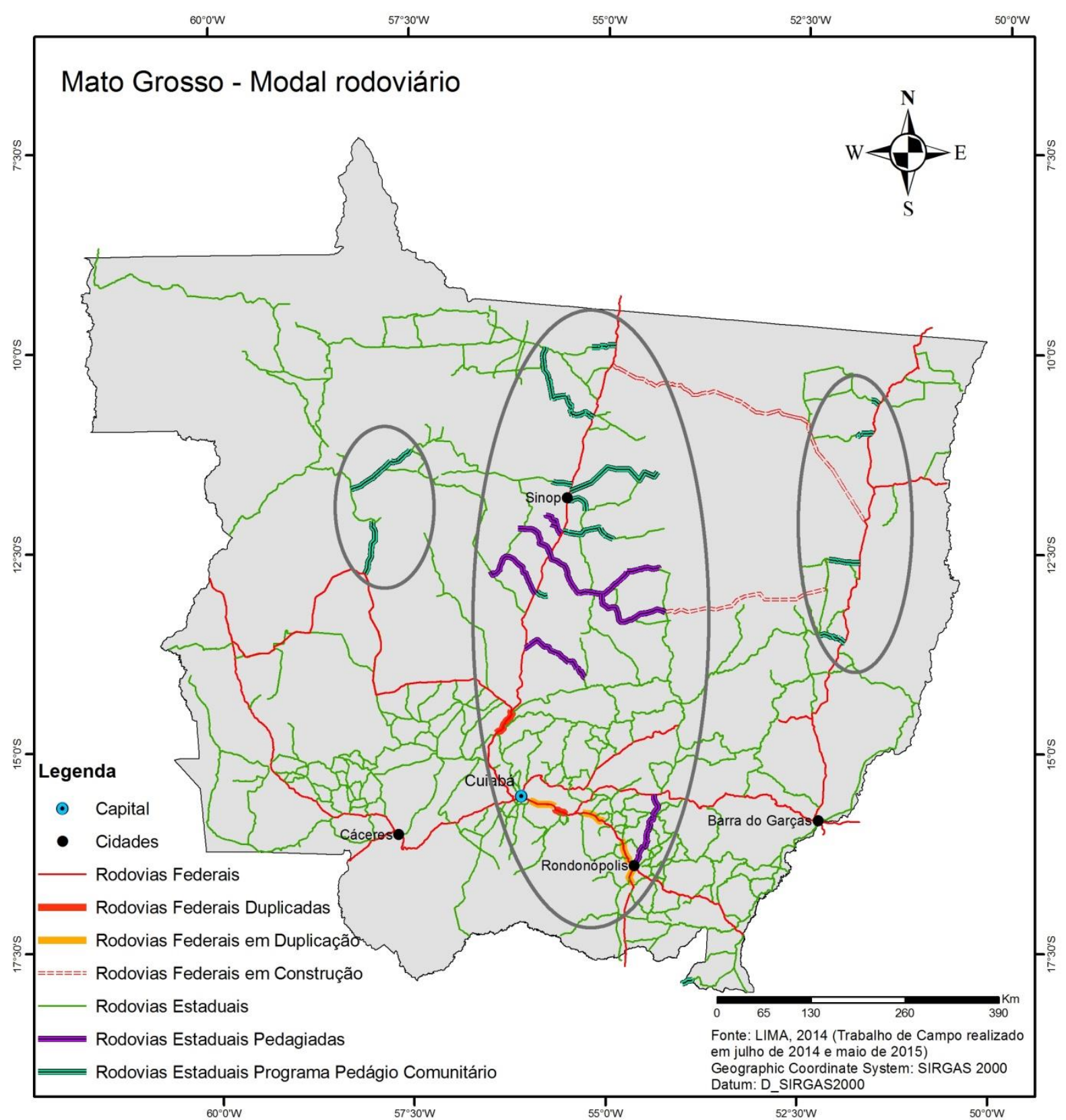

Fonte: LIMA, Ronei Coelho de, 2014 e 2015.

No seu conjunto, essas vias compõem a malha rodoviária que por sua incompletude de condições de suporte ao tráfego de cargas exige urgentemente a efetivação de intervenções estruturais e um novo arranjo com a intermodalidade. Essa reestruturação ocorre por meio das concessões das rodovias federais e estaduais, pois o Estado repassa a responsabilidade de 
ampliação e manutenção das rodovias para a iniciativa privada ou por meio de parcerias público-privadas de diversas modalidades.

No Mapa 5, é possível observar a concentração de rodovias estaduais com a cobrança de pedágio ligando as principais áreas produtoras à principal via de escoamento que é a BR163. A área concentrada da soja (BERNARDES, 2010) composta por municípios como Sorriso, Nova Mutum, Nova Ubiratã, Lucas do Rio Verde, Tapurah, entre outros, intensifica os fluxos de grãos e derivados por um lado e no sentido inverso a demanda por insumos.

Ao mesmo tempo, a reprodução da sociedade que é urbana em sua maioria exige fluxos materiais e imateriais diversos cujas bases de trafegabilidade se dão pelas redes rodoviária, aeroviária e de transmissão de energia e comunicações. Essa urbanização acelerada e hegemônica é fruto da evidente concentração do controle da produção no campo, para aquilo que Arrais (2013, p. 47) aponta como a troca de densidades, onde "a densidade humana é substituída pela densidade técnica, porta-voz da modernização", e onde a estrutura fundiária inibe a reprodução da pequena propriedade dado o modelo produtivo hegemônico.

Esse cenário se consolida porque os processos produtivos estão sob a tutela de um grupo pequeno e restrito, revelando a exclusão social do modo de produzir, já que sua constituição prima pela alta capitalização. Assim a dinâmica gerada nesse processo possibilita ondas de crescimento econômico - dependente das condições do mercado internacional - e relativo desenvolvimento social em algumas áreas e para certos grupos.

O eixo Rondonópolis-Primavera do Leste, localizado no Sul do estado, possui características parecidas, porém, enquanto a segunda, juntamente com Campo Verde se destacam pela produção, a primeira já tem constituída uma expressiva concentração industrial, principalmente de agroindústrias. Ao se efetivar a concessão da MT-130, que liga as duas principais cidades dessa região do estado, os usuários vislumbraram melhorias de trafegabilidade por meio dos aportes necessários para o trânsito de pessoas e mercadorias, notadamente as commodities. Porém, a timidez dos investimentos realizados na rodovia nos termos da concessão e a resistência de pequenos produtores, sitiantes e chacareiros (Figura 7), que se viram obrigados a arcar com os custos do pedágio para comercializarem a produção em Rondonópolis, implicaram em resistências sociais firmes (SODRÉ, 2014). 
Desse quadro surge a intervenção do poder público, por parte do Ministério Público Estadual, que em março de 2014 suspendeu a cobrança de pedágio (TONIN, 2014), pois os termos do acordo não estavam sendo respeitados.

\section{Figura 7 - Protesto de sitiantes em Rondonópolis contra a cobrança na praça de pedágio de Rondonópolis-MT}

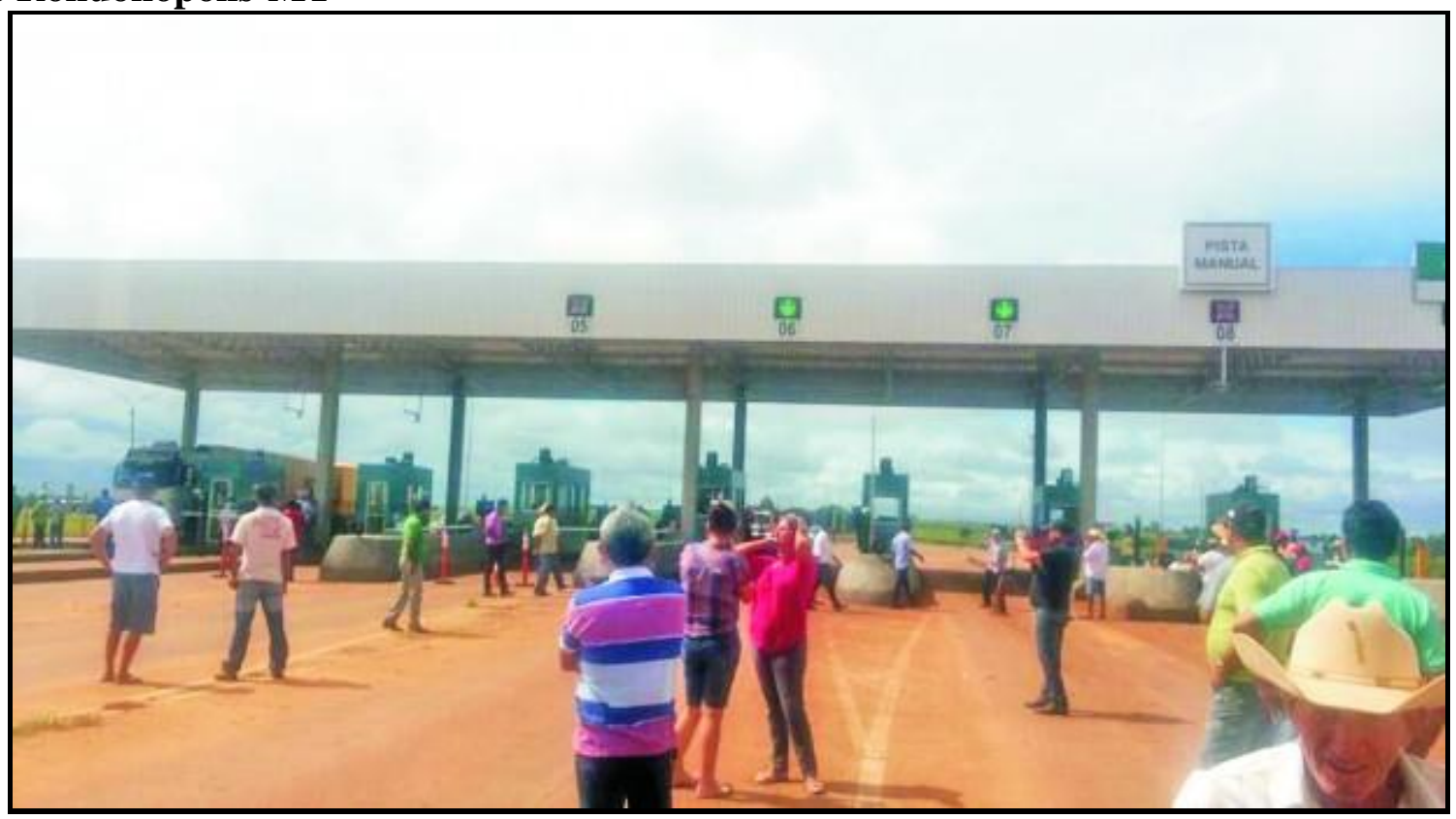

Fonte: http://www.atribunamt.com.br/2014/02/sitiantes-protestam-em-pedagio-na-mt-130/. Acesso em 19 de junho de 2014.

A medida foi suspensa em maio de 2014 por força da decisão do Tribunal de Justiça de Mato Grosso, porém ficaram evidentes as resistências existentes ao novo processo de controle da circulação de bens e pessoas pelas vias rodoviárias por meio da cobrança de pedágio, já que grande parte daqueles que trafegam por essas vias, principalmente no Sul do estado, não constituem o grupo dos agentes favorecidos pelo agronegócio, mas sim reproduzem sua condição social por meio da pequena produção e sentem mais profundamente a elevação de todo e qualquer custo.

Se produtores e transportadoras reclamam das precárias condições das vias concedidas, os pequenos produtores veem limitados os seus direitos de ir e vir, pois a condição de sobrevivência depende em parte dessa condição de comercialização de produtos nos centros urbanos, pois como aponta Lefebvre (2008) o espaço urbano por sua centralidade se destaca, é na cidade que se reúne tudo, objetos e sujeitos, daí o direito à cidade, em contraposição às ações de ordem segregadora e discriminatória. No cerne das discussões a questão dos custos, mas com realidades bem distintas entre os grupos que usam a rodovia 
MT-130, pois os primeiros prezam pela reprodução do capital e os segundos pela reprodução da vida.

A produção e a reprodução do capital necessitam da circulação, e esta demanda a existência de fixos e de fluxos sincronizados com os projetos capitalistas cujo objetivo no processo produtivo seria, em suma e de forma bastante simplificada, fazer a ligação produçãoconsumo.

Nesse sentido Silveira (2011a, p. 46) aponta:

Quanto mais imperativo de circulação do capital, mais há imperativo de expansão dos fixos e dos fluxos de transportes, de armazenagem e de comunicações. Portanto, é através da produção e da circulação que o espaço geográfico é produzido. As redes de transportes e de comunicações multimodais (flexibilidade, competência e complementaridade entre os modais) ao mesmo tempo em que são fundamentais, também têm que ser flexíveis para superarem as restrições materiais e imateriais do território e para propiciarem maior fluidez ao capital.

O autor argumenta ainda que só os fixos não bastam, pois elementos como custos, frequência, velocidade, eficiência e acessibilidade são fundamentais para a realização da fluidez do capital. Assim, cabe à logística - enquanto atributo notadamente de cunho organizacional -, disponibilizar ao capital as condições ideais para completar o processo circulatório.

Dessa forma, as condições de trafegabilidade inadequadas prejudicam o movimento do capital, assim como a falta de opções de intermodalidade. Essa realidade é menor no Sul de Mato Grosso em virtude da presença do modal ferroviário e mais acentuada no Médio-Norte, a área concentrada da produção de grãos. No Oeste, na área de produção compreendida pelos municípios de Sapezal, Campo Novo do Parecis, Diamantino e outros já existe a busca pela alternativa multimodal, rodovia (BR-364) e hidrovia (Madeira).

Apesar de se constituírem como áreas consolidadas da produção nacional, no conjunto as principais regiões produtoras de Mato Grosso enfrentam os problemas inerentes às fronteiras agrícolas, em virtude da distância juntos aos portos e aos mercados consumidores, e ao desequilíbrio da matriz de transportes em favor do modal rodoviário que é o mais caro e menos adequado ao tipo de produto transportado. 
Como argumenta Castillo (2007, p. 39) a especialização regional produtiva nas áreas de fronteira, “[...] além de implicações de ordem local (ambiental, econômica, social, política), também repercute na escala nacional através da geração de fluxos de grande volume e baixo valor agregado [...]", fluxos que demandam uma condição de fluidez que poderiam ser proporcionadas pela logística se as condições dos sistemas de engenharia de transportes e armazenagem estivessem sincronizadas com o ritmo de crescimento da produção.

As estratégias até aqui adotadas (concessões à iniciativa privada e os projetos do Estado, nos níveis estadual e federal) ainda não proporcionaram as condições adequadas à dinâmica de movimento exigida pelo capital no seu processo de produção e reprodução ampliado. As condições da MT-130, como já explicitado, é um retrato da inadequação do sistema de transportes em relação às demandas já existentes.

As principais áreas produtoras aguardam a realização dos projetos rodoviários e ferroviários em curso, conduzidos em duas frentes: os inclusos no PNLT considerados prioritários e com recursos do PAC, e aqueles relacionados com os leilões de privatização de trechos da BR-163 e BR-364 já efetivados, que serão mais detalhadamente analisados a seguir.

\subsubsection{Projetos prioritários do modal rodoviário e as concessões em Mato Grosso}

O conceito de prioridade inserido no Plano Nacional de Logística de Transportes está diretamente relacionado ao retorno econômico dos investimentos públicos efetuados no território, ou seja, a inversão de capital por parte do Estado permitirá ganhos ao setor produtivo em diversas escalas. A utilização da Taxa Interna de Retorno Econômico (TIRE), índica o caráter corporativista das ações públicas. Evidentemente ocorrem ganhos sociais amplos na criação da infraestrutura de transportes, porém o viés economicista dos projetos implica na criação e/ou manutenção da ineficiência de outros serviços públicos também essenciais.

Os rebatimentos territoriais dos investimentos previstos no PNLT, como a pavimentação de rodovias, geram alterações importantes no cotidiano das áreas atravessadas, pois acarretam valorização fundiária, que dificulta o acesso à terra aos menos capitalizados, 
pressão ambiental e, pelo aumento de fluxos materiais e imateriais, possibilita o crescimento das aglomerações do entorno.

A redução do acesso às terras rurais implica no crescimento urbano e este pressiona o poder público no oferecimento de melhores serviços nas cidades. Esse processo ocorreu nas áreas agropecuárias consolidadas, principalmente naquelas mais vinculadas ao agronegócio, e tende a se estender para as áreas de fronteira agrícola, como no eixo da BR-158, no Nordeste mato-grossense.

Ainda em fase de implantação, o único projeto rodoviário prioritário contempla uma das áreas menos integradas de Mato Grosso no sentido Leste-Oeste. Esse fenômeno de menor integração se dá em virtude da presença de terras indígenas, o que cria uma condição de precariedade da fluidez de pessoas e mercadorias, mas possibilita uma maior preservação das condições ambientais e das nações indígenas.

Assim, no PNLT temos investimentos previstos para a pavimentação da BR-080 que coincide com a MT-322 no trecho que vai de Bom Jesus do Araguaia a Peixoto de Azevedo, passando por São José do Xingu. Localizado em dois vetores, o Amazônico e o Centro Norte, o empreendimento possui uma extensão de $408 \mathrm{~km}$ e tem previsão para ser implantada até 2015. Este trecho rodoviário apresenta-se como rota de ligação de importante área de produção agropecuária, compreendida pela porção Nordeste - principal área de expansão agrícola de Mato Grosso -, com a BR-163, o que pode favorecer o escoamento da produção rumo aos portos de Miritituba e Santarém no Pará, além da ligação das rodovias federais BR163 e BR-158, na sua porção Norte.

Somando-se a essa nova rota, a pavimentação em curso da BR-242, com recursos do PAC e executada pelo DNIT, vai abranger os municípios de Canarana, Gaúcha do Norte, Nova Ubiratã, Vera, Paranatinga, Querência e Sorriso. Esse trecho rodoviário também fará a ligação das rodovias federais BR-163 e BR-158, na porção central do território matogrossense, permitindo alternativas de escoamento ao setor produtivo dessa região do estado.

Essa rota também permitirá acessar a Hidrovia Araguaia-Tocantins quando a mesma estiver em operação e seguirá paralela, com entroncamento rodoferroviário, com a futura Ferrovia de Integração do Centro-Oeste (FICO). Como a BR-242 possui um entroncamento com a MT-130, a ligação com os municípios de Primavera do Leste e Campo Verde também poderá ser fomentada. Nos Mapas 6 e 7, é possível observar a estruturação dessas novas rotas. 


\section{Mapa 6 - MT-322/BR-080}

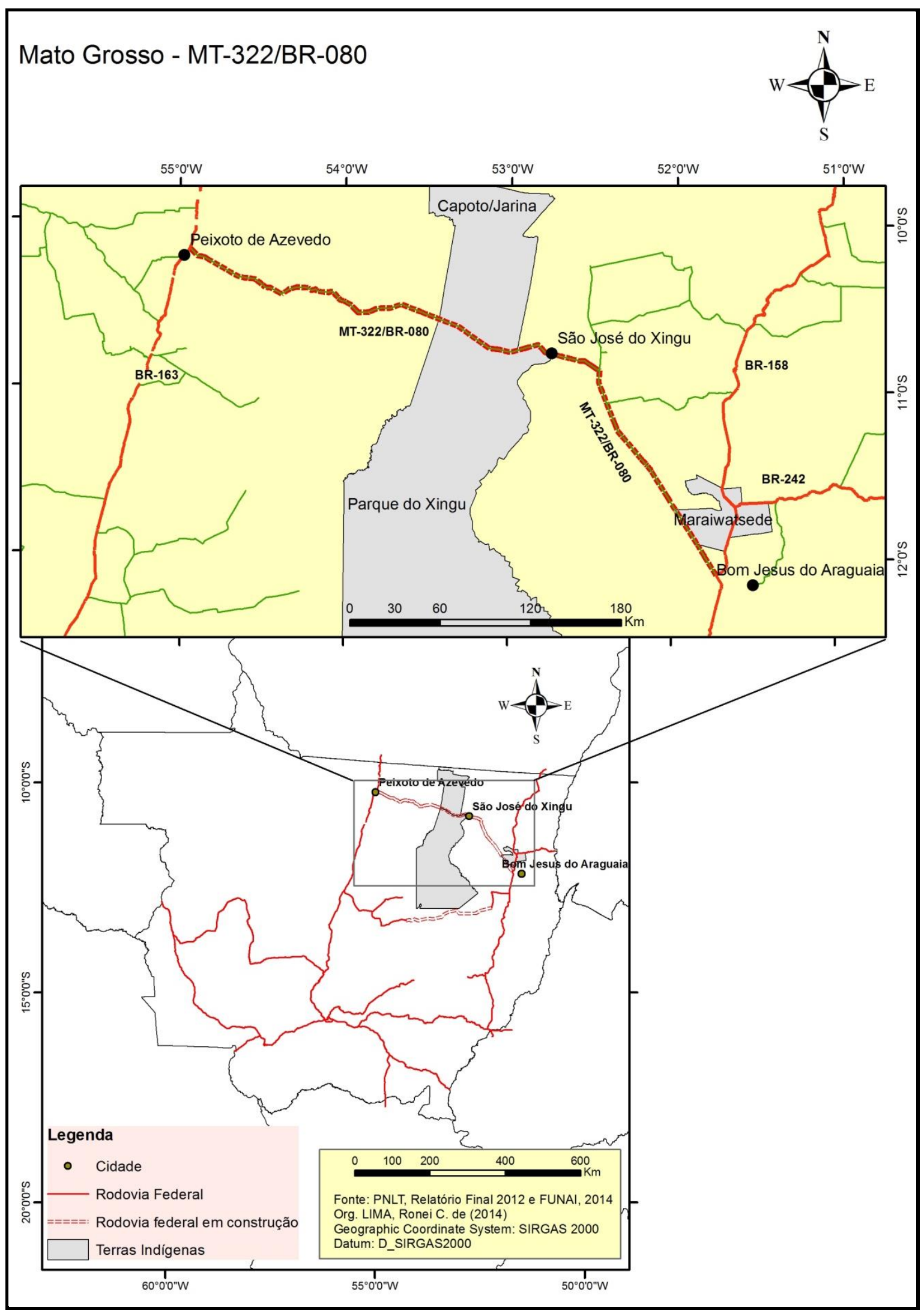

Fonte: PNLT, Relatório Final (2012) e FUNAI (2014) 
Mapa 7 - BR-242 e Ferrovia de Integração do Centro-Oeste (FICO): novas rotas da produção

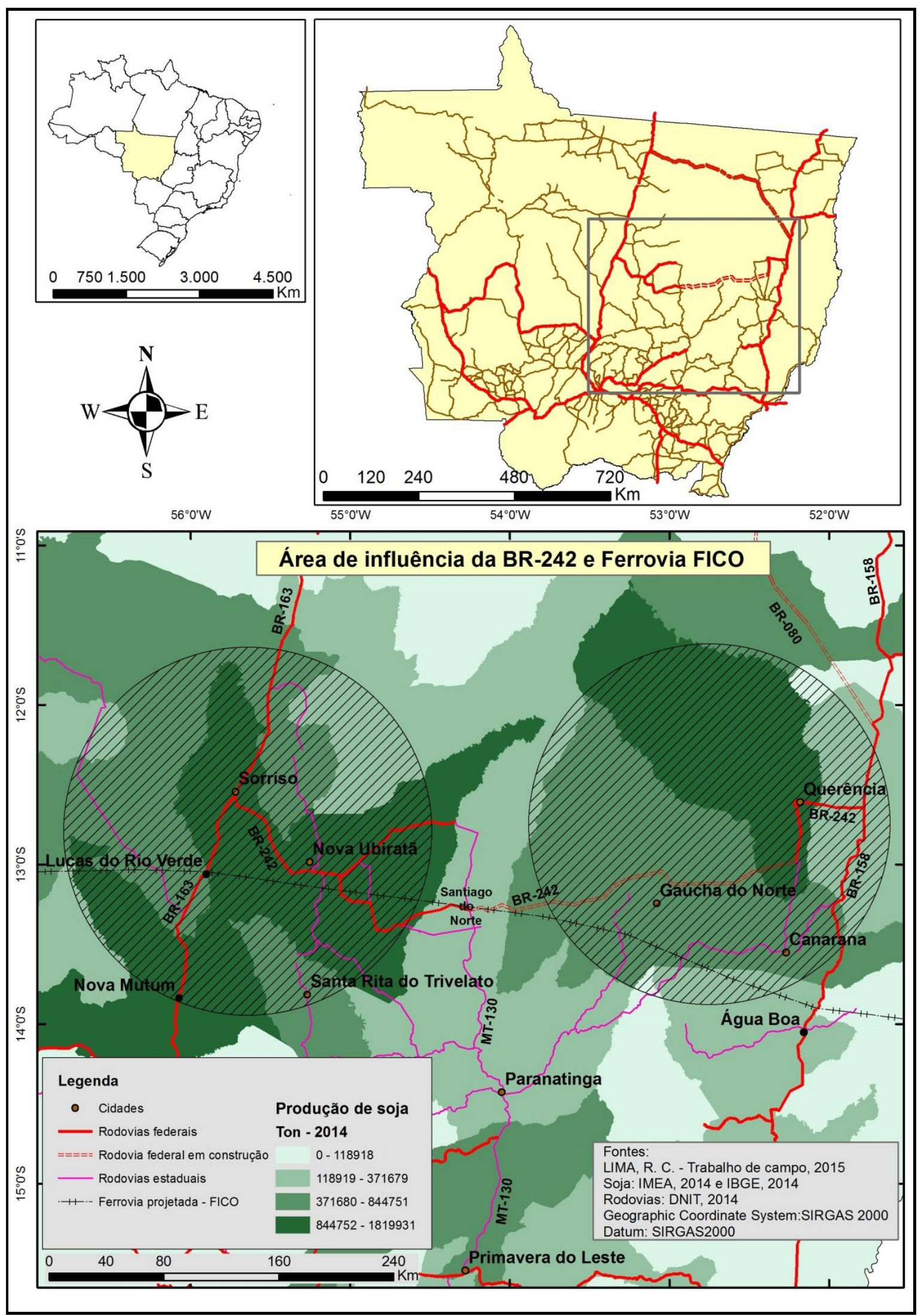

Fontes: LIMA, R. C., 2015, IMEA (2014), IBGE (2014) e DNIT (2014) 
Outro ponto fundamental sobre a malha rodoviária federal é a possibilidade da operação de concessões do setor. Essa condição se impõe pelo histórico de má gestão e de ineficiência operacional do Estado de manter a extensa rede rodoviária federal, cuja realidade apresenta problemas crônicos em relação às más condições das vias.

O movimento de concessões de rodovias tem como principal marco a criação da Lei $\mathrm{N}^{\circ} 9.277$ de 10 de Maio de 1996, que autoriza a União a delegar aos municípios, estados da Federação e ao Distrito Federal a administração e exploração de rodovias e portos federais (BRASIL, 1996b).

A criação da lei cria um evento que altera o sistema de transportes na medida em que passa a incorporar os princípios de planejamento e gestão próprios da iniciativa privada, além da condição de transferência do custo do trânsito de pessoas e/ou mercadorias para a sociedade na forma de cobrança de pedágio.

Aqui podemos falar do poder da ação do Estado, pois como ensina Santos (2008a, p. 152) “[...] uma norma pública age sobre a totalidade das pessoas, das empresas, das instituições e do território. Essa é a superioridade da ação do Estado sobre outras macroorganizações."

Agindo como ente regulador do Estado, a Agência Nacional de Transportes Terrestres (ANTT) informa que a Concessionária Rota do Oeste S.A, controlada pela Odebrecht Transport S.A (OTP) venceu o leilão de concessão da Rodovia BR-163 e MT-407 do trecho que vai da divisa de Mato Grosso com Mato Grosso do Sul até o entroncamento com a MT220. O trecho possui uma extensão total de $850,9 \mathrm{~km}$ e foi concedido a partir de 20 de março de 2014, por um período de 30 anos (BRASIL, 2014a).

Para o diretor da Associação dos Transportadores de Cargas (ATC), Miguel Mendes, as concessões e o custo do pedágio das rodovias federais, como é o caso da BR-163, é um mal necessário, porque os custos com a manutenção dos veículos terminam sendo mais onerosos para o setor de transportes do que o próprio pedágio. Para Mendes, as atuais condições das rodovias, caracterizadas pela precariedade da estrutura física, exige uma mudança de postura, qual seja, passar ao agente privado a responsabilidade de manutenção da malha rodoviária, devendo ficar para o Estado, como acontece com os países mais desenvolvidos que também se utilizam de rodovias concedidas, a responsabilidade de investir os recursos, economizados 
com as concessões do setor de transportes, em áreas como saúde e educação desde que os desvios de recursos públicos não se mantenham como prática comum.

O trecho concedido e as cidades que estão na faixa de domínio da rodovia podem ser observadas no Mapa 8.

\section{Mapa 8 - Trecho da BR-163 concedido à iniciativa privada}

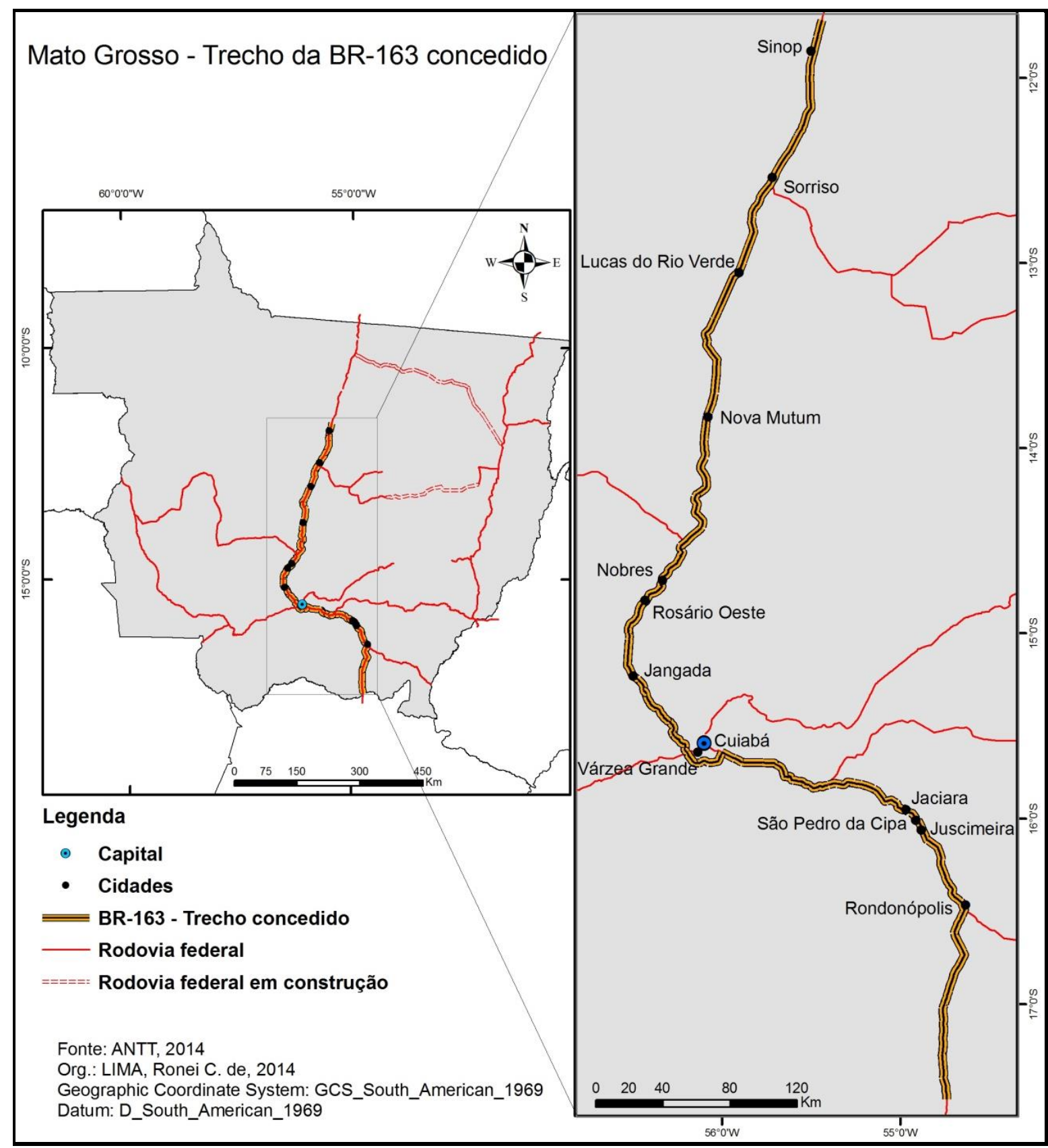

Fonte: ANTT (2014) 
Para fomentar as concessões, os investimentos exigidos nos contratos de concessão poderão contar com recursos dos bancos oficiais (BNDES, Caixa Econômica Federal e Banco do Brasil) que definiram as condições dos financiamentos destinados às concessões rodoviárias do Programa de Investimentos em Logística (PIL). Um dos principais atrativos é a flexibilização quanto às garantias, pois não será necessária a garantia corporativa já que a modalidade adotada, denominada de Project Finance, é aquela em que o próprio projeto é usado como garantia ao crédito concedido (BRASIL, 2014c).

Fica evidente que o agente público procura, com essas condições, atrair o agente privado para viabilizar os leilões dos trechos rodoviários e para não incorrer na possibilidade da não existência de propostas. Com a estratégia, continua ocorrendo a parceria entre os dois agentes, pois o mercado conta com a captação dos recursos públicos para evitar uma imobilização muito grande de capital nos empreendimentos. Com a concessão, o principal corredor de exportação de Mato Grosso passa à iniciativa privada que irá geri-lo para agilizar a fluidez corporativa de cargas, principalmente dos setores relacionados ao agronegócio, criando uma concorrência com o modal ferroviário operado pela ALL no Sul do estado.

A intensificação dos fluxos nessa rodovia federal, principal rota de escoamento da produção mato-grossense, sem os devidos acréscimos necessários na sua infraestrutura favoreceu a um processo de rigidez, na medida em que as demandas operacionais de tráfego são prejudicadas pelos congestionamentos originados por diversos motivos, a saber: pistas simples com pavimentação inadequada, travessias urbanas (ausência de anéis rodoviários), deterioração das vias pelo excesso de peso (pela ausência de fiscalização) que redundam em movimentação lenta dos veículos de carga e acidentes na via, reduzindo significativamente o ritmo de deslocamento material.

Nesse sentido, Silveira (2013, p. 45) sustenta que há um crescimento dos fluxos econômicos e "[...] das interações espaciais em um território densamente viscoso, sem a devida correspondência das infraestruturas de transportes e armazenamento." Para o autor, o crescimento dos fluxos de mercadorias, no âmbito interno e externo, passa a exercer considerável pressão sobre as infraestruturas de transportes e de armazenamento. $\mathrm{O}$ incremento técnico dos veículos de cargas do modal rodoviário permite o aumento do peso transportado sem que exista nas vias a adequação necessária para suportar a nova demanda, criando um descompasso entre as necessidades emergentes e o tempo de planejamento e intervenção por parte do gestor das vias. 
Com as concessões o Estado passa a controlar no período acordado, por meio das agências reguladoras, o ritmo dos investimentos exigidos, que no caso da BR-163 no trecho concedido são de: "recuperação, operação, manutenção, monitoração, conservação, implantação de melhorias, ampliação de capacidade e manutenção do nível de serviço do Sistema Rodoviário", como consta no contrato de concessão (BRASIL, 2014a).

Outros dois trechos de rodovias que cortam o estado de Mato Grosso tiveram autorização do Ministério dos Transportes para os estudos de viabilidade de concessão de 703,7 quilômetros das BRs-364/060/MT/GO ligando Rondonópolis (MT) a Goiânia (GO) e 976 quilômetros das BRs-163/230 que fará a ligação de Sinop em Mato Grosso ao porto de Miritituba no estado do Pará (BRASIL, 2014b).

Analisando os novos trechos, é possível vislumbrar dois cenários concorrentes, pois se o trecho entre Rondonópolis a Goiânia proporcionará a intensificação da densidade de fluxos no sentido Norte-Sul, mantendo a atual lógica, o trecho Sinop ao porto de Miritituba consolidará a tendência de movimento de cargas no sentido Sul-Norte, ou seja, ocorrerá uma inversão significativa dos fluxos materiais, podendo criar um esvaziamento relativo do trânsito de commodities no trecho que passa por Rondonópolis.

Ao mesmo tempo, porém, a dinamização do circuito produtivo nas áreas do MédioNorte mato-grossense exigirá mais insumos e poderá manter forte o fluxo Sul-Norte, pois os insumos necessários à produção são oriundos das regiões Sudeste e Sul, principalmente aqueles possuidores de maior densidade técnica e informacional (maquinário - inclusive de precisão, combustíveis, agrotóxicos, etc.).

No contexto territorial, é pertinente informar que o conjunto dos municípios cujas sedes estão no trecho concedido da BR-163, concentra aproximadamente $46 \%$ do PIB estadual, logo este eixo revela-se como o mais dinâmico de Mato Grosso e caracteriza-se, entre outros aspectos, pelos nexos diretos com a economia internacional.

Esse dinamismo, no entanto, é relativo, pois se existem espaços com certa luminosidade como Cuiabá, Rondonópolis, Várzea Grande, Sorriso, Sinop, Lucas do Rio Verde e Nova Mutum, há espaços em que a opacidade é mais abrangente, pois estes não possuem a dinâmica econômica dos demais, o que é resultado da lógica das ações efetivadas no território. Compõem esse grupo no eixo abordado da BR-163, São Pedro da Cipa, Jangada e Rosário Oeste. 
A lógica de dotação de infraestruturas logísticas para o aumento da fluidez reforça a questão das intencionalidades das ações sobre o território, pois como vimos anteriormente, as áreas de maior densidade de capital, caso das áreas produtoras de grãos, passaram a sofrer ações sistemáticas, a partir de estratégias diversas (concessões à iniciativa privada, investimentos públicos por meio de projetos prioritários) que conduzem a uma diferenciação espacial no território mato-grossense, que se dá com maior intensidade pela elevada extensão.

De acordo com Santos e Silveira (2004, p. 261-262), quando tratam da questão da fluidez no nível dos países, e aqui entendemos ser correto adotar a condição para o nível estadual,

Nos países de maior extensão territorial e que também são países com grandes disparidades regionais e de renda, o processo de criação de fluidez é seletivo e não igualitário. As regiões onde se situam produções destinadas à exportação e ao comércio distante têm prioridade nesse equipamento, criando-se no território áreas com maior densidade viária e infoviária a serviço de um dos aspectos da economia nacional.

Para os autores, a densidade viária e infoviária não está diretamente relacionada com os atributos dos lugares, como o tamanho da população e a antiguidade do povoamento, entre outros, mas sim com os nexos econômicos, principalmente aqueles voltados ao âmbito internacional.

Como adjetivamos a diferenciação interna no trecho da rodovia BR-163, é importante retomarmos a discussão da questão dos espaços luminosos e opacos, assim os primeiros são aqueles:

[...] que mais acumulam densidades técnicas e informacionais, ficando assim mais aptos a atrair atividades com maior conteúdo em capital, tecnologia e organização. Por oposição, os subespaços onde tais características estão ausentes seriam os espaços opacos.

Os autores, no entanto, asseveram que além de haver uma gama de situações intermediárias, considerar luminoso ou opaco do ponto de vista de atributos de interesse de um único grupo de atores prejudicaria a análise da organização do espaço, já que a 
simplificaria sob esse aspecto único. Logo, é limitado compreender a complexidade da questão apenas por esse viés corporativo de interesse de grandes empresas.

Mas, levantamos essa questão porque ao abordar o território como território usado, entendemos que há o favorecimento desse uso, por parte do Estado, a grupos específicos, normalmente os agentes econômicos mais articulados com o mercado internacional. Essa condição concorre para o aparecimento e/ou aprofundamento das desigualdades espaciais. Temos claro que não é possível uma produção do espaço, enquanto produção socialmente constituída, ser pautada pela igualdade, na medida em que os interesses dos diversos grupos sociais são divergentes e até antagônicos. Mas comungamos da ideia de um Estado voltado mais às questões de vulto social do que o apadrinhamento de ações corporativas, principalmente quando estas não aprofundam as relações com o lugar onde se encontram e não favorecem um ganho social mais relevante.

As ocorrências que favorecem a impressão de luminosidade e opacidade nos lugares, como se essas condições fossem únicas, na verdade ocultam a complexidade dos fenômenos realmente existentes. Assim, aprofundando o tema, Santos e Silveira (2004, p. 294) apontam que mesmo em lugares ditos luminosos há atividades consideradas opacas que podem ser oriundas de uma necessária complementaridade ou como efeito de uma desigualdade socialmente construída que permanece no território.

O uso e os rebatimentos territoriais do eixo da BR-163, efetivados pelos diversos agentes sociais, revelam concretamente a complexidade dos elementos que constituem o fenômeno em si. Assim, a mesma via pode apenas atravessar uma área - efeito de ponte ou túnel como destacam Vencovsky e Castillo (2007, p. 131) ao tratarem das ferrovias no Brasil -, ou ainda, pode ampliar significativamente as articulações desta com outras escalas, inclusive a escala global, caso das áreas conectadas com o mercado de commodities.

As vantagens dos dois fenômenos são relativas, pois se naqueles em que o efeito de atravessamento não repercute favoravelmente para grande parte da sociedade, para aqueles possuidores de nexos econômicos ampliados, os efeitos positivos se concentram nos agentes hegemônicos e apenas resvalam nos demais grupos.

Esse fato pode ser corroborado pelo argumento de Castillo (2004, p. 88-91), que ancorado pela obra de Galvão e Brandão (2003), discute os resultados da estruturação do sistema de transportes, entendendo que esta redundou em uma ligação ponto-a-ponto - como 
no caso dos ENIDs -, onde as áreas pujantes no tocante à produção para exportação são ligadas aos mercados internacionais, não configurando uma integração das diversas áreas entre si. Aponta que mesmo entre as áreas pujantes não há uma integração, pois estas se conectam diretamente com o mercado exterior.

A preocupação do retorno econômico das vias (rodoviárias, ferroviárias, hidroviárias) nos projetos considerados prioritários no PNLT e operacionalizados no PAC 1 e 2, revelam que a topologia (traçados das vias) tiveram pouca inovação e mantém a essência do sistema de corredores de exportação, na medida em que poucas ações são efetivadas no sentido de uma maior integração espacial.

Apesar do campo das possibilidades ter sido alavancado sobremaneira com o anúncio de projetos ferroviários e hidroviários nos programas governamentais em associação com a iniciativa privada - caso da Ferrovia de Integração Centro-Oeste (FICO) e das hidrovias Araguaia-Tocantins e Teles Pires-Juruena-Tapajós -, a realidade continua sendo a hegemonia do modal rodoviário, e este se apresenta disposto no território como elemento de ligação da produção ao mercado externo.

Essa ligação direta, ainda que irracional sob a lógica capitalista, na medida em que o modal é inapropriado pelas distâncias percorridas, é ainda mais irracional do ponto de vista social, pois não proporciona uma integração mais efetiva de áreas pouco articuladas, criando um estado de manutenção do status quo caracterizado pela pouca fluidez em grande parte do território mato-grossense. A lógica da pavimentação da MT-322/BR-080, já discutida anteriormente (ver Mapa 6), considerada prioritária no PNLT, favorecerá a articulação do novo front agrícola de Mato Grosso com a nova saída para o Norte. É o império da lógica corporativa e seu domínio sobre o território.

No entanto, uma nova realidade da logística de transportes começa a operar no território, apesar de se espacializar em uma área concentrada - Sul/Sudeste de Mato Grosso: Rondonópolis, Itiquira, Alto Araguaia e Alto Taquari -, mas com repercussões sobre extensa área. A efetivação do modal ferroviário implicou em uma nova reconfiguração de fluxos, mas mantendo o mesmo sentido que o modal rodoviário (Norte-Sul), impactando desigualmente direta e indiretamente as áreas atravessadas. A constituição desse novo fenômeno será analisada a seguir, quando tratamos da realidade inerente a essa nova articulação espacial. 


\subsection{O NOVO ELEMENTO DA LOGÍSTICA DE TRANSPORTE EM MATO GROSSO: A FERROVIA}

O sistema ferroviário brasileiro possui a sua constituição guiada pela dinâmica dos setores produtivos e dos interesses corporativos e estatais, sendo que na sua gênese, denominada de criação e expansão (1835-1957) a iniciativa privada comanda o processo com investimentos em linhas que serviriam à movimentação de fluxos diversos, notadamente da produção de café. Posteriormente (1957-1996) temos o período de estatização e readequação, objetivando favorecer o fluxo de commodities (minérios) e passageiros e, finalmente, a fase de desestatização e recuperação (desde 1996) retornando o controle do setor à iniciativa privada buscando otimizar os fluxos de commodities (minérios e soja) e containers, conforme apontam em quadro-síntese Vencovsky e Castillo (2007, p. 122).

Essas alterações que segundo os autores comportam cerca de 150 anos da história do sistema ferroviário é um esboço do contínuo vínculo da estruturação do sistema de transportes brasileiro com a matriz econômica de base exportadora, o que provocou um atraso na criação de um sistema mais racional sob uma lógica mais social (ampla) em detrimento de uma lógica corporativa (específica).

Para Barat (1973, p. 117):

Apesar da sua importância fundamental para o desenvolvimento da economia brasileira, o setor de transportes sofreu historicamente uma quase completa ausência de integração, entre as suas diferentes modalidades, e deficiências na coordenação das políticas modais.

Este quadro retratado pelo autor, que compreende o período que culmina na década de 1970, decorria segundo seu entendimento, da falta de planejamento dos investimentos no setor de transportes, bem como na ausência de sincronia destes investimentos com o restante da economia.

Com isto havia grande desperdício de recursos públicos e a escassez destes implicava na redução drástica dos investimentos nos períodos de crise. A criação do Grupo Executivo de Integração da Política de Transportes (GEIPOT), em 1965, não conseguiu maior êxito, pois 
não apresentava uma subordinação a um planejamento mais global (mais completo) e, assim, não evoluiu de forma satisfatória (BARAT, 1973).

A própria busca sistemática por uma estruturação do sistema de transportes voltada à extroversão (CASTILLO, 2011) implicou na pouca articulação interna mais abrangente, com foco apenas nos produtos mais rentáveis e aceitos no mercado internacional em detrimento do mercado interno, portanto, voltando-se para uma lógica externa. Essa lógica, no entanto, se baseava na proposta de modernização ligada às exportações.

Nesse sentido, quando argumentam sobre o mercado nacional e a sua importância para uma maior disponibilidade de bem estar social para os países pobres, Santos e Silveira (2004, p. 298) acrescentam que há um processo de privilegiar o mercado externo e que:

\begin{abstract}
A globalização acelera este último processo, porque faz parte do seu credo a idéia de que sem exportar é impossível modernizar-se e participar plenamente. De fato, o que resulta na prática é a vitória de uma lógica econômica a despeito das distorções de ordem social que possa acarretar. A consequente divisão do trabalho passa a ser comandada de fora do interesse social.
\end{abstract}

Para os autores, tomados em conjunto esses processos determinam consequências relevantes para o funcionamento do espaço, e com rebatimentos na sua estruturação. Com isso, de forma cíclica, temos um retorno das ações sobre a sociedade e economia.

Ao concentrar esforços em objetivos bastantes específicos, qual seja o favorecimento de fluxos materiais de caráter extrovertido, sob a lógica externa, as articulações internas, notadamente mais abrangentes socialmente, se tornam dependentes de projetos e investimentos residuais por não se tratarem de prioridade para os agentes hegemônicos.

Quanto ao processo de estruturação do sistema ferroviário no Brasil, este, ao seguir demasiadamente a lógica do mercado exportador, negligenciou a dinâmica interna que se organizava com base em uma industrialização que demandava articulação interna crescente. Assim, ao somarmos à rigidez natural deste modal, frente à flexibilidade do modal rodoviário - que implicava em maiores dificuldades do primeiro de se reorganizar espacialmente -, com os interesses do Estado em incentivar o modal rodoviário, temos a constituição da gênese da crise do setor ferroviário no nível nacional. 
E, ao destacar a sua estruturação e a origem da sua crise no conjunto de setor de transportes no Brasil, Barat (1973, p. 125) entende que:

\begin{abstract}
O sistema ferroviário brasileiro implantado para atender às necessidades de uma economia exportadora de produtos primários - com ferrovias dirigidas do interior para os portos regionais - revelou-se inadequado para responder aos estímulos do intenso processo de industrialização, iniciado a partir da década de 1930. As profundas transformações estruturais da economia brasileira colocaram gradativamente, como elementos mais importantes no movimento geral de carga, os fluxos de bens intermediários e finais para $\mathrm{o}$ atendimento do mercado interno.
\end{abstract}

Para o autor, a complexificação das operações oriundas da industrialização interna não foi acompanhada pelo setor ferroviário. Este não se mostrou flexível e eficiente para atender a nova realidade produtiva.

Esse fenômeno decorre do fato do sistema econômico primário-exportador nacional se caracterizar pela agregação de "economias exportadoras regionais, isoladas uma das outras" (BARAT, op. cit., p. 125). Com uma nova realidade produtiva, os antigos traçados e as diferentes bitolas impediam uma integração da malha já existente, da mesma forma, os elevados custos para a construção bem como a demora de retorno dos investimentos favoreceram a inércia e o sucateamento do setor. Esse quadro beneficiou a expansão do sistema rodoviário que emerge como modal hegemônico na consolidação de um mercado nacional expressivo.

Campos e Almeida (2014, p. 74) ainda apontam a crise do petróleo e as demais crises desencadeadas a partir dos anos 1970, como fatores complicadores para o sistema ferroviário sob a égide da Rede Ferroviária Federal, expondo que "Diante de uma conjuntura insustentável, os investimentos na malha ferroviária reduziram drasticamente, havendo o sucateamento da infraestrutura e o crescimento das dívidas da empresa.". As autoras lembram que em 1992 inicia-se o processo de privatizações do setor mediante concessões aos operadores privados.

Fazendo uma contextualização mais recente, Vencovsky e Castillo (2007, p. 120) propõem que o sistema ferroviário, a partir de 1996, se caracterizou pelo partilhamento da rede e pelas concessões junto à iniciativa privada. Com isso, ocorre uma radicalização da 
principal característica desse sistema, qual seja, “[...] sua topologia extravertida, funcional à exportação de commodities minerais e agrícolas, sobretudo.” com isso, a maior parte dos investimentos no setor ferroviário tem por objetivo "[...] promover uma fluidez corporativa, exemplificada pelo escoamento da soja produzida nos fronts agrícolas do Cerrado e destinada aos portos exportadore" (VENCOVSKY; CASTILLO, op. cit., p. 120).

Para os autores, as regiões produtivas mais dinâmicas são caracterizadas pelos vetores de modernização - cuja lógica é a seletividade e o caráter excludente -, e pela distância excessiva dos portos exportadores. Por isto, demandam dos agentes, principalmente do Estado, a instalação de novos sistemas de engenharia para permitir a fluidez de commodities. Este é caso da soja produzida no interior do país que busca melhores condições de transporte para ser mais competitiva junto ao mercado internacional.

Santos (2008a) esclarece que essas áreas acomodam pontos cujas características são distintas, mas solidárias. De um lado temos extensões constituídas de pontos agregados sem ruptura, como na definição convencional de região, que podem ser chamadas de horizontalidades, de outro lado, temos pontos descontínuos, cuja função é promover o funcionamento global da sociedade como um todo e da economia. Para o autor:

O espaço se compõe de uns e de outros desses recortes, inseparavelmente. [...] Enquanto as horizontalidades são, sobretudo, a fábrica da produção propriamente dita e o locus de uma cooperação mais limitada, as verticalidades dão, sobretudo, conta dos outros momentos da produção (circulação, distribuição, consumo), sendo o veículo de uma cooperação mais ampla, tanto econômica e politicamente, como geograficamente. (SANTOS, op. cit., p. 284).

Analisando o sistema de movimento ferroviário no Brasil, Contel (2004, p. 371) entende que esse promove a criação de horizontalidades e verticalidades. As horizontalidades estariam vinculadas à reprodução da vida da população, como no caso do transporte urbano e no transporte de gêneros alimentícios nas regiões Sul e Sudeste. Quanto às verticalidades, argumenta que uma parcela da malha que transporta os gêneros alimentícios, se soma com as ferrovias vinculadas ao transporte de minérios, contribuindo "[...] nos chamados corredores de exportação, para a formação de solidariedades organizacionais no território”. 
Para o autor, com o apoio técnico e financeiro do governo federal, esse circuito de produção e escoamento é composto de um conjunto de sistemas de engenharia compatível em modernidade com as exigências do mercado mundial, mas restringindo-se a certos grupos de produtos, como é o caso da soja no setor de alimentos.

A análise ratifica a corporatização do território na medida em que a criação dos sistemas de engenharia busca a otimização da produção, circulação e consumo no nível dos produtos voltados à exportação. As horizontalidades mais amplas criadas no processo são residuais, pois o foco é a produção direcionada aos mercados externos, fato que alavanca a relevância das verticalidades construídas.

Quanto às concessões dos serviços ferroviários no Brasil, temos, de acordo com o Relatório Anual de Acompanhamento das Concessões Ferroviárias para o ano de 2013, as seguintes ferrovias: América Latina Logística Malha Norte S.A. (ALLMN); América Latina logística Malha Oeste S.A. (ALLMO); América Latina Logística Malha Paulista S.A. (ALLMP); América Latina Logística Malha Sul S.A. (ALLMS); Estrada de Ferro Carajás (EFC); Estrada de Ferro Vitória a Minas (EFVM); Ferrovia Centro-Atlântica S.A. (FCA); Estrada de Ferro Paraná - Oeste S.A. (FERROESTE); Ferrovia Norte Sul Tramo Norte (FNSTN); Ferrovia Tereza Cristina S.A. (FTC); MRS Logística S.A.; e Transnordestina Logística S.A. (TLSA ); (BRASIL, 2014d).

O Quadro 8, apresenta as principais características de cada uma das ferrovias concedidas.

\begin{tabular}{|c|c|c|c|c|c|c|}
\hline Ferrovia & $\begin{array}{l}\text { Área de } \\
\text { Atuação }\end{array}$ & $\begin{array}{l}\text { Extensão } \\
(\mathbf{k m})\end{array}$ & $\begin{array}{c}\text { Bitola } \\
(\mathrm{m})\end{array}$ & $\begin{array}{c}\text { Pontos de } \\
\text { Interconexão com } \\
\text { Ferrovias }\end{array}$ & $\begin{array}{l}\text { Pontos de } \\
\text { Interconexão } \\
\text { com Portos }\end{array}$ & $\begin{array}{c}\text { Principais } \\
\text { produtos } \\
\text { transportados }\end{array}$ \\
\hline ALLMN & $\begin{array}{l}\text { Mato Grosso } \\
\text { e Mato } \\
\text { Grosso do Sul }\end{array}$ & 617 & 1,60 & $\begin{array}{l}\text { Marco Inicial - SP (ALLMP - América } \\
\text { Latina Logística Malha Paulista S.A) }\end{array}$ & Não há & $\begin{array}{l}\text { Soja, Farelo de } \\
\text { soja, Milho, } \\
\text { Combustíveis, } \\
\text { Derivados do } \\
\text { Petróleo e } \\
\text { Álcool, } \\
\text { Contêiner e } \\
\text { Extração vegetal } \\
\text { e Celulose }\end{array}$ \\
\hline ALLMO & $\begin{array}{l}\text { São Paulo e } \\
\text { Mato Grosso } \\
\text { do Sul }\end{array}$ & 1.945 & 1,00 & $\begin{array}{l}\text { Iperó - SP (ALLMS - América Latina } \\
\text { Logística Malha Sul S.A). Rubião } \\
\text { Junior - SP (ALLMS). Alumínio - SP } \\
\text { (ALLMP - América Latina Logística } \\
\text { Malha Paulista S.A). Bauru - SP } \\
\text { (ALLMP - América Latina Logística } \\
\text { Malha Paulista S.A). Mairinque - SP } \\
\text { (ALLMP - América Latina Logística } \\
\text { Malha Paulista S.A). Empresa } \\
\text { Ferroviária Oriental (BOLÍVIA) }\end{array}$ & $\begin{array}{l}\text { Porto } \\
\text { Esperança } \\
\text { (MS) - } \\
\text { Terminal } \\
\text { Hidroviário } \\
\text { e } \\
\text { Ladário (MS) - } \\
\text { Terminal } \\
\text { Hidroviário }\end{array}$ & $\begin{array}{l}\text { Combustíveis, } \\
\text { Derivados do } \\
\text { Petróleo e } \\
\text { Álcool, Granéis } \\
\text { Minerais, } \\
\text { Indústria } \\
\text { Siderúrgica, } \\
\text { Minério de } \\
\text { Ferro, Adubos e } \\
\text { Fertilizantes, } \\
\text { Extração } \\
\text { Vegetal e } \\
\text { Celulose }\end{array}$ \\
\hline ALLMP & São Paulo & 1.945 & $\begin{array}{c}1,60 \\
(1.463\end{array}$ & $\begin{array}{l}\text { Boa Vista Nova - SP (FCA - Ferrovia } \\
\text { Centro-Atlântica S.A). }\end{array}$ & $\begin{array}{l}\text { Santos-SP, } \\
\text { Pederneiras - }\end{array}$ & $\begin{array}{l}\text { Combustíveis, } \\
\text { Derivados do }\end{array}$ \\
\hline
\end{tabular}




\begin{tabular}{|c|c|c|c|c|c|c|}
\hline & & & $\begin{array}{c}\mathrm{km}) ; \\
1,00 \\
(243 \mathrm{~km}) \\
\mathrm{e} \\
1,00 / 1,60 \\
(283 \mathrm{~km})\end{array}$ & $\begin{array}{l}\text { Replan/Paulinia - SP (FCA - Ferrovia } \\
\text { Centro-Atlântica S.A). Jundiaí - SP } \\
\text { (MRS - MRS Logística S.A). Lapa - } \\
\text { SP (MRS - MRS Logística S.A). } \\
\text { Perequê - SP (MRS - MRS Logística } \\
\text { S.A). Alumínio - SP (ALLMO - } \\
\text { América Latina Logística Malha } \\
\text { Oeste S.A). Mairinque - SP (ALLMO - } \\
\text { América Latina Logística Malha } \\
\text { Oeste S.A). Bauru - SP (ALLMO - } \\
\text { América Latina Logística Malha } \\
\text { Oeste S.A). Marco Inicial - SP } \\
\text { (ALLMN - América Latina Logística } \\
\text { Malha Norte S.A). }\end{array}$ & $\begin{array}{l}\text { SP e } \\
\text { Panorama - } \\
\text { SP }\end{array}$ & $\begin{array}{l}\text { Petróleo e } \\
\text { Álcool, } \\
\text { Indústria } \\
\text { Siderúrgica, } \\
\text { Conteiner, } \\
\text { Adubos e } \\
\text { Fertilizantes, } \\
\text { Açúcar e } \\
\text { Granéis minerais }\end{array}$ \\
\hline ALLMS & $\begin{array}{l}\text { Rio Grande do } \\
\text { Sul, Santa } \\
\text { Catarina, } \\
\text { Paraná e São } \\
\text { Paulo }\end{array}$ & 7.265 & $\begin{array}{c}1,00 \\
(7.254 \\
\mathrm{km}) \\
\mathrm{e} \\
1,44 \\
(11 \mathrm{~km})\end{array}$ & $\begin{array}{l}\text { Rubião Junior - SP (ALLMO - } \\
\text { América Latina Logística Malha } \\
\text { Oeste S.A). Iperó - SP (ALLMO - } \\
\text { América Latina Logística Malha } \\
\text { Oeste S.A). Guarapuava - PR } \\
\text { (Ferroeste - Estrada de Ferro Paraná } \\
\text { Oeste S.A). Santana do Livramento - } \\
\text { RS (AFE - Administración de } \\
\text { Ferrocarriles del Estado - Uruguai) } \\
\text { Uruguaiana - RS (Ferrocarril } \\
\text { Mesopotamico General Orquiza - } \\
\text { Argentina) }\end{array}$ & $\begin{array}{l}\text { Presidente } \\
\text { Epitácio(SP), } \\
\text { Paranaguá } \\
\text { (PR), São } \\
\text { Francisco do } \\
\text { Sul (SC), } \\
\text { Porto Alegre } \\
\text { (RS), Rio } \\
\text { Grande (RS) e } \\
\text { Estrela (RS) } \\
\text { (Terminal } \\
\text { Hidroviário) }\end{array}$ & $\begin{array}{l}\text { Combustíveis, } \\
\text { Derivados do } \\
\text { Petróleo e } \\
\text { Álcool, } \\
\text { Carvão/Coque, } \\
\text { Cimento, } \\
\text { Granéis } \\
\text { Minerais, } \\
\text { Indústria } \\
\text { Cimenteira e } \\
\text { Construção Civil, } \\
\text { Indústria } \\
\text { Siderúrgica, } \\
\text { Carga Geral } \\
\text { (Não } \\
\text { Conteinerizada), } \\
\text { Conteiner, } \\
\text { Adubos e } \\
\text { Fertilizantes, } \\
\text { Extração } \\
\text { Vegetal e } \\
\text { Celulose, } \\
\text { Açúcar, Milho, } \\
\text { Trigo, Outros } \\
\text { (Produção } \\
\text { agrícola), Soja e } \\
\text { Farelo de Soja }\end{array}$ \\
\hline EFVM & $\begin{array}{l}\text { Espírito Santo } \\
\text { e Minas } \\
\text { Gerais }\end{array}$ & 905 & 1,00 & $\begin{array}{l}\text { Ouro Branco - MG (MRS Logística } \\
\text { S.A.) Pedro Nolasco - ES (FCA - } \\
\text { Ferrovia Centro-Atlântica S.A.) Engo } \\
\text { Lafaiete Bandeira - MG (FCA - } \\
\text { Ferrovia Centro-Atlântica S.A.) } \\
\text { Capitão Eduardo - MG (FCA - } \\
\text { Ferrovia Centro-Atlântica S.A.) } \\
\text { Pedreira do Rio das Velhas - MG } \\
\text { (FCA - Ferrovia Centro- Atlântica } \\
\text { S.A.) }\end{array}$ & Tubarão (ES) & $\begin{array}{l}\text { Combustíveis, } \\
\text { Derivados do } \\
\text { Petróleo e } \\
\text { Álcool, } \\
\text { Carvão/Coque, } \\
\text { Granéis } \\
\text { Minerais, } \\
\text { Indústria } \\
\text { Cimenteira e } \\
\text { Construção Civil, } \\
\text { Indústria } \\
\text { Siderúrgica, } \\
\text { Minério de Ferro } \\
\text { Adubos e } \\
\text { Fertilizantes, } \\
\text { Extração } \\
\text { Vegetal e } \\
\text { Celulose }\end{array}$ \\
\hline FCA & $\begin{array}{l}\text { Sergipe, } \\
\text { Espirito Santo, } \\
\text { Rio de } \\
\text { Janeiro, São } \\
\text { Paulo, Minas } \\
\text { Gerais, Goiás, } \\
\text { Distrito } \\
\text { Federal, e } \\
\text { Bahia }\end{array}$ & 8.066 & $\begin{array}{c}1,00 / 1,60 \\
(169 \mathrm{~km}) \\
\mathrm{e} \\
1,00 \\
(7.897 \\
\mathrm{km})\end{array}$ & $\begin{array}{l}\text { Pedro Nolasco - ES (EFVM - Estrada } \\
\text { de Ferro Vitória a Minas) Capitão } \\
\text { Eduardo - MG (EFVM ), Engo } \\
\text { Lafaiete Bandeira - MG (EFVM) } \\
\text { Pedreira do Rio das Velhas - MG } \\
\text { (EFVM) Propriá - SE (TLSA - } \\
\text { Transnordestina Logística S.A.) Boa } \\
\text { Vista Nova - SP (ALLMP - América } \\
\text { Latina Logística Malha Paulista S.A.) } \\
\text { Paulínia / Replan - SP (ALLMP) } \\
\text { Barão de Angra - RJ (MRS - MRS } \\
\text { Logística S.A.) Bárbará - RJ (MRS) } \\
\text { Barreiro - RJ (MRS) Miguel Burnier - } \\
\text { MG (MRS) Três Rios - RJ (MRS - } \\
\text { MRS Logística S.A.) Engo Lafaiete } \\
\text { Bandeira - MG (MRS - MRS }\end{array}$ & $\begin{array}{l}\text { Angra dos } \\
\text { Reis (RJ), } \\
\text { Aracaju (SE), } \\
\text { Aratu (BA) e } \\
\text { Salvador (BA) }\end{array}$ & $\begin{array}{l}\text { Combustíveis, } \\
\text { Derivados do } \\
\text { Petróleo e } \\
\text { Álcool, Cimento, } \\
\text { Granéis } \\
\text { Minerais, } \\
\text { Indústria } \\
\text { Cimenteira e } \\
\text { Construção Civil } \\
\text { Indústria } \\
\text { Siderúrgica, } \\
\text { Minério de } \\
\text { Ferro, Carga } \\
\text { Geral (Não } \\
\text { Conteinerizada), } \\
\text { Conteiner, }\end{array}$ \\
\hline
\end{tabular}




\begin{tabular}{|c|c|c|c|c|c|c|}
\hline & & & & Logística S.A.) & & $\begin{array}{l}\text { Adubos e } \\
\text { Fertilizantes, } \\
\text { Extração } \\
\text { Vegetal e } \\
\text { Celulose, } \\
\text { Açúcar, Milho, } \\
\text { Soja e Farelo de } \\
\text { Soja }\end{array}$ \\
\hline Ferroeste & Paraná & 248 & 1,00 & $\begin{array}{l}\text { Ferrovias Guarapuava (PR) - ALLMP } \\
\text { - América Latina Logística Malha Sul } \\
\text { S.A). }\end{array}$ & Não há & $\begin{array}{l}\text { Carga Geral } \\
\text { (Não } \\
\text { conteinerizada), } \\
\text { Milho, Trigo, } \\
\text { Óleo Vegetal, } \\
\text { Soja e Farelo de } \\
\text { Soja e Conteiner }\end{array}$ \\
\hline FNSTN & $\begin{array}{l}\text { Maranhão e } \\
\text { Tocantins }\end{array}$ & 720 & 1,60 & $\begin{array}{l}\text { Açailândia - MA (EFC - Estrada de } \\
\text { Ferro Carajás) }\end{array}$ & Não há & $\begin{array}{l}\text { Combustíveis, } \\
\text { Derivados do } \\
\text { Petróleo e } \\
\text { Álcool, Minério } \\
\text { de Ferro, Milho, } \\
\text { Soja e Farelo de } \\
\text { Soja }\end{array}$ \\
\hline FTC & $\begin{array}{l}\text { Santa } \\
\text { Catarina }\end{array}$ & 164 & 1,00 & Não há & Imbituba (SC) & $\begin{array}{l}\text { Carvão/Coque e } \\
\text { Conteiner }\end{array}$ \\
\hline MRS & $\begin{array}{l}\text { Rio de } \\
\text { Janeiro, São } \\
\text { Paulo e Minas } \\
\text { Gerais }\end{array}$ & 1.674 & $\begin{array}{c}, 00 / 1,60 \\
(42 \mathrm{~km}) \\
\mathrm{e} \\
1,60 \\
(1.632 \\
\mathrm{km})\end{array}$ & $\begin{array}{l}\text { Barão de Angra - RJ (FCA - Ferrovia } \\
\text { Centro-Atlântica S.A.) Barbará - RJ } \\
\text { (FCA - Ferrovia Centro-Atlântica } \\
\text { S.A.) Engo Lafaiete Bandeira - MG } \\
\text { (FCA - Ferrovia Centro-Atlântica } \\
\text { S.A.) Barreiro - MG (FCA - Ferrovia } \\
\text { Centro-Atlântica S.A.) Miguel Burnier } \\
\text { - MG (FCA - Ferrovia Centro- } \\
\text { Atlântica S.A.) Três Rios - RJ (FCA - } \\
\text { Ferrovia Centro-Atlântica S.A.) Ouro } \\
\text { Branco - MG (EFVM - Estrada de } \\
\text { Ferro Vitória a Minas) Jundiaí - SP } \\
\text { (ALLMP - América Latina Logística } \\
\text { Malha Paulista S.A.) Lapa - SP } \\
\text { (ALLMP - América Latina Logística } \\
\text { Malha Paulista S.A.) Perequê - SP } \\
\text { (ALLMP - América Latina Logística } \\
\text { Malha Paulista S.A.) Km } 64 \text { - RJ } \\
\text { (Supervia) Japerí - RJ (Supervia) }\end{array}$ & $\begin{array}{l}\text { Rio de Janeiro } \\
\text { (RJ), } \\
\text { Sepetiba (RJ) } \\
\text { e Santos (SP) }\end{array}$ & $\begin{array}{l}\text { Combustíveis, } \\
\text { Derivados do } \\
\text { Petróleo e } \\
\text { Álcool, } \\
\text { Carvão/Coque, } \\
\text { Cimento, } \\
\text { Granéis } \\
\text { Minerais, } \\
\text { Indústria } \\
\text { Cimenteira e } \\
\text { Construção Civil, } \\
\text { Indústria } \\
\text { Siderúrgica, } \\
\text { Minério de } \\
\text { Ferro, Carga } \\
\text { Geral (Não } \\
\text { Conteinerizada), } \\
\text { Conteiner } \\
\text { Adubos e } \\
\text { Fertilizantes, } \\
\text { Extração } \\
\text { Vegetal e } \\
\text { Celulose, } \\
\text { Açúcar, Milho, } \\
\text { Trigo, Soja e } \\
\text { Farelo de Soja }\end{array}$ \\
\hline TNLS & $\begin{array}{l}\text { Maranhão } \\
\text { Piauí, Ceará, } \\
\text { Rio Grande do } \\
\text { Norte, } \\
\text { Paraíba, } \\
\text { Pernambuco, } \\
\text { e Alagoas }\end{array}$ & 4.207 & $\begin{array}{c}1,00 / 1,60 \\
(18 \mathrm{~km}) \\
\mathrm{e} \\
1,00 \\
(4.189 \\
\mathrm{km})\end{array}$ & $\begin{array}{l}\text { Ramal Itaqui (Pombinho) - MA (EFC - } \\
\text { Estrada de Ferro Carajás) Propriá - } \\
\text { SE (FCA - Ferrovia Centro-Atlântica } \\
\text { S.A.) }\end{array}$ & $\begin{array}{l}\text { Maceió-Al } \\
\text { Pecém-CE } \\
\text { Itaqui-MA } \\
\text { Mucuripe-CE } \\
\text { Recife-PE } \\
\text { Natal-RN } \\
\text { Suape-PE } \\
\text { Cabedelo-PB }\end{array}$ & $\begin{array}{l}\text { Combustíveis, } \\
\text { Derivados do } \\
\text { Petróleo e Álcool } \\
\text { Carvão/Coque } \\
\text { Cimento, } \\
\text { Indústria } \\
\text { Cimenteira e } \\
\text { Construção Civil } \\
\text { Indústria } \\
\text { Siderúrgica } \\
\text { Minério de Ferro } \\
\text { Milho, Conteiner } \\
\text { Farinha de trigo }\end{array}$ \\
\hline
\end{tabular}

Fonte: ANTT, Acompanhamento das Concessões Ferroviárias. Relatório Anual do ano de 2013. (2014)

Org. LIMA, Ronei C. de, 2014.

Duas características ficam evidentes ao analisarmos o Quadro 8, a primeira é a concentração do sistema ferroviário, pois se territorializa na Região Concentrada (Sudeste e Sul), condição oriunda da inclusão da Rede Ferroviária Federal S.A. (RFFSA) no Programa Nacional de Desestatização, em 1992 (BRASIL, 2014d), que atendia principalmente a região Sudeste e pelo dinamismo econômico que demanda maior densidade de sistemas de engenharia. 
A segunda é o perfil da carga transportada, notadamente de commodities (minerais e vegetais). O que faz bastante sentido, pois se tratam de produtos de grande volume e peso e baixo valor agregado e por isto recomendado para o uso ferroviário articulado com hidrovias, pois como argumenta Castillo (2011, p. 341) “[...] as hidrovias e as ferrovias são, idealmente, mais adequadas para produtos de grande volume e de baixo valor agregado e a longas distâncias, com perda relativa de velocidade.”, o autor destaca que para distâncias de até 500 $\mathrm{km}$ o modal rodoviário é recomendado, de 500 a $1.200 \mathrm{~km}$ as ferrovias são mais adequadas e, finalmente, para distâncias superiores à $1.200 \mathrm{~km}$ as hidrovias são as mais indicadas.

De outro lado, verifica-se a presença de cargas acondicionadas em contêineres, que são mais utilizados para o transporte de produtos industriais mais elaborados e, segundo Contel (2004, p. 361) os fluxos gerados por este tipo de carga é bastante representativo do período técnico-científico-informacional. A participação do transporte ferroviário na movimentação deste tipo de cargas demonstra a reação do setor frente ao transporte rodoviário que pela flexibilidade do transporte ponto a ponto tinha a hegemonia nesse tipo de fluxo material.

Quanto ao transporte de passageiros, o mesmo ocorre somente na Estrada de Ferro Vitória Minas e na Estrada de Ferro Carajás, no total as duas ferrovias transportaram em 2013 um total de 1,19 milhão de passageiros. Este total apresenta uma redução em relação a 2012 com um total de 1,29 milhão. As empresas concessionárias não tem o foco no transporte de passageiros, mesmo havendo uma busca pela utilização do sistema ferroviário para fomentar a instalação de trens turísticos e histórico-culturais (BRASIL, 2014e), mas estes estariam restritos às áreas com potencial para essas atividades. Logo, a reprodução da vida da população a partir da formação de horizontalidades baseadas no transporte de passageiros não é uma prioridade para o setor.

Como a prioridade é o transporte de cargas, com destaque para a produção voltada à exportação, os empreendimentos em infraestrutura de transportes convergem em sistemas logísticos organizados para atender este objetivo. No caso dos investimentos privados, é próprio do setor buscar as melhores oportunidades, pois a lógica inerente às suas atividades é a reprodução do capital por meio do lucro.

No entanto, observa-se que o Estado também soma esforços para fomentar o setor corporativo por meio de investimentos diretos, pelo financiamento do setor privado e pelas concessões. As ações estatais no território buscam torná-lo eficiente e obediente aos interesses 
corporativos, que nesse caso é a busca por melhores condições de circulação de bens materiais - caso das commodities minerais e agrícolas - para reduzir custos e aumentar a competitividade interna.

Ao discutir a logística de exportação de soja em grãos de Mato Grosso, Pasin (2007, p. 205) faz um questionamento interessante:

No tocante à logística, a questão principal é se, ao orientar a ordenação do território para as vendas externas de um produto primário, implantando uma infra-estrutura voltada especificamente para esse fim, o estado não estaria criando uma dependência de trajetória de benefícios duvidosos no longo prazo.

A preocupação é relevante na medida em que é o Estado um dos principais agentes de ordenação do território, e devia fazê-lo de forma que os benefícios dessa ação não ficassem restritos aos interesses de uma parcela da sociedade, qual seja, a dos agentes privados cujo poder está baseado na força econômica que envolve os tomadores públicos de decisões importantes.

Esses agentes hegemônicos se organizam em associações, sindicatos, partidos políticos e tentam reorganizar o sistema de normas e regulações para facilitar suas ações no território. Daí a pressão sobre questões ambientais, indígenas, do direito ao acesso à terra, direitos trabalhistas e outros que impedem uma melhor operacionalidade corporativa.

É importante destacar que esses grupos defendem interesses internos, da elite local, e interesses externos, da elite global, pois a territorialização das ações não se dá sem a convergência de interesses. Mesmo a mais poderosa corporação depende das relações que se dão no âmbito do local para a realização de suas atividades.

Quanto à estruturação do território, como é o caso da criação e/ou ampliação do setor ferroviário nacional, esse aumento de capital fixo, com objetivo específico de favorecer os interesses hegemônicos, termina por favorecer o que Santos (2008a, p. 252) chama de “ampliação da demanda de rigidez". Por isto é importante o planejamento das ações cuja repercussão interfere na organização territorial, pois do contrário, pode-se comprometer o seu uso no futuro, já que o mesmo estará enrijecido previamente em virtude dos interesses da racionalidade econômica. 
Assim, a constituição do sistema ferroviário que se estendeu até o território matogrossense por meio da Ferronorte (hoje ALLMN), mantém essa lógica e é exemplar na consolidação da proposta de racionalização, sob a ótica corporativa, da dotação de sistema de engenharia voltada para a circulação.

O foco, no caso em tela, é a busca por uma intermodalidade de transporte com vistas à otimização do processo de fluidez, mas não uma fluidez de caráter horizontal, e sim uma fluidez corporativa e formadora de verticalidades específicas.

O período que vai da concessão da ferrovia em 1989, até o seu funcionamento em 2013, permite analisarmos a dinâmica do processo que envolveu os projetos públicos, os interesses privados e a participação social nas decisões que implicou em transformações importantes no território. A seguir trataremos da constituição e da efetivação do sistema ferroviário em Mato Grosso.

\subsubsection{A Ferrovia América Latina Logística Malha Norte (ALLMN)}

A gênese da ferrovia anteriormente chamada de Ferronorte e hoje denominada Ferrovia América Latina Logística Malha Norte (ALLMN) se dá com o edital de concorrência pública $\mathrm{n}^{\circ}$ 02/89, do Ministério dos Transportes para a Malha da Ferronorte, que foi lançado em 21 de fevereiro de 1989. E, em 27 de março de 1989, foi lançada a licitação, sob a modalidade de concorrência, para a concessão de obra e serviço público discriminada da seguinte forma:

Concessão para estabelecimento de um sistema de transporte ferroviário de carga, abrangendo a construção, operação, exploração e conservação de estradas de ferro entre Cuiabá (MT) e: a) Uberaba/Uberlândia (MG); b) Santa Fé do Sul (SP), na margem direita do Rio Paraná; C) Porto Velho (RO) e d) Santarém (PA). (BRASIL, 2014f).

Tratava-se, pois, de um projeto ambicioso que favoreceria a ligação das regiões Norte e Centro-Oeste com o Sudeste, permitindo uma maior integração entre essas regiões por meio 
de um modal adequado aos fluxos de mercadorias, principalmente das primeiras para a segunda.

A licitação exigia que as propostas contemplassem, mesmo que em médio prazo ou em longo prazo, práticas operacionais de intermodalidade de transportes, pois a ferrovia poderia servir de tronco principal a ser articulado com rodovias e hidrovias no percurso.

No contrato de concessão, vencido pela empresa Ferrovias Norte Brasil (Ferronorte S.A), fora previsto que no prazo de seis anos deveria estar pronto o trecho entre Cuiabá (MT) e Santa Fé do Sul (SP) e partindo deste trecho até Uberaba (MG) e Uberlândia (MG) constituindo a primeira etapa. A segunda etapa não teve prazo determinado, passando a depender do andamento da primeira etapa.

De fato era mais interessante fazer a ligação da porção dos territórios de Mato Grosso e Mato Grosso do Sul, já consolidados àquela altura com o agronegócio, com São Paulo, principal fornecedor de insumos e grande mercado interno.

$\mathrm{Na}$ operacionalização dos investimentos estava previsto o apoio do Estado, por meio de capitais da SUDAM, por meio do Fundo de Investimento da Amazônia (FINAM), com recursos para a execução das obras. O Estado buscava estimular a iniciativa privada, pois a prestação do serviço público de transporte ferroviário, efetuado pelo poder público, não conseguia acompanhar as demandas que surgiam. Além dos recursos públicos, toda uma arquitetura financeira seria direcionada para capitalizar e permitir a execução da obra, como exemplos são citados: recursos bancários, antecipação de fretes, conversão da dívida externa brasileira e de usuários, cooperativas e órgãos governamentais beneficiados com o empreendimento. (BRASIL, 2014f).

A partir da assinatura do contrato de concessão, ocorrido em 19 de maio de 1989, o mesmo passou a receber constantes aditivos que buscavam adequar as exigências contratuais com a realidade de execução do projeto e da obra. O Quadro 9, apresenta uma síntese desses aditivos. 


\section{Quadro 9 - Aditivos do contrato de concessão da Ferrovia ALLMN}

\begin{tabular}{|c|c|c|}
\hline Aditivo & Data & Conteúdo \\
\hline $1^{\circ}$ & $05 / 1991$ & $\begin{array}{l}\text { - Prorrogação de } 12 \text { meses (a partir de 05/09/90) do prazo de elaboração do projeto } \\
\text { básico da primeira etapa }\end{array}$ \\
\hline $2^{0}$ & $01 / 04 / 1992$ & $\begin{array}{l}\text { - Prorrogação de } 12 \text { meses (a partir de 05/09/91) do prazo de elaboração do projeto } \\
\text { básico da primeira etapa }\end{array}$ \\
\hline 3음 & 09/07/1992 & $\begin{array}{l}\text { - Revogado o Inciso V da Cláusula Segunda do contrato de concessão; } \\
\text { - Novo texto para a cláusula nona - da Rescisão indicando que o grave inadimplemento } \\
\text { da concessionária implica na Rescisão; caso ocorra necessita de justificativa da } \\
\text { concessionária que será analisada }\end{array}$ \\
\hline $4^{\circ}$ & $12 / 11 / 1992$ & $\begin{array}{l}\text { - Prorrogado até } 05 / 12 / 1993 \text { o prazo para elaboração do projeto básico da } 1^{\text {a }} \text { etapa; } \\
\text { - O prazo para a conclusão da } 1^{\text {a }} \text { etapa passa a ser de } 57 \text { meses a partir da data de } \\
\text { aprovação do projeto básico pelo Ministério dos Transportes }\end{array}$ \\
\hline $5^{0}$ & $09 / 08 / 1997$ & $\begin{array}{l}\text { - Revoga a cláusula que estipulava } 57 \text { meses para execução da } 1^{\text {a }} \text { etapa da obra e } \\
\text { determina o novo prazo de } 30 \text { meses para execução do trecho entre Aparecida do } \\
\text { Taboado (MS) (margem direita do Rio Paraná) e Alto Taquari (MT) com } 400 \mathrm{~km} \text { a partir } \\
\text { do término da obra da ponte Rodoferroviária sobre o rio Paraná; } \\
\text { - Os demais trechos aguardam nova data para execução }\end{array}$ \\
\hline $6^{\circ}$ & $31 / 12 / 1997$ & $\begin{array}{l}\text { - Vem restabelecer o Inciso } V \text { da Cláusula Segunda que permite que a concessionária } \\
\text { dê em garantia os direitos emergentes da concessão, a fim de levantar financiamentos } \\
\text { para a execução das obras, desde que a ação não inviabilize a prestação de serviços da } \\
\text { concessionária e que tenha a prévia autorização da União }\end{array}$ \\
\hline $7^{0}$ & $31 / 12 / 1998$ & $\begin{array}{l}\text { - Altera o contrato de concessão quanto ao trecho que passa a ser entre: Cuiabá (MT) e: } \\
\text { a) Uberaba (MG) e Uberlândia (MG); Aparecida do Taboado (MS) (margem direita do rio } \\
\text { Paraná); c) Porto Velho (RO) e d) Santarém (PA); } \\
\text { - Quanto às etapas temos: a primeira com extensão entre } 1.600 \mathrm{~km} \text { e } 1.700 \mathrm{~km} \text {, cujos } \\
\text { tramos principais: Cuiabá (MT) e Aparecida do Taboado (MS) e outro que partirá de um } \\
\text { ponto qualquer do primeiro, indo até Uberaba (MG) e Uberlândia (MG). A segunda etapa } \\
\text { se refere às ligações que se articulam com as hidrovias da bacia amazônica: Cuiabá- } \\
\text { Porto Velho (RO), no rio Madeira e Cuiabá-Santarém (PA) no rio Tapajós }\end{array}$ \\
\hline $8^{\circ}$ & $29 / 04 / 2008$ & $\begin{array}{l}\text { Tendo em vista a inclusão no PAC (Decreto no } 6.025 \text {, de } 22 \text { de janeiro de 2007) do } \\
\text { trecho da Ferronorte até Rondonópolis, com prazo estipulado de conclusão até 2010; a } \\
\text { possibilidade de subcontratação por parte da concessionária e pela apresentação por } \\
\text { parte desta de Projeto Conceitual demonstrando a viabilidade econômico-financeira até } \\
\text { Rondonópolis-MT; foi definido o prazo de construção do trecho entre Alto Araguaia (MT) } \\
\text { a Rondonópolis (MT) e a autorização para a construção por terceiros interessados sob a } \\
\text { responsabilidade da concessionária: } \\
\text { - Data limite de operação comercial do trecho ferroviário Alto Araguaia (MT) a } \\
\text { Rondonópolis (MT), com } 262 \mathrm{~km} \text {, para } 31 \text { de dezembro de } 2010 ; \\
\text { - Para os terceiros interessados o pagamento se dará no máximo em } 25 \text { anos a contar } \\
\text { da data da entrada em operação do novo trecho, sob a supervisão da ANTT; } \\
\text { - Caso o prazo não seja cumprido, a concessionária poderá, a cargo da União, perder a } \\
\text { concessão da ferrovia }\end{array}$ \\
\hline $9^{\circ}$ & $15 / 10 / 2010$ & $\begin{array}{l}\text { Tendo em vista o não cumprimento do prazo estabelecido no } 8^{\circ} \text { aditivo, a União retirou } \\
\text { a concessão da ALLMN compreendendo os seguintes trechos: a) Cuiabá (MT) e } \\
\text { Uberaba (MG) e Uberlândia (MG), b) Cuiabá e Rondonópolis (MT) , c) Cuiabá e Porto } \\
\text { Velho (RO) e d) Cuiabá e Santarém (PA); } \\
\text { - Permanece a concessão do trecho entre Aparecida do Taboado (MS) e Rondonópolis } \\
\text { (MT); } \\
\text { - O novo prazo para o término da obra é de } 24 \text { meses a partir de } 31 \text { de dezembro de } \\
2010, \text { sendo que este poderá ser revisto caso haja problemas de atraso referente às } \\
\text { liberações de licenças ambientais, desde que a concessionário não seja a responsável } \\
\text { pelos problemas ocorridos. }\end{array}$ \\
\hline
\end{tabular}

As reiteradas alterações no contrato inicial é fruto de causas diversas, pois no período tivemos no Brasil importantes mudanças em virtude da crise fiscal, da inflação, da dívida externa, mudanças políticas importantes (com a abertura da economia no governo Collor), a estabilização econômica com o Plano Real, e por conta de conjunturas internacionais, principalmente no que tange a crise de mercado da soja. 
Nesse sentido Souza (2011, p. 414) faz o seguinte relato:

A Ferronorte teve suas obras iniciadas em 1992, mas devido a problemas financeiros (provocados pela crise da soja e pela queda dos preços no mercado exterior, assim como pelo encolhimento nos financiamentos e pela alta dos juros), teve suas obras paralisadas, tendo sido retomadas somente em maio de 1997, contando inclusive com nova composição societária, incorporado investimentos estrangeiros e fundos de pensão.

É possível perceber esse interstício de tempo na execução das obras no Quadro 9, anteriormente apresentado, quando constatamos alterações do $4^{\circ}$ para o $5^{\circ}$ aditivo do contrato de concessão. O projeto inicial da ferrovia foi proposto pelo Grupo Itamarati, mas a crise do grupo de Olacyr de Moraes, conhecido até então como o Rei da Soja, exigiu a presença de outras fontes de capital, caso dos fundos de pensão nacionais, bem como da participação de investimentos estrangeiros.

A participação do Estado no controle da concessão foi sistemática, e a cada aditivo oportunizava à concessionária condições de reorganizar-se para realizar a obra. Porém os prazos eram sucessivamente vencidos sem que as ações acordadas fossem efetivadas. No percurso da construção da ferrovia, outras estratégias foram sendo elaboradas pelo Estado com vistas a não retomar imediatamente os trechos concedidos. De forma tímida a ferrovia tomava corpo a partir da ponte Rodoferroviária que foi construída sobre o rio Paraná na divisa entre São Paulo e Mato Grosso do Sul.

Uma das estratégias foi a inclusão da Ferronorte, no ano de 1996, no programa Brasil em Ação, fato que permitiu a conclusão do trecho entre a ponte Rodoferroviária e o terminal de Inocência em Mato Grosso do Sul no ano de 1998. E em maio de 1999 mais um trecho foi inaugurado, fazendo a ligação de Inocência-MS à Chapadão do Sul-MS (SOUZA, 2011).

De acordo com a Associação Nacional dos Transportadores Ferroviários (ANTF, 2014) em junho de 1998 a Ferronorte passou a ser controlada pela Ferronorte Participações S.A. (Ferropasa) detentora dos direitos de concessão da Ferronorte e da Novoeste. A Ferropasa, ao se constituir como principal acionista do consórcio Ferrovias, arremata em leilão a antiga Malha Paulista da RFFSA (antiga FEPASA) constituindo a Ferrovias Bandeirantes S.A. (Ferroban). Em seguida temos a criação da holding Brasil Ferrovias, em 2002, que passou a controlar três ferrovias: Ferronorte, Novoeste e Ferroban. Em 2006, 
finalmente temos a América Latina Logística assumindo as ferrovias e operando a Ferronorte sob a denominação de América Latina Logística Malha Norte (ALLMN).

É relevante o fato da constituição da Ferropasa e da Brasil Ferrovias, num primeiro momento, pois cria a possibilidade de controle do transporte ferroviário de Mato Grosso do Sul e de Mato Grosso, dois grandes produtores de grãos. No caso de Mato Grosso do Sul o interesse também era voltado para o setor mineral. Com a ligação da Ferronorte e Novoeste à Ferroban, o acesso à malha paulista permitia a ligação com o porto de Santos, principal terminal de saída de produtos para o exterior.

A ALL passa a controlar um conjunto de ferrovias, denominadas de ALL Malha Norte S.A, ALL Malha Oeste S.A, ALL Malha Paulista S.A e ALL Malha Sul S.A., se constituindo como o maior operador ferroviário com ações em estados da região Sul, Sudeste e CentroOeste. Em Mato Grosso, a ALLMN iniciou suas atividades em Alto Taquari em 2000 e em Alto Araguaia em 2002. O terminal de Itiquira, em parceria com a Seara, foi inaugurado em 2012. Já o Complexo Intermodal de Rondonópolis (CIR), maior terminal ferroviário da ALL iniciou suas operações na cidade em setembro de 2013.

No campo da realidade, Mato Grosso conta com esse sistema de transporte ferroviário localizado na sua porção mais ao Sul, posição estratégica, pois fica mais próximo do centro econômico e financeiro, representado pela Região Concentrada. Já no campo das possibilidades, as perspectivas se voltam para um novo eixo ferroviário, representado de forma menos abstrata pela Ferrovia de Integração do Centro-Oeste (FICO) cuja materialização depende, entre outros fatores, da constituição das regras do edital de concessão, pelo Estado, para ir a leilão.

E, no campo das conjecturas, cogitou-se a proposta de uma ferrovia que margearia a BR-163, a partir de Lucas do Rio Verde, onde faria conexão com a FICO em direção ao porto de Miritituba no Pará, ferrovia que seria denominada de Ferrogrão (RIBEIRO; PUPO, 2014). A proposta, apesar de estar em consonância com a lógica de inversão da logística de transporte em direção ao Norte, resvala na concorrência do trecho em estudo de concessão da BR-163 de Sinop (MT) até o porto de Miritituba (PA), mas é incentivada pelos produtores e tradings do agronegócio e já existem estudos de viabilidade técnica em curso para parte deste trecho, compreendendo Sinop-MT à Itaituba/Miritituba-PA. 
Quanto aos terminais ferroviários em funcionamento em Mato Grosso, o Quadro 10, apresenta como estes estão estruturados do ponto de vista operacional.

Quadro 10 - Características dos terminais da ALLMN em Mato Grosso

\begin{tabular}{|c|c|c|c|c|c|}
\hline Local & $\begin{array}{c}\text { Tipo } \\
\text { de } \\
\text { terminal }\end{array}$ & $\begin{array}{l}\text { Principais produtos } \\
\text { movimentados }\end{array}$ & $\begin{array}{c}\text { Capacidade } \\
\text { de } \\
\text { descarga }\end{array}$ & $\begin{array}{c}\text { Capacidade } \\
\text { de } \\
\text { carregamento }\end{array}$ & $\begin{array}{l}\text { Distância } \\
\text { do Porto } \\
\text { de Santos }\end{array}$ \\
\hline Alto Taquari & $\begin{array}{l}\text { Granéis } \\
\text { (ALL, BR } \\
\text { Distribuidora } \\
\text { ) }\end{array}$ & $\begin{array}{l}\text { Soja, farelos e milho } \\
\text { (para o mercado } \\
\text { interno) e para o } \\
\text { mercado externo via } \\
\text { Porto de Santos; } \\
\text { Recepção de } \\
\text { fertilizantes, } \\
\text { principalmente do } \\
\text { exterior via Porto de } \\
\text { Santos. }\end{array}$ & $\begin{array}{l}384.424 \\
\text { TU/mês }\end{array}$ & $\begin{array}{l}389.491 \\
\text { TU/mês }\end{array}$ & $\begin{array}{l}1.303,43 \\
\mathrm{~km}\end{array}$ \\
\hline Alto Araguaia & $\begin{array}{l}\text { Granéis } \\
\text { (ALL, LDC, } \\
\text { Mosaic, } \\
\text { Galvani e } \\
\text { Bunge) }\end{array}$ & $\begin{array}{l}\text { Soja, farelos e milho } \\
\text { (para o mercado } \\
\text { interno) e para o } \\
\text { mercado externo via } \\
\text { Porto de Santos; } \\
\text { Recepção de } \\
\text { fertilizantes, } \\
\text { principalmente do } \\
\text { exterior via Porto de } \\
\text { Santos. }\end{array}$ & $\begin{array}{l}333.518 \\
\text { TU/mês }\end{array}$ & $\begin{array}{l}652,573 \\
\text { TU/mês }\end{array}$ & $\begin{array}{c}1.401,08 \\
\mathrm{~km}\end{array}$ \\
\hline Itiquira & $\begin{array}{l}\text { Granéis } \\
\text { (Seara) }\end{array}$ & $\begin{array}{l}\text { Soja e milho para o } \\
\text { mercado externo via } \\
\text { portos de Santos, } \\
\text { Paranaguá e São } \\
\text { Francisco do Sul }\end{array}$ & $\begin{array}{l}576.000 \\
\text { TU/mês }\end{array}$ & $\begin{array}{l}576.000 \\
\text { TU/mês }\end{array}$ & $\begin{array}{c}1.521,08 \\
\mathrm{~km}\end{array}$ \\
\hline Rondonópolis & $\begin{array}{l}\text { Granéis e } \\
\text { contêineres } \\
\text { (ALL, Brado, } \\
\text { Noble, } \\
\text { Raizen) }\end{array}$ & $\begin{array}{l}\text { Soja, farelos e milho } \\
\text { (para o mercado } \\
\text { interno) e para o } \\
\text { exterior via Porto de } \\
\text { Santos; } \\
\text { Recepção de } \\
\text { fertilizantes, } \\
\text { principalmente do } \\
\text { exterior via Porto de } \\
\text { Santos, e } \\
\text { combustíveis. }\end{array}$ & $\begin{array}{l}3.240 .000 \\
\text { TU/mês }\end{array}$ & $\begin{array}{c}3.600 .000 \\
\text { TU/mês }\end{array}$ & $\begin{array}{c}1.661,08 \\
\mathrm{~km}\end{array}$ \\
\hline
\end{tabular}

Fonte: Trabalho de campo (junho e julho) de 2014

Em relação à gestão dos terminais, três são operados diretamente pela ALL - os terminais de Rondonópolis, Alto Araguaia e Alto Taquari -, e o terminal de Itiquira é operado pela Seara. Este último opera diretamente com granéis sólidos (grãos de soja e milho), pois a empresa já fazia a originação dessas commodities em Mato Grosso, mas não processa as mesmas nas suas dependências, como ocorre em Rondonópolis (Noble) e Alto Araguaia (Louis Dreyfus). 
Quanto ao funcionamento a Figura 8, apresenta as dinâmicas dos fluxos de grãos e farelo de soja, aqui considerados como fluxos materiais, e um esboço das ações de comando das operações, denominadas de fluxos imateriais, nas instalações do maior terminal da ALL, localizado em Rondonópolis. 
Figura 8 - Fluxos materiais e imateriais entre as tradings $e$ a ALLMN

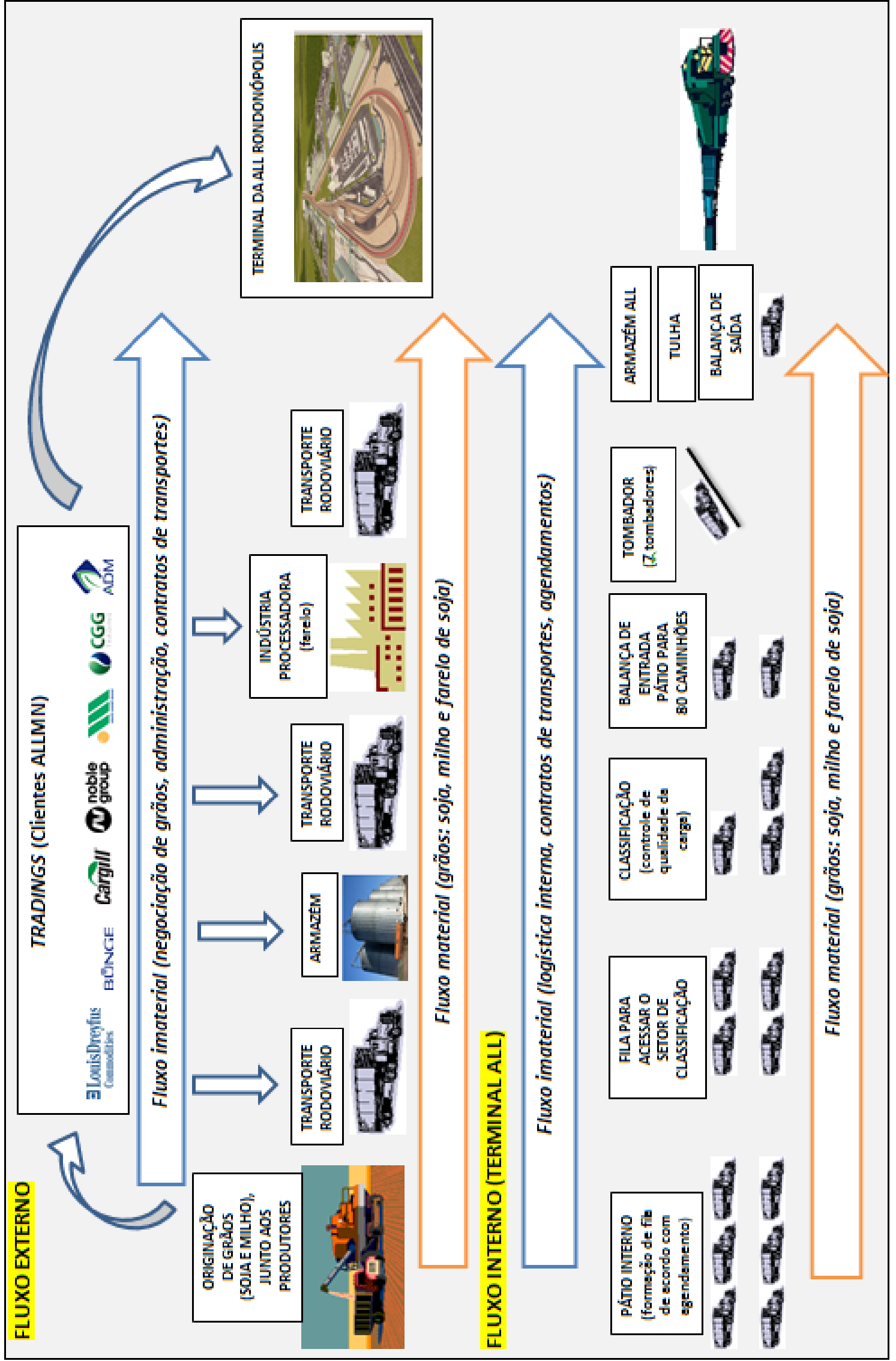

Fonte: LIMA, Ronei C. de (2014) - Trabalho de campo efetuado em 02 de julho de 2014. 
A concepção de fluxos materiais e imateriais é importante na medida em que permite compreender a complexidade dos processos inerentes à circulação que ocorre no território mato-grossense, mas que possui conexões em variados níveis, com ênfase para o nível global, tendo em vista o caráter extrovertido das operações efetivadas.

Silveira (2011a, p. 43) discutindo os fluxos como concepção importante no estudo do que ele denomina de "Geografia da Circulação, Transportes e Logística", propõe para o termo, de forma simplificada - mas consciente da necessidade de uma visão não fragmentária e, portanto, baseada em uma totalidade concreta -, que este se refira à "[...] quantidade de pessoas, de bens, de informações, entre outros, medida em uma linha de comunicação. Pode ser material e imaterial.".

Já Contel (2004, p. 357), tratando dos sistemas de movimento do território, entende o mesmo como sendo "[...] o conjunto indissociável de sistemas de engenharia (fixos) e de sistemas de fluxos (materiais e imateriais) que respondem pela solidariedade geográfica entre os lugares.", o autor chama a atenção para o fato da maior intensidade da divisão territorial do trabalho implicar na necessidade das abordagens acerca do fenômeno de movimentação no território.

Também entendemos ser lícito apropriar a este processo de criação de fluxos apresentados na Figura 8, a assertiva de Raffestin (1993, p. 200) quando argumenta que "A circulação e a comunicação são as duas faces da mobilidade.”, e, por possuírem um caráter de complementaridade, permeiam as estratégias desencadeadas pelos agentes cujo objetivo seja o domínio efetivo de pontos e superfícies.

Nesse sentido, é pertinente a colocação de Blanco e Rodrigues (2011, p. 4) que ao tratar das redes de circulação no território informam a existência de duas redes fundamentais para o processo logístico, quais sejam as redes de transporte e de telecomunicações. O autor pontua que existe uma articulação entre redes diversas na atual circulação, o que favorece por sua vez o movimento intermodal tendo em vista ser este movimento planejado e monitorado por sistemas de comunicações complexos.

Esta ação imprescindível para a circulação se dá então pela gestão e controle das distâncias, ações que os atores desencadeiam para dominar as superfícies e os pontos através dos meios técnicos e operacionais disponíveis. Temos então uma condição de jogo de poderes entre os diversos agentes envolvidos na ação, confirmando a tese que propõe Stourdzé (s/d) de 
que "A circulação imprime a sua ordem. A circulação é a imagem do poder." (RAFFESTIN, 1993, p. 202).

A relação entre as tradings com os produtores e com as empresas prestadoras do serviço de transportes evidencia esta condição de estratégias baseadas na condição de circulação (dos bens materiais) e da comunicação (elementos de comando em diversos níveis) cujo conjunto realiza o processo como um todo, qual seja, otimizar a movimentação das commodities.

É possível verificar, na Figura 9, a semelhança estrutural de um escopo mais generalizado do processo, denominado de logística empresarial, com a logística de transportes efetuada entre as tradings e a ALLMN. Este fato se dá porque comunga um mesmo objetivo que é a movimentação de mercadorias dentro de padrões de racionalidade estabelecidos, cuja meta é a realização do processo de produção em sua plenitude (produção-distribuiçãocirculação-consumo), podendo ser relacionada com o que Silveira (2011a, p. 60) chamou de "logística organizacional".

Ballou (2012, p. 35) entende que houve uma evolução da logística empresarial, quando esta num contexto mais amplo passa a apresentar uma maior integração após a década de 1970. E assim, a logística empresarial começa a ser "[...] entendida como a integração tanto da administração de materiais como da distribuição física.", tornando o processo mais complexo.

\section{Figura 9 - Escopo da logística empresarial}

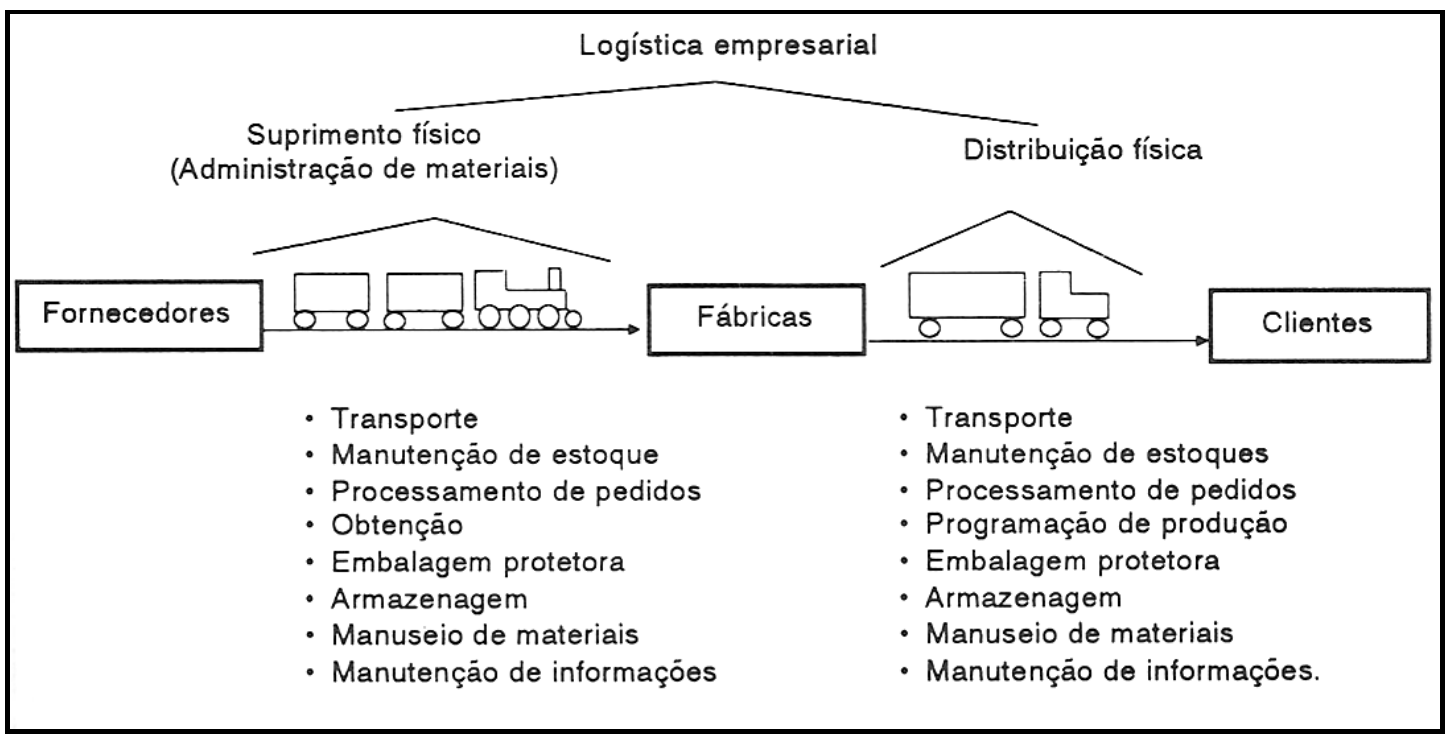

Fonte: BALLOU, R. H. (2012) 
Em decorrência da implantação dos terminais ferroviários em Mato Grosso - que proporcionou a intermodalidade no interior do seu território e possibilitou uma evolução da logística empresarial (logística organizacional) -, temos rebatimentos importantes no território, pois houve o fortalecimento da articulação das áreas do entorno com os diversos mercados.

Assim, a construção dos terminais nos municípios citados proporcionou um incremento considerável nas economias locais, em virtude dos investimentos efetivados por diversas empresas com operações diretas nos terminais e pelos serviços de suporte demandados. Os Gráficos 4 e 5, mostram a evolução do PIB dos municípios de Alto Taquari e de Alto Araguaia, onde a ALLMN possui terminais próprios e de terceiros funcionando desde 2000 e 2002, respectivamente.

\section{Gráfico 4 - Evolução do PIB de Alto Taquari de 1999 a 2012}

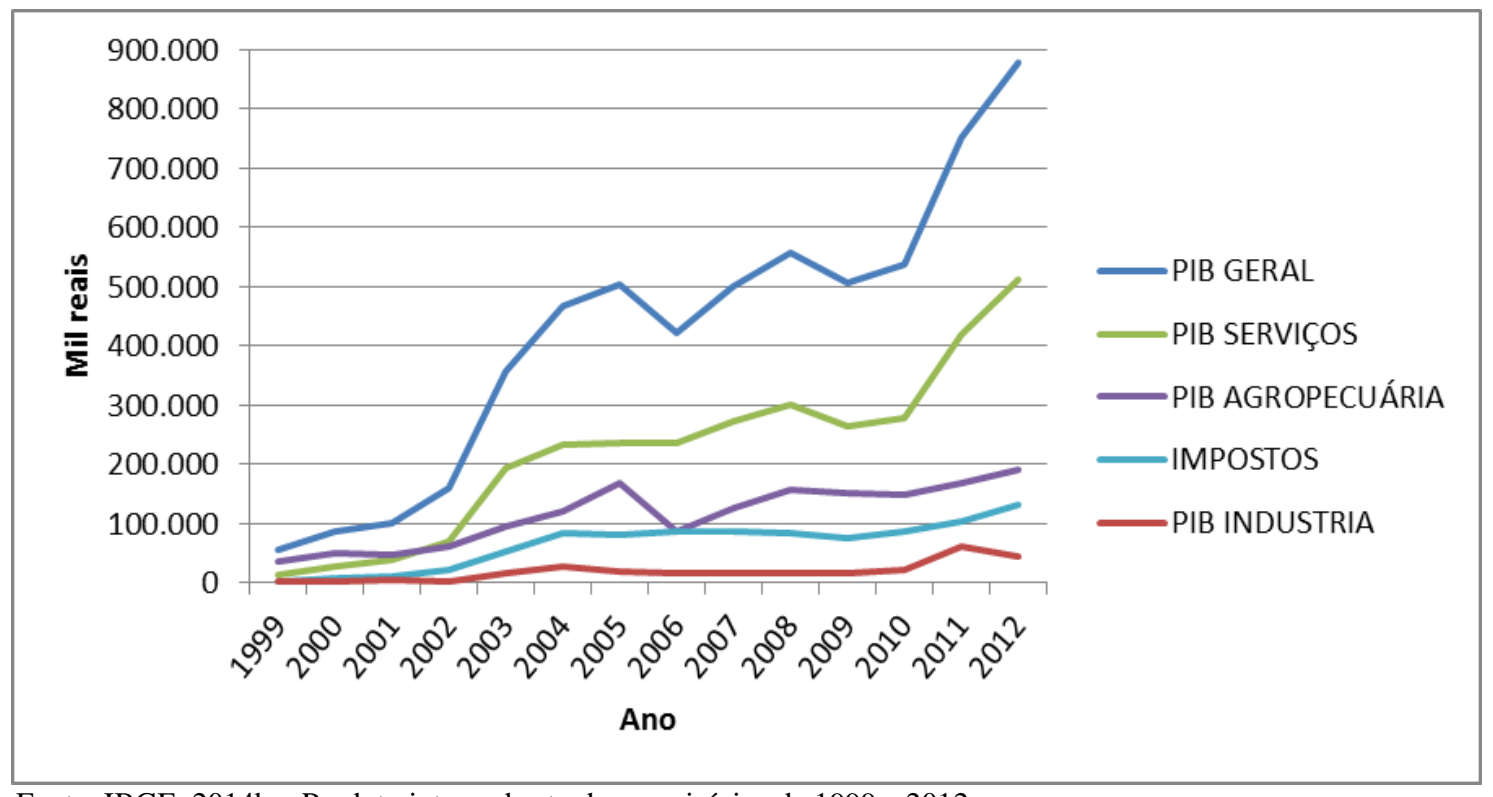

Fonte: IBGE, 2014b - Produto interno bruto dos municípios de 1999 a 2012 


\section{Gráfico 5 - Evolução do PIB de Alto Araguaia de 1999 a 2012}

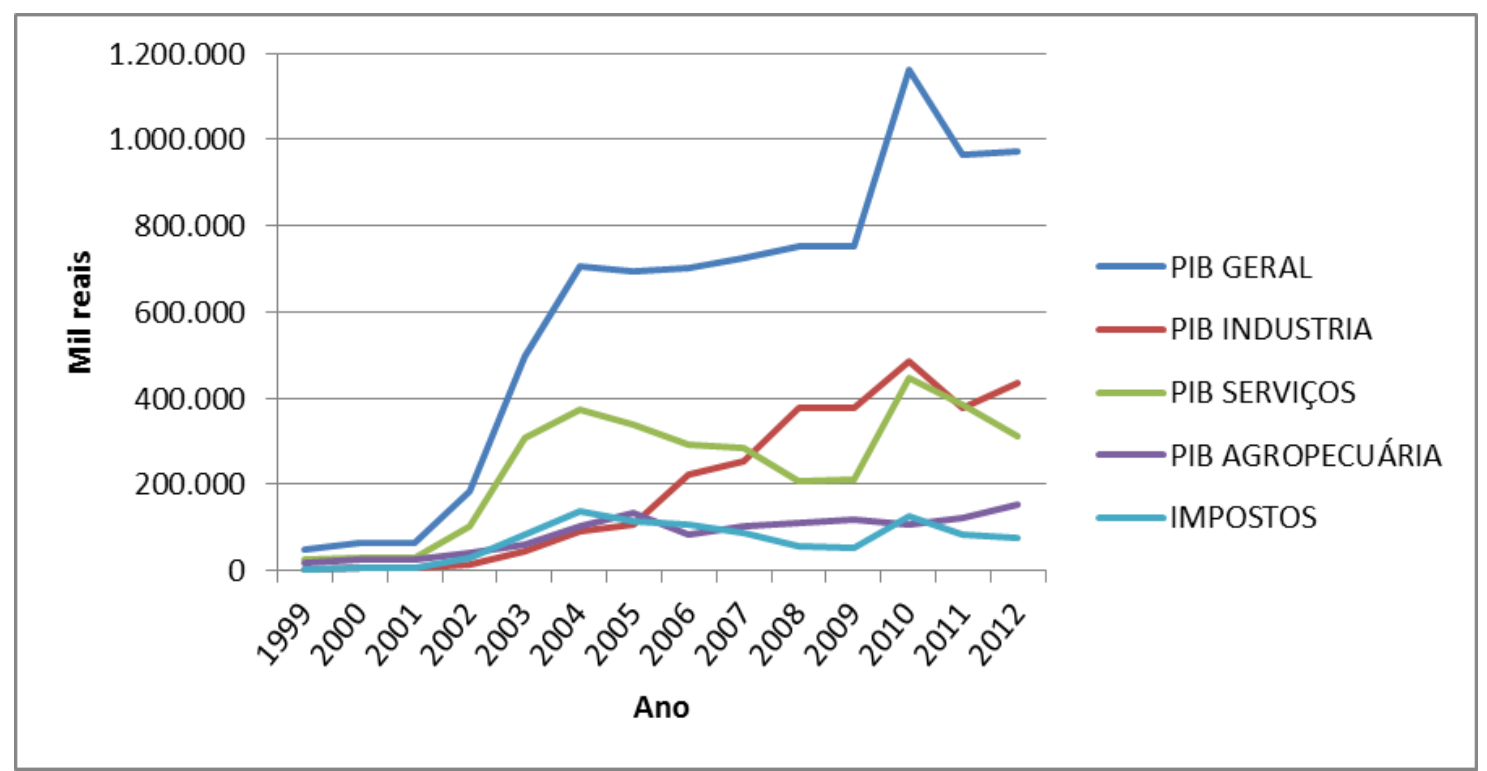

Fonte: IBGE, 2014b - Produto interno bruto dos municípios de 1999 a 2012

Um fato, no entanto, começa a preocupar os líderes políticos dos municípios cujos terminais apresentam redução significativa das operações com o início das atividades em Rondonópolis. Como um efeito em cadeia, o aumento sucessivo dos embarques e desembarques em Rondonópolis provocou um esvaziamento dessas operações em Alto Araguaia e Alto Taquari. Reuniões entre autoridades municipais e estaduais buscam como alternativas mudanças na legislação para reduzir impostos e, assim, atrair empresas interessadas em utilizar os terminais que começam a ficar ociosos, ou buscar a terceirização das instalações para outras empresas, além de criar um distrito industrial junto ao terminal de Alto Taquari.

O movimento do capital, na busca pela sua reprodução ampliada, interfere diretamente nos territórios onde se instala, ensejando vantagens e demonstrando pouco compromisso com as comunidades afetadas pela sua dinâmica. Pois, como argumentam Firkowski e Sposito (2008, p. 65-66) os ajustes das empresas provocam tendências contraditórias na sua relação com os territórios, já que a lógica financeira prevalece sobre a lógica industrial, originando um “[...] comportamento mais distanciado em relação aos territórios.”.

Assim, as possibilidades que se apresentavam, inicialmente encorajadoras de investimentos econômicos de várias ordens, incitava na sociedade local a perspectiva de perenidade nas condições até então favoráveis, porém, as estratégias empresariais não se 
prestam à manutenção de investimentos que não sejam voltados para a contínua acumulação de capital.

No entanto, mesmo no encalço dos períodos mais dinâmicos, com a instalação de empresas, o surgimento de vagas de emprego e os acréscimos de capital que circulava nas cidades do entorno dos empreendimentos, a precarização da reprodução social se concretizava - caso explícito de Alto Araguaia -, com as instalações insalubres que servem de moradia e ambiente laboral para um grupo de pessoas que se amontoam irregularmente nas margens da BR-364. As pessoas que ali habitam buscam, mesmo que de forma marginal, participar do milagre econômico que outrora parecia ser mais duradouro e que agora agoniza pelas mudanças de interesses dos agentes hegemônicos que dirigem as empresas e que parecem, de qualquer forma, dirigir os destinos dessa parcela da sociedade.

No caso de Alto Araguaia, é possível observar um efeito direto da instalação do terminal ferroviário, qual seja, o acréscimo considerável da produção industrial, outrora incipiente, que se tornou o principal setor econômico do município. Apesar do viés de queda do PIB industrial, já observado em 2011 e de estabilidade em 2012, confirma-se a estreita relação entre a instalação de sistemas de engenharia de transportes e a instalação de atividades mais elaboradas e dotadas de maior densidade técnica, caso do setor industrial.

Pode-se dizer que a instalação de tais fixos - caso dos terminais ferroviários em consórcio com o rodoviário, caracterizando uma intermodalidade -, cria uma força centrípeta na atração de mais fixos. No entanto, como o movimento é constante, a criação de novos fixos em outras áreas pode significar o ocaso de áreas até então luminosas sob a ótica capitalista. Nesse sentido, abordaremos a seguir a relação existente entre a logística de transportes instalada e a presença de agroindústrias em Mato Grosso.

\subsection{A RELAÇÃo dA LOGÍSTICA COM A AGROINDÚSTRIA EM MATO GROSSO E A LÓGICA DA CONCENTRAÇÃO AGROINDUSTRIAL}

A concentração industrial no estado de Mato Grosso apresenta uma relação direta com a existência seletiva de infraestruturas de transportes, energia e de comunicações que estão 
dispostas de maneira diferenciada pelo território. Os tipos de indústrias também se condicionam às matérias-primas, daí a emergência das agroindústrias, que na esteira da produção, principalmente de grãos e carnes, se localizam nas áreas próximas às principais regiões produtoras e, principalmente, naquelas dotadas de sistemas de engenharia demandados pelo setor produtivo.

Santos e Silveira (2004, p. 107) chamam a atenção para a região Centro-Oeste já que esta se caracteriza no quadro industrial por abrigar várias "etapas da cadeia produtiva das mais poderosas agroindústrias sulistas e evidenciando também a alta concentração de capitais e a automação dos processos produtivos.”.

O quadro atual é reconfigurado com a ascendência das principais empresas do agronegócio global, como a Cargill, ADM, Bunge e Louis Dreyfus Commodities (LDC), que estão instaladas estrategicamente nas principais áreas de produção da região, ficando às empresas nacionais uma função de complementaridade ou hegemonia compartilhada (caso do grupo Amaggi).

No entanto, no setor de carnes grupos nacionais como BRF e JBS Friboi controlam parcelas significativas dos seus respectivos segmentos de mercado (carnes de suínos, de aves e de bovinos), inclusive com participação em escala global, caso do JBS Friboi.

Quanto às tradings do agronegócio, em Mato Grosso essas empresas se organizam em diversas atividades: financiamento da produção, originação de grãos, armazenamento, insumos (fertilizantes, sementes), processamento, exportação, cujo conjunto permite um controle notável do setor produtivo, pois canaliza, por meio de suas estratégias corporativas, a quase totalidade do que é produzido para os fins extrovertidos que caracteriza o setor, fortalecendo e mantendo a lógica dos corredores de exportação.

As agroindústrias instaladas no estado se concentram principalmente nos setores de processamento de grãos (óleo refinado, óleo degomado, farelos, rações e biodiesel) e de fertilizantes. Outros produtos demandados pelo agronegócio (maquinários e agrotóxicos) são produzidos fora do estado. Um exemplo é a fábrica da Nortox, instalada em Rondonópolis, cuja produção atual é realizada no Paraná e as instalações em Mato Grosso estão sendo utilizadas apenas como depósito.

A pouca diversificação reflete os interesses específicos das empresas instaladas, qual seja, aproveitar o potencial da produção agropecuária e aliá-lo aos benefícios fiscais 
disponibilizados por programas especiais e ao financiamento público (Fundo Constitucional de Financiamento do Centro-Oeste - FCO e BNDES). No conjunto, essas condicionantes permite uma reprodução do capital, pois parte do ônus é assumido pelo Estado por meio da renúncia fiscal e pelos baixos juros praticados pelos financiamentos concedidos.

\subsubsection{A questão fiscal como estratégia de atração}

No conjunto de estratégias voltadas para a atração do setor corporativo, o Estado, no seu papel de planejador e gestor do território - mesmo que em consonância com os setores privados dos quais é solidário -, disponibiliza vantagens para criar um quadro favorável para a realização capitalista. Assim, além de vantagens quanto a infraestrutura, as vantagens normativas têm se apresentado como alternativa bastante comum no atual contexto.

No que tange à questão dos incentivos fiscais e da renúncia fiscal, estas refletem uma realidade de disputas normativas em escalas diversas (local, regional, nacional e global), a chamada guerra fiscal, que constitui uma estratégia da guerra dos lugares.

Essa guerra é promotora de uma corrida por investimentos que em muitos casos não redundam em retorno financeiro direto e/ou indireto como pretendido pelos concessores, podendo, em alguns casos, tornar-se um mecanismo puramente mercantil-financeiro de interesse direto de "trading companies" como apontam Macedo e Angelis (2013, p. 202) quando analisam a guerra fiscal dos portos brasileiros em relação às importações, formatando um quadro em que o setor produtivo passa a sofrer intensa pressão.

Para o caso dos estados brasileiros que não possuem portos articulados com o circuito importador, os autores chamam a atenção para a utilização por parte desses estados das Estações Aduaneiras do Interior (EADI) também denominadas como portos secos.

Segundo Santos (2008a, p. 247-248) a distinção entre os lugares poderia ser medida pela capacidade de cada um de disponibilizar aos investimentos a rentabilidade esperada, sendo que: 
[...] Essa rentabilidade é maior ou menor, em virtude das condições locais de ordem técnica (equipamentos, infra-estrutura, acessibilidade) e organizacional (leis locais, impostos, relações trabalhistas, tradição laboral). Essa eficácia mercantil não é um dado absoluto do lugar, mas se refere a um determinado produto e não a um produto qualquer.

A rentabilidade surge também da redução sistemática de custos, logo a oferta de isenções fiscais serve como estímulo aos investimentos, pois diferencia os lugares. No caso aqui analisado, como as isenções são ofertadas pelo governo estadual, ocorre uma concorrência inter-regional entre os entes da federação na disputa por investimentos, que hoje se diversificam cada vez mais. Nesse sentido, Braga e Castillo (2013, p. 254) argumentam que:

[...] a guerra dos lugares, incluindo a guerra fiscal, isto é, a construção de circunstâncias vantajosas para a localização e o desempenho das empresas, não se limita às atividades industriais, mas se estende às atividades da esfera da circulação, ou melhor, da logística.

As grandes corporações e mesmo empresas de menor porte já pautam em suas estratégias operacionais os incentivos fiscais, que disseminados nacionalmente, terminam por criar certa equivalência entre os territórios, cabendo ao setor privado, interessado em investir, analisar outros aspectos de vantagens oferecidas aumentando a pressão sobre os lugares.

Como paradoxo, temos a seguinte situação: com a constante concessão de incentivos fiscais, que converge em renúncia fiscal, ocorre significativa redução da arrecadação de estados e municípios e com isto os investimentos ficam comprometidos. No discurso dos dirigentes públicos, os incentivos fiscais disponibilizados às empresas estão normalmente ancorados nas necessidades de geração de empregos e crescimento econômico de setores específicos ou de áreas prioritárias. Essa é a atual realidade do estado de Mato Grosso frente ao quadro de batalhas fiscais existentes no nível nacional.

No entanto, um estudo encomendado pela Assembleia Legislativa de Mato Grosso ao Tribunal de Contas do Estado (TCE) revelou que no período de 1998 a 2008, em Mato Grosso houve uma assimetria entre os incentivos fiscais e a contrapartida social, pois segundo o relatório o ritmo de geração de empregos é inferior ao ritmo da concessão de incentivos fiscais. "Ou seja, o crescimento observado na concessão de incentivos fiscais não tem 
resultado em crescimento proporcional de novos empregos." (MATO GROSSO, 2009, p. 94). Outro processo constatado no estudo revela uma concentração espacial dos incentivos, pois cidades como Cuiabá, Rondonópolis e Várzea Grande sediam as principais empresas beneficiadas. Isto se dá porque a maior parte dos incentivos fiscais está voltada para o fomento da industrialização e do comércio, principalmente de empresas inseridas no Programa de Desenvolvimento Industrial e Comercial de Mato Grosso (PRODEIC).

A Tabela 6, demonstra a evolução contínua deste programa a partir de 2007 e a sua consolidação como programa hegemônico de incentivos fiscais em Mato Grosso.

Tabela 6 - Renúncia fiscal no Estado de Mato Grosso de 2007 a 2013

\begin{tabular}{|c|c|c|c|c|c|c|c|c|c|c|c|c|c|c|}
\hline Programas e outros & 2007 & & 2008 & & 2009 & & 2010 & & 2011 & & 2012 & & 2013 & \\
\hline incentivos fiscais & $\mathrm{R} \$$ & $\%$ & $\mathrm{R} \$$ & $\%$ & $\mathrm{R} \$$ & $\%$ & $\mathrm{R} \$$ & $\%$ & $\mathrm{R} \$$ & $\%$ & $\mathrm{R} \$$ & $\%$ & $\mathrm{R} \$$ & $\%$ \\
\hline PROALMAT Agricultura & $106.047 .185,87$ & 17,1 & $99.545 .932,06$ & 9,19 & $70.468 .676,80$ & 6,19 & $117.405 .274,43$ & 11,6 & $103.637 .127,04$ & 9,94 & $17.030 .967,211$ & 1,51 & $1.299 .496,27$ & 0,1 \\
\hline PROARROZ Agricultura & 0,00 & 0 & 0,00 & 0 & 0,00 & 0 & 0,00 & 0 & 0,00 & 0 & 0,00 & 0 & 0,00 & \\
\hline PROALMAT Indústria & $1.671 .990,34$ & 0,27 & $1.284 .703,24$ & 0,12 & $962.013,57$ & 0,08 & 0,00 & 0 & $89.582,78$ & 0,01 & 0,00 & 0 & $247.703,34$ & \\
\hline PROARROZ Indústria & $11.170 .824,60$ & 1,8 & $8.082 .679,06$ & 0,75 & $3.922 .294,36$ & 0,34 & $1.715 .906,07$ & 0,17 & $868.194,17$ & 0,08 & $770.636,400$ & 0,07 & $682.722,30$ & $\mathrm{c}$ \\
\hline PRODEIC & $261.409 .406,47$ & 42,2 & $475.474 .481,32$ & 43,9 & $529.761 .010,46$ & 46,5 & $493.751 .249,80$ & 48,8 & $922.687 .726,53$ & 88,5 & 1.104.137.095,34 9 & 97,61 & $1.303 .082 .050,77$ & \\
\hline PROCAFE Indústria & $3.049 .044,75$ & 0,49 & $2.167 .093,76$ & 0,2 & $2.412 .970,13$ & 0,21 & $777.179,91$ & 0,08 & $247.972,72$ & 0,02 & 0,00 & 0 & 0,00 & \\
\hline PROLEITE & $16.794 .324,08$ & 2,71 & 11.148.227,09 & 1,03 & $11.767 .203,72$ & 1,03 & $13.191 .705,25$ & 1,3 & $5.217 .245,57$ & 0,5 & $61.407,080$ & 0,01 & $100.552,85$ & 0,01 \\
\hline PRODECIT & 0,00 & 0 & 0,00 & 0 & 0,00 & 0 & 0,00 & 0 & 0,00 & 0 & 0,00 & 0 & 0,00 & \\
\hline PRODETUR & 0,00 & 0 & 0,00 & 0 & 0,00 & 0 & 0,00 & 0 & 0,00 & 0 & 0,00 & 0 & 0,00 & \\
\hline PROMINERAÇÃO & 2.741.627,12 & 0,44 & $3.065 .403,08$ & 0,28 & $2.700 .172,66$ & 0,24 & $3.070 .575,97$ & 0,3 & $2.661 .510,24$ & 0,26 & $2.266 .042,74$ & 0,2 & $691.319,24$ & 05 \\
\hline PRODER & 0,00 & 0 & 0,00 & 0 & $864.399,12$ & 0,08 & $4.532 .841,15$ & 0,45 & $4.372 .942,30$ & 0,42 & $6.802 .989,91$ & 0,6 & 7.962.183,09 & ( \\
\hline PRODEI & $38.199 .831,38$ & 6,17 & $7.131 .290,83$ & 0,66 & 4.281.087,31 & 0,38 & $4.252 .356,42$ & 0,42 & $2.344 .180,89$ & 0,22 & 0,00 & 0 & 0,00 & \\
\hline Total Programas & $441.084 .234,61$ & 71,2 & $607.899 .810,44$ & 56,1 & $627.139 .828,13$ & 55,1 & $638.697 .089,00$ & 63,1 & 1.042.126.482,24 & 100 & $1.131 .069 .138,68^{\prime \prime}$ & 1001 & $1.314 .066 .027,86$ & 100 \\
\hline
\end{tabular}

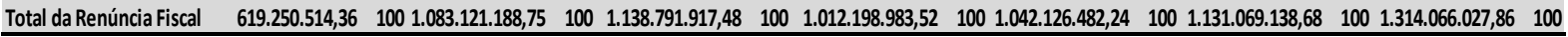
Fonte: Ma to Grosso. Balanço Geral do Estado de Mato Grosso (2008, 2009, 2010, 2011, 2012, 2013 e 2014) Org. LIMA, Ronei C. de (2014)

Observando o Gráfico 6, é possível verificar a evolução dos principais segmentos contemplados com a isenção fiscal dentro do PRODEIC. Por ser este o programa que concentra a ampla maioria dos recursos tributários renunciados - partindo de uma participação em 2007 de 42,2\%, para 99,2\% em 2013 - a sua análise representa um retrato fiel da relevância dos incentivos no cerne do crescimento de alguns setores produtivos. Em 2013, os cinco segmentos destacados no Gráfico 6, contabilizaram 82,6\% do total do PRODEIC. 


\section{Gráfico 6 - Evolução dos principais segmentos do PRODEIC de 2007 a 2013}

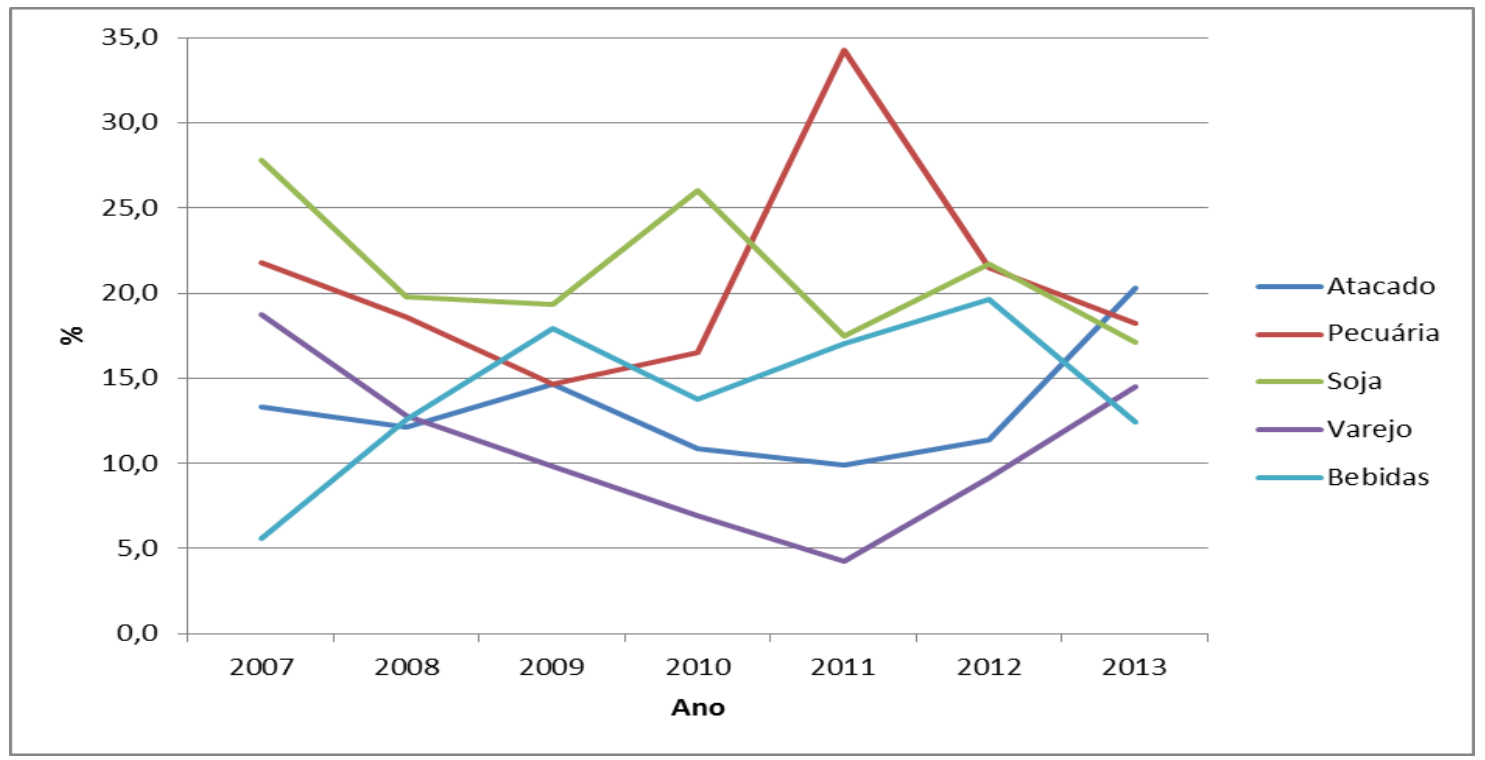

Fonte: Mato Grosso. Balanço Geral do Estado de Mato Grosso (2008, 2009, 2010, 2011,2012, 2013 e 2014)

Os segmentos de atacado e varejo estão relacionados aos incentivos voltados ao comércio, no contexto do crescimento urbano que demanda serviços e mercadorias para a manutenção das populações residentes nas principais cidades e na rede de trocas comerciais existentes no nível interurbano. Cidades como Cuiabá, Rondonópolis, Sinop, Cáceres e Barra do Garças movimentam um total de mercadorias muito além das suas próprias populações, daí a instalação de grandes redes atacadistas como Atacadão, Assaí e Macro que abastecem as unidades comerciais de menor porte e das cidades circunvizinhas.

Quanto aos segmentos da pecuária, da soja e de bebidas, estas compõem o segmento industrial, sendo as duas primeiras com caráter mais extrovertido, enquanto a segunda prioriza os mercados locais e o mercado regional (caso das indústrias de cervejas e de refrigerantes instaladas em Cuiabá (AMBEV), Várzea Grande (Renosa - Coca Cola) e Rondonópolis (Cervejaria Petrópolis)).

A ocorrência dos incentivos fiscais como atrativo de empresas não é um fato específico de Mato Grosso, nem do Brasil, mas uma prática generalizada globalmente, pois se trata de um processo maior no âmago da evolução do capitalismo que necessita se expandir geograficamente para buscar melhores condições de manutenção da sua reprodução.

Assim, Bordin (2003, p. 17), a partir de um esforço comparativo, face às dificuldades de padronização de informações e dos períodos diferenciados, apresenta um quadro 
comparativo internacional, colocando o Brasil na $12^{\mathrm{a}}$ posição (com 9,6\% de renúncia fiscal em 2003 em relação à arrecadação potencial) num total de 17 países, lista encabeçada por México (31,95\% em 2002), Irlanda (30,62\% em 1991), Canadá (29,92\% em 1995) e Estados Unidos (22,91\% em 1995).

Já Afonso et al (2014, p. 2) discute a questão interna com ênfase no Imposto sobre Operações relativas à Circulação de Mercadorias e sobre Prestações de Serviços de Transporte Interestadual e Intermunicipal e de Comunicação (ICMS), entendendo que a guerra fiscal que o envolve resulta, segundo o governo federal, na "[...] principal distorção a afetar a economia, especialmente pela incerteza jurídica que prejudica os investimentos produtivos no País.”.

Para os autores, apesar dos limites decorrentes de dados sem um padrão comum e pela ausência de informações de alguns estados, no conjunto de 20 unidades da federação para o ano de 2012, Mato Grosso ocupa a $11^{a}$ posição na escala nacional $(15,4 \%$ de renúncia fiscal em relação ao que foi arrecadado), mas no nível regional é o último, pois Goiás $\left(51,1 \%-2^{\mathrm{a}}\right.$ posição), Distrito Federal (22,4\% - $6^{\text {a }}$ posição) e Mato Grosso do Sul (19,7\% - $7^{a}$ posição) se mostraram mais agressivos na guerra fiscal (AFONSO et al, op. cit., p. 18).

O problema é que a escalada de renúncia fiscal limita a expansão dos investimentos que o Estado pode efetuar nas áreas sociais, bem como na infraestrutura de transportes, comunicações e energia que são atributos fundamentais na escolha dos empresários para a instalação de suas unidades. Portanto, entendemos que as isenções fiscais concedidas se somam ao conjunto de estratégias executadas pelo Estado (nos níveis federal, estadual e municipal) para favorecer o ambiente empresarial de diversas naturezas, e por conseguinte fomentar a corporatização do território.

\subsubsection{A infraestrutura de transportes como estratégia de atração}

A questão da concentração da atividade industrial em Mato Grosso tem um vínculo diretamente proporcional com as condições de infraestruturas (de transportes, energia e comunicações) dispostas no território. Ou seja, as áreas possuidoras de fixos facilitadores de fluxos diversos, notadamente de fluxos materiais (commodities) e fluxos imateriais 
(informacionais, financeiros, organizacionais) emergem como áreas preferenciais de investimentos corporativos.

Apesar de termos claro que existe uma interdependência entre as diversas infraestruturas no funcionamento corporativo do território, daremos ênfase às condições da infraestrutura de transportes, visto que esta promove a movimentação de mercadorias pelo território e é o elemento primordial das ações logísticas empresariais.

Segundo dados do IBGE (2014b), no cômputo total a indústria participou com 16,7\% do PIB de Mato Grosso em 2011 e 14,1\% em 2012, sendo que os dez municípios com maior participação neste setor em 2012 acumulam 63,8\% do total, o que nos autoriza a falar em concentração do setor industrial em Mato Grosso.

A concentração espacial das plantas industriais possui singularidades importantes. Assim, optamos por apresentá-las por eixos, porque entendemos que existe estreita relação entre os sistemas de transportes implantados (tratados como eixos de escoamento pela política nacional) e a existência de fixos industriais.

Temos claro, no entanto, que não são eixos isolados, mas do contrário, são articulados entre si de formas diversas, seja pela coincidência em diversos trechos (BRs 163, 364 e 070), como pela função demandada, qual seja o escoamento da produção para o mercado externo e suprimento da demanda doméstica. Os eixos destacados servem de sistemas-tronco para as rodovias estaduais e estradas vicinais.

Consideraremos os seguintes eixos: a) Eixo da Área Concentrada da Indústria (Rondonópolis, Cuiabá e Várzea Grande); Eixo da BR-163 Médio-Norte (Lucas do Rio Verde, Nova Mutum, Sorriso e Sinop); Eixo Sul da BR-364/ALLMN (Alto Araguaia); Eixo Oeste da BR-364 (Tangará da Serra) e Eixo Leste da BR-070 (Primavera do Leste). Os Gráficos 7, 8 e 9, apresentam a evolução do PIB industrial nos eixos citados, sendo que no Gráfico 9, optamos pelo agrupamento dos três últimos eixos por uma questão de melhor apresentação visual e efeito comparativo. 
Gráfico 7 - Evolução do PIB industrial do Eixo da Área Concentrada da Indústria de 1999 a 2012

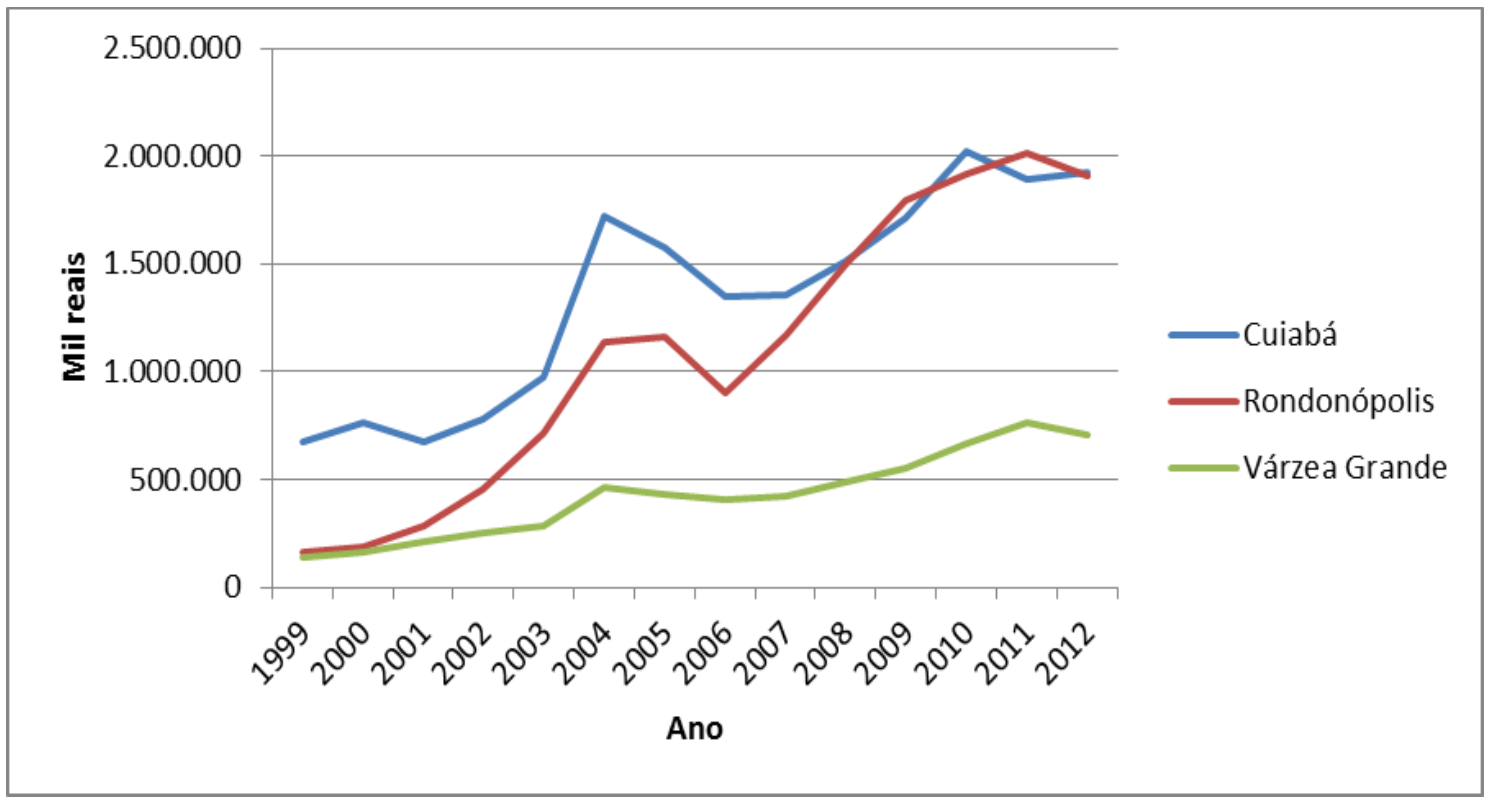

Fonte: IBGE, 2014b - Produto interno bruto dos municípios de 1999 a 2012

Em conjunto, o eixo da Área Concentrada da Indústria respondeu em 2012, por $40 \%$ do total da produção industrial, possuindo uma estrutura industrial mais diversificada, pois conta com empresas de diversos segmentos: processamento de grãos, frigoríficos, química (tintas, filmes plásticos), metal (chapas, colunas), fertilizantes (misturadoras), couros, rações, construção civil, têxtil e de alimentos.

Apesar da diversidade, este eixo apresenta uma queda na participação total, pois em 1999 representava 51\% da produção industrial, enquanto que em 2012 totalizava 40\%. Este quadro decorre de uma maior evolução da indústria localizada no interior, principalmente daquela que se territorializa no eixo da BR-163 Médio-Norte. Dos municípios do eixo da Área Concentrada, Rondonópolis apresenta o maior crescimento, pois participava com 9\% em 1999 e em 2012 já alcança 17\% do total do estado.

O reflexo do crescimento do setor industrial em Rondonópolis pode ser analisado pela sua espacialização em diversas áreas do município. Na Figura 10, é possível observar que não houve uma concentração espacial, mas pelo contrário, as empresas se estabeleceram em áreas espalhadas por todo o perímetro urbano (áreas destacadas em laranja na figura), estando 
sempre próximas de importantes vias de acesso rodoviário e, no caso daquelas instaladas no Complexo Intermodal de Rondonópolis (CIR), também da via ferroviária.

\section{Figura 10 - Localização de áreas industriais em Rondonópolis em 2014}

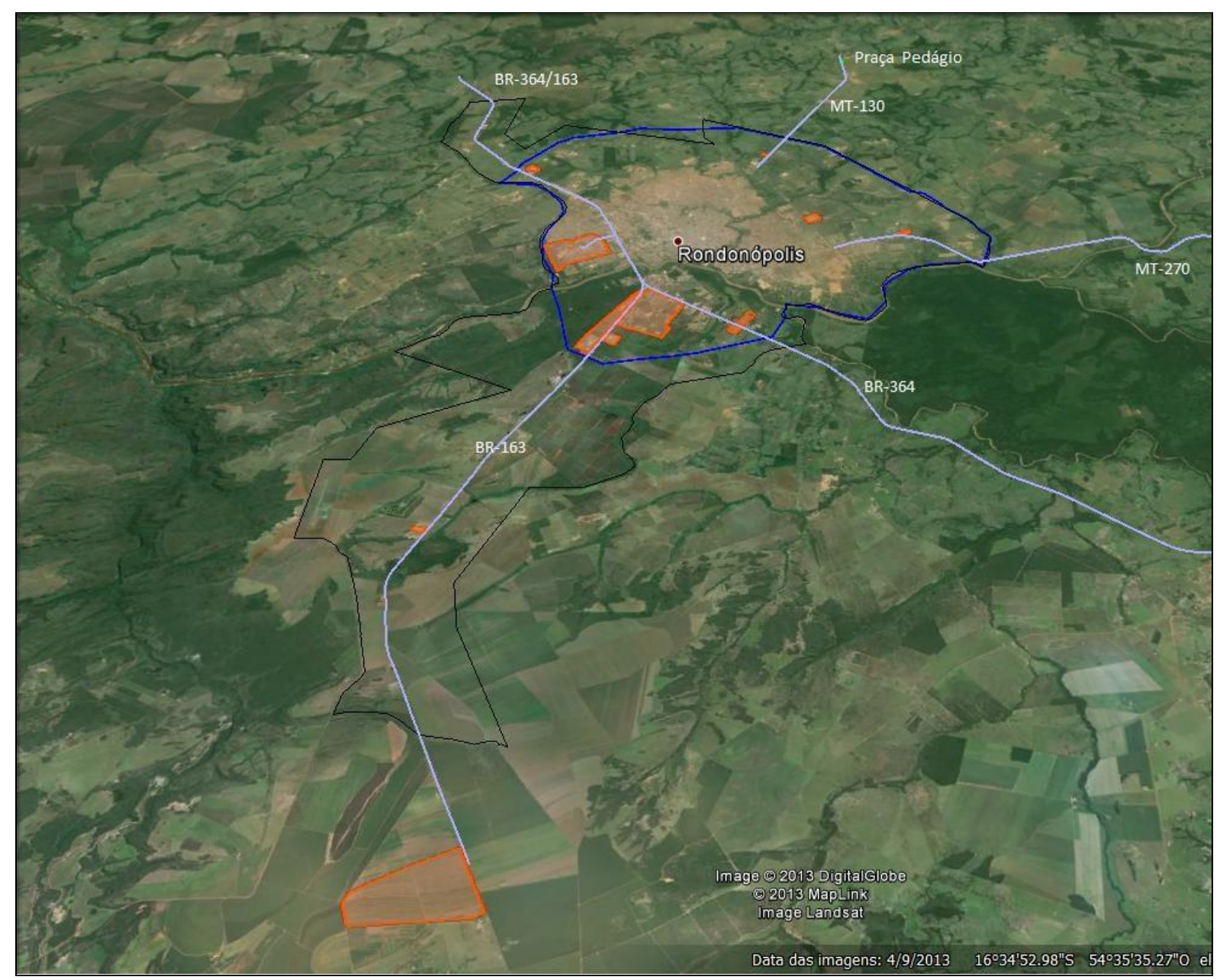

Fonte: LIMA, Ronei C. de (2014) - Trabalho de campo em janeiro de 2014 sobre base do Google Earth

Entretanto, alguns fatos demostram certa instabilidade do setor no município, pois grandes empresas do agronegócio, que iniciaram suas atividades na produção de agrotóxicos, como no caso da Nortox, e do ramo têxtil, representado pela Santana Textiles, encerraram suas atividades de produção industrial no município. Enquanto a Nortox continuou utilizando as suas instalações como entreposto comercial, a Santana Textiles encerrou suas atividades após problemas financeiros do grupo proprietário. Esses fatos podem representar apenas condições conjunturais, com a empresa de agrotóxicos com problemas de funcionamento em face de questões ambientais, e a empresa têxtil com problemas relacionados à sanidade financeira, com dificuldades de pagamento de fornecedores. No entanto, as vagas de emprego alardeadas pelos governantes - quando da instalação das plantas industriais e da concessão de 
isenções fiscais e terrenos - são perdidas e a sensação de uma diversificação do setor industrial ligado ao agronegócio diminui o seu ímpeto.

Todavia, considerando um horizonte mais amplo e estrutural, entendemos que a instalação do terminal ferroviário da ALLMN, além de uma expansão do perímetro urbano para que o mesmo alcançasse as instalações do terminal, permitiu a criação de uma nova área industrial nos 400 hectares do condomínio industrial gerido pela ALL, demonstrando a possibilidade de nova onda de expansão industrial em Rondonópolis.

Atualmente, além do terminal da própria ALL e do terminal da Brado Logística, que pertencem ao mesmo grupo, temos as instalações de processamento de grãos da Noble e de distribuição de combustíveis da Raízen (joint venture entre Cosan e Shell), que a partir da fusão da Rumo (Cosan) com a ALL, passou a pertencer ao mesmo grupo, agora denominado Rumo ALL.

A Figura 11, permite uma visualização das atuais instalações em funcionamento e também das instalações em construção no terminal ferroviário da ALL em Rondonópolis. 
Figura 11 - Instalações no terminal da ALLMN em Rondonópolis em junho de 2015

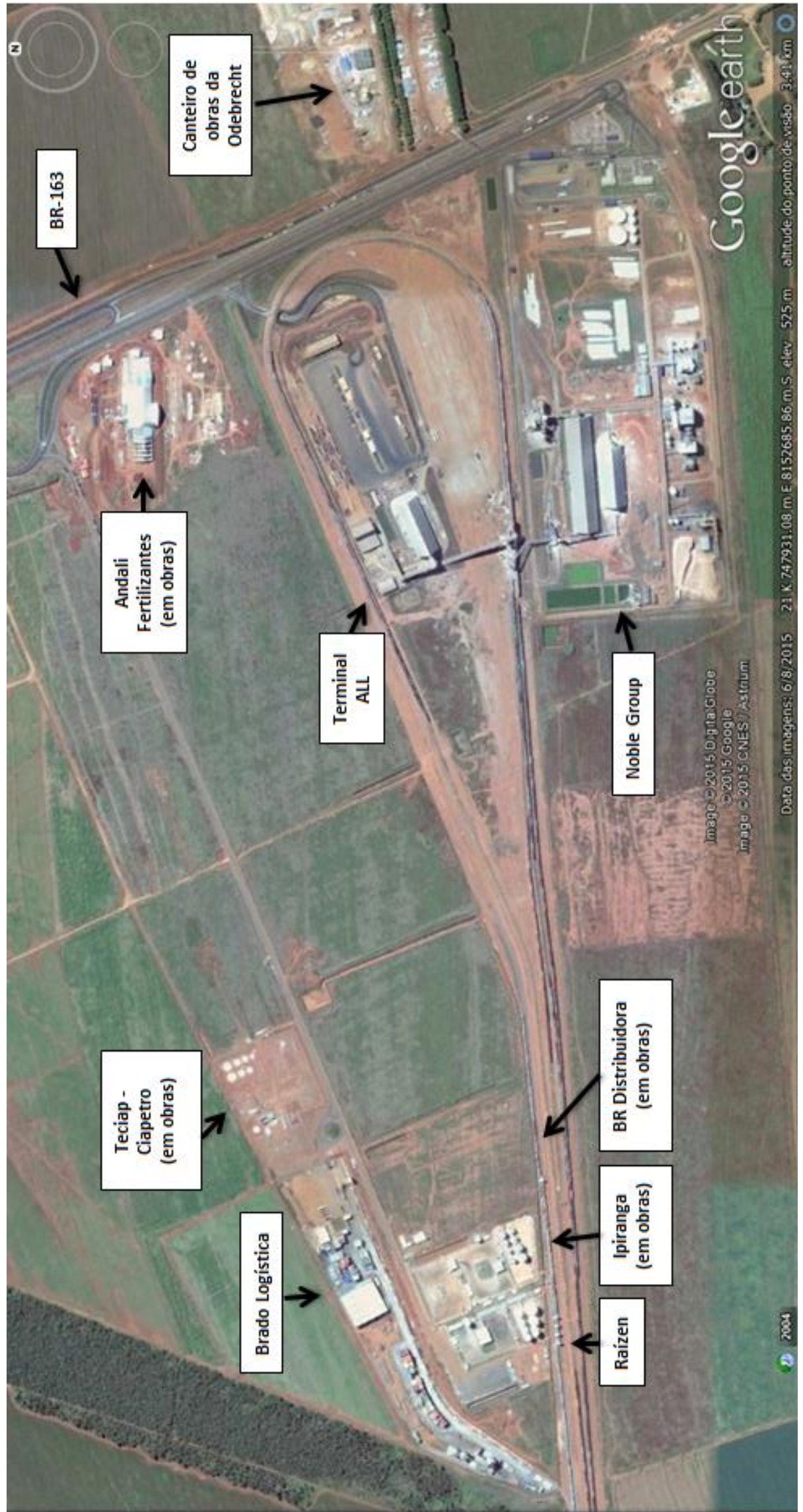

Fonte: LIMA, Ronei C. de (2015) - Trabalho de campo em 2014 e 2015 sobre base do Google Earth 
Como a ALLMN possui concessão somente até o terminal de Rondonópolis, estima-se que os investimentos do grupo passem a girar principalmente neste terminal, pois o mesmo além da localizar-se nas imediações das principais rodovias do estado (BR-163 e BR-364), atende, pela intermodalidade de transportes, vasta área do estado. Como destaques temos a movimentação de cargas como fertilizantes e derivados de petróleo para Mato Grosso e de grãos e derivados para exportação (porto de Santos) e biodiesel e etanol para Paulínia-SP (caso das operações da Raízen que tiveram início em junho de 2015).

De acordo com Márcio Augusto Martines, gerente do terminal da Rumo ALL, os investimentos previstos para o terminal estão voltados ao aumento da sua capacidade estática para melhorar a operacionalidade de carga e descarga, para a construção do pátio de triagem para cerca de 1.600 caminhões e do posto de combustíveis e a finalização das instalações da empresa Andali, empresa do setor de fertilizantes que é subsidiária do grupo estadunidense CHS.

Foi possível apurar nas pesquisas de campo que grandes empresas do agronegócio, como Amaggi, Bunge, CGG e ADM adquiriram terrenos no Complexo Intermodal de Rondonópolis, visto que o terminal é estratégico por fazer a ligação com o principal eixo de escoamento de grãos e derivados, biodiesel e etanol e também porque a logística de transportes e armazenagem dessas empresas está consolidada no complexo portuário de Santos. Nesse complexo temos os seguintes terminais de grãos das tradings citadas: o Terminal de Granéis do Guarujá S.A (TGG) empresa pertencente aos grupos ALL, Bunge e Amaggi, o Terminal da ADM do Brasil Ltda., e o terminal T-GRÃO, pertencente ao grupo CGG (PORTO DE SANTOS, 2015).

No entanto, toda essa dinâmica de crescimento de fluxos de commodities voltadas ao porto de Santos, bem como para os portos de Vitória, Paranaguá e São Francisco do Sul, poderá apresentar limites na expansão das operações com grãos e com os demais itens da cadeia produtiva, caso a consolidação da inversão logística para o Norte (portos de Miritituba, Santarém, Vila do Conde, localizados no Pará, Santana, no Amapá e Itaqui e Ponta da Madeira no Maranhão) se mantenha em ritmo crescente. Fomentam esse quadro de inversão logística as melhorias de trafegabilidade da BR-163, e ainda, a futura concessão da Ferrovia de Integração do Centro-Oeste (FICO), bem como a possibilidade de criação da ferrovia entre Lucas do Rio Verde ou Sinop e a estação de transbordo de cargas (ETC) em Miritituba/Itaituba-PA, iniciativa defendida pelo setor produtivo. 
Contudo, quem termina definindo os rumos dos fluxos são as tradings, cujas operações se territorializam em todo o estado de Mato Grosso - por meio de processadoras, armazéns, terminais de transbordo -, e por isso controlam a destinação da produção. E, como essas empresas estão localizadas estrategicamente nos principais portos do país, nos quais investem recursos em capital fixo e modernização dos processos de movimentação de cargas, devem continuar buscando as vantagens oferecidas pelo mercado, inclusive as melhorias efetivadas pelos administradores dos portos que iniciam uma disputa por cargas.

Dessa forma, o ritmo de crescimento do eixo da Área Concentrada da Indústria (Cuiabá-Rondonópolis-Várzea Grande) depende das estratégias dos agentes hegemônicos, cujo controle das ações sobre o território pode determinar a sua consolidação como dínamo da economia mato-grossense, ou reestruturar o território com vistas à ascensão de outros eixos que se tornam possuidores de vantagens comparativas e com isso passam a apresentar perspectivas favoráveis ao setor corporativo do agronegócio.

Nesse contexto, ao analisarmos outras dinâmicas territoriais cujo dinamismo industrial está diretamente relacionado com a crescente produção, verificamos que o eixo da BR-163 Médio-Norte, conforme demonstra o Gráfico 8, apresenta um crescimento acentuado dos quatro municípios (Lucas do Rio Verde, Nova Mutum, Sinop e Sorriso), mas com maior destaque para Lucas do Rio Verde que assume a liderança da produção industrial em 2008 (ano de instalação da BRF (Sadia) no município) e mantém essa condição em 2012.

O perfil da produção industrial desse eixo está diretamente relacionado à cadeia do agronegócio, principalmente da cadeia carne e grãos, com destaque para as processadoras de grãos: (Bunge em Nova Mutum e Sorriso, Amaggi em Lucas do Rio Verde e Caramuru em Sorriso); os frigoríficos: da BRF (aves) em Lucas do Rio Verde e Nova Mutum, Frigobom e Frialto (bovinos) em Sinop, Delicious Fish (peixes) e Anhambi (aves) em Sorriso; e a empresa Dânica (câmaras frigoríficas industriais) em Lucas do Rio Verde. 
Gráfico 8 - Evolução do PIB industrial do Eixo da BR-163 Médio-Norte de 1999 a 2012

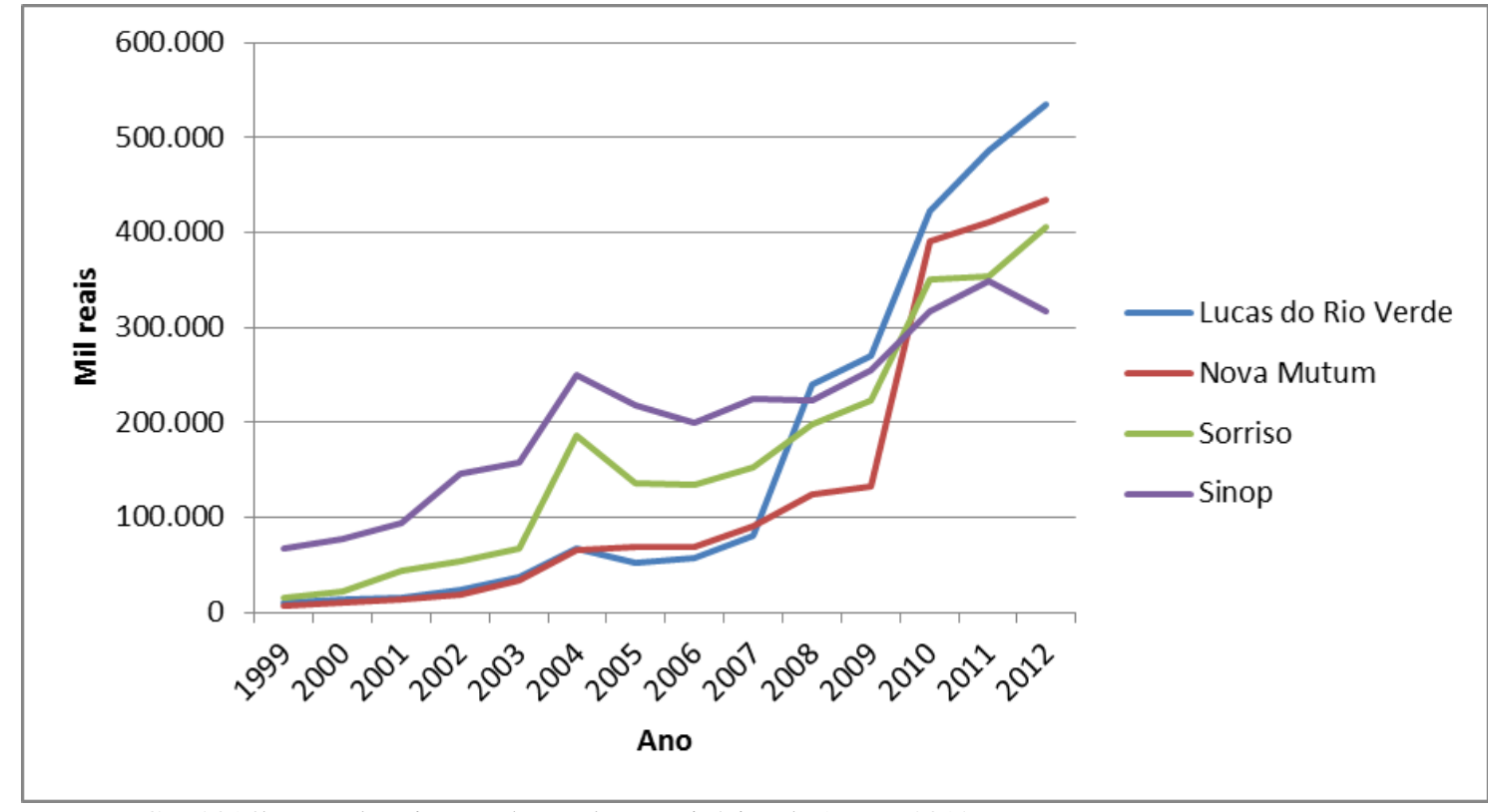

Fonte: IBGE, 2014b - Produto interno bruto dos municípios de 1999 a 2012

Esse é um dos eixos que atualmente sofrem com o escoamento da produção, apesar da BR-163 ser o principal tronco rodoviário de Mato Grosso. No entanto, o problema das condições da logística de transportes dessa região, derivado da distância em relação aos principais mercados, pode ser minimizado com a existência de outras logísticas, como coloca Bernardes (2010, p. 18) ao apontar as logísticas referentes ao "conjunto de competências infraestruturais" composto de fixos como armazéns, mas também elementos normativos como instituições, normas, agências reguladoras e o "conhecimento técnico dos prestadores de serviços". De acordo com a autora, no seu conjunto esses aspectos permitem uma maior competitividade às atividades da região, nos moldes do que já se emprega na produção agrícola pelos agentes hegemônicos e na criação de áreas de especialização produtiva.

Condição parecida pode ser observada em Primavera do Leste - destaque do eixo da BR-070 Leste -, conforme aponta o Gráfico 9, que possui uma produção industrial com base no processamento de grãos e algodão, produzidos em larga escala neste município e no vizinho município de Campo Verde. A arrancada do setor industrial se dá com a instalação da fábrica da Cargill, em 2009, demonstrando, ainda, uma dependência de setores específicos, caso do processamento de grãos, em detrimento de uma maior diversidade de segmentos envolvidos. 
Gráfico 9 - Evolução do PIB industrial dos Eixos da BR-070 Leste, da BR-364 Oeste e BR-364/ALLMN de 1999 a 2012

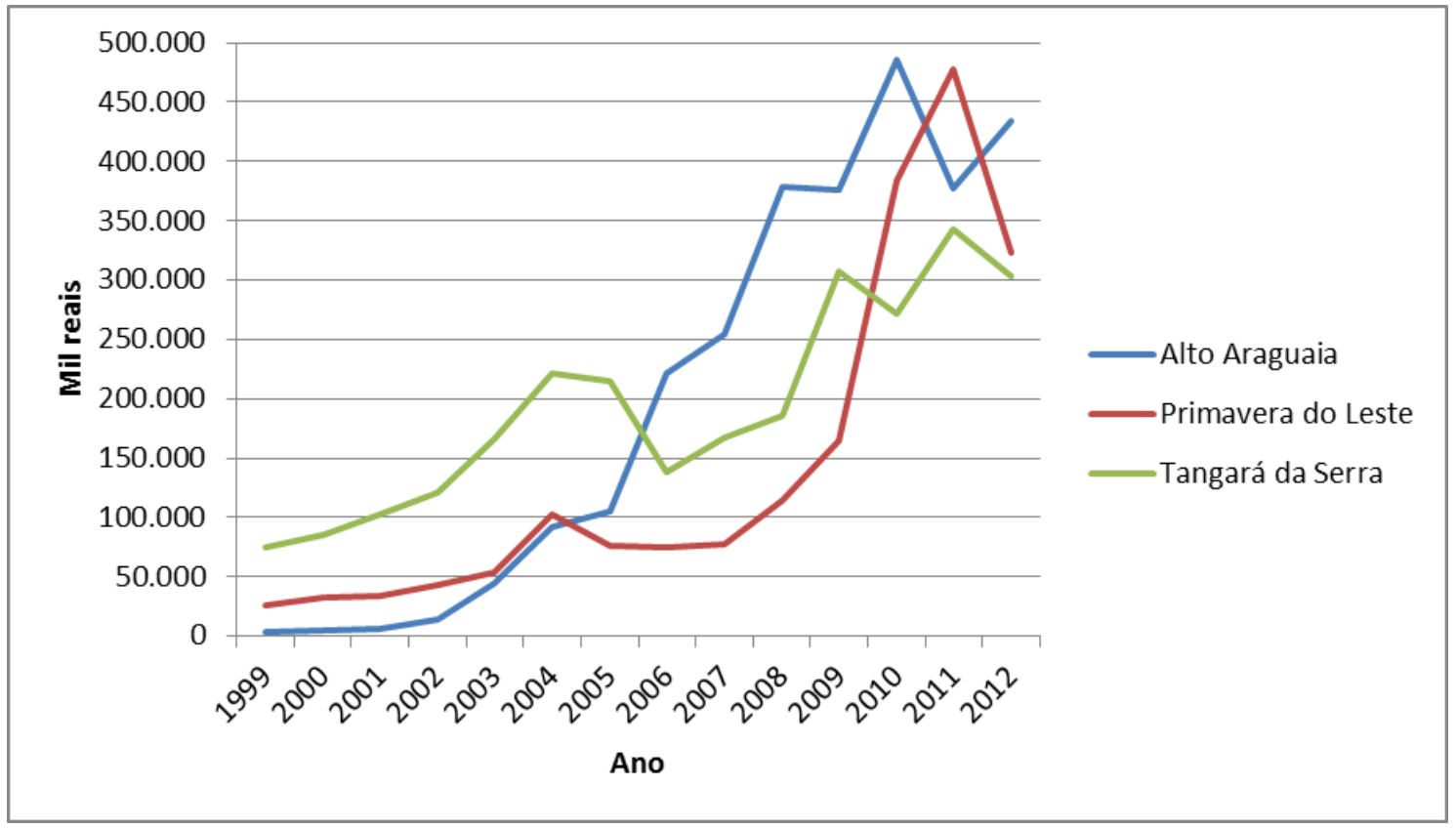

Fonte: IBGE, 2014b - Produto interno bruto dos municípios de 1999 a 2012

No Gráfico 9, temos também a evolução da produção industrial do município de Tangará da Serra que apresenta a melhor marca no ano de 2011, com leve queda no ano seguinte. Apesar de ser uma cidade polo do Oeste mato-grossense, também baseia sua produção industrial em empresas de alimentos, caso dos frigoríficos Marfrig (bovinos) e Anhambi Norte (aves). No conjunto do grupo, perde em produção industrial para Alto Araguaia e Primavera do Leste.

No entanto, o município tenta aumentar a participação do setor industrial na economia local por meio de incentivos municipais que se somam aos programas governamentais como o PRODEI e PRODEIC. A concessão de benefícios (fiscais e de infraestrutura) está normatizada pela Lei $\mathrm{n}^{\mathrm{o}} 3.445$ de 27 de outubro de 2010, que estabelece critérios para questões como doações de áreas, disponibilidade de equipamentos urbanos (água, luz, saneamento básico) e da isenção fiscal de impostos e taxas (TANGARÁ DA SERRA, 2010).

No cômputo geral, a maior parte dos estabelecimentos de Tangará da Serra é de pequeno porte e atende a reprodução da vida urbana local e da região de entorno. A diversificação existente representa, dessa forma, uma maior segurança para a economia local. De outro lado, as maiores empresas estão diretamente relacionadas com as oscilações do 
mercado - no caso da Marfrig ao mercado internacional - o que impossibilita, nesse caso, um maior controle do local nas condições de crescimento e estabilidade dessas empresas.

Isto ocorre porque as forças motoras que sustentam a evolução econômica não respondem ao mando local, como é regra na maior parte do território mato-grossense, pois tendem a manter a solidariedade organizacional, e assim, as regiões "[...] existem porque sobre elas se impõem arranjos organizacionais, criadores de uma coesão organizacional baseada em racionalidades de origens distantes [...]" que passam a se estabelecer como condições essenciais das regiões. (SANTOS, 2008a, p. 285).

Por fim, o município de Alto Araguaia, cuja dinâmica da evolução econômica já fora inicialmente analisada, representa um exemplo concreto das forças de atração que o adensamento do sistema de engenharia de transportes (rodoviário e ferroviário) pode provocar a um lugar, pois parte de uma representatividade mínima em 1999 a um pico de crescimento em 2010 e oscilações entre 2011 (viés de baixa) e 2012 (viés de alta). Com a instalação de empresas como a Louis Dreyfus Commodities (LDC) com operações de processamento de grãos e algodão, da Galvani (fertilizantes), e da Agrenco (Biodiesel e processamento de soja) inicia-se um novo ciclo com base na agregação de valor à produção de grãos.

Mas, em virtude de problemas decorrentes da crise financeira internacional e de gestão interna a Agrenco não chegou a produzir na unidade de Alto Araguaia e atualmente a unidade neste município encontra-se fechada.

De uma economia baseada na agropecuária, o salto para a industrialização concentrada no setor de grãos e fertilizantes parecia favorecer a um crescimento da economia ancorado nas novas empresas que fomentariam os demais setores. Porém, o modelo adotado, baseado em grandes empresas cujas estratégias se conectam aos circuitos dos mercados globais, se mostra instável em alguns casos, prejudicando diretamente as ações do ente público, caso da prefeitura local que previa aumento substancial da arrecadação, mas observa uma redução sistemática dos valores arrecadados.

Em suma, os eixos aqui apresentados convergem para as seguintes características:

a) Relação direta das instalações industriais com a produção (principalmente de grãos e de bovinos, suínos e aves); 
b) Influência determinante da existência de sistemas de transportes para a localização das unidades industriais (os municípios selecionados são servidos pelas rodovias federais que atravessam o estado de Mato Grosso; a existência de sistemas de transportes - no caso a ferrovia, foi determinante para a evolução industrial de Alto Araguaia);

c) Articulações extrovertidas, notadamente das tradings (processadoras de grãos e dos frigoríficos exportadores);

d) Integração das atividades em cadeia (caso da cadeia carne e grãos, cujo principal destaque se encontra no eixo da BR-163 Médio Norte, mas também presente em Rondonópolis, Primavera do Leste e Tangará da Serra);

e) Pouca diversificação da produção (excetuando-se em parte os municípios do eixo da Área Concentrada);

f) Produção de baixa intensidade tecnológica e de baixo valor agregado (por vincular-se à produção de commodities);

g) Produção de grandes volumes que demandam uma logística de transporte baseada na intermodalidade, elemento novo e concentrado na porção Sul do estado de Mato Grosso.

Essas características possuem relações de interdependência, o que pressupõe a inexistência de ações isoladas. Para melhor compreender o seu funcionamento, esboçamos a matriz do sistema em seu funcionamento mais geral, conforme pode ser observado na Figura 12. 
Figura 12 - Sistema de funcionamento da agroindústria nos eixos

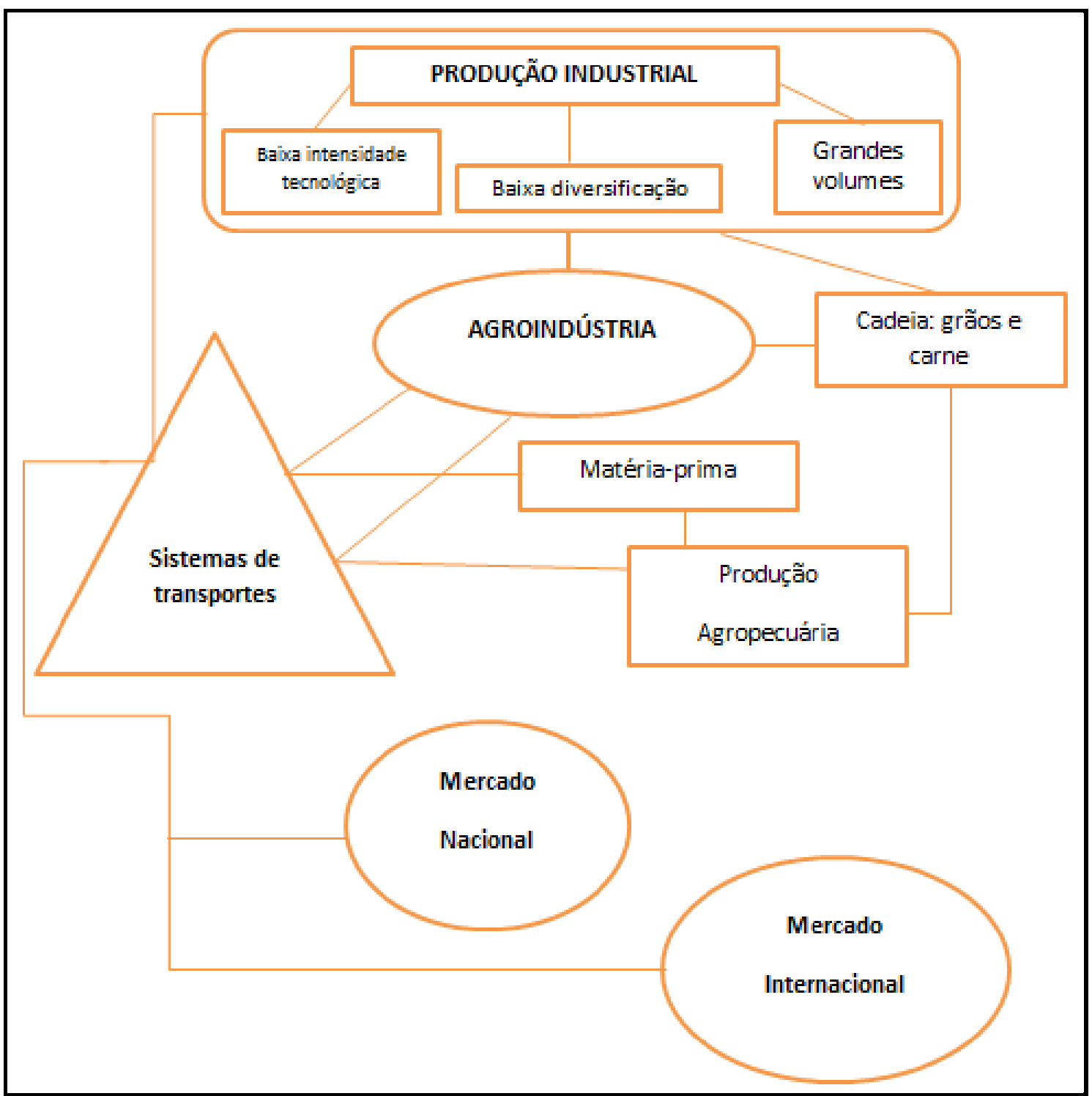

Fonte: Trabalho de campo

Organização: LIMA, R. C. (2015)

A concentração espacial da produção industrial pode ser visualizada no Mapa 9, que apresenta uma classificação dos municípios de Rondonópolis, Alto Araguaia, Primavera do Leste, Cuiabá, Várzea Grande, Tangará da Serra, Nova Mutum, Lucas do Rio Verde, Sorriso e Sinop, em relação ao PIB industrial de 2012 (IBGE, 2014b) e com a produção de soja estimada de 2014 (IMEA, 2014) para todo o estado de Mato Grosso. 
Mapa 9 - Concentração espacial da produção industrial de 2012 em municípios selecionados de Mato Grosso e a produção de soja no estado em 2014

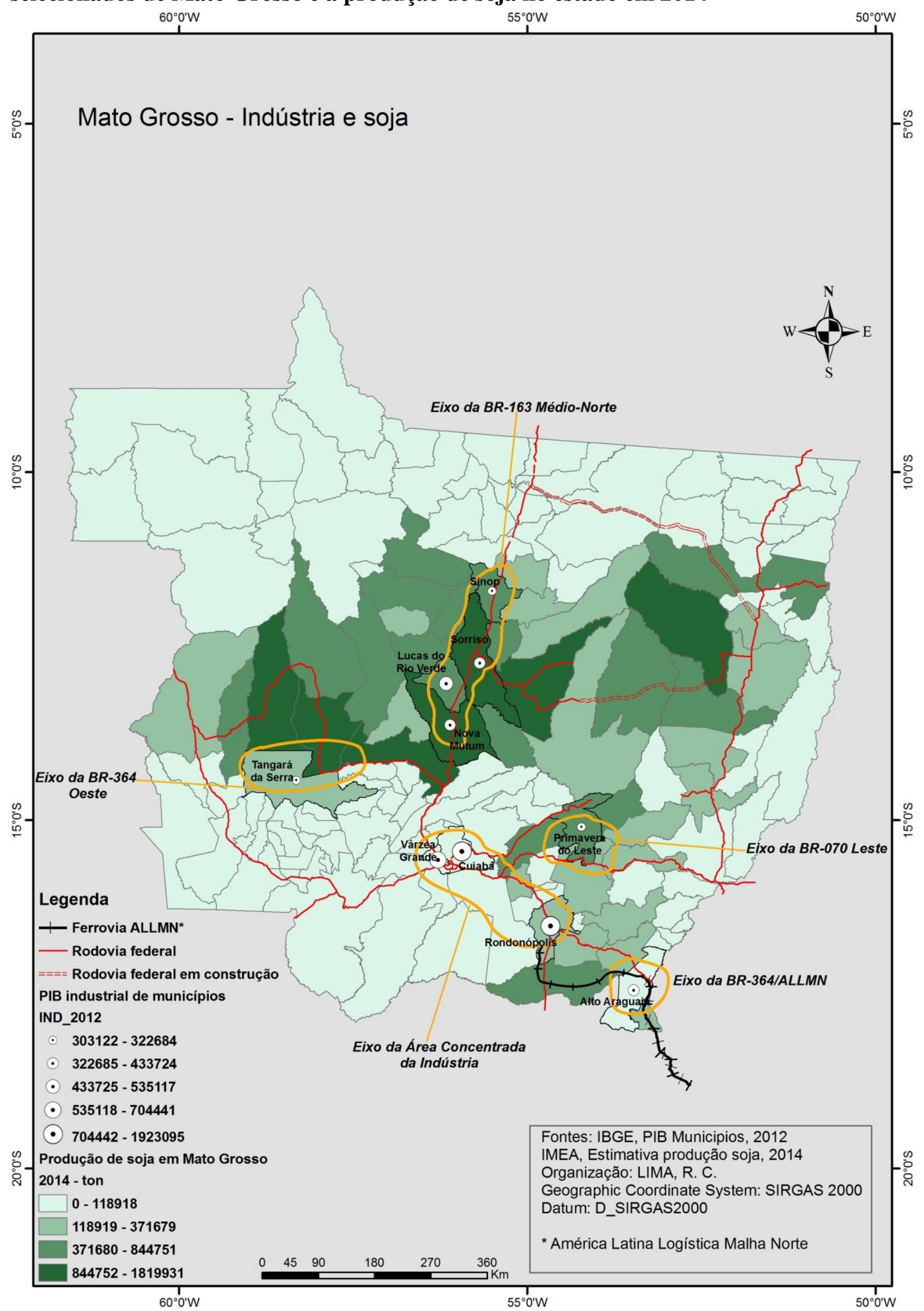

Fontes: IBGE (2014b), PIB dos municípios em 2012 e IMEA (2014), Estimativa da produção de soja de 2014. 
A definição dos eixos serve apenas para demonstrar parcialmente a dinâmica produtiva mato-grossense em seu movimento, cuja complexidade não pode ser alcançada em sua totalidade, visto que se encontra em totalização permanente e funciona por meio de mecanismos diversos, tangíveis e intangíveis.

Mas, nos parece possível fazer a relação entre os elementos destacados, quais sejam, existência de infraestruturas de transportes - assim como de energia e comunicação -, que criam forças centrípetas que atraem investimentos produtivos. Da mesma forma, concorrem as normatizações - em forma de incentivos fiscais e facilitação de ordens diversas (doações de terrenos e equipamento dos mesmos com infraestrutura básica) e a associação do Estado (FCO, SUDAM, BNDES) nos diversos níveis - para a consecução de fixos corporativos.

Contudo é a produção agropecuária que possibilita - em associação com os demais elementos, mas com certa ascendência -, a consecução da dinâmica que demanda a fluidez corporativa. No entanto, a diacronia entre aumento da produção e os sistemas de transportes instalados cria um quadro permeado por gargalos logísticos diversos.

Esses gargalos, que estão no foco das discussões dos setores hegemônicos, resultam da falta de planejamento das ações efetuadas sobre o território, implicando atualmente em pressões sobre os sistemas de engenharias existentes cuja manutenção e ampliação foram prejudicadas por forças internas e externas, advindas, entre outros motivos, da intensificação da integração nacional ao mercado internacional.

A seguir discutiremos a questão dos gargalos logísticos que prejudicam a fluidez corporativa em Mato Grosso.

\subsection{A LOGÍSTICA DE TRANSPORTES INCOMPLETA: OS GARGALOS LOGÍSTICOS}

A sustentação da expansão do agronegócio de Mato Grosso depende da competitividade do setor frente às demandas do mercado internacional de commodities, pois o setor possui uma característica de extroversão que determina os seus horizontes produtivos. 
Assim, para aumentar a competitividade, lança-se mão de estratégias diversas, como o emprego de sementes melhoradas, fertilizantes, maquinário, mão de obra especializada, que promove uma ampliação da produtividade. Porém, como a redução dos custos é uma necessidade constante em tempos de flexibilização da economia capitalista, o setor produtivo busca otimizar os fatores positivos alcançados e combater os fatores negativos que impedem uma realização plena da reprodução ampliada do capital.

Um setor crítico, principalmente para o agronegócio mato-grossense, é o setor de transportes, pois este apresenta em seu conjunto uma série de deficiências que impedem uma redução sistemática dos custos operacionais com vistas a uma maior competitividade e, como esclarece Carlos (1994, p. 110):

A busca por baixos preços de transporte é uma condição da produção baseada no capital, já que o produto só pode ser valorizado maciçamente em mercados longínquos se os custos de transporte forem baixos. Os meios de comunicação e transporte tornam-se simples esferas da valorização de um trabalho explorado pelo capital.

Como a valorização da produção está diretamente relacionada ao lócus da produção, visto existir uma pressão de alta nos custos de transportes condicionada à razão das maiores distâncias e da menor eficiência dos sistemas de transportes, surge a necessidade de investimentos para reduzir os impactos decorrentes da condição de distanciamento espacial, que pode levar à desvalorização da produção frente a outras áreas produtoras. Mas é importante lembrar que a condição de custos está vinculada ao tipo de modal de transporte, por isso ao investir pontualmente em sistemas menos onerosos para a circulação das commodities, como as hidrovias e ferrovias - associadas a sistemas informacionais -, mesmo áreas mais distantes, porém dotadas desses recursos técnicos, passam a comportar uma condição vantajosa se comparada às áreas dotadas, por exemplo, de rodovias em condições precárias, mesmo mais próximas das áreas consumidoras.

Toledo (2007, p. 8) ao abordar os investimentos efetuados pelas grandes empresas, com a colaboração do Estado, nos sistemas de engenharias com vistas à fluidez da produção, argumenta que "[...] a lógica da competitividade extrapola a produção agrícola e se projeta na modernização e expansão de redes de fluxos" sendo estes os fluxos materiais, que estão vinculados ao processo produtivo em si, e os fluxos imateriais, formado pelo capital, 
informações e ordens. Para o autor, este processo se dá no bojo de uma demanda por fluidez inerente ao aprofundamento imposto por uma divisão territorial do trabalho.

Entendemos que a incompletude do processo de reestruturação do território, capitaneado pelo Estado, resultou no surgimento de gargalos logísticos do setor de transportes que impactam diretamente o setor produtivo, impedindo uma maior fluidez da produção em Mato Grosso. Assim, por maior que tenha sido o esforço do Estado para promover a corporatização do território, não se estabeleceu, em longo prazo, as condições ideais para atender as demandas do agronegócio.

A concentração dos investimentos em um só modal (o rodoviário) criou uma irracionalidade logística na medida em que criou uma dependência a um único sistema de transportes, impossibilitando a intermodalidade que resultaria em uma maior otimização dos sistemas de engenharia de transportes, contrariando as experiências bem sucedidas em outros países.

De acordo com um estudo feito pela Associação Nacional dos Usuários do Transporte de Carga (ANUT) em 2008, o acirramento da concorrência internacional no mercado de commodities fez com que os sistemas logísticos eficientes se tornassem ainda mais fundamentais, pois os maiores concorrentes do agronegócio brasileiro, os Estados Unidos e a Argentina, apresentam vantagens em seus sistemas de transportes de cargas, o que não ocorre no Brasil. Enquanto para os argentinos as menores distâncias permite o uso do modal rodoviário, os produtores dos EUA compensam as longas distâncias com o uso eficiente de rodovias e hidrovias (ANUT, 2008, p. 72).

Revela ainda que a logística, considerada enquanto o conjunto formado por transporte, armazenagem e portos, é um dos pontos fracos do agronegócio brasileiro, devendo ser repensada e reestruturada de acordo com os interesses corporativos.

Como já informamos anteriormente, as condições de armazenagem não atendem a demanda da produção e, da mesma forma, as condições das vias por onde são movimentadas as cargas não estão adequadas à nova intensidade dos fluxos gerados. Quanto aos portos, as dificuldades operacionais implicam em custos mais elevados e no atraso de carregamentos e descarregamentos, colaborando com a redução da fluidez das cargas transportadas. No conjunto, estes itens promovem gargalos que obstaculizam a competitividade exigida pela integração dos mercados. 
Alguns impedimentos para a fluidez corporativa, no que tange a movimentação de commodities e as trocas comerciais favoráveis pelos menores custos, estão a seguir elencados e foram distribuídos por modais de transportes.

\subsubsection{Modal rodoviário}

\section{Pavimentação incompleta da BR-163 no Pará}

O trecho paraense da BR-163, que não é totalmente pavimentada, prejudica o escoamento via modal rodoviário da produção do Médio-Norte de Mato Grosso rumo aos portos paraenses de Miritituba e Santarém.

Com potencial para gerar repercussões em áreas da Amazônia brasileira, por mais de 30 anos esse eixo não recebeu os investimentos necessários para o seu funcionamento pleno. De acordo com Fortuna (2006, p. 259) “A estruturação desse eixo em questão é na forma de uma fronteira - corredor de exportação da Amazônia em direção ao Oceano Atlântico”.

Apesar de pressões nacionais e internacionais, a pavimentação deste trecho da rodovia está em andamento, mas o trecho do $\mathrm{km} \mathrm{493,63} \mathrm{ao} \mathrm{km} \mathrm{619,} \mathrm{que} \mathrm{dá} \mathrm{acesso} \mathrm{ao} \mathrm{Distrito} \mathrm{de}$ Miritituba e ao seu porto encontra-se ainda com revestimento primário (BRASIL, 2014g) ocasionando interrupções dos fluxos de cargas oriundas de Mato Grosso, no período das chuvas, exigindo a execução de obras emergenciais para liberar o tráfego como ocorreu em fevereiro de 2014 quando cerca de dois mil caminhões ficaram parados por conta de atoleiros (PRESSINOTT, 2014).

Apesar dos problemas, o porto de Santarém se situa entre os principais portos responsáveis pelo escoamento de grãos oriundos de Mato Grosso. Segundo dados do IMEA (2015b) e IMEA (2015c) em 2014, foram escoadas cerca de 615.190 toneladas de soja e 832.018 toneladas de milho, totalizando 1.447.208 toneladas, o que tornou este porto o quinto mais importante para o agronegócio mato-grossense. No entanto, em virtude das dificuldades de escoamento da produção por esta rota - a mais racional do ponto de vista dos custos logísticos -, temos um aprofundamento dos problemas nos trechos mato-grossense da BR-163 
e da BR-364 que continuam sendo responsáveis pela maior parte do movimento de commodities.

\section{BR-163 e BR-364 em Mato Grosso}

Por se tratarem dos principais troncos rodoviários que atravessam o estado de Mato Grosso, há uma necessidade premente de readequação das rodovias federais BR-163 e BR364 frente à intensificação da movimentação de cargas e de veículos de passeio. Como o trecho da BR-163 foi leiloado e receberá investimentos, por parte da empresa concessionária e do governo federal, haverá uma melhoria nas condições de tráfego, porém com o repasse dos custos inerentes à privatização do trecho na forma de cobrança de pedágio.

Mas até que as obras sejam totalmente executadas, trechos importantes dessas rodovias constituem-se como os principais gargalos rodoviários de Mato Grosso, pois são considerados críticos pela sobrecarga sobre a via. Nesse contexto, os estudos referentes ao ano de 2011(CNI; CNA; MACROLOGÍSTICA, 2013) fornecem um quadro importante de análise das condições do tráfego. Os gargalos mais expressivos para aquele ano estão elencados a seguir:

- Trecho entre Lucas do Rio Verde e Posto Gil da BR-163 que possui uma capacidade de carga de 38,9 toneladas por dia e recebe uma carga diária de 83 mil toneladas, apresentando uma sobrecarga de $213,5 \%$;

- Trecho entre Rondonópolis e Alto Araguaia, sobre a BR-364, recebe uma carga diária de 78,7 mil toneladas por dia, quando está adequada para suportar 38,9 toneladas por dia. Assim, possui uma sobrecarga de 202,5\%. Porém, a partir do final de 2013, quando o terminal da ALL de Rondonópolis entrou em operação, o fluxo deste trecho foi reduzido substancialmente, pois o novo terminal realocou o fluxo para a BR-163 nas proximidades de Rondonópolis;

- Trecho entre o Posto Gil e Cuiabá, coincidente entre as BRs 163 e 364, é uma sequência do trecho entre Lucas do Rio Verde e o Posto Gil. Possui uma capacidade 
de 38,6 mil toneladas por dia, mas recebe 72,8 mil toneladas diariamente, apresentando um uso de $188,3 \%$ da capacidade;

- Trecho entre Cuiabá e Rondonópolis, também coincidente das BRs 163 e 364, recebe 70,6 mil toneladas por dia, quando suporta apenas 38,9 mil toneladas diariamente. A sobrecarga é de $181,6 \%$.

Concorrem para a redução da fluidez rodoviária as travessias urbanas nos trechos das principais rodovias federais. Este fato decorre da inexistência de anéis rodoviários nos trechos mais críticos, o que provoca perturbações urbanas como os congestionamentos, concorrência entre veículos de carga e de passeio que transitam nas cidades, bem como favorecem para a ocorrência de acidentes. Pois, nestes trechos de travessias urbanas não ocorrem restrições para o trânsito de veículos de cargas em horários estabelecidos, apenas controle de velocidade por meio de lombadas eletrônicas e ondulações transversais.

Outro destaque no trecho que compreende as rodovias BR-163 e BR-364 é a duplicação que se encontra em execução pelo governo federal, por meio do DNIT, e da Concessionária Rota Oeste, vencedora do leilão da BR-163. Como as duas rodovias são coincidentes a partir de Rondonópolis até o Posto Gil, no município de Diamantino, as ações empreendidas, de revitalização e duplicação, contribuem no período de execução das obras para a lentidão do trânsito (por meio do mecanismo de Siga e Pare, quando apenas partes da pista de rolamento é liberada para o tráfego em um dos sentidos), principalmente do trecho entre Rondonópolis e Cuiabá, as duas principais cidades de Mato Grosso. No entanto, a duplicação em efetivação entre o terminal da ALL até o local chamado Trevão (entroncamento das duas rodovias federais), proporcionará uma redução considerável do congestionamento em Rondonópolis, algo que não foi efetivado em Alto Araguaia.

O Mapa 10, apresenta os gargalos do modal rodoviário em Mato Grosso, com base nos estudos da Macrologística, em que é necessário considerarmos o período (2011) e as mudanças que já ocorreram, principalmente da redução do fluxo entre Rondonópolis e Alto Araguaia. 
Mapa 10 - Gargalos do setor rodoviário em Mato Grosso em 2011

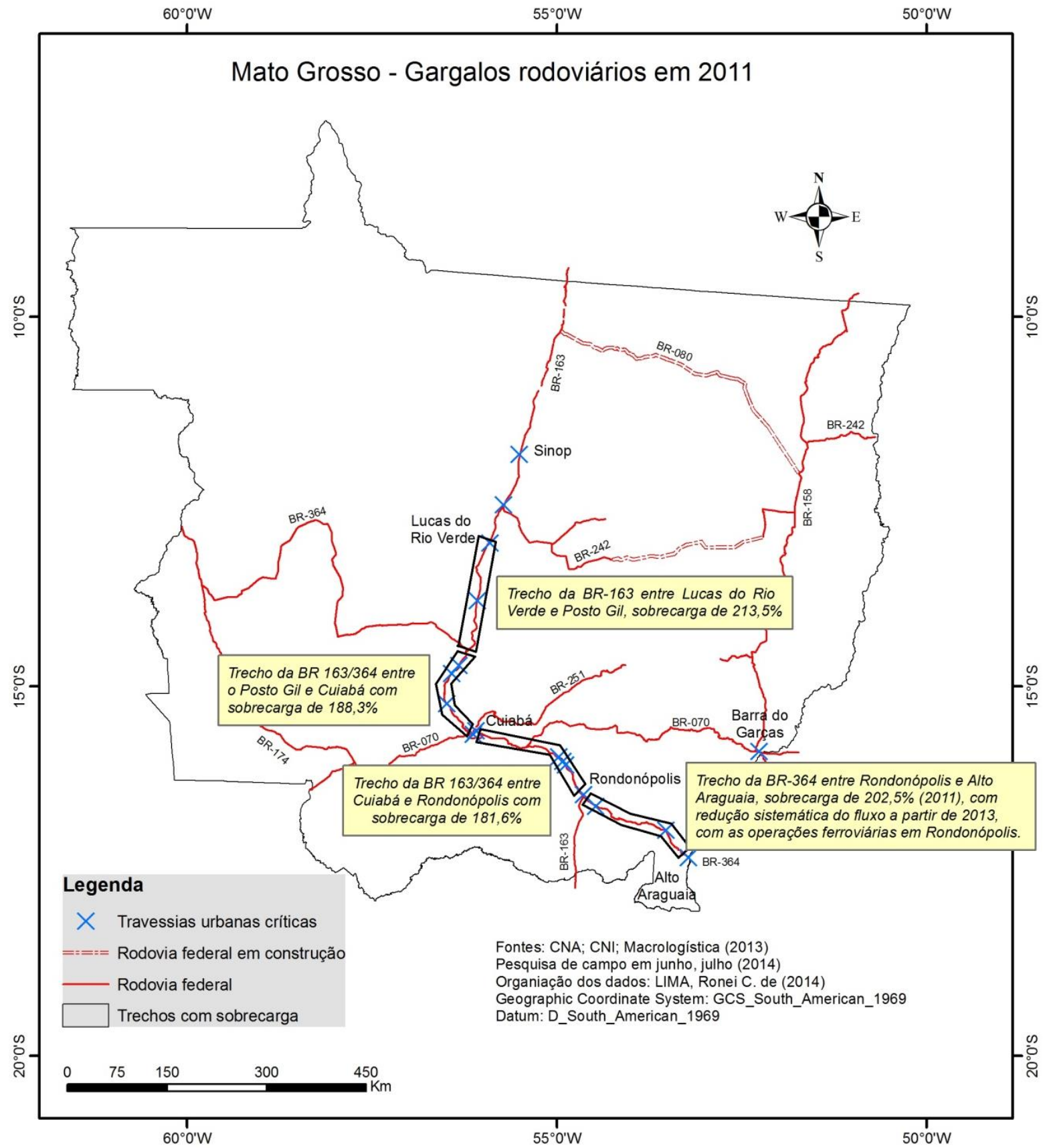

Fontes: CNA; CNI; Macrologística, 2013 e Trabalho de campo, 2014 
A criação dos gargalos destacados no Mapa 10, evidencia o efeito de corredor de exportações no estado de Mato Grosso, criando um verdadeiro funil, em que as áreas de produção destinam seus produtos para as principais vias de acesso aos mercados consumidores, principalmente para os portos exportadores.

Mas, a inversão da logística de transportes em curso poderá reduzir a movimentação de commodities nos trechos entre Lucas do Rio Verde e Rondonópolis no sentido Norte-Sul, mas deverá manter, ou ainda intensificar, os fluxos de insumos exigidos pelo agronegócio redundando em acréscimos destes no sentido Sul-Norte.

\subsubsection{Modal ferroviário}

Considerando que as cargas transportadas a partir de Mato Grosso são essencialmente de granéis sólidos e líquidos (grãos, farelos, biodiesel e etanol), fica evidente a necessidade do uso de modais mais adequados para o seu transporte, quais sejam, as ferrovias e as hidrovias. A partir do ano 2000, com a instalação do terminal ferroviário da ALLMN no município de Alto Taquari em Mato Grosso, este estado passou a contar em seu território com essa alternativa de transportes.

Com a expansão da rede ferroviária posteriormente até Alto Araguaia, Itiquira e finalmente em Rondonópolis, o modal ferroviário se tornou estratégico para o escoamento dos produtos voltados à exportação, principalmente de grãos (soja e milho) e farelo de soja, que são direcionados ao porto de Santos. Segundo argumenta Lacerda (2005, p. 196), o porto de Santos tem como sua principal região de influência ferroviária um conjunto de locais nos quais “[...] a distância ferroviária até Santos é menor do que a distância até portos alternativos, como acontece com a maior parte dos Estados de São Paulo, Mato Grosso do Sul, Mato Grosso, partes de Goiás e Triângulo Mineiro".

Dessa forma, portos normalmente acessados por via rodoviária pela produção matogrossense, como o porto de Paranaguá, localizado no estado do Paraná, são inviabilizados como opção ferroviária porque a rigidez da malha impede uma maior articulação entre as vias férreas. 
Nesse contexto, cria-se um corredor quase exclusivo para o porto de Santos. Com isso esse porto recebe investimentos no transporte de granéis sólidos, como os terminais de grãos, efetivados pelas principais operadoras de logística e do agronegócio. Assim, as empresas Bunge, Amaggi e ALL, com Terminal de Granéis do Guarujá (TGG); a CGG, com o TGRÃO; a ALL e a Caramuru, com os terminais próprios nas instalações portuárias de Santos; e a Cargill e a LDC, com o Terminal Exportador do Guarujá (TEG), garantem ao porto de Santos o maior fluxo de exportações de grãos do agronegócio brasileiro, assegurando a esse porto a maior participação entre os portos nacionais na movimentação de commodities agrícolas e consolidando a característica extrovertida do sistema ferroviário nacional.

No entanto, como as cargas transportadas se juntam àquelas transportadas pela malha paulista da ALL, a confluência provoca um adensamento de cargas transportadas em níveis que a estrutura ferroviária tem dificuldade de atender.

Para solucionar tal problema, foi proposta a duplicação da ferrovia ALLMP entre Itirapina/Evangelista de Souza e Paratinga/Perequê no estado de São Paulo, favorecendo o acesso ao porto de Santos (RUMO ALL, 2014). No Mapa 11, é possível observar os trechos onde ocorrem os principais gargalos e que demandam a duplicação mais urgentemente.

Este gargalo se agravou pelo crescimento do transporte de cargas via ferrovias, principalmente com a ligação da ALLMN à ALLMP. Assim, o volume de mercadorias transportadas de Mato Grosso e Mato Grosso do Sul, da ordem de 20.594 milhões de toneladas por quilômetro útil (TKU) em 2013, se somou aos 3.912 milhões de TKUs da malha paulista no mesmo ano (BRASIL, 2014e p. 5) aumentando consideravelmente os fluxos ferroviários em direção ao porto de Santos por este modal.

Completando o quadro de impedimentos à melhor fluidez, temos ainda as interrupções nos fluxos ferroviários da ALL no trecho paulista por motivos como: a passagem de níveis, a invasão de domínio da ferrovia em cidades e a demora nas atividades de carga e descarga nos portos. 


\section{Mapa 11 - Ferrovia ALLMN/ALLMP e o gargalo ferroviário}

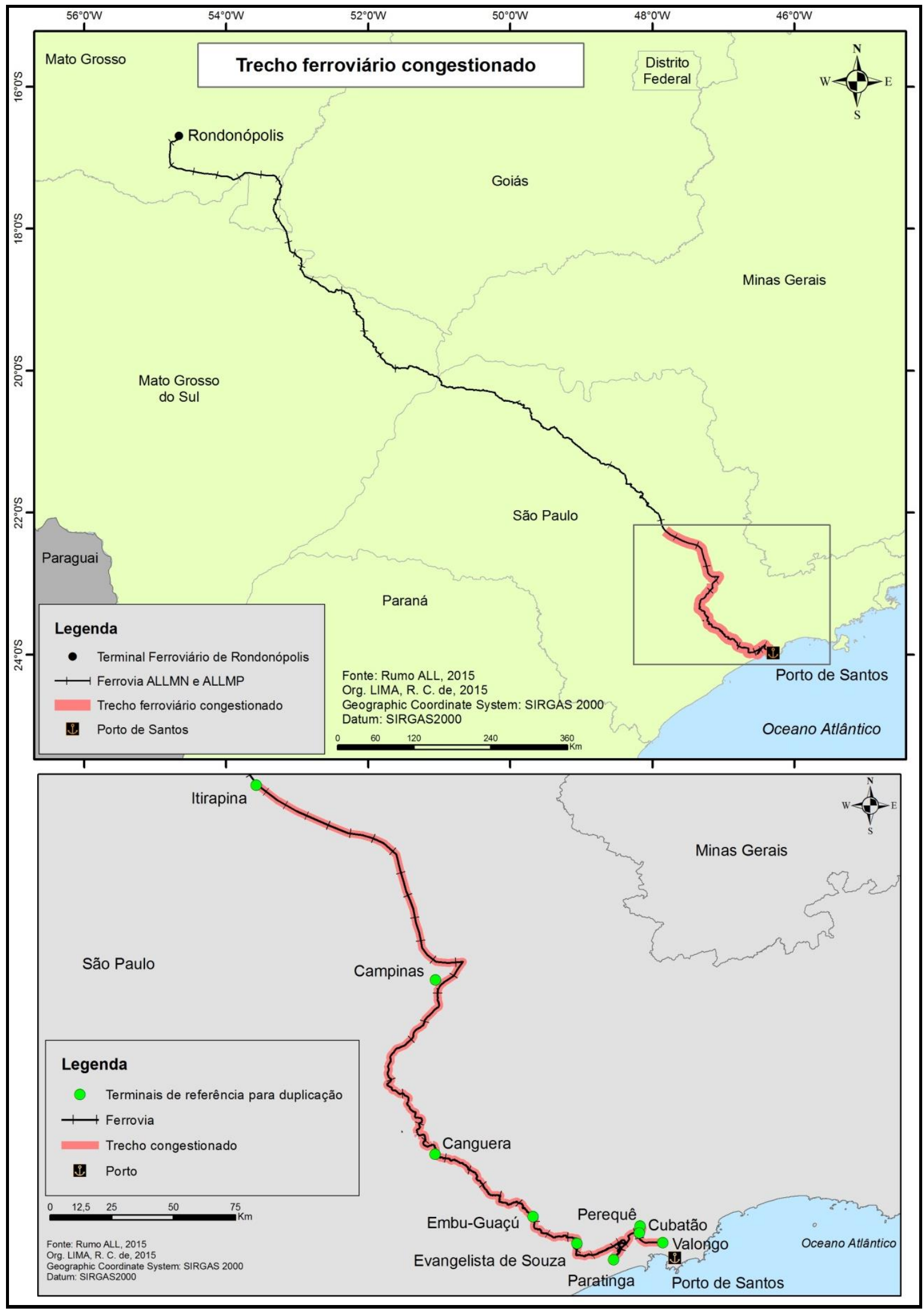

Fonte: Rumo ALL, 2015

Org.: LIMA, R. C. de, 2015 
Outro gargalo do setor está mais vinculado às questões políticas do que operacionais, pois se trata da regulação referente às concessões de novas ferrovias, como no caso da Ferrovia de Integração do Centro-Oeste (FICO).

Segundo Silveira (2013, p. 47) busca-se um novo modelo de administração das ferrovias no Brasil que visa a "quebra do monopólio na oferta de serviços ferroviários pela garantia de direito de passagem para todos os transportadores", com isto a empresa que ganhar a concessão não poderá interferir no fluxo ferroviário, mas terá o compromisso da manutenção das linhas ferroviárias de forma que os fluxos sejam otimizados e haja uma redução gradativa das tarifas. Dessa forma, as ferrovias poderão se tornar mais competitivas.

De acordo com o Brasil (2014h) a responsabilidade de planejar, gerir, construir e alocar a capacidade das ferrovias passa a ser da Valec Engenharia, Construções e Ferrovias S/A, que é uma empresa pública vinculada ao Ministério dos Transportes. Sob sua reponsabilidade estão empreendimentos importantes, como: EF-151 (Ferrovia Norte Sul), EF232 (Ligação da Ferrovia Norte Sul com a Transnordestina), EF-267 (Ferrovia do Pantanal), EF-280/499/498 (Corredor Ferroviário de Santa Cantarina), EF-334 (Ferrovia da Integração Oeste Leste), EF-354 (Ferrovia Transcontinental - Ferrovia de Integração Centro-Oeste (FICO)).

No entanto, como a Valec passa a ser a responsável pelo repasse ao concessionário da venda do direito de passagem, já que toda a capacidade operacional que for contratada será adquirida pela Valec, fica a dúvida em relação às reais condições da empresa de manter os acordos, inibindo os investimentos, sendo seus efeitos conhecidos como o "risco Valec".

\subsubsection{Modal hidroviário}

A necessidade de redução constante de custos, uma das estratégias importantes e intrínsecas à logística de transportes, depende da intermodalidade, pois para cada tipo de carga e para cada distância existe um modal mais adequado. Apesar da onipresença do modal rodoviário no transporte de cargas no Brasil, observa-se uma evolução dos modais ferroviário 
e hidroviário, em que pese ser uma evolução tímida e não sincronizada com o aumento substancial das produções agrícola e mineral que são mais adequadas a estes modais.

Pela posição geográfica ocupada por Mato Grosso, distante dos portos exportadores, é premente a utilização de ferrovias e hidrovias para o transporte de granéis sólidos, como os grãos, para uma redução dos custos de transportes e maior competitividade da produção.

Para Felipe Junior (2011, p. 518) existem vantagens substanciais do transporte fluvial em relação ao transporte ferroviário e, principalmente, sobre o transporte rodoviário. $\mathrm{O}$ autor considera as vantagens sob os seguintes aspectos: o econômico, pois apresenta um menor custo de frete e grande capacidade de cargas; quanto ao transporte, por possuir menor incidência de acidentes e maior constância ao longo do trajeto, o que é adequado para cargas em granéis sólidos e líquidos; em relação ao meio ambiente, pois é menos poluente. Finaliza dizendo que, quanto à estrutura de funcionamento, demanda a intermodalidade.

No entanto, mesmo sendo a melhor alternativa para as cargas originadas em Mato Grosso, o uso desse modal de transportes é reduzido pela inércia dos agentes responsáveis pela criação das infraestruturas necessárias para a plena utilização deste modal. Excetuandose a hidrovia do rio Madeira, que atende a produção do Oeste mato-grossense e o início das atividades pelo rio Tapajós, as outras possibilidades não estão acessíveis, e por isto constituem-se em gargalos para o escoamento da produção tendo em vista a demanda crescente por novas rotas de circulação.

Em relação às hidrovias, apesar de apresentarem elevadas taxas de retorno econômico conforme aponta o relatório final de 2012 do PNLT, inclusive com prazos para implantação até 2015, observa-se na realidade que os projetos mesmo considerados prioritários visam a atender um horizonte de longo prazo (mas precisamente 2030) como a utilização da hidrovia Tocantins-Araguaia, no rio Tocantins, a partir do terminal interior de Miracema do Tocantins (TO). Mas, as condições de navegabilidade do rio Tocantins variam de acordo com o regime hídrico, além de possuir interferências naturais, como os pedrais e os bancos de areia, tornando necessária a construção de três hidrelétricas com eclusas (Marabá, Serra Quebrada e Tupiratins, além da construção de um sistema de eclusas na Usina Hidrelétrica de Estreito) para regularizar o curso do rio e permitir a navegação (BRASIL, 2013, p. 102).

A hidrovia Tocantins-Araguaia poderá atender a crescente produção de grãos do nordeste de Mato Grosso, principal área de expansão agrícola do estado. No entanto, a 
hidrovia Juruena-Teles Pires-Tapajós é uma alternativa mais próxima de atender a necessidade de novas rotas de escoamento de commodities, estando em consonância com o anseio da inversão da logística de transportes para o Norte.

Inclusa no vetor Amazônico do PNLT, a hidrovia Teles Pires-Juruena-Tapajós, apresenta elevada taxa de retorno econômico, acima de $24 \%$ - conforme já explicitado no Quadro 4 - e poderá atender a uma demanda reprimida da crescente produção da área consolidada e concentrada da soja em Mato Grosso, localizada no eixo da BR-163 no MédioNorte, cuja busca pela alternativa já é uma realidade a partir de Miritituba/Itaituba no Pará. Pois, essa área produtora prescinde da redução de custos, algo possível com o modal hidroviário.

No entanto, o seu potencial de uso para a navegação comercial depende de intervenções no seu curso e depende da construção de eclusas nas hidrelétricas previstas para este sistema hidroviário. Segundo o Brasil (2013, p. 92) no trecho entre Itaituba e Cachoeira Rasteira estão previstas a construção de três usinas hidrelétricas (São Luís do Tapajós, Jatobá e Chacorão), mas a “[...] A construção dessas usinas hidrelétricas tem encontrado desafios para ter o apoio das comunidades locais, especialmente das comunidades indígenas próximas a Jacareacanga [...]”, pois no trecho encontram-se terras indígenas regularizadas, aprovadas e outras já delimitadas pela Fundação Nacional do Índio - FUNAI.

À montante de Cachoeira Rasteira, onde iniciaria a hidrovia do Tapajós em Mato Grosso com destino à Miritituba/Itaituba e Santarém, segundo o Brasil (2014i) estão previstas as seguintes usinas hidrelétricas, com recursos do PAC, na bacia do rio Teles Pires: Usina Hidrelétrica (UHE) de Sinop, UHE São Manoel, UHE Teles Pires e UHE Colíder. O Movimento Pró-Logística (2013) vislumbra a possibilidade de aproveitamento da hidrovia do Teles Pires a partir de Sinop, inclusive criando modelos de alcance de escoamento da produção do Médio-Norte desde o porto de Sinop. As hidrelétricas previstas poderiam incluir eclusas para permitir a navegação comercial, desonerando substancialmente os custos com transportes.

Mas, por ser um projeto integrado, caso as usinas no território paraense sejam impedidas de execução, como é o caso da UHE de Chacorão, localizada em terras indígenas, ocorrerá uma interrupção de fluxo. Além das questões legais que permeiam o projeto hidroviário do Teles Pires-Tapajós, há os impedimentos naturais que demandam correções no curso do rio, sinalização e liberação de áreas impeditivas como os pedrais e as corredeiras 
existentes. A partir de dados da WWF-Brasil (2015), o Quadro 11, destaca os territórios afetados nas bacias do Teles Pires e do Tapajós - em decorrência das obras e projetos de construção das usinas em seus vários estágios, e também a produção de energia estimada.

\section{Quadro 11 - Usinas Hidrelétricas selecionadas nas bacias dos rios Teles Pires e Tapajós}

\begin{tabular}{|c|c|c|c|c|c|}
\hline \multirow{2}{*}{ UHE } & \multirow{2}{*}{ Bacia } & \multicolumn{3}{|c|}{$\begin{array}{c}\text { Áreas afetadas } \\
\text { (em hectares) }\end{array}$} & $\begin{array}{c}\text { Produção } \\
\text { de energia } \\
\text { (mW) }\end{array}$ \\
\cline { 3 - 5 } & & $\begin{array}{c}\text { Terras } \\
\text { Indígenas } \\
\text { (TI) }\end{array}$ & $\begin{array}{c}\text { Unidades de } \\
\text { conservação } \\
\text { (UC) }\end{array}$ & $\begin{array}{c}\text { Área } \\
\text { Inundada }\end{array}$ & \\
\hline Magessi & Teles Pires & 0 & $\begin{array}{c}781 \\
\text { Ref. 01 U.C. }\end{array}$ & 6.393 & 53 \\
\hline Sinop & Teles Pires & 0 & 0 & 32.963 & 461 \\
\hline Colíder & Teles Pires & 0 & 0 & 12.334 & 342 \\
\hline Teles Pires & Teles Pires & 0 & 0 & 14.585 & 1.820 \\
\hline São Manoel & Teles Pires & 0 & 0 & 5.708 & 747 \\
\hline Chacorão & Tapajós & 12.682 & $\begin{array}{c}2.931 \\
\text { Ref. 01 U.C }\end{array}$ & 62.527 & 3.336 \\
\hline Jatobá & Tapajós & 0 & $\begin{array}{c}15.510 \\
\text { Ref. 02 U.C. }\end{array}$ & 64.876 & 2.338 \\
\hline São Luiz do & Tapajós & 0 & $\begin{array}{c}31.662 \\
\text { Ref. 02 U.C. }\end{array}$ & 73.242 & 6.133 \\
\hline
\end{tabular}

Fonte: WWW-Brasil. Hidrelétricas na bacia do Tapajós (2015)

Os impedimentos legais apontam dificuldades para a execução da UHE de Chacorão, inviabilizando a proposta do setor produtivo de uma ligação hidroviária desde as áreas produtoras aos portos de Miritituba (PA) e Santarém (PA). Portanto, a plena execução das alterações antrópicas nos cursos dos rios depende de acordos que implicam questões ambientais e sociais, tornadas tão importantes quanto as questões econômicas postas, demonstrando a existência de resistências na produção do território, próprias do embate entre interesses conflitantes.

É o que ocorre, da mesma forma, com a hidrovia do Paraguai-Paraná (HPP) cujos interesses divergentes entre os setores corporativos do agronegócio e as entidades ambientalistas de defesa do Pantanal promovem um conflito declarado.

Nesse sentido, Leão, El Hage e Bampi (2013, p. 64) argumentam que se por um lado há uma grande pressão por parte dos setores econômicos para que a hidrovia possa ser implantada na sua plenitude, de outro lado "[...] os movimentos sociais ainda estão ativos e relativamente informados sobre as mais diversas problemáticas que envolvem a HPP e demais assuntos sobre o ecossistema pantaneiro". 
Os autores informam que as articulações político-econômicas existentes para a ampliação do transporte fluvial de mercadorias desde Cáceres e a possibilidade de asfaltamento da rodovia de acesso à fazenda Santo Antônio das Lendas, onde seria construído o porto de Morrinhos, é um alerta para os movimentos sociais que resistem à condução do processo de reestruturação desses espaços.

O problema central é a inclusão de um sistema de transportes, com alta frequência de uso, em trechos do rio Paraguai que são caracterizados por condições físicas pouco propícias para grandes embarcações, principalmente na época da seca. Para que seja possível um fluxo comercial na escala pretendida pelo setor corporativo, alterações significativas terão que ser efetivadas.

De acordo com o Brasil (2013, p. 118-119) consta no Plano Hidroviário Estratégico as seguintes considerações sobre as condições da hidrovia do rio Paraguai:

O trecho entre Corumbá (MS)/Ladário (MS) e Cáceres (MT) apresenta meandros e estreitos com mais intensidade, e as condições de navegabilidade são afetadas por acúmulos de sedimentos, que resultam em alguns segmentos com pouca profundidade do escoamento, restringindo a navegação, dependendo da estação hidrológica. Esses aspectos afetam consideravelmente as condições atuais de navegação no rio, onde, no passado, eram navegados comboios $2 \times 3$. Atualmente, a navegação nesse trecho está limitada ao turismo.

Para adaptar as condições do rio Paraguai às demandas corporativas, seriam necessárias mudanças de alto impacto no seu curso no trecho da hidrovia. O Quadro 12, apresenta as principais intervenções e os custos estimados para reduzir os gargalos existentes na hidrovia do rio Paraguai em Mato Grosso e Mato Grosso do Sul. 
Quadro 12 - Intervenções e custos da hidrovia do rio Paraguai em Mato Grosso e Mato Grosso do Sul

\begin{tabular}{|c|c|c|c|}
\hline Área de ação & Intervenções no rio Paraguai & $\begin{array}{l}\text { Extensão } \\
(\mathrm{Km})\end{array}$ & $\begin{array}{l}\text { Custo } \\
\text { (milhões R\$) }\end{array}$ \\
\hline \multirow[t]{2}{*}{$\begin{array}{l}\text { Da foz do rio Apa até } \\
\text { Corumbá (MS)/Ladário (MS) }\end{array}$} & $\begin{array}{l}\text { - Adequação do canal do rio e } \\
\text { sinalização; }\end{array}$ & \multirow{2}{*}{570} & 50 \\
\hline & $\begin{array}{l}\text { - Alargamento do vão das pontes BR- } \\
262 \text { e ferroviária Eurico Gaspar Dutra }\end{array}$ & & 200 \\
\hline $\begin{array}{l}\text { De Corumbá (MS)/ Ladário } \\
\text { (MS) até Cáceres (MT) }\end{array}$ & $\begin{array}{l}\text { Retificação do leito do rio, dragagem, } \\
\text { derrocamento, regularização do rio e } \\
\text { sinalização }\end{array}$ & 640 & 2.048 \\
\hline TOTAL & & 1.210 & 2.298 \\
\hline
\end{tabular}

Fonte: Plano Hidroviário Estratégico, 2013.

No entanto, poucas intervenções estão sendo efetivadas tendo em vista as questões de ordem legal impostas (processo de impedimento de obras sem estudos de impactos socioambientais prévios e abrangentes). Assim, as intervenções são pontuais, tais como dragagens, dragagens de manutenção e sinalização (BRASIL, 2014j).

A desativação atual do terminal de grãos do porto de Cáceres (Figura 13), reflexo dos impasses existentes, imobiliza uma das estratégias corporativas do agronegócio como opção para o escoamento principalmente da produção das regiões Oeste e Centro-Norte de Mato Grosso.

Ao mesmo tempo, a hidrovia do Paraguai nunca representou até então uma via preferencial das exportações do agronegócio mato-grossense, principalmente pela falta de infraestrutura adequada, pois a movimentação de commodities para o exterior alcançou em dezessete anos (de 1993 a 2009) somente 1.260.000 toneladas de soja, 23.587 toneladas de bagaços de soja e 1.370 toneladas de milho em grão, não havendo movimentação registrada nos demais anos (BRASIL, 2015). No mesmo período foram registradas exportações por via rodoviária e aérea de produtos como algodão, sementes de milho e milho em grão num total de 7.471 toneladas que utilizaram o porto para efetivar as operações internacionais. 
Figura 13 - Terminais de grãos de Cáceres

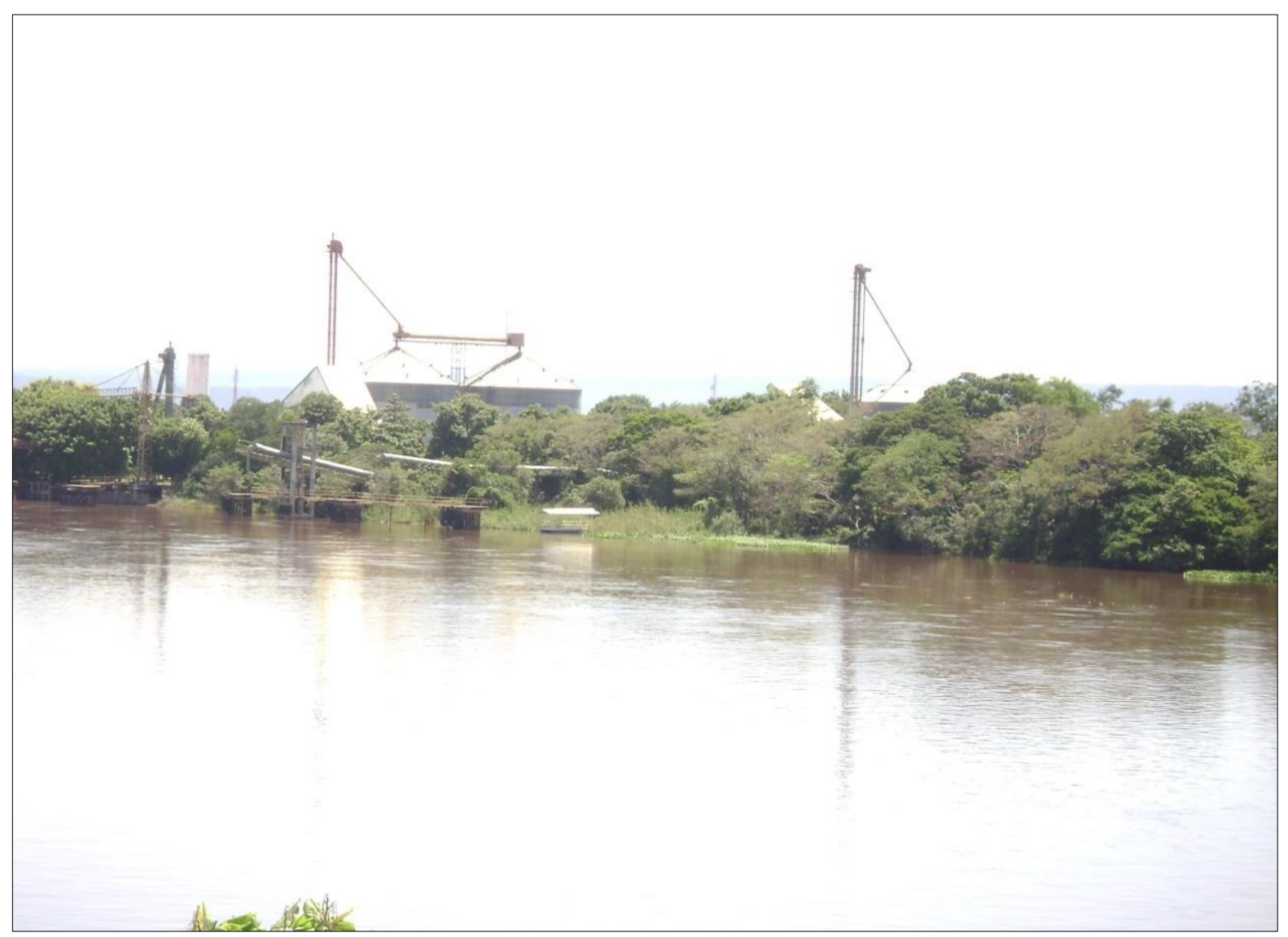

Fonte: LIMA, Ronei C. de, 2015 (Trabalho de campo em 08 de janeiro de 2015).

Diante desse quadro, a estratégia adotada pelo setor é de envidar esforços para a construção do porto de Morrinhos (Santo Antônio das Lendas), localizado à jusante do porto de Cáceres a cerca de 80 quilômetros de distância conforme pode ser observado no Mapa 12, e que poderia possibilitar novas rotas de escoamento conforme aponta o Movimento PróLogística (2013). 
Mapa 12 - Hidrovia do Paraguai em Mato Grosso e as rotas projetadas pelo agronegócio

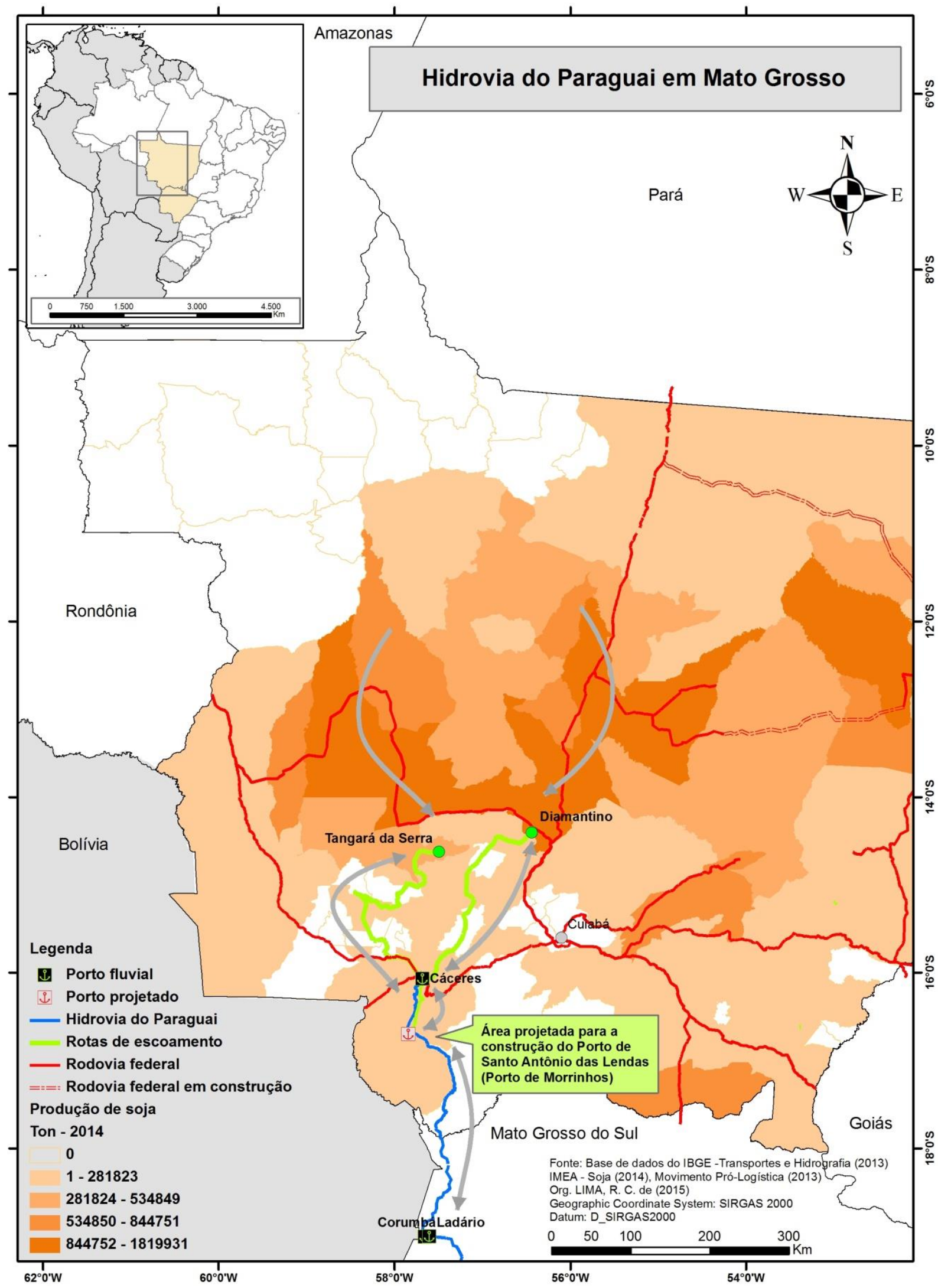

Fonte: Trabalho de campo (janeiro de 2015); IMEA - Soja (2014), IBGE - Transportes e Hidrografia (2013), Movimento Pró-Logística (2013); Org. LIMA, Ronei Coelho de, (2015) 
O municípios que teriam seus territórios atravessados pelos novos fluxos (Diamantino, Tangará da Serra, Cáceres, Arenápolis, Barra do Bugres, Rio Branco, Araputanga, Denise, Mirassol d’Oeste, Porto Estrela, Reserva do Cabaçal e São José dos Quatro Marcos) respondem por 10,1\% da população estimada de Mato Grosso para o ano de 2014 (IBGE, 2014c); por 5,7\% da soja produzida no estado em 2014 (IMEA, 2014), sendo que o município de Diamantino sozinho contribui com 4,4 \% desse total; 8,6\% do rebanho de bovinos, em que Cáceres responde por 3,4\% do total.

O conjunto dos municípios apresenta um Índice de Desenvolvimento Humano Municipal (IDHM) médio de 0,697, abaixo da média de Mato Grosso que é 0,725, de acordo com dados do Atlas do Desenvolvimento Humano (2013). Portanto, é uma área cujas características demandam de fato melhores condições de fluidez, porém as rotas traçadas possuem grandes possibilidades de criar o efeito túnel (VENCOVSKY; CASTILLO, 2007), apenas atravessando as áreas e pouco contribuindo, exceto para a cidade de Cáceres que funcionaria como um terminal e atrairia mais investimentos.

Porém, o empreendimento foi embargado pela justiça, por força dos movimentos sociais e do Ministério Público Estadual que impetrou ação contra o licenciamento efetivado pela Fundação Estadual do Meio Ambiente de Mato Grosso (FEMA), quando a competência cabia ao Instituto Brasileiro do Meio Ambiente e dos Recursos Naturais Renováveis (IBAMA).

Para os representantes do agronegócio, com a implementação do porto de Morrinhos, os meandros acentuados existentes seriam evitados, logo a navegação por barcaças poderia ser efetivado novamente em escala ampliada. A desativação do terminal de grãos de Cáceres e o embargo à construção do porto de Morrinhos se tornam gargalos logísticos do setor hidroviário em Mato Grosso.

Em suma, verifica-se que os principais gargalos logísticos dos modais rodoviário, ferroviário e hidroviário encontram-se diretamente relacionados às necessidades da reprodução do capital, exigente de reduções de custos frente à competitividade inerente à integração com os mercados globais.

As interrupções dos fluxos, ou sua lentidão forçada, resultam de gargalos que se materializam nas formas apresentadas, mas também por problemas de ordem operacional, 
normativa, ambiental e social, que resultam das disputas sociais no território, mesmo que aos poucos os interesses corporativos tendam a prevalecer.

A busca do setor produtivo por competitividade, que pode ser entendida entre outras pela adoção sistemática da intermodalidade e multimodalidade do setor de transportes, implica na expansão e integração desse setor, mas, como argumentam Rondinelli e Berry (2000) a expansão, que proporciona a integração, complexifica os impactos dos sistemas de transportes sobre o ambiente, não sendo possível resolver as questões apenas com a conformidade regulatória. Para os autores ações provenientes da gestão proativa das indústrias de transportes são necessárias para reduzir os impactos ambientais.

Mas, para o setor corporativo a busca por novas alternativas, que denominamos de novas dinâmicas territoriais do agronegócio, como a saída para o Norte (Mapa 13), representa a flexibilidade operacional da logística de transportes desse setor, já que a intensificação dos fluxos gerados não é acompanhada na mesma proporção pelas infraestruturas de escoamento, gerando certa irracionalidade. Dessa forma, apresentam desvantagens quanto aos custos e quanto ao tempo de realização do processo de produção-distribuição-circulação-consumo.

Com isto a competitividade conseguida na produção, pelos altos níveis de produtividade, é neutralizada pela existência de gargalos logísticos que impedem uma fluidez necessária ao capital em seu processo de reprodução, exigindo uma concentração proposital de interesses do setor corporativo na resolução dos problemas causados.

Diante do exposto, concordamos com Castillo (2011, p. 339) quando este afirma que:

\begin{abstract}
A logística torna-se, assim, a expressão de uma organização e de um uso do território, voltados, na linguagem corporativa (que também é da grande mídia), para a superação dos gargalos da circulação, para evitar os "apagões" (portuário, ferroviário, de armazenamento, etc.) e para reduzir o "custo país.”.
\end{abstract}

Como os custos operacionais são repassados ao produtor, visto que nos preços pagos às commodities já constam os custos de transportes, as tradings são prejudicadas pela demora da realização do processo de circulação, enquanto que o ônus financeiro das transações recai sobre os produtores rurais, daí a crise do agronegócio e a necessidade de novas estratégias como a agregação de valor à produção. 


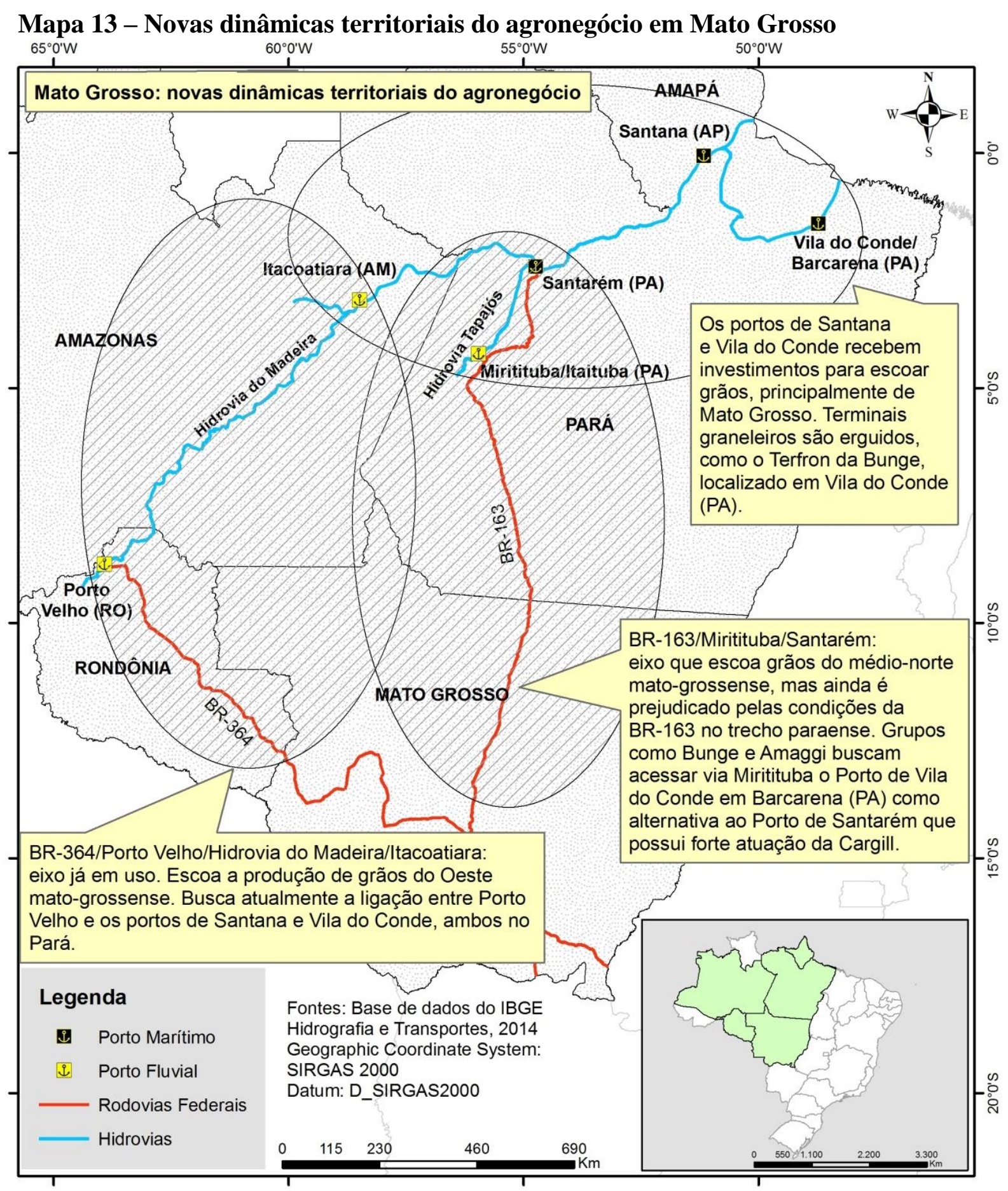

Fonte: Base de dados do IBGE - Hidrografia e Transportes (2014)

Ao consideramos essas novas dinâmicas territoriais em seu conjunto, é possível perceber que um jogo de forças se estabelece entre agentes corporativos diversos, implicando na adoção de estratégias para manter a condição de competitividade em face das novas demandas do mercado. A pujança da Região Concentrada, principalmente do Sudeste e Sul do Brasil, depende em parte da manutenção da condição de hegemonia, hoje mais relativa, em relação à sua área de influência. 
No horizonte do agronegócio mato-grossense, cujos principais agentes são as tradings e o setor produtivo no seu conjunto, o caminho para a manutenção da competitividade se dirige para o Arco Norte (Norte e Nordeste), pois a redução de custos esperada proporcionará uma maior reprodução do capital. No entanto, a dinâmica de reestruturação territorial ampliada do agronegócio, com o transbordamento principalmente para as áreas amazônicas, principalmente em seu atravessamento físico (hidrovias, rodovias e ferrovias) e a consolidação de transformações na reprodução social das áreas envolvidas (estações de transbordo, portos) com a instalação de fixos diversos, não está voltada apenas nessa direção.

As grandes corporações, chamadas no mercado de players, direcionam investimentos em rotas diversas, pois não podem deixar de trabalhar com a perspectiva de redes de fluxos, que devem ser diversificadas para evitar estrangulamentos em decorrência de eventos cujo controle não depende diretamente delas. Assim, ao efetivarem vultosos investimentos em terminais de cargas localizados nos principais portos do país, assim como em armazéns e plantas de beneficiamento, estrategicamente situados nas proximidades das vias de escoamento (principais e secundárias) e das áreas de produção, busca-se diversificar as rotas, para não se tornarem reféns de um único fluxo, até porque a produção se espalha por amplas áreas, assim como o mercado consumidor caracterizado pelas longas distâncias.

A condição geográfica de Mato Grosso, central em sua localização e longe dos mercados, exige a utilização racional dos recursos de transportes envolvidos. Se inicialmente essa possibilidade inexistia, visto não haver alternativas ao transporte rodoviário, a atual conjuntura já permite uma maior diversificação de rotas. A intermodalidade tão pretendida pelo setor corporativo enfim toma corpo, e a ligação entre os modais rodoviário e ferroviário já é uma realidade no território mato-grossense (Rondonópolis, Itiquira, Alto Araguaia e Alto Taquari), mas não atendem aos interesses dos produtores das áreas mais dinâmicas, localizadas no Médio-Norte, que ainda são oneradas pela maior distância.

A inoperância da rota hidroviária do Paraguai, a partir de Cáceres, impede a articulação rodovia e hidrovia em terras mato-grossenses. Esse processo, já consolidado na hidrovia do Madeira, a partir de Porto Velho, agora é acompanhado pela utilização da hidrovia do Tapajós, no Pará. Essas dinâmicas podem ser constatadas no Mapa 14, que trás uma síntese provisória do processo, com a representação das principais rotas adotadas pelo setor corporativo do agronegócio. 
Mapa 14 - A logística de transportes do agronegócio mato-grossense

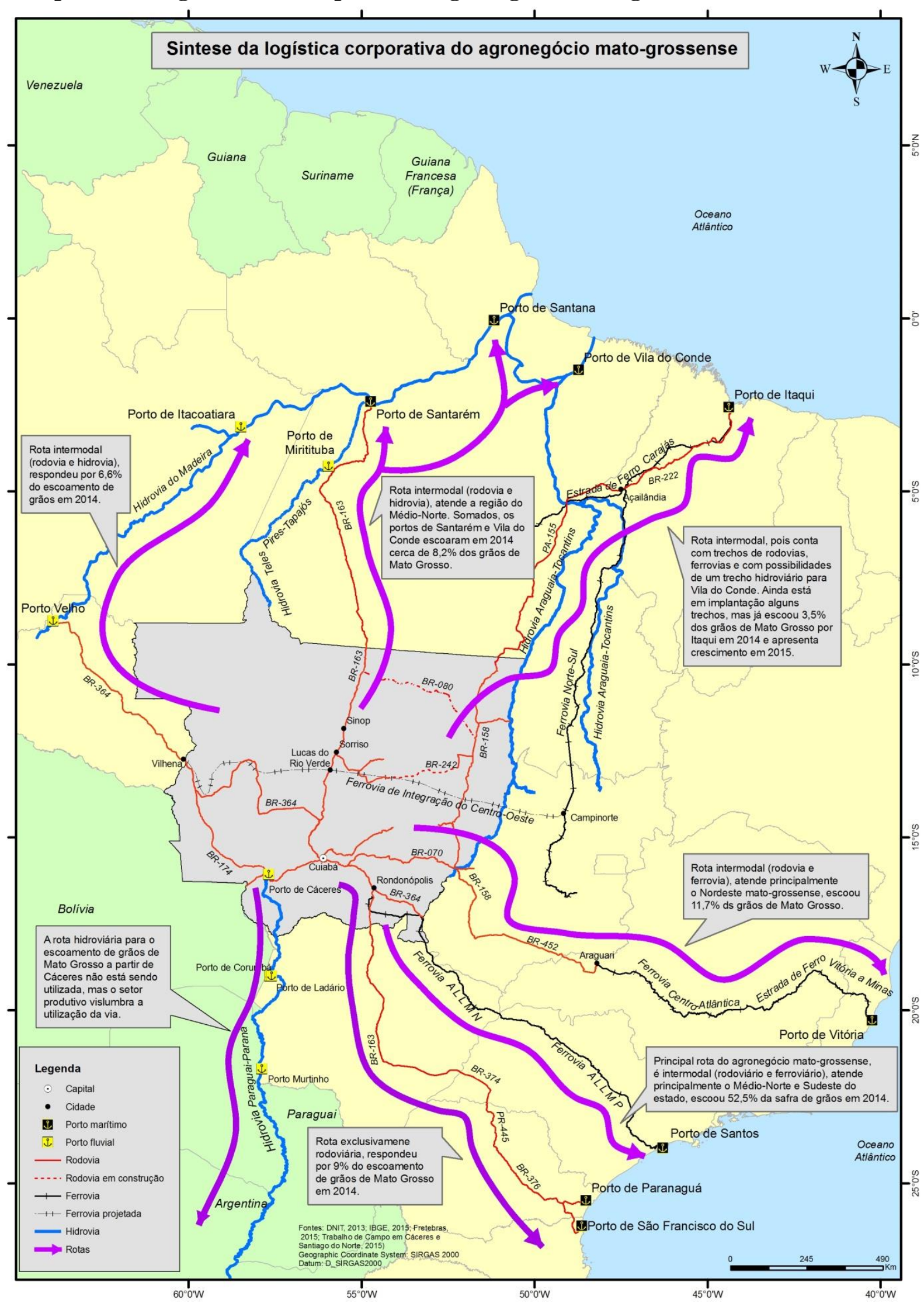

Fonte: IBGE, 2015; DNIT, 2013; Fretebras, 2015; Trabalhos de campo $(2014,2015)$ 
Dispostas espacialmente como tentáculos, as rotas novas e as tradicionais representam os fluxos racionalizados das grandes corporações do agronegócio, cujas lógicas, aparentemente individualizadas pela competição entre empresas, revelam estratégias conjuntas para otimizar processos e dividir os custos com capital fixo. Assim, a criação de novas empresas em conjunto, as joint ventures e as associações em projetos comuns demonstram certa convergência de interesses.

Como exemplos, podemos citar os investimentos conjuntos nos terminais em diversos portos e estações de transbordo, estrategicamente pensados para permitir um fluxo constante e seguro, elemento nodal no comércio internacional que é o fim maior da produção de commodities agrícolas.

Nesse contexto destacamos as seguintes parcerias: ALL, Bunge e Amaggi, no Terminal de Granéis do Guarujá - TGG, localizado no complexo portuário de Santos; ADM e Glencore, no Terminal de Grãos no porto de Vila do Conde, em Barcarena-PA; Agrosoja e Fiagril em um terminal de uso privativo - TUP, no porto de Santana-AP; Amaggi, LDC, CGG, Glencore e CHS, no Terminal de Grãos do Maranhão - TEGRAM; LDC e Cargill com parceira no Terminal Exportador do Guarujá - TEG.

Esses empreendimentos representam parte de um processo complexo, envolvendo empresas nacionais (Amaggi, Agrosoja, Fiagril e CGG) e transnacionais (ADM, Bunge, Glencore, LDC e Cargill), cooperativa (CHS) e do ramo da logística (ALL) demonstrando o estreitamento das relações entre as empresas, que apesar da concorrência, buscam garantias para a viabilidade dos negócios envolvidos, cujo fim maior é a obtenção de lucros e a acumulação de capital.

Toda essa dinâmica prescinde da territorialização do capital, da sua fixação em ativos que provocam rebatimentos no cotidiano dos lugares, tomados pela euforia dos investimentos prometidos (empregos, renda, impostos) e, por vezes, pela frustração dos projetos não realizados ou, ainda, por aqueles que mesmo sendo executados, não cumprem as expectativas geradas.

Nesses termos, entendemos que além das repercussões voltadas ao mundo corporativo e aos produtores rurais do agronegócio, há ainda os rebatimentos territoriais inerentes ao processo produtivo que exige novas funcionalidades aos lugares, estabelecendo novas relações entre o campo e a cidade, inclusive com a criação de municípios em Mato Grosso, 
cuja origem tem estreita relação com a dinâmica do agronegócio, visto que os seus desdobramentos afetam diversas esferas, como a econômica, a ambiental, a social, a cultural e a política.

Esses processos serão analisados no capítulo a seguir que trata da produção do espaço urbano mato-grossense, cuja organização interna e funcionamento foram afetados diretamente pelas dinâmicas do processo de reestruturação territorial. 


\section{A BASE URBANA DA PRODUÇÃO DO AGRONEGÓCIO MATO- GROSSENSE}

O processo de reestruturação do território mato-grossense efetivado pelo Estado culmina na sua integração aos mercados nacional e internacional, principalmente a partir de 1970, quando o movimento de modernização, em diversos níveis, favorece a implantação de um modelo agrário-exportador sobre novas bases. Esse modelo é agora ancorado na ciência, na técnica e na informação, criando uma produção espacial coerente com esse processo.

Isso ocorre porque atravessa várias escalas, fazendo parte de um processo de alcance mundial, apesar das especificidades locais. Os seus desdobramentos vão além da esfera econômica, pois repercute diretamente nas questões inerentes à reprodução da vida, como as de cunho cultural, pois são estabelecidos novos parâmetros de consumo que passam a imperar no cotidiano das pessoas, já que são criadas necessidades novas e novas relações no mercado de trabalho.

Neste sentido, Penna (2013, p. 211) faz uma consideração importante:

No contexto geral dos processos espaciais que ocorrem no Brasil é
importante destacar a crescente articulação do país à economia e à cultura
globalizada e a um modelo periférico de acumulação flexível. Enquanto se
organizam eixos de desenvolvimento do setor terciário moderno, tecnológico
e de alto padrão salarial, a flexibilização dos mercados de trabalho e a
informalidade das relações de emprego também constituem uma
característica importante deste processo.

A autora chama a atenção para a precarização dos vínculos empregatícios e pelo empobrecimento da massa de trabalhadores nesse processo, o que favorece a manutenção das desigualdades socioespaciais no que concerne à renda, repercutindo na ampliação das periferias das cidades. Entendemos que esses processos hodiernos resultam das condições em que as bases urbanas e de industrialização se efetivaram nos países periféricos ao se articularem com o mercado internacional de forma subordinada e tardia, logo decorrentes também de condições históricas pretéritas. 
Segundo Mandel (1982, p. 45), as relações de trabalho nos países periféricos são forçadas à precarização pelo aumento substancial do exército industrial de reserva e pela pouca eficácia dos setores representativos dos trabalhadores, cenário esse que contou ainda com condições políticas minimamente favoráveis, permitindo ao capital que compensasse "qualquer tendência no declínio da taxa de lucro ao assegurar um acréscimo ainda maior na taxa de mais-valia, através de uma redução significativa nos salários reais”. Baseando-se em dados da década de 1960, o autor informa que essa condição propiciou uma entrada mais efetiva de capitais estrangeiros em busca de altas taxas de lucros no Brasil proporcionadas, entre outros motivos, pelos baixos salários pagos. Portanto, a construção histórica das condições adversas do mercado de trabalho remonta ao conjunto de períodos que, somados, consolidam a condição de arrocho do trabalhador.

E, como duas faces de uma mesma moeda, enquanto a questão da precarização dos vínculos empregatícios é arrefecida no campo mato-grossense pela normatização que acompanha a integração (em consonância com a legislação trabalhista), de outro lado, onde a tecnificação da produção foi implantada, o novo modelo produtivo passou a exigir uma maior especialização da mão de obra que se torna formal, impedindo uma grande massa despreparada dos novos conhecimentos de acessar os empregos gerados.

Temos ainda, de outro lado, o fluxo daqueles impossibilitados de acessar a terra para o trabalho - pela concentração fundiária característica do modelo produtivo (ver Tabela 1) -, e que por não serem assimilados por esse mesmo modelo produtivo, migram para as cidades em busca de melhores condições. Mas, sem a qualificação necessária, engrossam as fileiras de desempregados e subocupados nas cidades de todo tamanho.

Quanto ao empobrecimento, como o mercado de trabalho é um custo para o empresário, a sua redução gradativa é um dos focos dos novos modelos de gestão corporativa para a manutenção de elevadas taxas médias de lucros, sob pena da impossibilidade da reprodução ampliada do capital.

São as novas relações - postas no contexto da flexibilização do mercado de trabalho, do regime de acumulação e dos processos produtivos - que direcionam mudanças espaciais importantes, como aquelas que discutimos acerca da reestruturação do território matogrossense frente às novas demandas que a integração passa a impor. 
Nesse contexto, passa a existir uma nova base urbana da produção agrícola, que é fomentada pela renda agropecuária e suas crescentes demandas por serviços e consumo (DINIZ, 2013), base essa que se territorializa nas cidades criadas e/ou refuncionalizadas que passam a dar suporte à produção tecnificada, cuja dinâmica atual pode ser considerada como hegemônica nos espaços luminosos do Cerrado.

\subsection{A RELAÇÃO ENTRE O URBANO E A PRODUÇÃO DO AGRONEGÓCIO}

Tendo o seu território inserido no meio técnico-científico-informacional (SANTOS, 2008a), Mato Grosso, por meio principalmente dos agentes hegemônicos, passa a organizar o seu espaço com vistas a atender as novas demandas e as novas conexões advindas do novo processo.

Uma das grandes transformações no território mato-grossense ocorre no meio urbano, que é chamado a colaborar com o novo meio agrícola mecanizado, por meio do controle gerencial de algumas ações dos processos produtivos que se tornam mais densos e complexos, e que demandam todo um aparato organizacional à montante e à jusante da produção.

Apesar de os mecanismos de controle de fato se estruturarem longe das áreas produtoras - inclusive das cidades que lhes dão suporte, porque são presididos pelos agentes hegemônicos de capital estrangeiro -, temos um processo de transformação das cidades, que se refuncionalizam ou são criadas no contexto das novas dinâmicas inerentes ao agronegócio.

Dessa condição ocorre uma intensificação das relações entre o urbano e a agricultura. Inclusive Diniz (2013, p. 26) ao propor ajustes nas políticas públicas para a mitigação das assimetrias entre as regiões brasileiras, reforça o papel central do urbano ao argumentar que “[...] o processo de urbanização, pela sua força, passa a ter um papel central no ordenamento do território e como base de consumo e de suporte produtivo ao seu entorno".

Nesse sentido, Lencioni (1985, p. 43) ao analisar as relações entre a urbanização e a agricultura faz a seguinte consideração: 
A importância de se discutir essa relação decorre do fato de que a reprodução do capital no campo não pode prescindir da existência da cidade. Neste sentido, entendemos a cidade como materialização das condições gerais de produção e consumo historicamente determinadas.

Como parâmetro, a partir da década de 1970, são criados 107 dos atuais 141 municípios mato-grossenses (MATO GROSSO, 2013b). A dinâmica de criação de municípios está fundada na necessidade de atender as necessidades da reprodução social de uma forma geral, mas também para permitir um controle maior por parte das elites, cujos interesses econômicos se somam aos interesses políticos, em consonância com os novos usos do território.

A modernização do campo cria um tipo específico de município, ou ainda, uma família de municípios que possuem, apesar das singularidades, funcionamento adequado ao novo modelo produtivo presente em vastas áreas do Cerrado mato-grossense. Silva (2009, p. 88) assim as define:

\begin{abstract}
A família de municípios do agronegócio caracteriza por ser um conjunto de municípios novos ou municípios antigos com novas infra-estruturas, que surgem como resposta às solicitações do mercado para uma produção moderna, tendo em comum uma única dinâmica econômica a lhes imprimir seu movimento.
\end{abstract}

Apesar de não possuírem um maior controle do processo produtivo, as suas cidadessedes atendem a uma funcionalidade do mercado e das elites sociais e políticas, já que, conforme aponta Seabra (2009, p. 416), "Materialmente o espaço urbano entra no circuito de produção e consumo da sociedade". O controle do processo produtivo pode levar a um controle da materialidade urbana, assim como da materialidade rural. As necessidades de um novo fazer, moderno e dotado de relações extrovertidas, exige um novo urbano, também consoante com a modernidade do setor produtivo.

As repercussões das novas funções que esses espaços urbanos passam a cumprir ultrapassam os limites nacionais e, guardada as devidas proporções, são organizadas para que essas cidades funcionem como cidades corporativas. Para tal, necessitam ser devidamente equipadas, criando um quadro de seletividade espacial. 
Santos (2008b, p. 109), ao abordar a questão da urbanização e das cidades corporativas, assevera que:

No Brasil moderno pós-1964, conjugam-se, como a mão e a luva, as exigências de inserção em nova ordem econômica mundial que se desenha e as necessidades internas de um Estado autoritário. A integração dos transportes e das comunicações (rapidamente modernizados) necessária à visão panóptica do território, é, igualmente, condição material para a difusão, além das regiões centrais mais desenvolvidas, de atividades industriais e agrícolas altamente capitalistas.

Um exercício comparativo entre o Mapa 15, e a Figura 14, nos dá uma ideia de como o processo de reestruturação redundou na gênese de diversas cidades, principalmente nas áreas setentrionais onde a expansão do agronegócio demandava bases urbanas de apoio à especialização produtiva em curso.

O Mapa 15, traz uma periodização dos desmembramentos que redundaram na gênese dos municípios em Mato Grosso - considerando a data em que foram criados formalmente por meio de documentos oficiais -, juntamente com a rede de transporte rodoviário instalada, que proporciona a articulação intrarregional e inter-regional necessária à integração dos mercados.

Já o cartograma apresentado na Figura 14, demonstra a evolução da produção de soja dos municípios nos últimos onze anos, cuja consolidação é fruto dos processos de reestruturação efetivados. No conjunto, é possível falar de uma convergência de dinâmicas, pois as principais áreas produtoras estão contidas nas áreas emancipadas a partir de 1970.

Mesmo tendo claro que toda generalização é passível de falha, em virtude das especificidades dos diversos processos que possibilitam a criação de um município e de sua cidade-sede, entendemos que a dinâmica oriunda da maior integração de Mato Grosso após 1970, favoreceu e fomentou a municipalização. 
Mapa 15 - Evolução do processo de municipalização de Mato Grosso

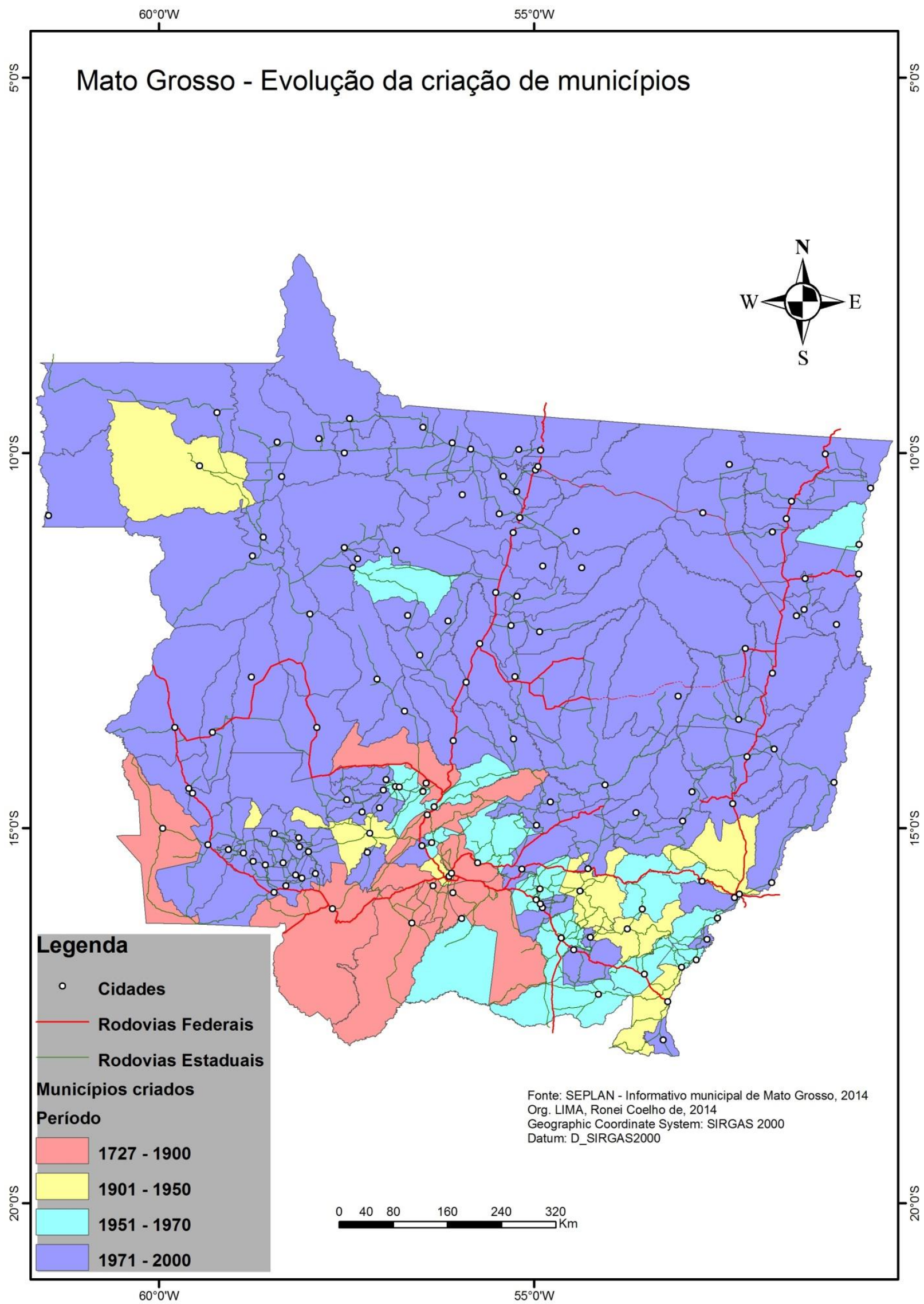

Fonte: SEPLAN-MT - Informativo municipal de Mato Grosso, 2013b. 
Figura 14 - Cartograma da evolução da produção de soja em Mato Grosso de 2004 a 2014
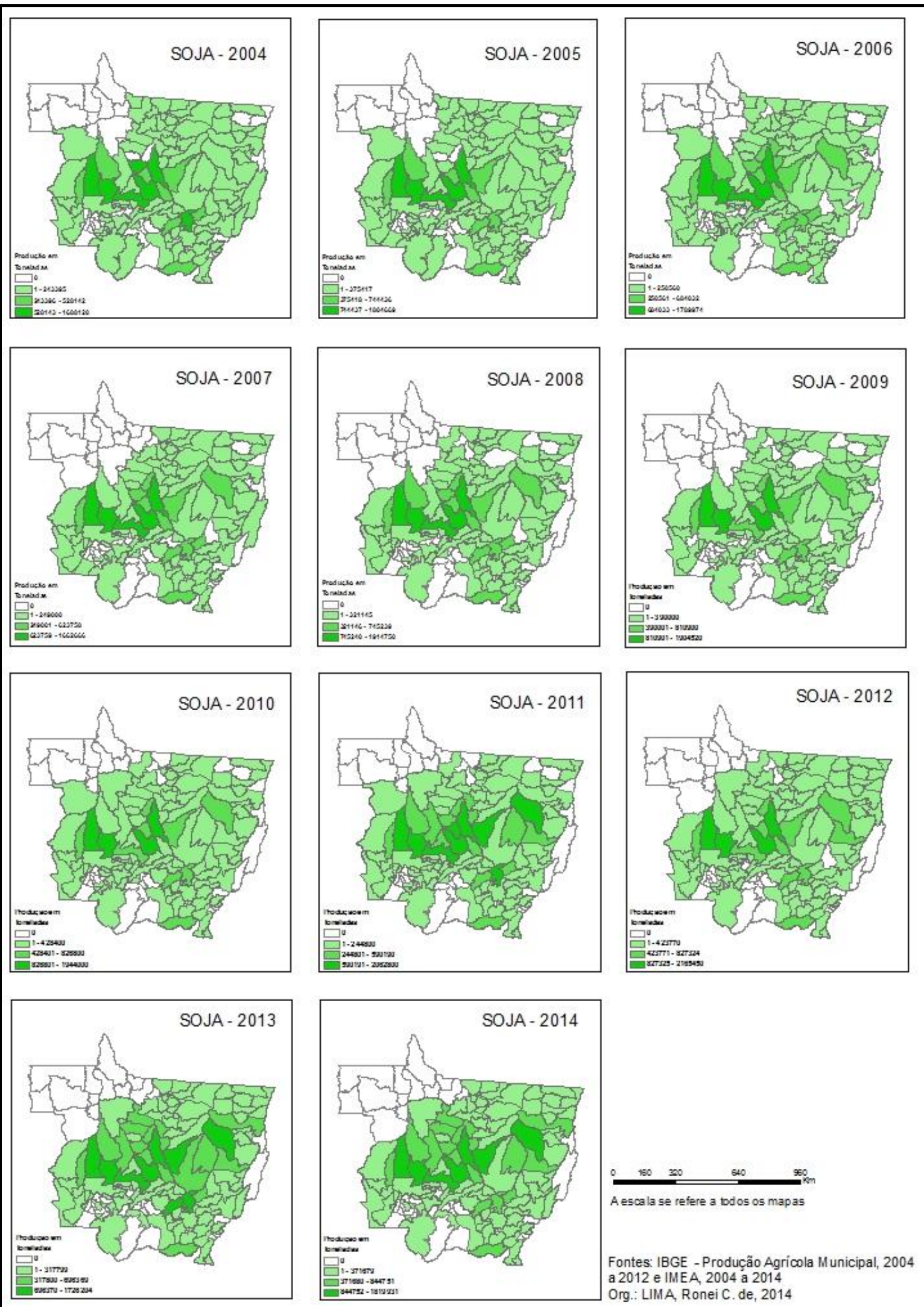

Fontes: IBGE - Produção Agrícola Municipal, 2014 e IMEA, 2014 Org. LIMA, R. C. (2014) 
Consideramos que a produção tecnificada, sobretudo a produção de grãos, contou com as condições políticas favoráveis - inclusive com a formação de uma elite do agronegócio, conforme aponta Silva (2009) - para disseminar-se pelas áreas de Cerrado e promover as transformações necessárias no território para a reprodução do modelo produtivo, possibilitando uma integração da porção Norte do estado aos novos circuitos econômicos já existentes no Centro-Sul do Brasil.

Essa integração está em conformidade com os ajustes espaciais demandados pelo capitalismo em seu processo de reprodução ampliada, pois como nos lembra Harvey (2006, p. 118) "O desenvolvimento desimpedido do capitalismo em novas regiões é uma necessidade absoluta do capitalismo", pois nos lugares novos é que estão oportunidades de crescimento em decorrência da criação de novos mercados e de novas possibilidades de investimentos mais rentáveis.

Assim, a grande demanda por infraestrutura, por implementos e insumos que emerge nas novas fronteiras agrícolas, caso das novas áreas produtoras de Mato Grosso, favoreciam os mercados centrais na medida em que eram criados novos mercados consumidores. $\mathrm{O}$ pacote tecnológico já existente e disseminado em países da Europa e nos Estados Unidos passa a ser aplicado aos países periféricos, caso do Brasil.

No conjunto apresentado no Mapa 15, dividido em quatro períodos, temos processos diferentes de ocupação e interesses sobre o território ocupado, cada um representando as dinâmicas próprias de suas respectivas produções sociais historicamente constituídas:

- O primeiro período, com a fundação de Cuiabá em 1727, indo até o início do século $\mathrm{XX}$, em que a fundação de vilas e cidades estava vinculada às atividades garimpeiras e seus núcleos de abastecimento - Cuiabá (1727), Diamantino (1820), Poconé (1831), Rosário Oeste (1861), Nossa Senhora do Livramento (1883) e Santo Antônio do Leverger (1890); e ocupações de caráter geopolítico, em virtude da necessidade de ocupação de áreas fronteiriças - Vila Bela da Santíssima Trindade (1752) e Cáceres (1850). Os rios, Paraguai e Cuiabá favoreciam os fluxos em um período de poucos e precários caminhos por terra. Daí a concentração espacial das emancipações deste período.

- Uma segunda etapa inicia-se no século XX, com a atividade garimpeira ainda dinamizando áreas que se tornariam núcleos urbanos em seguida, caso de Alto 
Araguaia (1938), Poxoréu (1938), Guiratinga (1943). Além desses são emancipadas Barra do Garças (1948) e Várzea Grande (1948), sendo a primeira importante polo do Leste mato-grossense e a segunda uma das principais áreas industriais de Mato Grosso. Os novos municípios estão localizados na porção Centro-Sul do estado, excetuando-se Aripuanã (1943), localizado na porção Noroeste.

- De 1951 a 1970 as emancipações se dão por motivos variados, pois foram criados 19 municípios, com destaque para Rondonópolis (1953), que se tornaria a segunda economia do estado de Mato Grosso e a terceira em população. É nas imediações de Rondonópolis, e capitaneada por esta, que a modernização da agricultura chega em Mato Grosso (aqui estamos considerando o estado já dividido), onde foram iniciadas as primeiras plantações de soja no final dos anos de 1970, conforme aponta Silva (2003, p. 70). A concentração no Centro-Sul do estado permanece, pois aí se encontravam as melhores (mesmo que precárias) condições de infraestruturas de transportes, de energia e de comunicações. Fogem da concentração espacial das emancipações desse período os municípios de Luciara (1963) na porção Nordeste e Porto dos Gaúchos (1963) no Médio-Norte de Mato Grosso.

- O quarto período, representado pelas emancipações que ocorreram a partir de 1971 em diante (tendo o ano de 2000 como limite em virtude da não regulamentação da criação de novos municípios), é o mais importante em quantidade (107 municípios emancipados) e em qualidade (tendo em vista que resultam do período de reestruturação do território face às necessidades de integração aos mercados nacional e internacional e a consolidação da inserção de amplas áreas do estado ao meio técnicocientífico-informacional e todos os processos inerentes à nova condição). Assim, foram emancipados neste período todos os municípios da área concentrada da soja (BERNARDES, 2010), quais sejam: Sorriso (1986), Nova Mutum (1988), Nova Ubiratã (1995), Lucas do Rio Verde (1988), Tapurah (1988) e outros municípios produtores do Médio-Norte, assim como Sinop (1979); além dos principais produtores da porção Oeste do estado, Sapezal (1994), Campo Novo do Parecis (1988) e Campos de Júlio (1994); da porção Leste, Querência (1991) e Canarana (1979); da porção Sudeste, Primavera do Leste (1986) e Campo Verde (1988). As emancipações resultaram das políticas de colonizações públicas e privadas que propiciaram a ocupação das áreas até então pouco integradas, permitindo que a população, entendida 
enquanto recurso - de acordo com o que coloca Raffestin (1993) -, fosse instalada se tornando a mão de obra necessária à nova dinâmica produtiva. Esse recurso passa a ser mais utilizado nas cidades, pois no campo a mecanização expulsa grande parte da massa de trabalhadores, que passam a ocupar as periferias das cidades.

O Mapa 15, também destaca a localização das sedes dos municípios, onde vemos a estreita relação das cidades mato-grossenses com a rede de transportes instalada. É o modal rodoviário, destacado no mapa pelas rodovias federais e estaduais pavimentadas que permitem a articulação de mercadorias e pessoas entre as cidades. Mas nem todas possuem a infraestrutura de transportes adequada, e podemos observar cidades cujas ligações ainda hoje são feitas por meio de rodovias sem pavimento e em condições precárias, reduzindo a fluidez material (pessoas e mercadorias) e dificultando a expansão de fluxos diversos.

Esses fluxos fazem parte das interações espaciais efetivadas pelas cidades matogrossenses, sendo essas interações entendidas conforme aponta Corrêa (1997, p. 279):

As interações espaciais constituem um amplo e complexo conjunto de deslocamento de pessoas, mercadorias, capital e informação sobre o espaço geográfico. Podem apresentar maior ou menor intensidade, variar segundo a frequência de ocorrência e, conforme a distância e direção, caracterizar-se por diversos propósitos e se realizar através de diversos meios e velocidades.

A diferente distribuição da infraestrutura de transportes, energia e comunicações favorece a maior densidade das interações espaciais de algumas cidades em relação às outras.

Essa diferenciação se dá porque a estruturação do território é socialmente construída, e no jogo de forças entre os lugares alguns levam vantagens por diversos motivos, como os naturais (adequação à produção mecanizada - caso das áreas dos chapadões em Mato Grosso), locacionais (cidades posicionadas próximas de rodovias, ferrovias e outras redes técnicas) e políticos (maior representatividade nas diversas escalas do poder público), sendo que as interações resultam do conjunto de elementos contidos no processo de reprodução e transformações sociais. 
Neste sentido e fazendo a relação direta das interações espaciais sob a égide do capitalismo, Corrêa (op. cit., p. 280) faz o seguinte esclarecimento:

No que se refere à existência e reprodução social, as interações espaciais refletem as diferenças de lugares face às necessidades historicamente definidas. No que concerne às transformações, as interações espaciais caracterizam-se, preponderantemente, por uma assimetria, isto é, por relações que tendem a favorecer um lugar em detrimento de outro, ampliando as diferenças já existentes, isto é, transformando os lugares.

As desigualdades espaciais historicamente definidas fazem parte do movimento capitalista sobre o território. A criação de municípios facilita a evolução desse movimento na medida em que favorece a instalação das condições de reprodução do capital, caso da necessidade da força de trabalho para a realização capitalista da produção, pois como vimos, é nas cidades que encontramos os suportes da produção agrícola, principal motor da economia de Mato Grosso.

De acordo com Elias (2011, p. 160):

[...] é possível identificar no Brasil agrícola moderno, seja nos espaços de reserva, seja nas áreas já há mais tempo inseridas na produção moderna, vários municípios cuja urbanização se deve diretamente à consecução e à expansão do agronegócio globalizado e cuja função principal claramente se associa às demandas produtivas dos setores relacionados à organização das redes agroindustriais.

A autora entende que houve um crescimento de áreas urbanizadas em consonância com o processo de intensificação do capitalismo no campo e a consecutiva difusão do agronegócio, pois o novo modelo produtivo da agropecuária demanda ações de gestão encontradas nos espaços urbanos, sendo que essa condição "[...] colabora para o Brasil chegar ao século XXI com uma generalização do fenômeno da urbanização da sociedade e do território" (ELIAS, op. cit., p 160).

Tomando como elemento de análise os vinte maiores produtores do agronegócio matogrossense (considerando a produção de soja), apresentados no Quadro 13, evidencia-se que a 
dinâmica de municipalização e urbanização é um fenômeno consoante com a nova lógica produtiva, pois caracteriza um movimento de maior controle territorial para os agentes interessados (nova elite) e uma demanda por serviços urbanos surgida no contexto da produção modernizada.

\section{Quadro 13 - Dados gerais dos 20 maiores produtores de soja de Mato Grosso em 2014}

\begin{tabular}{|c|c|c|c|c|}
\hline Município & $\begin{array}{c}\text { Data de } \\
\text { emancipação }\end{array}$ & $\begin{array}{c}\text { Produção de } \\
\text { soja em } 2014 \\
\text { em } \\
\text { toneladas }\end{array}$ & $\begin{array}{c}\text { População } \\
\text { Estimada } \\
\text { em } 2014\end{array}$ & $\begin{array}{c}\text { Taxa de } \\
\text { urbanização } \\
\text { em } 2010 \\
\%\end{array}$ \\
\hline Sorriso & 1986 & 1.819 .931 & 77.735 & 87,7 \\
\hline Sapezal & 1994 & 1.253 .559 & 21.811 & 83,6 \\
\hline Nova Mutum & 1988 & 1.204 .215 & 38.206 & 81,7 \\
\hline Campo Novo do Parecis & 1988 & 1.171 .986 & 31.171 & 92,8 \\
\hline Diamantino & 1820 & 1.142 .600 & 20.945 & 78,1 \\
\hline Nova Ubiratã & 1995 & 1.103 .703 & 10.508 & 64,3 \\
\hline Querência & 1991 & 1.056 .425 & 15.121 & 45,8 \\
\hline Primavera do Leste & 1986 & 844.751 & 56.450 & 94,6 \\
\hline Campo Verde & 1988 & 838.960 & 36.800 & 80,6 \\
\hline Lucas do Rio Verde & 1988 & 734.180 & 55.094 & 93,2 \\
\hline Ipiranga do Norte & 2000 & 659.411 & 6.347 & 67,8 \\
\hline Campos de Júlio & 1994 & 652.532 & 5.969 & 77,9 \\
\hline Brasnorte & 1986 & 645.548 & 17.361 & 65,4 \\
\hline Canarana & 1979 & 614.985 & 19.948 & 78,9 \\
\hline Itiquira & 1953 & 586.303 & 12.293 & 38,7 \\
\hline Tapurah & 1988 & 534.849 & 11.950 & 62,8 \\
\hline Santa Rita do Trivelato & 1999 & 482.228 & 2.935 & 54,9 \\
\hline Sinop & 1979 & 482.055 & 126.817 & 82,9 \\
\hline Tabaporã & 1991 & 479.088 & 9.582 & 52,8 \\
\hline Santo Antônio do Leste & 1998 & 461.695 & 4.435 & 38,8 \\
\hline
\end{tabular}

Fontes: IBGE - Cidades, 2015; IMEA, 2014, SEPLAN - Informativo Municipal de Mato Grosso, 2013

É possível observar alguns elementos importantes para a análise, primeiro que há um padrão de alta urbanização no grupo, principalmente nos municípios mais populosos cujas condições respondem estruturalmente pela oferta de bens e serviços demandados pelo agronegócio, casos de Sinop, Sorriso e Primavera dos Leste. Algumas baixas taxas de urbanização estão relacionadas à existência de assentamentos rurais e pequenas propriedades que resistem em meio às grandes propriedades rurais que são características desses municípios.

Nesse sentido, Nova Ubiratã com 64\% de taxa de urbanização (TU), localizada no eixo de produção do Médio-Norte possui quatro assentamentos rurais, Querência (45,8\% TU), que é o maior produtor de soja da nova área de expansão, representado pelo Nordeste matogrossense, no eixo da BR-158, possui cinco assentamentos rurais, o que resulta na menor taxa 
de urbanização. Da mesma forma, no município de Itiquira (38,7\% TU), localizado na porção Sul, existem cinco assentamentos rurais e diversas pequenas propriedades rurais cujas populações se somam aos funcionários de algumas grandes fazendas que residem nestas em agrovilas. Santo Antônio do Leste (38,8\% TU), situado no Leste mato-grossense, possui um assentamento rural e parte das propriedades rurais do município possui sedes abrigando os proprietários e funcionários, e como a população total é reduzida, esses habitantes rurais consolidam, por enquanto, essa condição atípica de baixa urbanização.

Quanto à criação, duas exceções são verificadas, pois os municípios de Diamantino e Itiquira foram fundados antes da década de 1970. Diamantino (1820), município antigo e de origem garimpeira, está localizado entre a área de produção do Oeste do estado com o MédioNorte, principal área de produção do agronegócio. Itiquira (1953), também tem no garimpo sua gênese, além da pecuária. Atualmente é o maior produtor de soja do Sul de Mato Grosso. Os dois municípios possuem as condições naturais adequadas para a produção, apesar das suas respectivas sedes não apresentarem um dinamismo próximo do que ocorre na área concentrada da soja no Médio-Norte.

Em um contexto mais amplo, os jovens municípios do grupo apresentam expressivas taxas de urbanização, característica geral do estado de Mato Grosso, que é um reflexo da concentração fundiária do estado, já discutida anteriormente, e pelo modelo baseado na mecanização agrícola, cuja base técnica impede uma maior absorção de mão de obra no campo, fazendo com que as cidades sejam os centros de apoio da produção, inclusive disponibilizando a mão de obra. Nesse sentido, Lencioni (1985, p. 48) chama a atenção para o fato de que "A elevação da composição orgânica do capital no campo concorreu para a diminuição da força de trabalho empregada na agricultura e para a proletarização do trabalhador rural $[\ldots] "$.

Ao discutir o processo da urbanização brasileira na sua fase mais recente, Santos (2008b, p. 11) faz a seguinte consideração:

O campo brasileiro moderno repele os pobres, e os trabalhadores da agricultura capitalizada vivem cada vez mais os espaços urbanos. A indústria se desenvolve com a criação de pequeno número de empregos, e o terciário associa formas modernas a formas primitivas que remuneram mal e não garantem a ocupação. [...] A cidade, onde tantas necessidades emergentes não podem ter resposta, está desse modo fadada a ser tanto o teatro de 
conflitos crescentes como o lugar geográfico e político da possibilidade de soluções.

A dinâmica da urbanização recente de Mato Grosso não foge a este processo, pois a criação de cidades relaciona-se ao novo período em que a modernização do campo e a integração produtiva com os mercados impõem novas condições ao território e às cidades, lugares escolhidos para gerir, parcialmente, a produção do campo, num processo de criação ou refuncionalização, de modo a atender a lógica corporativa.

Para Santos (2012), ao ser beneficiada com os progressos científicos e tecnológicos, a agricultura passa a produzir mais em áreas cada vez menores, utilizando-se menos de mão de obra na produção, e com isso:

A urbanização ganha, assim, novo impulso, e o espaço do homem, tanto nas cidades como no campo, vai se tornando um espaço cada vez mais instrumentalizado, culturizado, tecnificado e cada vez mais trabalhado segundo os ditames da ciência. (SANTOS, op. cit., p. 47).

Dessa forma, completa o autor, o campo passa a apresentar características da cidade industrial, como na questão do capital constante, hoje presente nas áreas agrícolas modernizadas por meio dos diversos implementos e insumos necessários à produção. A circulação deste capital, por sua vez, ocorre mediante a existência de redes rodoviárias e ferroviárias, que favorecem a redução de custos e que permitem o pleno atendimento das demandas urbanas existentes, principalmente nas cidades.

Essa condição de permitir a fluidez é um atributo imprescindível para a realização do processo produtivo e para a reprodução da vida no campo, mas principalmente nas cidades. Assim, passa a existir patamares diferenciados dos lugares, visto que a existência de sistemas de engenharia voltados às articulações dos diversos fluxos não ocorre de forma homogênea no espaço.

Resulta desse processo que grande parte dos lugares criados não podem atender as novas demandas, e também que a refuncionalização não garante àqueles lugares mais antigos estarem aptos para integrar os novos circuitos produtivos e, marginalmente, os círculos de 
cooperação do capital. Ocorre, por parte dos agentes hegemônicos, a seleção dos lugares cujos investimentos (privados e/ou públicos) possam ter retorno mais efetivo.

A escolha se dá, a princípio, pelas vantagens oferecidas, como a existência de infraestruturas demandadas pelo meio técnico-científico-informacional, como sistemas de transportes, energia e comunicações, mão de obra qualificada, serviços mais elaborados, pesquisas (existência de laboratórios, universidades, centros de pesquisas) e em alguns casos proximidade com as áreas de produção.

Nesse contexto, destacaremos as principais cidades que dão suporte para o agronegócio mato-grossense. Não deve restar dúvida, no entanto, de que se trata de um suporte cuja gestão está diretamente vinculada a interesses distantes, mas sempre associados com as elites locais, por essas serem parceiras importantes, já que dominam setores estratégicos como o político e o imobiliário, e são relevantes nas relações com a mão de obra necessária para o funcionamento do sistema produtivo em si.

\subsection{LUGARES ESCOLHIDOS: CIDADES REFUNCIONALIZADAS E CIDADES CRIADAS}

Passaremos à discussão das condições que levaram certas áreas a despertarem o interesse de agentes hegemônicos para a consecução de estratégias de reprodução do capital na fronteira agrícola de Mato Grosso. A maior articulação dessa porção do território com a economia nacional e internacional permitiu uma integração ao modelo já consolidado nas regiões Sul e Sudeste. A especialização produtiva que foi sendo construída sistematicamente, em decorrência da reestruturação territorial condizente com as demandas globalizadas, promoveu alguns lugares novos (criados no processo, como os novos municípios e as cidades) ou refuncionalizados, para gerirem parcialmente os processos produtivos do meio rural.

Em relação aos lugares e sua condição no bojo do processo de globalização da sociedade e da economia, cujos desdobramentos promove, entre outros, a mundialização do espaço geográfico, Santos (2012, p. 32) aponta: 
Quando todos os lugares foram atingidos, de maneira direta ou indireta, pelas necessidades do processo produtivo, criam-se, paralelamente, seletividades e hierarquias de utilização, com a concorrência ativa ou passiva entre os diversos agentes. Donde uma reorganização das funções entre as diferentes frações do território. Cada ponto do espaço torna-se, então, importante, efetiva ou potencialmente. Sua importância decorre de suas próprias virtualidades, naturais ou sociais, preexistentes ou adquiridas segundo intervenções seletivas.

Assim, os lugares em Mato Grosso, como em qualquer lugar que o interesse capitalista esteja envolvido, passam a ser selecionados para atender a dinâmica do modelo produtivo moderno de acordo com as potencialidades individuais. As intenções dos agentes hegemônicos repercutem no território de maneiras diversas, mas convergentes. Pois, enquanto o Estado promove a criação das infraestruturas para dotar o território das condições adequadas ao seu funcionamento corporativo, caso da instalação de sistemas de engenharia de transportes, as grandes corporações se enraízam de forma definitiva ou transitória, aproveitando o potencial criado para desenvolver suas atividades produtivas.

No entanto, os limites apresentados no processo de reestruturação do território por parte do Estado e a resistência dos agentes privados em inverter capital, na forma de capital fixo, faz com que o território apresente apenas condições parciais de atendimento aos interesses capitalistas. Alguns lugares que se tornam receptores de investimentos sobressaemse no conjunto de lugares, sendo escolhidos e passando a integrar mais plenamente o circuito produtivo do agronegócio, no caso mato-grossense.

Nesse sentido, Arruda (2007, p. 114) faz uma colocação importante:

Todas as estratégias espaciais das grandes corporações do agronegócio que impõem a logística para a acumulação do capital, vão se configurar no território mato-grossense, na constituição de regiões e centros dinâmicos do agronegócio.

Para a autora, municípios como Rondonópolis, Sinop. Sorriso, Lucas do Rio Verde, Nova Mutum, Primavera do Leste, Campo Verde, Campo Novo do Parecis e Campos de Júlio polarizam grandes áreas produtoras e dão suporte às mesmas. Esses lugares, exceto Rondonópolis, fazem parte do grupo de municípios criados pós-1970, período em que a 
modernização produtiva se estabelece em Mato Grosso. É a demanda criada pela produção que fará a pressão sobre a infraestrutura existente, exigindo investimentos que se darão em ritmo diferente do crescimento do processo produtivo, como já salientamos anteriormente.

A espacialização das grandes corporações do agronegócio - considerando as plantas industriais cuja produção agrega valor dentro do estado -, nos dá uma ideia da seletividade dos lugares, pois a escolha racional das grandes empresas prevê retorno econômico certo dos investimentos, daí a importância das estratégias espaciais, pois uma série de variáveis é analisada para a inversão de capital.

Uma das variáveis mais importantes, se considerarmos a necessidade nodal de articulação que os fluxos globalizados exigem, é a condição da logística de transportes, o que nos obriga a indicar os lugares cuja estruturação desse setor tenha alcançado os melhores níveis, partindo de uma comparação interna destes no conjunto mato-grossense.

Assim, se consideramos por modal de transportes, o rodoviário qualifica as cidades ao longo das principais rodovias federais, mas nem todas, pois algumas são apenas atravessadas, criando o que Santos (2012, p. 61) chama de "curto-circuito da cidade próxima" ao tratar da explosão do engessamento característico da antiga noção de rede urbana, dessa forma, cidades como Rondonópolis, Sinop, Sorriso e Cuiabá, cujos nexos externos são mais acentuados em virtude das relações com o agronegócio, têm outro nível de articulação se comparadas às cidades de São Pedro da Cipa, Jangada, General Carneiro e grande parte das cidades matogrossenses.

Quanto ao modal ferroviário, a sua concentração no Sudeste do estado contempla quatro cidades diretamente (Alto Taquari, Alto Araguaia, Itiquira e Rondonópolis), porém com níveis diferenciados de articulação, com destaque para Rondonópolis. Já o modal hidroviário ainda se mostra em estado embrionário, com vistas à realização futura. Caso ocorra, as cidades do Nordeste mato-grossense, do Médio-Norte e Norte do estado, bem como a área polarizada por Cáceres, poderão repercutir territorialmente as vantagens locacionais junto às hidrovias projetadas.

As cidades criadas no contexto da modernização do campo após 1970, e cujo vinculo com o agronegócio tem sido aprofundado desde então, já são organizadas internamente para atender as novas funções demandadas pela nova racionalidade. Do conjunto podemos destacar aquelas com maior participação como suporte para o setor de serviços, como Sinop; setor da 
produção, como Sorriso, Sapezal, Nova Mutum, Campo Novo do Parecis e Querência; e setor da agroindústria, Lucas do Rio Verde e Primavera do Leste.

Apesar das diferenças quanto à formação interna de cada município e cidade, resultado das específicas construções sociais, as mesmas apresentam certa convergência no que tange às condições de suporte ao agronegócio, nos diversos setores necessários à plena realização do seu processo produtivo, e no cômputo das especializações produtivas já estabelecidas.

Podemos tratar como cidades refuncionalizadas aquelas que emancipadas antes de 1970, foram sendo adaptadas à nova dinâmica por meio da implantação de infraestruturas que as tornaram coerentes com a nova condição produtiva, bem como com ações voltadas à pesquisa e modernização do setor de serviços também concernentes com a nova realidade. Pois, como assinala Elias (2011, p. 159). "“...] os espaços urbanos próximos às áreas de difusão do agronegócio passam a ter novas funções inerentes às demandas desse”. Para a autora, ocorre uma expansão do consumo produtivo agrícola, em associação direta com as novas demandas do setor produtivo, levando a um crescimento da economia urbana, tendo em vista a relação intrínseca entre os circuitos espaciais da produção e os círculos de cooperação com o espaço urbano.

Nesse contexto, temos Rondonópolis - porta de entrada do agronegócio em Mato Grosso -, cuja estrutura interna foi sendo moldada de acordo com o movimento de expansão do novo modelo produtivo, mas em consórcio com a produção tradicional, caso da pecuária. O processo de industrialização do município, que é um grande polo industrial de Mato Grosso, revela a convivência das novas e antigas formas de produção, pois se de um lado temos as processadoras de grãos (Bunge, ADM, Noble) e de algodão (Têxtil Bezerra de Menezes - TBM), de fertilizantes (Yara, Heringer, Mosaic, Cocal, Fertipar e outras), voltados à moderna agricultura tecnificada, de outro temos os frigoríficos (Alibem-Agra, Superfrigo, Mataboi), a produção de rações animais (Novanis, Nutripura, Suprenorte e outras) que se integram à pecuária, tanto a tradicional (extensiva) quanto à moderna (confinamento).

Mas, enquanto os setores voltados à pecuária, nos casos apresentados, estão vinculados aos capitais nacionais, aqueles da agricultura moderna compõem as grandes corporações do agronegócio mundial, representando significativamente a espacialidade do ciclo de reprodução do capital, conforme aponta Corrêa (1997, p. 285), pois o ciclo "Implica múltiplas localizações e suas necessárias articulações, em virtude dos processos produtivo e do consumo apresentarem ampla escala, envolvendo diferentes lugares". 
Para o autor, dessa forma observa-se o rompimento dos horizontes espaciais limitados outrora existentes, bem como a complexificação da reprodução do capital e da sua espacialidade no contexto do processo de concentração e centralização do capital. A instauração, em âmbito mundial, das corporações multifuncionais e multilocalizadas acentua essa complexidade.

Esse processo impacta diretamente a dinâmica das cidades escolhidas para receber investimentos dessas corporações, logo, concordamos com Penna (2013, p. 212) quando a autora sustenta que:

A partir das grandes empresas mundiais e dos capitais e interesses a elas associados, e do novo padrão de desenvolvimento, são favorecidos os espaços e cidades que acumularam certas vantagens e que podem atender melhor os requisitos da denominada acumulação flexível.

É a atuação desse tipo de agente hegemônico que estamos discutindo, pois os seus interesses sobre o território compõe um projeto maior, com rebatimentos mundiais. Contudo, é no local que de fato se efetiva a ação produtiva, e as condições para a sua realização é oferecida às empresas por meio da corporatização do território para responder aos novos mandos e às novas funções.

O processo de refuncionalização - entendido enquanto ação sobre o espaço - provoca uma produtividade espacial, apontada por Santos (2008a, p. 247), gerando diferenciação na capacidade de rentabilizar a produção, já que “[...] as ações hegemônicas se estabelecem e se realizam por intermédio de objetos hegemônicos, privilegiando certas áreas. Então, como num sistema de sistemas, o resto do espaço e o resto das ações são chamados a colaborar.”.

No contexto mato-grossense, a escolha de Rondonópolis não foi aleatória, mas sim intencional, pois a cidade possuía as melhores condições disponíveis (maior proximidade em relação aos principais centros econômicos do país e uma razoável infraestrutura já instalada sistema de transportes, energia e comunicações). Com isso passou a receber investimentos que permitiram a reprodução ampliada do capital das grandes corporações instaladas. Da mesma forma, mas em menor escala, outras cidades receberam investimentos produtivos em decorrência dos atributos apresentados no momento da escolha, caso de Primavera do Leste (Cargill), Nova Mutum (Bunge), Lucas do Rio Verde (BRF), Alto Araguaia (LDC). 
A questão da transitoriedade dos investimentos pode ser explicada pelo caso da cidade de Alto Araguaia, pois como vimos anteriormente, o município recebeu investimentos importantes com a instalação do terminal ferroviário da ALL, o que a dotou de vantagens comparativas, que foram aos poucos sendo dissipadas com a reorientação dos fluxos para o terminal ferroviário de Rondonópolis. Hoje, por conta dos interesses corporativos, principalmente da ALL, é mais rentável embarcar em Rondonópolis do que em Alto Araguaia.

Na guerra dos lugares (SANTOS, 2008a, p. 247), Rondonópolis apresenta vantagem atualmente em virtude das condições de ordem técnica, principalmente da localização (entroncamento rodoferroviário das BRs 163/364 com a AALMN e maior proximidade das áreas produtoras) e acessibilidade. Quanto às vantagens de ordem organizacional (leis, relações trabalhistas, impostos) não há diferenciação significativa, mas do contrário, em virtude da maior proximidade dos órgãos de controle, há um maior rigor nas fiscalizações das condições de trabalho daqueles envolvidos na logística de transportes.

No entanto, a vantagem atual também pode ser transitória, caso os eventos programados pelos agentes hegemônicos, pensados para o médio prazo, se concretize. Pois com a inversão logística para o Norte, talvez passe a ser Lucas do Rio Verde (com a construção da FICO, ou da ferrovia Lucas do Rio Verde-Miritituba), ou Sinop (com a finalização do asfaltamento da BR-163 no Pará e a sua duplicação no trecho mato-grossense até Sinop e a construção da hidrovia do Teles Pires) os lugares mais racionais para futuros investimentos corporativos.

A realidade atual ainda coloca Rondonópolis como área estratégica de investimentos corporativos em Mato Grosso, o que é refletido na participação do PIB industrial no total do PIB do município da ordem de 32\%, com uma produção industrial de R \$ 1.909.522.000,00 no ano de 2012, segundo aponta os dados do IBGE (2014b).

Os rebatimentos decorrentes da corporatização do território terminam por impactar profundamente as cidades mato-grossenses. Aquelas escolhidas apresentam vantagens nos diversos índices apurados, caso do PIB e PIB per capita, do Índice de Desenvolvimento Humano Municipal (IDHM), de crescimento populacional, de arrecadação por meio do Índice de Participação dos Municípios (IPM) e outros, cujos valores servem principalmente para os agentes hegemônicos tentarem ratificar, junto à opinião pública, as vantagens que o agronegócio traz para o estado de Mato Grosso e para os seus municípios. Mas os números 
não conseguem abarcar a complexidade e a realidade concreta do cotidiano e das relações sociais existentes nas cidades e no campo.

A seguir discutiremos alguns impactos no urbano mato-grossense, pois é esse urbano o responsável pelo suporte e a articulação das atividades do agronegócio em meio às contradições, problemas e vantagens relacionados com a racionalidade desse modelo produtivo, sendo que a complexidade desse processo é equivalente à profundidade da integração apresentada.

\subsection{IMPACTOS NO URBANO MATO-GROSSENSE}

Algumas cidades mato-grossenses ligadas ao agronegócio são conhecidas por um padrão no seu arranjo urbano, fruto de uma racionalidade derivada do próprio setor produtivo. Esse padrão, no entanto, reflete a busca por um maior controle do crescimento urbano, inclusive com a escolha, sempre que possível, daqueles que irão de fato morar no perímetro urbano. Os desenhos simétricos, racionais, as ruas largas, arborizadas, com um perímetro urbano muitas vezes contíguo com as áreas da produção agrícola é uma realidade de algumas cidades mais novas, criadas no movimento de expansão da agricultura moderna. A Figura 15, apresenta aspectos da paisagem de algumas cidades mato-grossenses que possuem essas características. 
Figura 15 - Vista aérea de cidades voltadas ao agronegócio

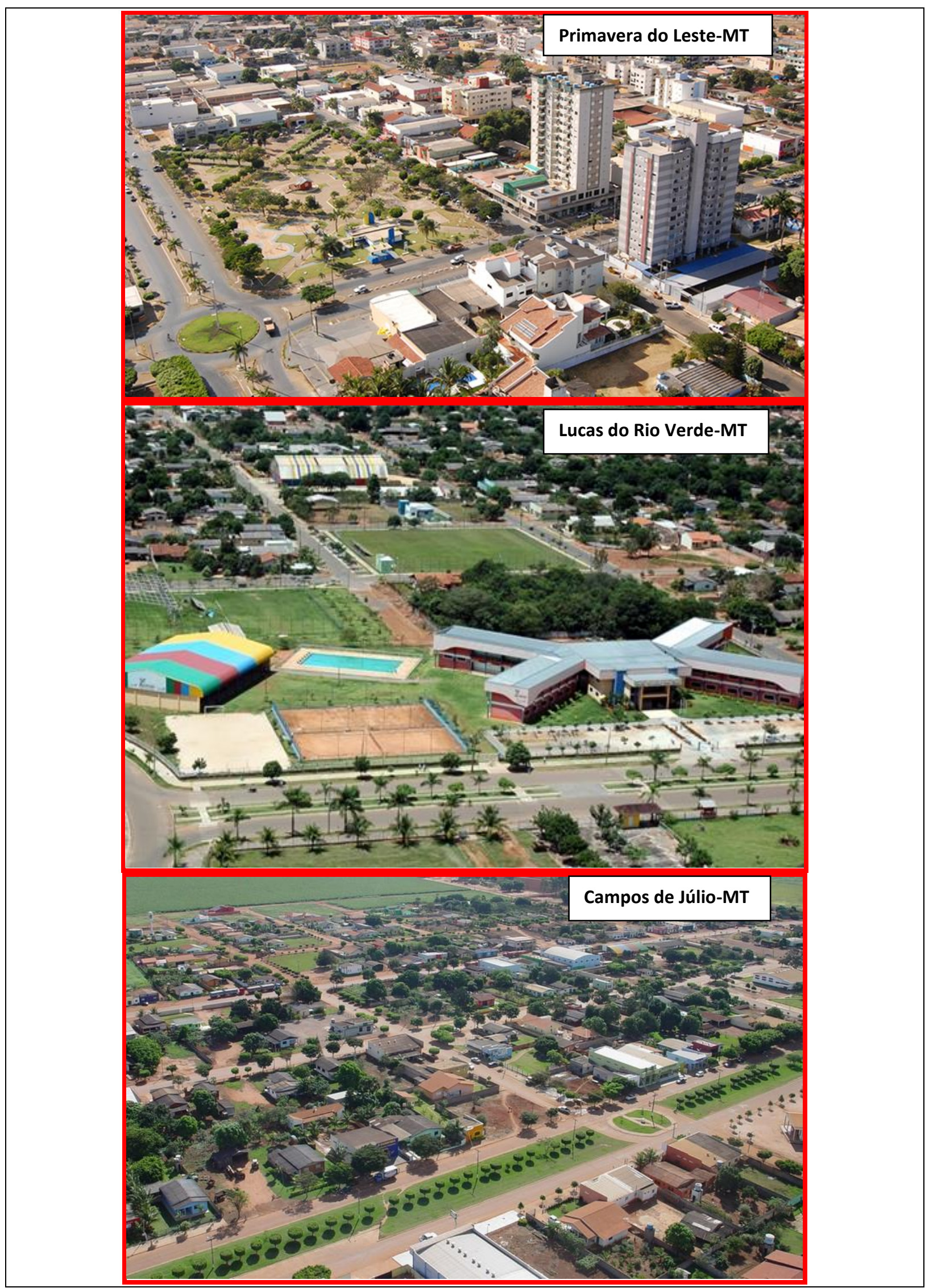

Fontes: Prefeituras Municipais de Primavera do Leste, Lucas do Rio Verde e Campos de Júlio 
A racionalidade do traçado e a harmonia do desenho urbano, principalmente no centro e nas áreas de entrada das cidades, mascaram em alguns casos as contradições internas, criadas no conjunto do jogo de forças sociais que alimentam a construção do espaço urbano. Considerando um contexto mais amplo, a existência de cidades cujo controle do fluxo migratório é menos efetivo, favorece a presença de pessoas menos abastadas que se fixam em moradias improvisadas na periferia das cidades e nas proximidades das vias de acesso.

Mas há cidades que buscam um maior controle, e o preço do solo urbano - muitas vezes controlado pelas colonizadoras privadas que fundaram as cidades -, inibem o assentamento de certas camadas sociais. Dessa forma, a especulação imobiliária e o controle da terra, tanto a rural como a urbana, criam um padrão espacial específico em algumas cidades mais vinculadas ao agronegócio, pois os custos de acesso ao mercado imobiliário são mais elevados se comparados ao conjunto do estado de Mato Grosso.

Assim, o controle do solo urbano parece ser bem intenso nas cidades criadas no movimento de expansão do agronegócio em Mato Grosso. Como exemplo, temos cidades como Sapezal, no Oeste do estado - cujo município atualmente é o segundo maior produtor de soja do estado -, que por meio da Cidezal Agrícola Ltda pertencente ao Grupo André Maggi procurou implantar um sistema de assentamento urbano com regras rígidas de ordenação e de qualidade das construções.

Segundo argumenta Silva (2003, p. 201) procurava-se evitar a proliferação de bolsões de pobreza, e a fundação da cidade não contava com a criação de espaços para os descapitalizados e desqualificados, que ficavam retidos nas triagens efetivadas pela Cidezal, no entanto, a contradição do processo é que,

[...] Há uma carência de mão-de-obra menos qualificada na cidade e no campo. Os mecanismos de controle da ocupação urbana não previam a presença de uma população pobre, mas como a reprodução do capital se faz pela presença de mão-de-obra barata e com baixo nível educacional, a política de loteamento já dispõe de uma área destinada à população de baixa renda.

O controle de aquisição do solo urbano, somado ao seu alto custo, impede o acesso de parte da população de muitas cidades à casa própria, fenômeno que pode ser constatado no Mapa 16, onde é possível observar uma concentração maior de imóveis alugados aos 
residentes urbanos nas cidades voltadas ao agronegócio, principalmente naquelas criadas no último quartel do século XX.

Ocorre que a valorização da terra agrícola no Cerrado, fenômeno que se intensifica nas áreas servidas pela engenharia de transportes, transborda ao urbano e, quanto mais recente é a criação da cidade, maior o controle do solo urbano. 
Mapa 16 - Taxa de domicílios alugados em Mato Grosso em 2010

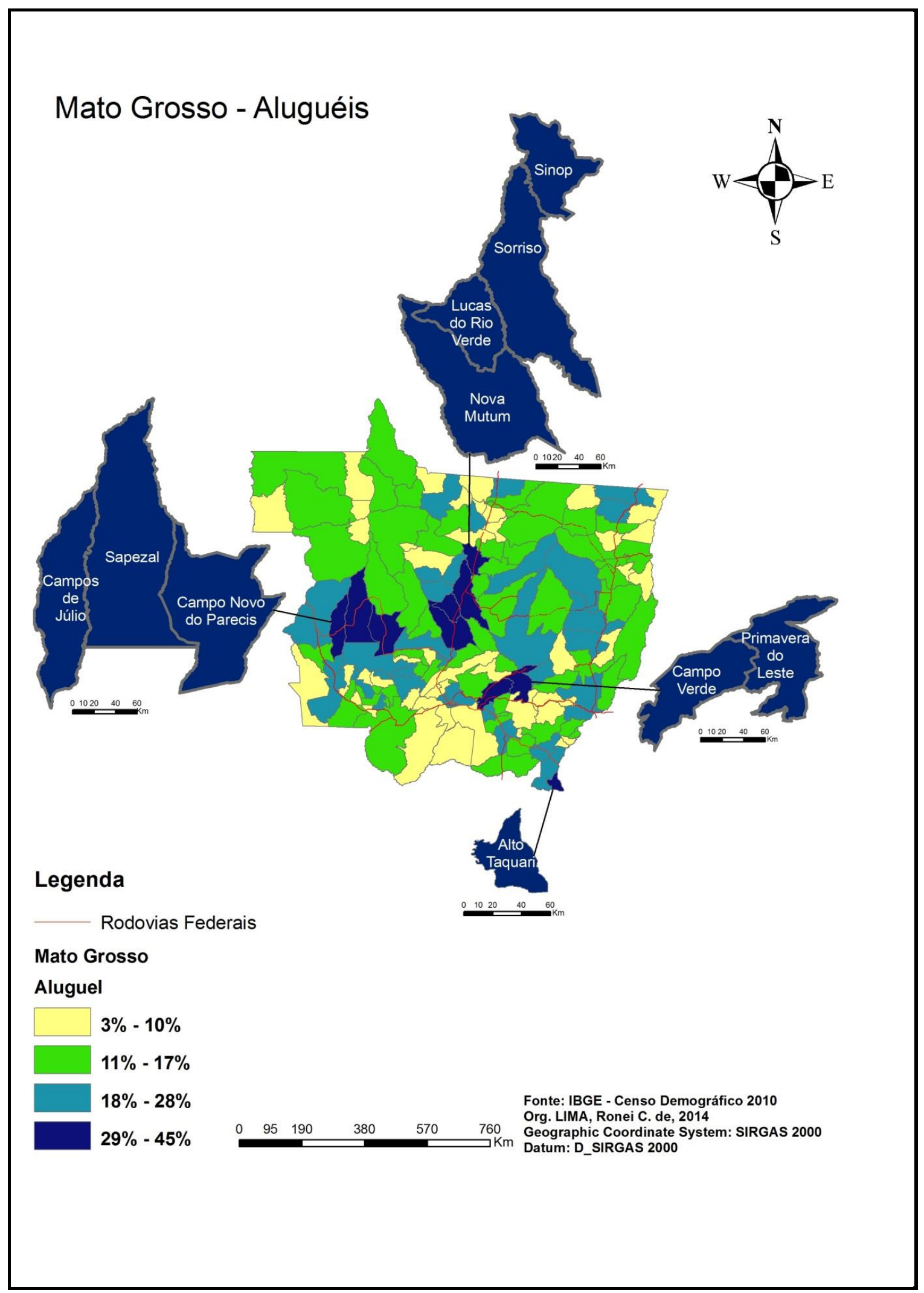

Fonte: IBGE - Censo Demográfico de 2010 
Este fato decorre, entre outros motivos, da grande quantidade de projetos de colonização públicos e privados que criaram diversas cidades em Mato Grosso, como é o caso daquelas localizadas no eixo da BR-163, como: Lucas do Rio Verde (colonização pública), Sorriso, Nova Mutum e Sinop (colonização privada).

Ao discutir a questão da implantação dos projetos de colonização Oliveira (2005, p. 73) entende que Estado e capital privado caminham juntos, ocorrendo nesse processo um corte monopolista, em que não há uma lógica do livre mercado, mais um processo de monopolização em que a terra, enquanto propriedade privada, é a mercadoria. Isto ocorre porque a economia brasileira "ingressou na era dos monopólios, internacionalizou-se, mundializou-se.".

Na Tabela 7, compilamos a condição dos domicílios das vinte cidades cujo acesso à moradia ocorre por meio do aluguel em elevadas taxas.

Tabela 7 - Condição do domicílio de municípios selecionados de Mato Grosso em 2010

\begin{tabular}{|c|c|c|c|c|c|c|c|}
\hline \multirow{2}{*}{ Município } & \multirow{2}{*}{$\begin{array}{c}\text { Total de } \\
\text { domicílios }\end{array}$} & \multicolumn{6}{|c|}{ Condição do domicílio } \\
\hline & & Próprio & $\%$ & Alugado & $\%$ & Outros & $\%$ \\
\hline Lucas do Rio Verde & 13.769 & 6.246 & 45 & 6.220 & 45 & 1.303 & 9 \\
\hline Nova Mutum & 9.429 & 3.877 & 41 & 4.005 & 42 & 1.547 & 16 \\
\hline Campo Novo do Parecis & 8.397 & 3.926 & 47 & 3.249 & 39 & 1.222 & 15 \\
\hline Primavera do Leste & 15.771 & 8.311 & 53 & 6.052 & 38 & 1.408 & 9 \\
\hline Sapezal & 5.390 & 2.281 & 42 & 2.027 & 38 & 1.082 & 20 \\
\hline Sorriso & 19.887 & 11.015 & 55 & 6.769 & 34 & 2.103 & 11 \\
\hline Alto Taquari & 2.393 & 1.357 & 57 & 752 & 31 & 284 & 12 \\
\hline Campos de Júlio & 1.504 & 705 & 47 & 470 & 31 & 329 & 22 \\
\hline Campo Verde & 9.432 & 5.229 & 55 & 2.815 & 30 & 1.388 & 15 \\
\hline Sinop & 34.020 & 21.077 & 62 & 10.050 & 30 & 2.893 & 9 \\
\hline Tangará da Serra & 25.605 & 15.923 & 62 & 7.242 & 28 & 2.440 & 10 \\
\hline Ipiranga do Norte & 1.559 & 803 & 52 & 371 & 24 & 385 & 25 \\
\hline Querência & 3.657 & 2.161 & 59 & 852 & 23 & 644 & 18 \\
\hline Água Boa & 6.422 & 4.117 & 64 & 1.476 & 23 & 829 & 13 \\
\hline Jaciara & 8.154 & 5.257 & 64 & 1.872 & 23 & 1.025 & 13 \\
\hline Rondonópolis & 61.398 & 42.204 & 69 & 14.061 & 23 & 5.133 & 8 \\
\hline Alto Araguaia & 5.133 & 3.318 & 65 & 1.175 & 23 & 640 & 12 \\
\hline Canarana & 5.655 & 3.396 & 60 & 1.289 & 23 & 970 & 17 \\
\hline Barra do Garças & 17.780 & 12.157 & 68 & 4.052 & 23 & 1.571 & 9 \\
\hline Alto Garças & 3.420 & 2.123 & 62 & 758 & 22 & 539 & 16 \\
\hline Total do grupo & 258.775 & 155.483 & 60 & 75.557 & 29 & 27.735 & 11 \\
\hline Total de Mato Grosso & 915.089 & 625.674 & 68 & 185.139 & 20 & 104.276 & 12 \\
\hline
\end{tabular}


O aluguel permite um controle da posse dos imóveis por um grupo mais capitalizado, ao mesmo tempo em que permite, mesmo com dificuldades, a reprodução da mão de obra, por meio do acesso à moradia nessa condição. No entanto, reduz consideravelmente a margem financeira do trabalhador, o qual se vê obrigado a dispensar parcela considerável de seus ganhos com a habitação. As cidades mais integradas ao agronegócio se tornam cidades caras, criando uma seletividade para a permanência dos grupos sociais descapitalizados.

Considerando a região Centro-Oeste no seu conjunto, dados do IBGE referentes ao período de 2008 e 2009, coletados na Pesquisa de Orçamentos Familiares (POF), indicam que para o grupo de famílias com as mais baixas rendas (com rendimentos entre até $\mathrm{R} \$ 830,00 \mathrm{e}$ mais de $\mathrm{R} \$ 830,00$ a $\mathrm{R}$ \$ 1.245,00), os custos com a habitação representam 42,9\% e 40,3\% respectivamente do total das despesas mensais, constituindo-se como a despesa mais representativa das famílias, e que desses custos totais com habitação, o item aluguel contribui com 20,6\% (para a primeira faixa de renda) e 19,6\% (para a segunda faixa de renda), demonstrando o peso desse item no orçamento familiar (IBGE, 2010).

Portanto, mesmo tendo claro que as informações resultam do agrupamento de realidades espaço-temporais amplas (de três estados e do Distrito Federal) e relativamente defasadas (dados com mais de seis anos), o que complexifica a análise, ainda assim revelam o evidente peso no orçamento familiar da manutenção da moradia, que é um elemento fundamental para a reprodução da vida.

Ao analisar as condições do espaço como reprodução da vida Carlos (1994, p. 135) apresenta o seguinte argumento:

\begin{abstract}
A habitação, como uma das necessidades básicas e fundamentais do homem, dá-nos uma visão precisa sobre o modo de vida urbano, o local de morada associada ao preço da terra. Este será determinado pelo jogo de mercado e apoiado nos valores criados e veiculados pela sociedade num determinado momento histórico.
\end{abstract}

O acesso à habitação passa a ser diretamente proporcional às condições financeiras que permitem, ou não, que o trabalhador se torne um proprietário. Para aqueles cuja condição não favoreça a aquisição, seja de um lote urbano ou de uma casa própria, resta o recurso do aluguel, da locação da moradia, criando uma precarização das condições de reprodução da 
vida, na medida em que o trabalhador se mantém em estado de alerta quanto ao orçamento familiar para que segurança do ato de habitar esteja assegurada.

Um fator que pode estar relacionado à incidência do aluguel nos municípios destacados é o crescimento populacional, principalmente relacionado aos fluxos migratórios direcionados para essas áreas. A Tabela 8, apresenta um quadro em que é possível observar o crescimento vertiginoso de alguns municípios no período compreendido entre os anos de 1991 a 2010.

Tabela 8 - Evolução da população de municípios selecionados de Mato Grosso de 1991 a 2010

\begin{tabular}{lrrrrr}
\hline Localidade & \multicolumn{1}{c}{ Ano } & Variação & \multicolumn{1}{c}{ Ano } & Variação & \multicolumn{1}{c}{ Ano } \\
& \multicolumn{1}{c}{$\mathbf{1 9 9 1}$} & $\mathbf{1 9 9 1 - 2 0 0 0}$ & \multicolumn{1}{c}{$\mathbf{2 0 0 0}$} & $\mathbf{2 0 0 0 - 2 0 1 0}$ & \multicolumn{1}{c}{$\mathbf{2 0 1 0}$} \\
\hline Brasil & $\mathbf{1 4 6 . 8 2 5 . 4 7 5}$ & $\mathbf{1 6 \%}$ & $\mathbf{1 6 9 . 7 9 9 . 1 7 0}$ & $\mathbf{1 2 \%}$ & $\mathbf{1 9 0 . 7 5 5 . 7 9 9}$ \\
Mato Grosso & $\mathbf{2 . 0 2 7 . 2 3 1}$ & $\mathbf{2 4 \%}$ & $\mathbf{2 . 5 0 4 . 3 5 3}$ & $\mathbf{2 1 \%}$ & $\mathbf{3 . 0 3 5 . 1 2 2}$ \\
Lucas do Rio Verde & 6.693 & $189 \%$ & 19.316 & $136 \%$ & 45.556 \\
Nova Mutum & 5.542 & $167 \%$ & 14.818 & $114 \%$ & 31.649 \\
Campo Novo do Parecis & 6.311 & $179 \%$ & 17.638 & $56 \%$ & 27.577 \\
Primavera do Leste & 12.523 & $218 \%$ & 39.857 & $31 \%$ & 52.066 \\
Sapezal & - & - & 7.866 & $130 \%$ & 18.094 \\
Sorriso & 16.107 & $121 \%$ & 35.605 & $87 \%$ & 66.521 \\
Alto Taquari & 3.014 & $49 \%$ & 4.476 & $80 \%$ & 8.072 \\
Campos de Júlio & - & - & 2.895 & $78 \%$ & 5.154 \\
Campo Verde & 5.975 & $188 \%$ & 17.221 & $83 \%$ & 31.589 \\
Sinop & 38.374 & $95 \%$ & 74.831 & $51 \%$ & 113.099 \\
Tangará da Serra & 39.848 & $48 \%$ & 58.840 & $42 \%$ & 83.431 \\
Ipiranga do Norte & - & - & & - & 5.123 \\
Querência & - & - & 7.274 & $79 \%$ & 13.033 \\
Água Boa & 16.561 & $1 \%$ & 16.737 & $25 \%$ & 20.856 \\
Jaciara & 21.917 & $9 \%$ & 23.796 & $8 \%$ & 25.647 \\
Rondonópolis & 126.627 & $19 \%$ & 150.227 & $30 \%$ & 195.476 \\
Alto Araguaia & 10.770 & $6 \%$ & 11.410 & $37 \%$ & 15.644 \\
Canarana & 11.909 & $29 \%$ & 15.408 & $22 \%$ & 18.754 \\
Barra do Garças & 45.651 & $14 \%$ & 52.092 & $9 \%$ & 56.560 \\
Alto Garças & 8.306 & $0 \%$ & 8.335 & $24 \%$ & 10.350 \\
\hline Fontis
\end{tabular}

Fonte: IBGE, Cidades. Infográficos - popula ção (Censos demográficos: 1991, 2000, 2010)

Org. LIMA, Ronei C. de, 2015

Nesse contexto, municípios como Lucas do Rio Verde, Nova Mutum, Primavera do Leste, Campo Novo do Parecis, Campo Verde, Sorriso e Sapezal possuem taxas de 
crescimento populacional bastante superiores às médias nacional e estadual e, estão entre os municípios com a maior incidência de aluguel.

É possível supor que os fluxos populacionais gerados com a dinâmica econômica dessas áreas não encontrou, em um primeiro momento, o acesso direto à moradia, passando ao aluguel. Essa condição pode ser uma opção, quando de uma instalação provisória, mas pode estar relacionada com os altos custos inerentes a essas áreas pujantes do agronegócio, inclusive do preço da terra urbana e rural.

Atualmente programas públicos de moradia, como o Minha Casa Minha Vida do governo federal favorecem o acesso, mesmo que apenas parcialmente, de uma parcela da população cuja condição de moradia estava vinculada ao aluguel ou à habitação em condições precárias, contudo ainda não reduziu de forma significativa a demanda reprimida por habitação das camadas sociais menos abastadas.

De outro lado, a criação de condomínios fechados e áreas elitizadas de moradias de alto padrão em cidades como Rondonópolis, Sorriso, Lucas do Rio Verde, Nova Mutum, Primavera do Leste e outras com estreito vínculo com o agronegócio, e não somente nessas, revela ainda a condição de distribuição espacial relacionada com a condição da classe.

Essa dinâmica espacial, produzida socialmente com base na condição econômica, favorece a constituição da segregação sócio-espacial, como no caso de Rondonópolis (NEGRI, 2008), tornando-se uma realidade mais acentuada e reveladora da tentativa de homogeneizações sociais e espaciais cuja evolução está em ritmo acelerado. O fenômeno confirma o argumento de Carlos (1994, p. 135) quando aponta que “[...] a cidade é a expressão da materialização espacial das desigualdades sociais emergentes na sociedade atual”.

Se compararmos a Tabela 7, que destaca a condição dos domicílios (alugados ou próprios), com o Mapa 17 (maiores produtores de soja), podemos fazer uma relação entre o agronegócio e os altos níveis de aluguel urbano, já que doze municípios da Tabela 7, estão entre os vinte maiores produtores de soja. Se somarmos também as cidades com estreita relação com o agronegócio, como Rondonópolis e Água Boa, a concentração é intensificada. 
Mapa 17 - Os vinte maiores produtores de soja de Mato Grosso em 2014

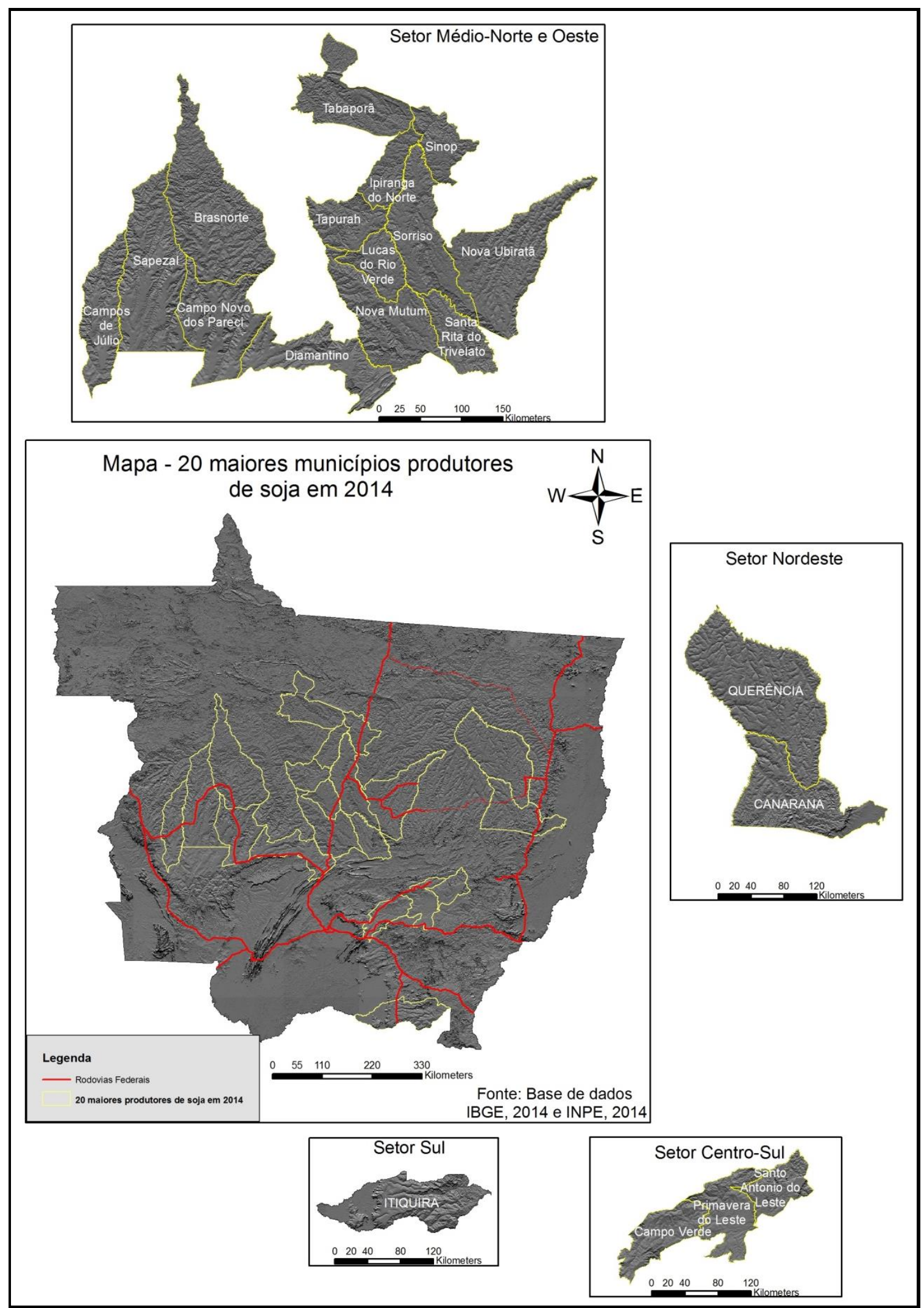

Fonte: IBGE, 2014 e IMEA, 2014 
A falta de acesso à moradia é um exemplo das contradições do agronegócio, pois há uma intensificação das relações em que o valor de troca sobressai-se em relação ao valor de uso. As dificuldades ocorrem no cotidiano do citadino simples, em sua vivência na cidade. Mas, os números do agronegócio favorecem o discurso de crescimento e de desenvolvimento, já que são superlativos e reforçam a justificativa de viés economicista.

É o caso da evolução do Índice de Desenvolvimento Humano Municipal (IDHM), que juntamente com o PIB, produz o combustível para os agentes hegemônicos justificarem seus interesses corporativos quanto às ações territoriais. Nota-se na Figura 16, que a concentração dos maiores índices do IDHM, considerando a série histórica que vai de 1991 até o ano de 2010, localiza-se ao longo das rodovias federais e nas áreas de expansão da produção de soja, algodão e milho, ou seja, nos municípios cuja base produtiva foi modernizada.

De acordo com dados do Atlas do Desenvolvimento Humano no Brasil (2013), de uma forma geral, os índices do IDHM do estado de Mato Grosso evoluíram significativamente, pois se o teto em 1991 era de 0,569 em uma escala de 0 a 1 alcançado pelo município de Cuiabá, no ano 2000 o mesmo município evolui para 0,692 e chega ao patamar de 0,785 em 2010.

Como o índice apura o seu resultado a partir de três variáveis - longevidade, educação e renda -, evolui ao contemplar elementos além da produção econômica somente, que é o caso do PIB. Porém, ainda generaliza no caso da renda, já que a mesma é calculada a partir da renda per capita, mascarando as visíveis diferenças entre as diversas classes sociais no interior de cada município.

Considerando o estado de Mato Grosso em comparação com as médias nacionais para os períodos de 1991, 2000 e 2010, o mesmo sempre apresentou índices abaixo da média nacional, como pode ser visualizado no Quadro 14. Ao mesmo tempo, um seleto grupo de municípios apresenta índices acima da média estadual e nacional, fruto de uma evolução superior dos quesitos analisados. Dos 141 municípios mato-grossenses, 49 possuíam um IDHM superior a 0,700 , considerado alto pelos critérios utilizados. 
Figura 16 - Cartograma da evolução do IDHM dos municípios de Mato Grosso

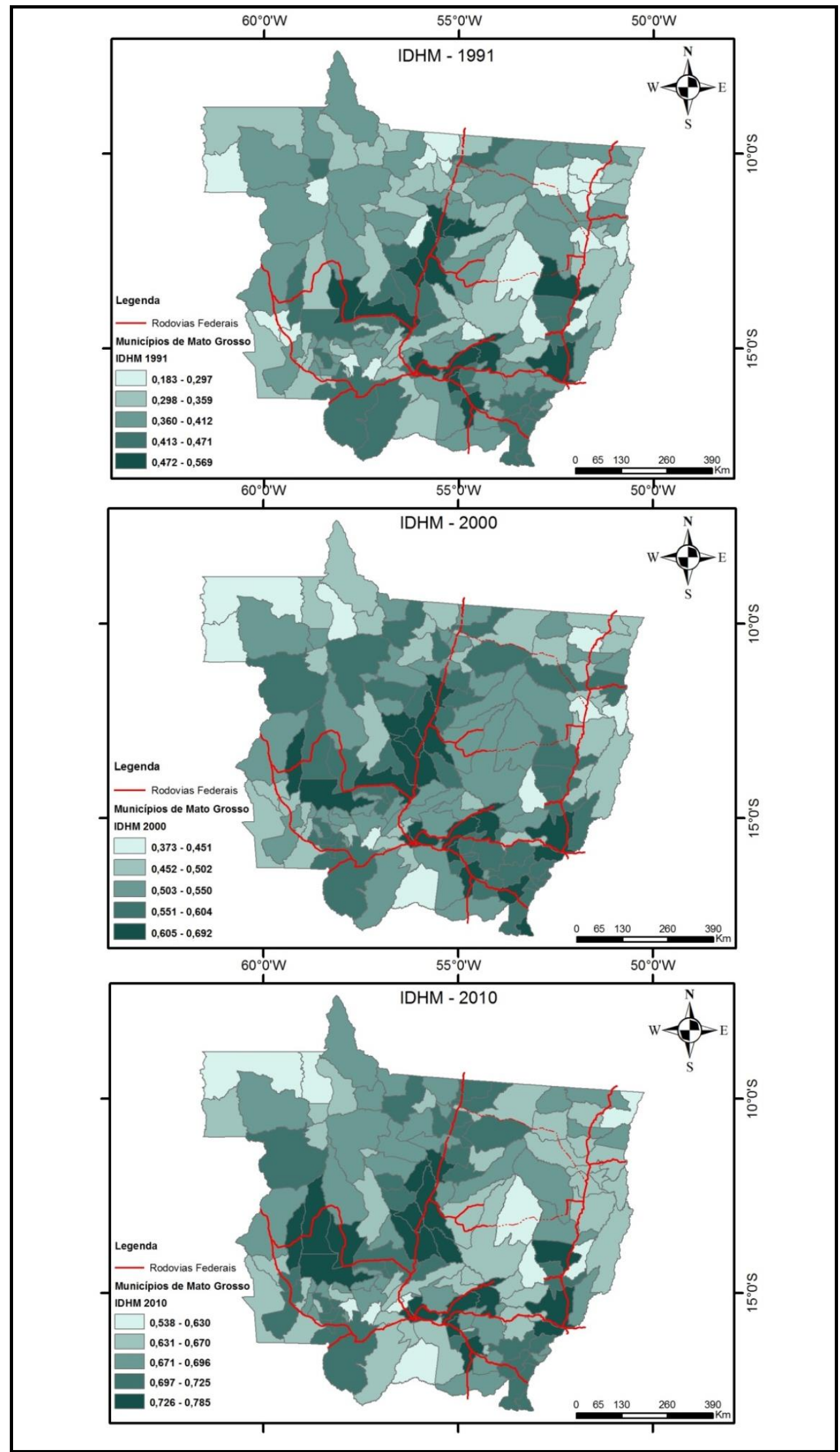

Fonte: Atlas do Desenvolvimento Humano no Brasil, 2013 


\section{Quadro 14 - IDHM de municípios selecionados de Mato Grosso}

\begin{tabular}{|l|l|l|l|}
\hline \multicolumn{1}{|c|}{ Unidade } & $\begin{array}{c}\text { IDHM } \\
\text { 1991 }\end{array}$ & $\begin{array}{c}\text { IDHM } \\
\mathbf{2 0 0 0}\end{array}$ & $\begin{array}{c}\text { IDHM } \\
\mathbf{2 0 1 0}\end{array}$ \\
\hline Brasil & $\mathbf{0 , 4 9 3}$ & $\mathbf{0 , 6 1 2}$ & $\mathbf{0 , 7 2 7}$ \\
\hline Mato Grosso & $\mathbf{0 , 4 4 9}$ & $\mathbf{0 , 6 0 1}$ & $\mathbf{0 , 7 2 5}$ \\
\hline Cuiabá & 0,569 & 0,692 & 0,785 \\
\hline Lucas do Rio Verde & 0,549 & 0,658 & 0,768 \\
\hline Nova Mutum & 0,432 & 0,640 & 0,758 \\
\hline Rondonópolis & 0,480 & 0,638 & 0,755 \\
\hline Sinop & 0,500 & 0,626 & 0,754 \\
\hline Primaverado Leste & 0,507 & 0,637 & 0,752 \\
\hline Campo Verde & 0,521 & 0,638 & 0,750 \\
\hline Barra do Garças & 0,491 & 0,631 & 0,748 \\
\hline Campos de Júlio & 0,460 & 0,636 & 0,744 \\
\hline Sorriso & 0,517 & 0,664 & 0,744 \\
\hline Jaciara & 0,495 & 0,634 & 0,735 \\
\hline Santa Rita do Trivelato & 0,316 & 0,596 & 0,735 \\
\hline Campo Novo do Parecis & 0,495 & 0,595 & 0,734 \\
\hline Pontal do Araguaia & 0,384 & 0,607 & 0,734 \\
\hline Várzea Grande & 0,471 & 0,620 & 0,734 \\
\hline Sapezal & 0,341 & 0,601 & 0,732 \\
\hline Água Boa & 0,426 & 0,603 & 0,729 \\
\hline Tangará da Serra & 0,443 & 0,621 & 0,729 \\
\hline
\end{tabular}

Fonte: Atlas do Desenvolvimento Humano no Brasil, 2013

No outro extremo, em 2010, os municípios de Campinápolis $(0,538)$, Nova Nazaré $(0,595)$ e Porto Estrela $(0,599)$ possuíam índices que os colocavam na faixa de baixo índice de desenvolvimento humano. Enquanto os dois primeiros, localizados nas imediações da BR158, apresentavam como pior desempenho o quesito educação, o último, situado nas proximidades a BR-070 e orbitando na área de influência de Cáceres, possuía no quesito renda sua marca menos expressiva.

Esses dados precisam ser considerados com cuidado, pois não conseguem apresentar um cenário preciso da realidade de cada município, cidade ou região do estado de Mato Grosso, visto que a complexidade e as especificidades de cada local impede compreendê-los a partir apenas dos dados estatísticos, mas esses nos dão a pista da ocorrência dos processos de concentração e centralização.

Pois, se compararmos os mapas que nos dão uma representação espacial dos fenômenos em dado instante, é notório como alguns municípios e cidades ou mesmo regiões (caso do Meio-Norte mato-grossense) surgem repetidas vezes em diversas análises, indicando que de fato ocorrem os processos de concentração geográfica: da produção; do estabelecimento de fixos voltados à produção - plantas industriais, armazéns, frigoríficos -; e 
dos investimentos no sistema de engenharia de transportes - rodovias federais BR-163 e BR364 e ferrovia (nesse caso na porção Sul do estado).

Da mesma forma, os melhores índices de IDHM, PIB e crescimento populacional se concentram em áreas dinâmicas nos eixos rodoviário e ferroviário, indicando que o conjunto produção e sistemas de engenharia de transportes é o grande catalizador do crescimento de cidades, municípios e regiões específicas de Mato Grosso.

Já a centralização, entendida a partir do controle e da gestão de capitais, ocorre em níveis diversos. Temos no nível local algumas cidades que compõem os círculos de cooperação do capital quanto ao estabelecimento do controle de unidades produtivas e do apoio quanto a certos serviços demandados, caso de Rondonópolis, Cuiabá, Sinop. Nessas se concentram alguns setores de pesquisa, de formação de mão de obra e de apoio na logística de transportes.

No nível nacional, São Paulo responde por dupla gestão, uma intermediária, quanto ao capital internacional e outra hegemônica em grande parte dos capitais nacionais.

Mas, o maior controle e a gestão mais abrangente ocorrem no nível internacional, a partir das cidades que sediam as grandes corporações, que no caso do agronegócio controlam a quase totalidade do processo produtivo e influenciam diretamente setores como o da distribuição, circulação e consumo, tornando corporativas as ações no território, mesmo que de forma remota.

Assim, no seio de um projeto nacional de modernização, que ganha vulto a partir dos anos 1970, reforça-se a corporatização do território, pois este é equipado para ser usado por todos, mas segundo Santos (2008b, p. 118) o que difere esse uso é o poder de cada grupo, logo:

[...] o território não é apenas o teatro do jogo econômico; ele se torna fator determinante. Tal como ele se organiza para a modernidade, o território é a base comum de operação para todos os atores, mas é sobretudo favorável às corporações.

E assim, o mesmo processo promove o surgimento das chamadas cidades corporativas, favorecidas pelas mudanças oriundas de uma "ideologia do crescimento" e de uma "prática da 
modernização" (SANTOS, 2008, p. 117) cujo conteúdo cria as condições ideais para que as grandes empresas nacionais e internacionais possam operar com o apoio do Estado. No mesmo movimento temos alterações significativas das estruturas urbanas, agora preparadas para a função pensada pelos agentes hegemônicos para cada uma na divisão territorial do trabalho.

Em suma, as cidades mato-grossenses mais integradas refletem esse quadro, cujo movimento é maior e não se restringe às escalas locais, regionais ou nacionais, mas sim a um arranjo mais amplo e complexo, regido pelas imposições de caráter global. A complexidade das articulações, que se tornam mais densas em virtude da globalidade das ações, promove a integração e, contraditoriamente, a desintegração, na medida em que os processos seguem uma lógica distante e pouco comprometida com o local.

Nesse sentido, as mudanças contínuas exigidas para reprodução do capital, como os ajustes espaciais demandados, promovem um quadro de instabilidade constante na medida em que são geridas pelos interesses corporativos. Logo as relações existentes, entre o local e o global, estão baseadas em constante conflito de forças, como a necessidade de melhores condições de trabalho e de reprodução da vida dos trabalhadores, e as questões ambientais e culturais que configuram um conjunto complexo e importante, que é refratário ao discurso meramente econômico pautado na premissa de redução de custos.

Já as demais áreas, mesmo caracterizadas pela menor integração, também participam do processo, por se constituírem como uma reserva estratégica, a reserva de lugares, esperando serem acionadas pelos agentes hegemônicos. Nesse ínterim, enfrentam problemas estruturais de toda natureza, visto que não são interessantes ao capital e logo ficam à margem de receber uma melhor dotação de infraestruturas por parte dos agentes hegemônicos. Com isso, têm as suas condições de reprodução social prejudicadas em um processo lento e contínuo, implicando na sua condição de marginalidade. 


\section{CONSIDERAÇÕES FINAIS}

Após efetuarmos uma análise dos processos advindos dos ajustes capitalistas sobre o território, entendemos que esses levaram a uma corporatização do território mato-grossense, a partir da sua reestruturação com vistas a atender aos interesses dos agentes hegemônicos, quais sejam, as grandes corporações e o Estado.

Destarte, foi possível observar que as politicas públicas empregadas no processo estavam em consonância com as mudanças estruturais em curso no capitalismo mundial, ou seja, faziam parte do movimento interno de reorganização com vistas à manutenção da reprodução ampliada do capital, resultando em uma produção espacial desigual.

Mato Grosso recebeu investimentos do Estado, principalmente nos setores de infraestrutura de transportes, energia e comunicações, e também passou a integrar o processo de modernização da agricultura, movimento já estabelecido nas regiões Sudeste e Sul do Brasil, cujo transbordamento estava sincronizado com as novas demandas internacionais por matérias-primas e por novos mercados. A busca por novos mercados foi uma das estratégias da fase de flexibilização do capitalismo mundial.

No entanto, a transição ocorrida no interior do capitalismo foi gerada no meio de uma grave crise do sistema, ocasionando desdobramentos que repercutiram diretamente no Brasil e na reestruturação mato-grossense. Assim, entendemos que houve uma interrupção no projeto de reestruturação, o que a tornou incompleta.

A redução dos recursos disponíveis levou o Estado a tomar medidas com vistas à sua otimização, ou seja, esses recursos foram concentrados nas áreas estratégicas, principalmente na conformação dos corredores de exportação, posteriormente denominados de eixos de desenvolvimento, e finalmente nos vetores logísticos.

Em comum as três denominações (substancialmente equivalentes) apresentam um caráter extrovertido, provocador de rebatimentos diretos no território, pois causa o seu enrijecimento para um fim cujo controle foge à esfera nacional, se posicionando no interior de grandes corporações capitalistas, em detrimento de um ganho social mais amplo no nível interno. 
Programas como o I e II PNDs, o PNLT e o PAC1 e PAC2, foram aqueles que produziram as mudanças mais significativas, pois dotou o território de sistemas de engenharia sem os quais a inserção de Mato Grosso no meio técnico-científico-informacional seria menos intensa e mais lenta.

Enquanto os PNDs criaram a primeira etapa da infraestrutura, o PNLT e o PAC retomam os investimentos e corroboram com a proposta de um crescimento voltado para fora, visto que não integra de forma mais efetiva as regiões menos articuladas e cujo retorno econômico seja menor, embora o discurso indique um caminho diferente.

Mas, a análise indica a existência de uma visão racional consoante com o mundo corporativo, exemplificado pelas concessões e pelos investimentos efetuados em setores e locais estratégicos do ponto de vista do setor produtivo, que poderia ser justo caso houvesse uma contrapartida de ganhos sociais mais efetivos.

Quanto aos impactos resultantes desse processo de reestruturação do território, ficou evidente que houve uma acentuação da diferenciação entre os lugares. Esse processo faz parte da lógica capitalista, pois nem todos os lugares estavam aptos para atender as demandas do novo modelo produtivo.

Enquanto o Sudeste mato-grossense tem em Rondonópolis seu epicentro e porta de entrada da agricultura tecnificada e cientificizada, observamos que essa área consolidada apresenta seus limites no que tange à expansão produtiva, porém concentra o mais importante parque fabril do agronegócio, o melhor sistema de engenharia de transportes, bem como serviços elaborados voltados ao setor produtivo.

Essa concentração está relacionada à posição estratégica atual, que é mais próxima da área mais dinâmica do país, e pelo sistema de engenharia de transportes mais denso, visto que possui a intermodalidade formada por rodovias e ferrovia.

No entanto, as dinâmicas mais intensas são estabelecidas em outras regiões do estado, principalmente em parte do Oeste, do Nordeste, mas principalmente no Médio-Norte, região que concentra a maior parte da produção, dos fixos voltados à produção (principalmente de armazéns) e parte importante do parque fabril do agronegócio, principalmente da cadeia carne-grãos. 
Enquanto parte dos produtores do Oeste mato-grossense já criou sua rota de exportação, por meio da intermodalidade entre a via rodoviária (BR-364) e a via hidroviária (Madeira) com expressiva redução de custos, o Nordeste e principalmente o Médio-Norte buscam uma alternativa às grandes distâncias da rota Norte-Sul.

A inversão da logística de transportes para o sentido Sul-Norte, com a intermodalidade proporcionada pelo pleno uso da rodovia (BR-163) e hidrovia (Amazonas - via portos de Miritituba e Santarém), é o principal objetivo do setor produtivo e das tradings que atuam no agronegócio brasileiro, que passam a exigir do Estado a celeridade nos projetos referentes a esses corredores de exportação.

Com a efetivação da nova rota, cidades como Lucas do Rio Verde (onde haverá um terminal da ferrovia FICO e/ou um terminal da ferrovia ligando essa cidade à Miritituba), Sorriso e Sinop apresentarão uma maior centralidade no agronegócio mato-grossense e reduzirão significativamente a centralidade hoje exercida por Rondonópolis.

A possibilidade de migração de empresas de diversas naturezas, como agroindústrias e transportadoras, para o novo eixo é bastante provável, pois a mobilidade do capital é bastante efetiva nesse sentido, mesmo com o capital fixo já investido em certos lugares, pois se trata de estar nos lugares luminosos e mais suscetíveis à reprodução do capital.

Um exemplo desse movimento pode ser percebido em Alto Araguaia, município que recebeu expressivos investimentos por conta da instalação do terminal ferroviário, mas que, após o início do funcionamento do terminal de Rondonópolis, passa por uma fase de redução das atividades produtivas. Como reflexo, os investimentos do poder público municipal tendem ao contingenciamento, atingido principalmente as camadas mais pobres cuja demanda cresceu nos últimos anos.

Analisando a dinâmica da logística de transportes existente em Mato Grosso, é possível afirmar, a partir da maior aproximação em relação ao fenômeno proporcionado por essa pesquisa, que a integração entre os modais está se dando de forma gradativa, pois quem define de fato a composição dos fluxos e o seu direcionamento são as tradings, cabendo aos demais transportadores e à concessionária do sistema ferroviário, nesse caso a ALLMN, prestar o serviço de transportes de acordo com os contratos pré-determinados.

Já o produtor rural, a quem fora vendida a ideia de que o novo modal iria provocar uma redução dos custos de transporte, ainda não obteve nenhuma vantagem com a integração 
de modais. Esse fato decorre da forma como é negociada a produção com as tradings, já que são elas que determinam o preço final ao produtor já com o desconto dos custos de transportes. Assim, as vantagens da existência da intermodalidade de transportes são repassadas para esses agentes hegemônicos, que se utilizam de estratégias diversas para reduzir custos e manter os fluxos de commodities conforme a demanda do mercado.

No que tange aos gargalos logísticos, fenômeno que impulsiona as demandas por novas articulações e estratégias de ação de produtores e tradings, verifica-se que os mesmos provocam um descompasso na fluidez corporativa, aumentando o tempo de circulação do capital e com isso retardando a sua realização, visto que o processo produtivo só completa o seu ciclo com o consumo.

Esses gargalos estão territorializados em Mato Grosso de formas diversas: nos impedimentos da movimentação de granéis por conta da inadequação das vias às novas demandas rodoviárias; pela demora na realização de projetos prioritários aos interesses corporativos (hidrovias, ferrovias e readequação do modal rodoviário). O problema é potencializado pelas condições precárias da infraestrutura portuária, bem como da falta de segurança jurídica quanto à normatização dos investimentos nos setores cujas concessões dão continuidade a um processo já em curso.

Diante desse quadro, o setor corporativo busca assegurar a sua viabilidade com a consecução de estratégias diversas, como a associação entre empresas para investimentos logísticos fundamentais (estações de transbordo de cargas, terminais portuários, estruturas de transportes e armazenagem) para a criação, expansão e manutenção das redes de fluxos materiais e imateriais; a territorialização nos pontos nodais (nas áreas de produção, nas vias de circulação e nos terminais exportadores); e o repasse dos custos de transportes para os produtores, pois descontam no preço pago essas despesas.

Por isso a luta das entidades representativas do setor produtivo do agronegócio, sintetizados pelo Movimento Pró-Logística que busca alternativas que favoreçam a redução dos custos com transportes e armazenagem do produtor, é tão incisiva e tenta, com ações diversas, articular suas propostas com a sociedade como um todo, por meio de audiências, reuniões e visitas às áreas demandantes de investimentos, para mostrar as vantagens das propostas do setor para as comunidades envolvidas, cujos territórios podem ser atravessados pelos novos fluxos gerados. 
Para o setor corporativo, a redução de custos é tão essencial quanto a manutenção dos diversos fluxos necessários à operacionalidade dos negócios, por isso investem em alternativas de rotas diferenciadas, intermodais e racionais com as suas necessidades empresariais. Ao setor produtivo do agronegócio, a redução dos custos é crucial para a sua capitalização e, consecutivamente, para a sua segurança em meio às variações do mercado, que são oriundas das oscilações globais inerentes à natureza do processo produtivo em questão.

Quanto aos desdobramentos territoriais decorrentes dessas dinâmicas, observa-se que os fenômenos são mais intensos nos eixos de escoamento, conforme planejado pelo Estado, demonstrando que a existência prévia de sistemas de engenharias diversas (caso de Rondonópolis no Sul do estado) e as possibilidades futuras (caso do eixo da BR-163 no Médio-Norte com a perspectiva da FICO) criam um conjunto seleto de lugares luminosos.

Esses lugares são compostos por cidades próximas, ou estruturalmente articuladas com as principais áreas produtoras, que dão suporte ao setor produtivo, pois estão voltadas ao atendimento das necessidades do agronegócio ao intermediar a disponibilização de bens e serviços necessários ao seu funcionamento - portanto mais integradas aos circuitos produtivos e círculos de cooperação do capital. Caracterizam-se por apresentar um controle da terra urbana que implica na dificuldade de acesso à moradia própria, elevando a taxa de aluguel; pela predominância de elevados índices de IDHM e PIB, que cria o elemento ideológico propício às elites locais justificarem suas ações sobre o território; e pelo crescimento populacional notadamente urbano.

Essa realidade, por sua vez, é parcial, pois não ocorre na totalidade do território, implicando na existência de um crescimento desigual no território mato-grossense, já que grandes áreas ainda são caracterizadas pela opacidade.

A opacidade existente se dá inicialmente pela seletividade do capital em relação aos lugares e, portanto, dos investimentos públicos e privados que são atraídos por ele. Assim, o meio rural, e por consequência o meio urbano, desses lugares não possuem uma articulação efetiva com os projetos estruturantes efetivados. Nesse sentido, ficam à margem desses processos os pequenos produtores que ainda resistem nos interstícios das grandes propriedades empresariais do agronegócio, pois mesmo intercalando as suas propriedades e produções no território usado pelas corporações e pelos grandes produtores, não são atendidos 
pelos projetos efetivados no sistema logístico (transporte - excetuando-se o acesso ao modal rodoviário, porém esse passa a ter custos adicionais com pedágios - e armazenagem).

Dessa forma, a logística do pequeno, como denomina Becker (2007), não faz parte dos planos do Estado e das corporações. Das corporações é esperado esse posicionamento, já que os pequenos produtores rurais em Mato Grosso não são fornecedores de commodities, e por isso não estão nos planos das tradings (exceto quando existe a necessidade de selos sociais, como no caso da produção de biodiesel). No entanto, o Estado, que deveria representar a totalidade da sociedade, também não procura integrar essa parcela produtora, tornando a utilização mais efetiva do território quase exclusiva do setor corporativo.

Mas, é esse o conteúdo da racionalidade proposta e efetivada pelos agentes hegemônicos, cujos resultados apontam para um crescimento econômico absoluto, real e tangível. No entanto, um desenvolvimento social mais pleno e integrador não se estabelece, pois que se revela apenas pontual, territorializado em locais específicos e direcionado para grupos privilegiados, logo a sua totalidade caracteriza-se pela parcialidade dos ganhos sociais, e portanto, geradora de um desenvolvimento apenas relativo. 


\section{REFERÊNCIAS}

ABREU, Silvana de. Planejamento governamental: a Sudeco no espaço mato-grossense: contexto, propósitos e contradições. 2001. 323 f. Tese (Doutorado em Geografia) - Faculdade de Filosofia, Letras e Ciências Humanas, Universidade de São Paulo, São Paulo, 2001.

AFONSO, José Roberto R. et al. A renúncia tributária do ICMS no Brasil. Banco Interamericano de Desenvolvimento (BID), Documento para discussão. 2014. Disponível em: $<$ http://publications.iadb.org/bitstream/handle/11319/6350/FMM\%20

DP\%20A\%20ren\%C3\%BAncia\%20tribut\%C3\%A1ria\%20do\%20ICMS\%20no\%20Brasil.pdf ?sequence=1>. Acesso em: 20 jul. 2014.

ARACRI, Luís Angelo dos Santos; MOREIRA, Fernando de Souza. Considerações metodológicas sobre o estudo do circuito espacial da bovinocultura de corte em Mato Grosso. In: BERNARDES, Júlia Adão; ARACRI, Luís Angelo dos Santos. (Org.). Espaço e circuitos produtivos: a cadeia carne/grãos no cerrado mato-grossense. Rio de Janeiro: Arquimedes, 2010. cap. 5, p. 75-88.

ARAÚJO, Tania Bacelar. Brasil nos anos noventa: opções estratégicas e dinâmica regional. In: Revista brasileira de estudos urbanos e regionais. Rio de Janeiro, ano 1, n. 2, p.9-24, nov. 1999. Disponível em: <http://www.anpur.org.br/revista/rbeur/index. php/rbeur/article/view/34/20> $>$. Acesso em: 05 maio 2014.

A experiência de planejamento regional no Brasil. In: LAVINAS, Lena; CARLEIAL, Liana Maria da Frota; NABUCO, Maria Regina. (Org.). Reestruturação do espaço urbano e regional no Brasil. São Paulo: Hucitec, 1993. p. 87-95.

ARRAIS, Tadeu Alencar. A produção do território goiano: economia, urbanização, metropolização. Goiânia: Editora UFG, 2013.

ARROYO, Mónica. Território brasileiro e mercado externo: uma leitura dessa relação na virada do século XX. In: SOUZA, Maria Adélia de (Org.). Território brasileiro: usos e abusos. Campinas: Edições Territorial, 2003. cap. 26, p. 428-457.

ARRUDA, Zuleika Alves de. Onde está o agro desse negócio?: Transformações socioespaciais em Mato Grosso decorrentes do agronegócio. 2007. 277 f. Tese (Doutorado em Ciências) - Instituto de Geociências, Universidade Estadual de Campinas, Campinas, 2007. Disponível em: <http://www.bibliotecadigital.unicamp.br/document/?code=vtls000417779 $\underline{\& d=y}>$. Acesso em: 05 ago. 2014.

Associação Brasileira das Indústrias Exportadoras de Carne (ABIEC). Mapa das plantas. Disponível em: <http://www.abiec.com.br/mapadasplantas.asp>. Acesso em: 25 maio 2014.

Associação Nacional dos Transportadores Ferroviários (ANTF). Associadas. ALL. ALLMN. Disponível em: <http://www.antf.org.br/pdfs/Ferronorte.pdf>. Acesso em: 09 jul. 2014.

Associação Nacional dos Usuários do Transporte de Carga (ANUT). Transporte - desafio ao crescimento do agronegócio brasileiro. Brasília, 2008. Disponível em: 
<http://www.tgl.ufrj.br/projetos/biblio/ANUT_Desafio___Crescimento_Agronegocio_Br asileiro_2008.pdf>. Acesso em: 25 jul. 2014.

ATLAS do Desenvolvimento Humano no Brasil, 2013. Disponível em: < http://www.atlasbrasil.org.br/2013/pt/home/>. Acesso em 25 ago. 2014.

BALLOU, Ronald H. Logística empresarial: transportes, administração de materiais e distribuição física. São Paulo: Atlas, 2012.

BARAT, Josef. Infraestruturas de logística e transporte: análise e perspectivas. In: SILVEIRA, Márcio Rogério. (Org.). Circulação, transportes e logística: diferentes perspectivas. São Paulo: Outras Expressões, 2011. cap. 6, p. 217-246.

O setor de transportes na economia brasileira. Revista de Administração Pública. Rio de Janeiro. 7(4): 105-199, out./dez. 1973. Disponível em: <http://bibliotecadigital.fgv.br/ojs/index.php/rap/article/view/5931/ 4603 >. Acesso em: 23 maio 2014.

BECKER, Berta. K. Logística e Nova Configuração do Território Brasileiro: Que Geopolítica Será Possível? In: DINIZ, C. C. (Org.). Políticas de Desenvolvimento Regional: desafios e perspectivas à luz das experiências da União Europeia e do Brasil. Brasília: Ministério da Integração - IICA, 2007. 400p., p. 267-299.

Fronteira e urbanização repensadas. Revista Brasileira de Geografia. Rio de Janeiro, v. 60, n. 1-2, jan./dez., 2006. pp. 396-412.

Logística: uma nova racionalidade no ordenamento do território? Anais do $3^{\circ}$ Simpósio Nacional de Geografia Urbana. Rio de Janeiro: AGB, 1993. Disponível em: <http://biblioteca.ibge.gov.br/ visualizacao/livros/liv23816.pdf>. Acesso em: 07 maio 2014.

BECKER, Bertha K.; EGLER, Cláudio A. G. Brasil: uma nova potência regional na economia-mundo. Rio de Janeiro: Bertrand Brasil, 1993.

BECKMANN, Elizangela. Estudo da cadeia produtiva do arroz de Mato Grosso: impactos do setor de beneficiamento na economia regional em 2011. 2011. Cuiabá: UFMT, 2011. (Dissertação de Mestrado).

BENKO, Georges. Economia, espaço e globalização: na aurora do século XXI. 3. Ed. São Paulo: Hucitec, 2002.

BERNARDES, Júlia Adão. Novas fronteiras do capital no Cerrado: dinâmica e contradições da expansão do agronegócio na região Centro-Oeste, Brasil. In: Scripta Nova. Revista Electrónica de Geografía y Ciencias Sociales. Barcelona, vol. 19, n. 507, 2015. Disponível em: <http://www.ub.edu/geocrit/sn/sn-507.pdf> Acesso em: 29 jun. 2015.

. O novo tempo do capital no cerrado: a criação de novos territórios produtivos. In: BERNARDES, Júlia Adão; ARACRI, Luís Angelo dos Santos. (Org.). Espaço e circuitos produtivos: a cadeia carne/grãos no cerrado mato-grossense. Rio de Janeiro: Arquimedes, 2010. cap. 1, p. 15-27. 
Crise no agronegócio: novas ações, novos tempos, novas territorialidades. In: OLIVEIRA, Márcio Piñon de; COELHO, Maria Célia Nunes; CORRÊA, Aureanice de Mello (Org.). O Brasil, a América Latina e o mundo: espacialidades contemporâneas (II). Rio de Janeiro: Lamparina: Anpege, Faperj, 2008. 446 p., p. 254-265.

BLANCO, Jorge; RODRIGUES, Diego. Territory, transportation and logistic integration: an approach to the argentinean case. Terrae, Campinas. v. 8, n. 1-2, p. 3-12, 2011. Disponível em: 〈http://www.ige.unicamp.br/terrae/V8/PDF-N8/Jorge\%20 Blanco.pdf>. Acesso em: 09 mar. 2015.

BORDIN, Luís Carlos Vitali. ICMS: gastos tributários e receita potencial. Brasília: ESAF, 2003. 51 p. Disponível em: <http://www3.tesouro.fazenda.gov.br/Premio_TN/VIIIPremio/ sistemas/MHafdpVIIIPTN/mh_pemio_tosi.pdf>. Acesso em: 20 jul. 2014.

BRAGA, Vanderlei; CASTILLO, Ricardo. Tipologia e topologia de nós logísticos no território brasileiro: uma análise dos terminais ferroviários e das plataformas multimodais. Boletim Campineiro de Geografia. V. 3, n. 2, 2013. Disponível em: <http://agbcampinas.com.br/bcg/index.php/boletim-campineiro/article/view/112/pdf_7 >. Acesso em: 02 mar. 2015.

BRASIL. Ministério do Desenvolvimento, Indústria e Comércio Exterior (MDIC). Secretaria de Comércio Exterior. AliceWeb. Consulta. Exportação. (2015). Disponível em: <http://aliceweb.mdic.gov.br//index/home>. Acesso em: 08 jun. 2015.

. Ministério dos Transportes. Agência Nacional de Transportes Terrestres (ANTT). Concessões rodoviárias. (2014a). Disponível em: <http:// www.antt.gov. br/index.php/content/view/29451/CRO_Concessionaria_Rota_do_Oeste_S_A_html >.

Acesso em: 29 jun. 2014.

Ministério dos Transportes. Política de Transporte. PIL - Programas de Investimento em Logística. Novos trechos rodoviários (2014b). Disponível em: <http://www.transportes.gov.br/conteudo/108989>. Acesso em: 29 jun. 2014.

Ministério dos Transportes. Política de Transporte. PIL - Programas de Investimento em Logística. Concessões rodoviárias (2014c). Disponível em: <http://www.transportes.gov.br/conteudo/101907>. Acesso em: 29 jun. 2014.

Ministério dos Transportes. Agência Nacional de Transportes Terrestres (ANTT). Infraestrutura Ferroviária. Acompanhamento das Concessões Ferroviárias. Relatório Anual de 2013. (2014d). Disponível em: <http://www.antt.gov.br/index.php/ content/view/4994/Relatorios_Anuais.html>. Acesso em: 7 jul. 2014.

Ministério dos Transportes. Agência Nacional de Transportes Terrestres (ANTT). Infraestrutura Ferroviária. Evolução do Transporte Ferroviário. (2014e). Disponível em: $<$ http://www.antt.gov.br/index.php/content/ view/15884/Evolucao_do _Transporte_Ferroviario.html>. Acesso em: 7 jul. 2014.

Ministério dos Transportes. Agência Nacional de Transportes Terrestres (ANTT). Infraestrutura Ferroviária. Concessões: Edital e Contratos. (2014f). Disponível em: 
<http://www.antt.gov.br/index.php/content/view/11924/Edital_e_CContratos.html $>$. Acesso em: 07 mar. 2014.

- Ministério dos Transportes. Departamento Nacional de Infraestrutura de Transportes (DNIT). Condições das Rodovias: Pará. (2014g). Disponível em: $<$ http://www1.dnit.gov.br/rodovias/condicoes/condicoesdrf.asp?BR=163\&Estado=Par \%E1\&drf=2>. Acesso em: 25 jul. 2014.

. Ministério dos Transportes. VALEC - Engenharia, Construções e Ferrovias S.A. Ações e Programas - Ferrovias Valec (2014h). Disponível em: <http://www.valec.gov.br/acoes_programas/>. Acesso em: 28 jul. 2014.

Ministério do Planejamento. PAC. Energia. Geração de energia elétrica. Mato Grosso. 2014i. Disponível em: <http://www.pac.gov.br/energia/geracao-de-energiaeletrica/mt>. Acesso em: 19 jun. 2015.

. Ministério do Planejamento. PAC. Hidrovias Mato Grosso. 2014j. Disponível em: <http://www.pac.gov.br/transportes/hidrovias/mt>. Acesso em: 09 jun. 2015.

Ministério dos Transportes. Secretaria de Política Nacional de Transportes SPNT/MT. Plano Hidroviário Estratégico. Relatório do Plano. Brasília: Ministério dos Transportes, 2013.

Ministério dos Transportes. Secretaria de Política Nacional de Transportes SPNT/MT. Plano Nacional de Logística e Transportes: Projeto de Reavaliação de Estimativas e Metas do PNLT: Relatório final. Brasília: Ministério dos Transportes, 2012.

Ministério do Planejamento, Orçamento e Gestão. Secretaria de Planejamento e Investimentos Estratégicos - SPI. Relatório de Avaliação do Plano Plurianual 2004-2007: exercício 2008 - ano base 2007. Brasília: MP, 2008.

Ministério do Planejamento, Orçamento e Gestão. Secretaria de Planejamento e Investimentos Estratégicos. Plano plurianual 2008-2011: projeto de lei. Brasília: MP, 2007a. Disponível em: <http://www.Planejamento.gov.br/secretarias/upload/ Arquivos/spi/plano_plurianual/PPA/081015_PPA_2008_mesPres.pdf $>$. Acesso em: 08 maio 2014.

Ministério dos Transportes e Ministério da Defesa. Plano Nacional de Logística e Transportes: relatório executivo. Tecnologia e participação para o desenvolvimento. Brasília: Ministério dos Transportes e Ministério da Defesa, 2007b.

Lei $\mathrm{N}^{\circ}$ 9.276, de 9 de maio de 1996a. Dispõe sobre o Plano Plurianual para o período de 1996/1999 e dá outras providências. Disponível em: < http://www.planalto.gov.br/ccivil_03/Leis/L9276.htm>. Acesso em: 05 mai. 2014.

Lei $\mathrm{N}^{\circ}$ 9.277, de 10 de maio de 1996b. Autoriza a União a delegar aos municípios, estados da Federação e ao Distrito Federal a administração e exploração de rodovias e portos federais. Disponível em: 〈http://www.planalto.gov.br/ccivil_03/ leis/L9277.htm>. Acesso em: 29 jun. 2014. 
Ministério do Interior, Superintendência do Desenvolvimento da Região CentroOeste - Sudeco, II Plano Nacional de Desenvolvimento, Programa de Ação do Governo para a Região Centro-Oeste (1975-1979), Brasília, Junho, 1975 a.

Decreto $n^{\circ} 75.320$, de 29 de janeiro de 1975 . Dispõe sobre a criação do Programa de Desenvolvimento dos Cerrados (POLOCENTRO). Diário Oficial da União, Brasília, 30 jan. 1975b. Seção 1. Disponível em: <http://www2.camara.leg.br/legin/fed/ decret/19701979/decreto-75320-29-janeiro-1975-423871-publicacaooriginal-1-pe.html>. Acesso em: 25 abr. 2014.

CAETANO, Mariana. Armazenagem move união de produtores em Mato Grosso. Valor Econômico. 28 de novembro de 2013. Disponível em: <http: // www.valor.com.br/agro/3354790/armazenagem-move-uniao-de-produtores-em-matogrosso\#ixzz2o4CJQGXK>. Acesso em: 20 dez. 2013

CALAÇA, Manoel; INOCÊNCIO, Maria Erlan. "Estado e território no Brasil: reflexões a partir da agricultura no Cerrado". In: Revista IDeAS - Interfaces em Desenvolvimento, Agricultura e Sociedade, Rio de Janeiro - RJ, v. 4, n. 2, 2010. pp. 271-306. Disponível em: <http://r1.ufrrj.br/cpda/ ideas/revistas/v04/n02/IDeAS-v04_n02-Artigo_ INOCENCIO_e_CALACA.pdf>. Acesso em: $01 \mathrm{dez} 2013$.

CALLADO, Antônio André Cunha; CALLADO, Aldo Leonardo Cunha. Sistemas agroindustriais. In: CALLADO, Antônio André Cunha (Org.). Agronegócio. 3. ed. São Paulo: Atlas, 2011. 203p.

CAMPOS, Margarida de Cassia. O papel do Estado brasileiro na expansão do complexo da soja. Anais XXI Colóquio Internacional de Geocrítica, 2012. Bogotá 7 a 11 de mayo de 2012.

CAMPOS, Flávia Rezende; ALMEIDA, Denise Vaz de. A integração da economia goiana a partir do sistema ferroviário: uma análise da Estrada de Ferro Goiás e da Ferrovia Norte-Sul. DOI 10.5216/ag.v8i2.29296. Ateliê Geográfico, [S.1.], v. 8, n. 2, p. 65-91, ago. 2014. ISSN 1982-1956. Disponível em: <http://revistas.ufg.br/index.php/ atelie/article/view/29296/17133>. Acesso em: 19 fev. 2015.

CANO, Wilson. Novas determinações sobre as questões regional e urbana após 1980. In: Revista brasileira de estudos urbanos e regionais. Rio de Janeiro, v. 13, n. 2, p.27-53, nov. 2011. Disponível em: <http://www.anpur.org.br/revista/rbeur/index.php/ rbeur/article/view/393/369>. Acesso em: 05 Mai. 2014.

CARLOS, Ana Fani Alessandri. A (Re)Produção do espaço urbano. São Paulo: Editora da Universidade de São Paulo, 1994.

CASTILLO, Ricardo. Agricultura globalizada e logística nos cerrados brasileiros. In: SILVEIRA, Márcio Rogério (Org.). Circulação, transportes e logísticas: diferentes perspectivas. São Paulo: Outras Expressões, 2011. cap. 10, p. 331-354.

Sustentabilidade, desenvolvimento e globalização. In: OLIVEIRA, Márcio Piñon de; COELHO, Maria Célia Nunes; CORRÊA, Aureanice de Mello (Org.). O Brasil, a América Latina e o mundo: espacialidades contemporâneas (I). Rio de Janeiro: Lamparina: Anpege, Faperj, 2008. p. 401-410. 
Agronegócio e Logística em Áreas de Cerrado: expressão da agricultura científica globalizada. Revista da ANPEGE. v. 3, p. 33-43, 2007. Disponível em: <http://www.revista_anpege.ig.ufu.br/include/getdoc.php?id=18>. Acesso em: 20 mar. 2014.

Transporte e logística de granéis sólidos agrícolas: componentes estruturais do novo sistema de movimientos do território brasileiro. Investigaciones Geográficas, Boletín del Instituto de Geografía, UNAM, ISSN 0188-4611, Núm. 55, 2004, pp. 79-96. Disponível em: <http://www.revistas.unam.mx/index.php/rig/article/ view/30112>. Acesso em: 08 set. 2013.

Confederação Nacional da Agropecuária (CNA); Confederação Nacional da Indústria (CNI); Macrologística. Projeto Centro-Oeste Competitivo. 2013. Disponível em: $<$ http://www.sincti.com/clientes/ampa/arquivos/publicacoes/ 19122013032704.pdf $>$. Acesso em: 25 jul. 2014.

CONTEL, Fábio Betioli. Os sistemas de movimento do território brasileiro. In: SANTOS, Milton; SILVEIRA, Maria Laura. O Brasil: território e sociedade no início do século XXI. 6. Ed. Rio de Janeiro: Record, 2004. p. 357-374.

CORRÊA, Roberto Lobato. Interações espaciais. In: CASTRO, Iná Elias de; GOMES, Paulo César da Costa; CORRÊA, Roberto Lobato. (Org.). Explorações geográficas: percursos no fim do século. Rio de Janeiro: Bertrand Brasil, 1997.

COSTA, Wanderley Messias da. O Estado e as políticas territoriais no Brasil. 9. ed. São Paulo: Contexto, 2000.

DAMIANI, Amélia Luisa. Urbanização crítica e situação geográfica a partir da metrópole de São Paulo. In: CARLOS, Ana Fani Alessandri; OLIVEIRA, Ariovaldo Umbelino de (Org.). Geografias de São Paulo; representação e crise da Metrópole. São Paulo: Contexto, 2004. p. $19-58$.

DELGADO, Nelson Giordano. Política econômica, ajuste externo e agricultura. In: LEITE, Sérgio. Políticas públicas e agricultura no Brasil. Porto Alegre: Editora da UFRGS, 2001.

DINIZ, Clélio Campolina. Dinâmica regional e ordenamento do território brasileiro: desafios e oportunidades. Belo Horizonte: UFMG/CEDEPLAR, 2013. 29 p. (Texto para discussão $\mathrm{n}^{\circ}$ 471). Disponível em: <http://www.cedeplar.ufmg.br/ pesquisas/td/ TD\%20471.pdf>. Acesso em: 02 mar. 2015.

DUARTE, Aluízio Capdeville. O Centro-Oeste na organização regional do Brasil. In: IBGE. Geografia do Brasil. Região Centro-Oeste. Rio de Janeiro: IBGE, 1988a. p.15-20.

. Estrutura do Espaço Regional. In: IBGE. Geografia do Brasil. Região Centro-Oeste. Rio de Janeiro: IBGE, 1988b. p. 243-267.

ELIAS, Denise. Regiões produtivas do agronegócio: notas teóricas e metodológicas. In: BERNARDES, Julia A.; SILVA, Catia A.; ARRUZZO, Roberta C. (Org.). Espaço e energia: mudanças no paradigma sucroenergético. Rio de Janeiro: Lamparina, 2013. 220p. 
Agronegócio e novas regionalizações no Brasil. Revista Brasileira de Estudos Urbanos e Regionais. (ANPUR), 2011, v. 13, n. 2, p. 153-167, 2011. Disponível em: <http://www.anpur.org.br/revista/rbeur/index.php/rbeur/article/view/ 400/376>. Acesso em: 09 set. 2013.

Globalização e agricultura: a região de Ribeirão Preto-SP. São Paulo: Editora da Universidade de São Paulo, 2003.

FAUSTO, Boris. História concisa do Brasil. São Paulo: Edusp, 2000.

Federação da Agricultura e Pecuária do Estado de Mato Grosso (FAMATO); Serviço Nacional de Aprendizagem Rural no Estado de Mato Grosso (SENAR-MT); Serviço Nacional de Aprendizagem em Cooperativismo no Estado de Mato Grosso (SESCOOP-MT). Diagnóstico da cadeia produtiva do leite no Estado de Mato Grosso: relatório de pesquisa. Cuiabá: FAMATO, 2011. 93 p. Disponível em: < http://www.imea.com.br/ upload/pdf/arquivos/Microsoft_Word_Diagnostico_da_Cadeia_do_Leite_MT_Final_pdf $>$.

Acesso em: 23 maio 2014.

FELIPE JUNIOR, Nelson Fernandes. Sistema hidroviário interior e intermodalidade no estado de São Paulo: a hidrovia Tietê-Paraná. In: SILVEIRA, Márcio Rogério (Org.). Circulação, transportes e logísticas: diferentes perspectivas. São Paulo: Outras Expressões, 2011. cap. 18 , p. 515-552.

FERNANDES, Bernardo Mançano; WELCH, Clifford Andrew. Campesinato e agronegócio da laranja nos EUA e Brasil. In: FERNANDES, Bernardo Mançano (Org.). Campesinato e agronegócio na América Latina: a questão agrária atual. São Paulo: Expressão Popular, 2008. 432p.

FERREIRA, Cândido Guerra. O Fordismo, sua Crise e o Caso Brasileiro. Cadernos do Cesit, v. 13, p. 1-28, 1993. Disponível em: <http://www.eco.unicamp.br/cesit/images/ stories/13CadernosdoCESIT.pdf>. Acesso em: 30 mar. 2014.

FIRKOWSKI, Olga L. C. de Freitas; SPOSITO, Eliseu Savério. (Org). Indústria, ordenamento e território: a contribuição de André Fischer. São Paulo: Expressão Popular, 2008.

FORTUNA, Denizart da Silva. Circulação e territorialidade econômica: o (re)ordenamento territorial no eixo médio mato-grossense da BR-163 (Cuiabá-Santarém). 2006. 251 f. Tese (Doutorado em Geografia) - Instituto de Geociências, Universidade Federal do Rio de Janeiro, Rio de Janeiro, 2006.

FREDERICO, Samuel. Região e modernização agrícola. In: BERNARDES, Julia A.; SILVA, Catia A.; ARRUZZO, Roberta C. (Org.). Espaço e energia: mudanças no paradigma sucroenergético. Rio de Janeiro: Lamparina, 2013. 220p.

GALlARDO, Alfonso P. et al. Avaliação da Capacidade de Infra-estrutura de Armazenagem para os Granéis Agrícolas Produzidos no Centro Oeste Brasileiro, 2010. Disponível em: 〈http://www.ipen.org.br/downloads/XXI/166_P_Gallardo_Alfonso.pdf>. Acesso em: 11 maio 2014. 
GIDDENS, Anthony. O mundo na era da globalização. 6. ed. Lisboa: Editorial Presença, 2006.

GOLDENSTEIN, Lea; SEABRA, M. Divisão regional do trabalho e nova regionalização. Revista do Departamento de Geografia. Departamento de Geografia. n. 1 São Paulo: USP/FFLCH, 1982, P. 21-47. Disponível em: <http://citrus.uspnet.usp.br/rdg/ojs/index.php/ rdg/article/view/292/272>. Acesso em: 15 abr. 2014.

HARVEY, David. O enigma do capital: e as crises do capitalismo. São Paulo: Boitempo, 2011. 235p.

$251 \mathrm{p}$.

. A produção capitalista do espaço. 2. ed. São Paulo: Annablume, 2006.

O novo imperialismo. São Paulo: Edições Loyola, 2004. 201p.

Condição pós-moderna: uma pesquisa sobre as origens da mudança cultural. 6. ed. São Paulo: Edições Loyola, 1996.

HAESBAERT, Rogério; LIMONAD, Ester. O território em tempos de globalização. Revista Eletrônica de Ciências Sociais Aplicadas. 2007, $\mathrm{n}^{\circ} 2$ (4), vol. 1. Disponível em: <http://www.uff.br/etc/UPLOADs/etc\%202007_2_4.pdf >. Acesso em: 12 out. 2013.

HESSE, Markus; RODRIGUE, Jean-Paul. The transport geography of logistics and freight distribution. Journal of Transport Geography, v. 12, p. 171-184, set. 2004. Disponível em: $<$ http://elogistics.lhu.edu.tw/may/course/93_2/c_auto/\%E5\%95\%86\%

E6\%A5\%AD\%E8\%87\%AA\%E5\%8B\%95\%E5\%8C\%96\%E5\%A0\%B1\%E5\%91\%8A/46\%E 5\%95\%86\%E6\%A5\%AD\%E8\%87\%AA\%E5\%8B\%95\%E5\%8C\%96/05030715545508659(4 6).pdf>. Acesso em: 14 abr. 2015.

HONE, Angus. The primary commodities boom. In: New Left Review I. N ${ }^{\circ}$. 81, septemberoctober, 1973. Disponível em: <http://newleftreview.org/static/assets/ archive/pdf/ NLR08004.pdf> . Acesso em: 02 fev. 2015.

HUERTAS, Daniel Monteiro. Dinâmicas territoriais dos eixos nodais que comandam a logística rodoviária do agronegócio no Centro-Oeste brasileiro. - DOI 10.5216/ag.v8i2.29642. Ateliê Geográfico, [S.1.], v. 8, n. 2, p. 38-64, ago. 2014. ISSN 19821956. Disponível em: <http://revistas.ufg.br/index.php/atelie/article/view/ 29642/17132>. Acesso em: 19 fev. 2015. doi:10.5216/ag.v8i2.29642.

IANNI, Octavio. Nação: província da sociedade global? In: SANTOS. Milton. SOUZA, Maria. A. de; SILVEIRA. Maria. L. (Org.). Território: globalização e fragmentação. 4. ed. São Paulo: Hucitec. Anpur, 1998. 332p., p. 77-84.

INSTITUTO BRASILEIRO DE GEOGRAFIA E ESTATÍSTICA. Levantamento Sistemático da Produção Agrícola: Pesquisa Mensal de Previsão e Acompanhamento das Safras Agrícolas no Ano Civil. IBGE: Rio de Janeiro, v.27, n.8, p.1-85, agosto, 2014a. Disponível em: <ftp://ftp.ibge.gov.br/Producao_Agricola/Levantamento_Sistematico_da_ Producao_Agricola_[mensal]/Fasciculo/lspa_201408.pdf>. Acesso em: 11 jun. 2014. 
Produto interno bruto dos municípios de 1999 a 2012, IBGE: Rio de Janeiro, 2014b. Disponível em: <http://www.cidades.ibge.gov.br/comparamun/compara. php?lang $=\&$ coduf $=51 \&$ idtema $=134 \& \operatorname{codv}=\mathrm{v} 05 \&$ search $=$ mato-grosso|acorizal $\mid$ sintese-dasinformacoes-2012>. Acesso em: 11 maio 2015.

. Estimativa da população 2014: Diretoria de pesquisas, Coordenação de população e indicadores sociais. IBGE: Rio de Janeiro, 2014c. Disponível em: <http://www.cidades.ibge.gov.br/comparamun/compara.php?lang=\&coduf=51\&idtema $=130 \& \operatorname{codv}=\mathrm{v} 01 \&$ search=mato-grosso|acorizal|sintese-das-informacoes- $>$. Acesso em: 30 jun. 2015.

Pesquisa Industrial Anual - Produto 2011: Diretoria de Pesquisas, Coordenação de Indústria. IBGE: Rio de Janeiro, v. 30, n.2, p.1-188, 2011. Disponível em: <http://www.ibge.gov.br/home/estatistica/economia/industria/pia/produtos/produto 2011/defaultproduto.shtm>. Acesso em: 20 maio 2014.

. Pesquisa de orçamentos familiares 2008-2009: despesas, rendimentos e condições de vida. IBGE: Rio de Janeiro, 2010. Disponível em: <http://www.ibge. gov.br/home/estatistica/populacao/condicaodevida/pof/2008_2009/POFpublicacao.pdf>.

Acesso em: 01 jul. 2015.

Instituto Mato-Grossense de Economia Agropecuária (IMEA). Boletim semanal de Bovinocultura. $\mathrm{N}^{\text {o } 337 . ~} 23$ de janeiro de 2015. Cuiabá: IMEA, 2015a. Disponível em: $<$ http://www.imea.com.br/upload/publicacoes/arquivos/2015_01_23_BSBoi.pdf $>$. Acesso em: 18 maio 2015.

- Boletim semanal da soja. $\mathrm{N}^{\text {o } 335.9}$ de janeiro de 2015. Cuiabá: IMEA, 2015b. Disponível em: <http://www.imea.com.br/upload/publicacoes/arquivos/

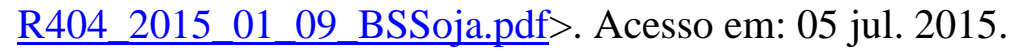

- Boletim semanal do milho. $\mathrm{N}^{\mathrm{o}} 335.9$ de janeiro de 2015. Cuiabá: IMEA, 2015c. Disponível em: < http://www.imea.com.br/upload/publicacoes/ arquivos/R403_2015_01_09_BSMilho.pdf>. Acesso em: 05 jul 2015.

IMEA, 2014.

. Safra de soja - produção: estimativa da safra 2013-2014. Cuiabá:

LACERDA, Sander Magalhães. Logística ferroviária do Porto de Santos: a integração operacional da infraestrutura compartilhada. Revista do BNDES. Rio de Janeiro, v. 12, n. 24, p. 189-210, dez. 2005. Disponível em: <http://www.bndespar.gov.br/ SiteBNDES/export/sites/default/bndes_pt/Galerias/Arquivos/conhecimento/revista/rev2407.p df >. Acesso em: 17 jul. 2015.

LEÃO, Danúbia da; EL HAGE, Pedro Paulo Fernandes; BAMPI, Aumeri Carlos. A sociedade civil de Cáceres-MT no monitoramento da hidrovia Paraguai-Paraná (HPP) no Pantanal matogrossense. Revista GeoPantanal, Corumbá, v. 8, n. 14, p. 46-66, jan./jun.. 2013. Disponível em: <http://seer.ufms.br/index.php/revgeo/article/view/104/ 121>. Acesso em: 09 jun. 2015.

LEFEBVRE, Henri. Espaço e política. Belo Horizonte: Editora UFMG, 2008. 
brasileira, 1991.

Lógica formal/lógica dialética. 5. Ed. Rio de Janeiro: Civilização

LENCIONI, Sandra. Agricultura e urbanização: a intensificação do Capital no Campo e a Nova Relação Rural Urbano no Estado de São Paulo. Revista do Departamento de Geografia. São Paulo, n. 4, p.41-51, 1985.

LIPIETZ, Alain. Miragens e milagres: problemas da industrialização no Terceiro Mundo. São Paulo: Nobel, 1988.

MACEDO, Fernando Cezar de; ANGELIS, Ângelo de. Guerra fiscal dos portos e desenvolvimento regional no Brasil. Redes - Rev. Des. Regional, Santa Cruz do Sul, v. 18, n. 1, p. 185-212, jan/abril 2013. Disponível em: <https://online.unisc.br/ seer/index.php/redes/article/view/2909/2520>. Acesso em: 09 mar. 2015.

MANDEL, Ernest. O capitalismo tardio. São Paulo: Abril Cultural, 1982. 417p.

MARTINS, José de Souza. O sujeito oculto: ordem e transgressão na reforma agrária. Porto Alegre: Editora da UFRGS, 2003.

Paulo: Hucitec, 1997.

Fronteira: a degradação do Outro nos confins do humano. São

MARX, Karl. Contribuição à crítica da economia política. 2.ed. São Paulo: Expressão Popular, 2008.

MATO GROSSO. Decreto $n^{\circ} 185$, de 09 de julho de 2015. Dispõe sobre a designação de rodovias estaduais para cobrança de pedágio, nos termos do art. $1^{\circ}$ da Lei $n .{ }^{\circ} 8.620$, de 28 de dezembro de 2006, e dá outras providências. Diário Oficial do Estado de Mato Grosso, Cuiabá, 09 de jul. 2015. p. 3. Disponível em: <https://www.iomat.mt.gov. br/portal/visualizacoes/jornal/\#/p:2/e:14125?find=DECRETO185>. Acesso em: 23 jul. 2015.

- Secretaria de Estado de Fazenda. Balanço Geral do Estado. Relatório Circunstanciado sobre as Contas. Volume 1, Exercício de 2013. Cuiabá. 2014. Disponível em: $\quad<$ http://www.sefaz.mt.gov.br/portal/Financeiro/ ContGovernamental/BalancoGeral/VOLUME_I_Relatorio_Circunstanciado_sobre_as_Contas -2013_v11042014_as_17-20_DIGITAL.pdf>. Acesso em: 17 jul. 2014.

Secretaria de Estado de Fazenda. Balanço Geral do Estado. Relatório Circunstanciado sobre as Contas. Volume 1, Exercício de 2012. Cuiabá. 2013a. Disponível em: 〈http://www.auditoria.mt.gov.br/download.php? id=255126>. Acesso em: 15 jul. 2014

Secretaria de Estado de Planejamento e Coordenação. SEPLAN. Informativo municipal de Mato Grosso - 2014. Cuiabá, 2013b. Disponível em: $<$ http://www.dados.mt.gov.br/publicacoes/informativos/municipal/ 2014/\#14/z > . Acesso em: 25 jul. 2014.

Tribunal de Contas de Mato Grosso. Relatório de Auditoria dos Incentivos Fiscais Concedidos pelo Governo do Estado de Mato Grosso. 2009. Disponível 
em: <http://www.tce.mt.gov.br/arquivos/downloads/ 00015670/Relatorio_ Incentivos_Fiscais.pdf $>$. Acesso em: 15 jul. 2014.

MÉSZÁROS, István. Para além do capital: rumo a uma teoria da transição. 1.ed. São Paulo: Boitempo, 2011.

MONTEIRO, Jorge Luiz Gomes. A reestruturação produtiva e a agroindústria do etanol em Mato Grosso. In. Anais do I Seminário Nacional - Reestruturação no setor sucroenergético brasileiro: novas e velhas espacialidades. Rio de Janeiro, 2012. v. 1. p. 2031.

Mudanças Espaciais Induzidas pelo Progresso Técnico: a realidade da agricultura matogrossense. 2004. 317 f. Tese (Doutorado em Geografia) - Instituto de Geociências, Universidade Federal do Rio de Janeiro, Rio de Janeiro, 2004.

MOREIRA, Ruy. Formação espacial brasileira: uma contribuição crítica à Geografia do Brasil. Rio de Janeiro: Consequência, 2012.

Movimento Pró-Logística. Estradeiro: expedição Santo Antônio das Lendas. S/L, 2013. Disponível em: <http://www.sincti.com/clientes/ampa/arquivos/pro_logistica/ 25072013121441.pdf $>$. Acesso em: 17 maio 2015.

NEGRI, Sérgio Sebastião. Modernização agrícola e reorganização do espaço agrário da mesorregião sudeste mato-grossense. 2001. 177 f. Dissertação (Mestrado em Geografia) Instituto de Geografia, Universidade Federal de Uberlândia, Uberlândia, 2001.

NEGRI, Silvio Moisés. O processo de segregação sócio-espacial no contexto do desenvolvimento econômico da cidade de Rondonópolis-MT. 2008. 195 f. Tese (Doutorado em Geografia) - Instituto de Geociências e Ciências Exatas, Universidade Estadual Paulista, Rio Claro, 2008.

OLIVEIRA, Ariovaldo U. de. Modo de Produção Capitalista, Agricultura e Reforma Agrária. São Paulo: FFLCH, 2007.

BR-163 Cuiabá-Santarém: geopolítica, grilagem, violência e mundialização. In: TORRES, Maurício (Org.). Amazônia revelada: os descaminhos ao longo da BR-163. Brasília: CNPQ, 2005. 496p. cap. 2, p. 67-183.

PASIN, Jorge Antonio Bozoti. A logística de exportação da soja em grãos de Mato Grosso. Revista do BNDES. Vol. 14, n. 27. Rio de Janeiro. Jun. 2007, p. 195-212. Disponível em: <http://www.bndes.gov.br/SiteBNDES/export/sites/ default/bndes_pt/ Galerias/Arquivos/conhecimento/revista/rev2708.pdf>. Acesso em: 20 mar. 2014.

PENNA, Nelba Azevedo. Empreendedorismo e planejamento urbano em Brasília: da máquina de morar à máquina de crescimento urbano. In: PEREIRA, Elson Manoel (Org.). Planejamento urbano no Brasil: conceitos, diálogos e práticas. 2. Ed. Chapecó: Argos, 2013. 325 p., p. 207-230.

PESSÔA, Vera Lúcia Salazar. Ação do Estado e as transformações agrárias no cerrado das zonas de Paracatu e Alto Paranaíba-MG. 1988. 251 f. Tese (Doutorado em Geografia) 
- Instituto de Geociências e Ciências Exatas, Universidade Estadual Paulista, Rio Claro, 1988.

PEIXINHO, Dimas Moraes. A dinâmica sócio-espacial do modelo técnico-produtivo da sojicultora no Cerrado e a formação de centros dinâmicos: o caso de Rondonópolis (MT) e Rio Verde (GO). 2006. 179 f. Tese (Doutorado em Geografia) - Instituto de Geociências, Universidade Federal do Rio de Janeiro, Rio de Janeiro, 2006.

PIRES, Mauro Oliveira. Programas agrícolas na ocupação do cerrado. Sociedade e cultura. Revista de ciências sociais. Vol. 3, n. 1 e 2. Goiânia: FCHF-UFG, 2000, p.111-131.

PIVA, Luiz Guilherme. Plano Plurianual - PPA 2000-2003: principais aspectos. Brasília: Câmara dos Deputados/Assessoria Técnica, out. 1999. Disponível em: <file:///C:/Users/usuario/Downloads/resumoPPA.pdf> . Acesso em: 06 maio 2014.

PORTO DE SANTOS. Operadores portuários. 2015. Disponível em: <http://www.portodesantos.com.br/operadores.php>. Acesso em: 31 jul. 2015.

PORTO-GONÇALVES, Carlos Walter. A globalização da natureza e a natureza da globalização. 2. ed. Rio de Janeiro: Civilização Brasileira, 2011. 461p.

POULANTZAS, Nicos. O Estado, o poder, o socialismo. 4. Ed. São Paulo: Paz e Terra, 2000. 272p.

PRESSINOTT, Fernanda. Obras emergenciais liberam tráfego de caminhões de soja na BR163. Valor Econômico. 28 de fevereiro de 2014. Disponível em: <http://www. valor.com.br/agro/3447544/obras-emergenciais-liberam-trafego-de-caminhoes-de-soja-na-br163>. Acesso em: 28 fev. 2014.

RAFFESTIN, Claude. Por uma Geografia do Poder. São Paulo: Ática, 1993.

RIBEIRO, Ivo; PUPO, Fábio. Governo recebe projeto da Ferrogrão. Valor Econômico. 7 de fevereiro de 2014. Disponível em: 〈http://www.valor.com.br/ empresas/3422536/governorecebe-projeto-da-ferrograo $>$. Acesso em: 07 fev. 2014.

ROCHA NETO, João Mendes. O território no Plano Nacional de Logística e Transportes. In: STEINBERGER, Marília. (Org.). Território, Estado e políticas públicas espaciais. Brasília: Ler Editora, 2013.

RONDINELLI, Dennis; BERRY, Michael. Multimodal Transportation, Logistics, and the Environment: Managing Interactions in a Global Economy. European Management Journal, v. 18, n. 4, p. 398-410, ago. 2000. Disponível em: < http://ebc.ie.nthu.edu.tw/km/MI/hou/LM_Reference/P45.pdf>. Acesso em: 15 abr. 2015.

ROSSINI, Rosa Ester. A produção do novo espaço rural: pressupostos gerais para a compreensão dos conflitos sociais no campo. In: SOUZA, Maria Adélia de; SANTOS, Milton. (Org.). A construção do espaço. São Paulo: Nobel, 1986.

RUMO ALL. Sala de imprensa. Press releases. ALL obtém licenças ambientais para finalizar duplicação da ferrovia. 2014. Disponível em: <http://pt.all- 
$\underline{\text { logistica.com/all/web/conteudo_pti.asp?idioma }=0 \& \text { conta }=45 \& \text { tipo }=27244 \& i d=189988>}$. Acesso em: 13 jul. 2015.

SANTOS, Milton. Metamorfoses do espaço habitado: fundamentos teóricos e metodológicos da Geografia. 6. Ed. São Paulo: Editora da Universidade de São Paulo, 2012.

A natureza do espaço: técnica e tempo, razão e emoção. 4. ed. São Paulo: Editora da Universidade de São Paulo, 2008a.

São Paulo, 2008b.

A urbanização brasileira. 5. Ed. São Paulo: Editora da Universidade de

Por uma outra globalização: do pensamento único à consciência universal.

11. ed. Rio de Janeiro: Record, 2004.

O Papel ativo da geografia: um manifesto. Revista território. Rio de Janeiro. Ano v. no 9, pp.103-109. 2000. Publicado por ocasião do XII Encontro Nacional de Geógrafos. Florianópolis. Julho de 2000.

O espaço do cidadão. São Paulo: Editora Nobel, 1993.

SANTOS, Milton; SILVEIRA, Maria Laura. O Brasil: território e sociedade no início do século XXI. 6. ed. Rio de Janeiro: Record, 2004.

SEABRA, Odette Carvalho de Lima. Metropolização: a reprodução do urbano na crise da sociedade do trabalho. Cidades. Presidente Prudente: Grupo de Estudos Urbanos, v. 6, n. 10, 2009.

SILVA, Silvana Cristina da. A criação de municípios no front e a formação da elite do agronegócio: faces do uso do território brasileiro, Geosul, Florianópolis, v. 24, n. 48, p 85101, jul./dez. 2009. Disponível em: <https://periodicos.ufsc.br/index. php/geosul/article/view/2177-5230.2009v24n48p 85/12283>. Acesso em: 03 set. 2013.

SILVA, Carlos A. Franco da. Fronteira agrícola capitalista e ordenamento territorial. In: SANTOS, Milton; BECKER, Berta K. (Org.). Território, territórios: ensaios sobre o ordenamento territorial. 3. ed. Rio de Janeiro: Lamparina, 2007. cap. 13, p. 282-312.

Cuiabá: Entrelinhas, 2003.

Grupo André Maggi: corporação e rede em áreas de fronteira.

SILVEIRA, Márcio Rogério. Infraestruturas e logística de transportes no processo de integração econômica e territorial. Mercator (Fortaleza. Online), v. 12, p. 41-53, 2013. Disponível em: <http://www.mercator.ufc.br/index.php /mercator/article/view/1169/ 495>. Acesso em: 11 mar. 2014.

Geografia da Circulação, Transportes e Logística: construção epistemológica e perspectivas. In: SILVEIRA, Márcio Rogério (Org.). Circulação, transportes e logísticas: diferentes perspectivas. São Paulo: Outras Expressões, 2011 a. 624p., cap. 1, p. 21-68. 
SILVEIRA, Maria Laura. Território usado: dinâmicas de especialização, dinâmicas de diversidade. Ciência Geográfica. Bauru. XV. Vol. XV (1) Janeiro/Dezembro. p. 4-12, 2011 b.

SMITH, N. Desenvolvimento desigual: natureza, capital e a produção do espaço. Rio de Janeiro: Bertrand Brasil, 1988.

SODRÉ, Márcio. Sitiantes protestam em pedágio na MT-130. A tribuna. 18 de fevereiro de 2014. Disponível em: <http://www.atribunamt.com.br/2014/02/ sitiantes-protestam-empedagio-na-mt-130/>. Acesso em: 19 jun. 2014.

SOJA, Edward W. Geografias pós-modernas: a reafirmação do espaço na teoria social crítica. Rio de Janeiro: Jorge Zahar Ed., 1993. 324p.

SOUZA, Adauto de Oliveira. A política de transporte no governo Fernando Henrique Cardoso: o exemplo do modal ferroviário no Estado de Mato Grosso do Sul. In: SILVEIRA, Márcio Rogério (Org.). Circulação, transportes e logísticas: diferentes perspectivas. São Paulo: Outras Expressões, 2011. 624p. cap. 14, p. 403-426.

STORPER, Michael. Industrialization, Economic Development and the Regional Question in the Third World: from Import Substitution to Flexible Production. London: Pion, 1991.

SUZUKI, Júlio César. Modernização, território e relação campo-cidade: uma outra leitura da modernização da agricultura. Revista Agrária. São Paulo, n. 6, p.83-95, 2007.

TANGARÁ DA SERRA, Lei No 3.445, de 27 de outubro de 2010. dispõe sobre incentivos fiscais e econômicos para empresas industriais, comerciais e prestadoras de serviços no âmbito do município de Tangará da Serra, revoga a lei $\mathrm{n}^{\circ} 2.168$ de 23 de junho de 2004 e suas alterações, lei $\mathrm{n}^{\mathrm{o}} 2.371$ de 12 de agosto de 2005 e lei $\mathrm{n}^{\mathrm{o}} 2.424$ de 08 de novembro de 2005 , e dá outras providências. Disponível em: <http://www.tangaradaserra.mt.gov.br/Leis/>. Acesso em: 23 jul. 2014.

TAYLOR, Peter J; FLINT, Colin. Geografía Política: Economía-mundo, Estado-Nación y Localidad. Madri: Trama, 2002.

THÉRY, Hervé. Rede global/rede local ou como a geografia pode servir, também, para defender uma auto-estrada. In: BECKER, Bertha K.; MIRANDA, Mariana. (Org.). A geografia política do desenvolvimento sustentável. Rio de Janeiro: Editora da UFRJ, 1997. 496p., p. 185-205.

TOLEDO, Marcio. Especialização regional produtiva e a viabilização do território nacional para o escoamento da soja. Mercator (Fortaleza. Online), v. 6, $\mathrm{n}^{\mathrm{o}}$ 12, p. 7-16, 2007. Disponível em: 〈http://www.mercator.ufc.br/index.php/mercator/article/view/ 42/16 >. Acesso em: 08 set. 2013.

TONIN, Danielly. Juíza suspende cobrança de pedágio em Rondonópolis. A Tribuna. 26 de março de 2014. Disponível em: <http://www.atribunamt.com.br/2014/03/juiza-suspendecobranca-de-pedagio-em-rondonopolis/>. Acesso em: 19 jun. 2014. 
TORRES, Maurício. Fronteira, um eco sem fim: considerações sobre a ausência do Estado e exclusão social nos municípios paraenses do eixo da BR-163. In: TORRES, Maurício (Org.). Amazônia revelada: os descaminhos ao longo da BR-163. Brasília: CNPQ, 2005. 496p. cap. 6, p. 271-319.

VENCOVSKY, Vitor Pires; CASTILLO, Ricardo. Sistema ferroviário pós-privatização e fluidez corporativa: o movimento de produtos agrícolas no território brasileiro, GEOUSP Espaço e Tempo, São Paulo, $\mathrm{N}^{\mathrm{o}}$ 21, pp. 119 - 134, 2007. Disponível em: 〈http://www.geografia.fflch.usp.br/publicacoes/ Geousp/Geousp21/Artigo_Vitor.pdf $>$. Acesso em: 02 set. 2013.

VESENTINI, José William. A capital da geopolítica. São Paulo: Ática, 1986.

WWF-Brasil. O que fazemos? Redução de impactos. Ecologia da paisagem. Hidrelétricas Tapajós. 2015. Disponível em: <http://www.wwf.org.br/natureza brasileira/reducao_de_impactos2/lep/tapajos/>. Acesso em: 18 jun. 2015. 


\section{APÊNDICE}

\section{Lista de pessoas entrevistadas}

Márcio Augusto Martines - Gerente do Terminal Ferroviário Rumo ALL em Rondonópolis Entrevistado em 30 de julho de 2015.

Miguel Mendes - Diretor da Associação dos Transportadores de Cargas - Entrevistado em 06 de maio de 2015. 